










\title{
Eatalogue
}

\author{
OF THE
}

\section{LEVERIAN MUSEUM,}

PART I.

INCLUDING THE FIRST EICHT DAYS SALE,

* the remaining parts wili be published with al, POSSIBLE SPEED.

$$
\text { THE } S A L E
$$

\section{THE ENTIRE COLLECTION}

\author{
(By Messrs. KING and LOCHEE,
}

WILL COMMENCE

On Monday, the 5th of MAY, 1806, at Twelve o'Clock, In the Building now occupied ly

\section{THE MUSEUIT.}

Catalogubs to be had (price $1 s$. ) at the Place of Sale; as Messrs. King and Lochèe's, (the Auctioneers) and at Heyden's Printing-Office, Brydges-Street, Covent-Garden. 


\section{CONDITIONS OF SALE.}

I. THE highest Bidder will be declared the Buyer; but if any Dispute should arise, the Lot must be put up again.

II. No Advance less than Sixpence; above One Pound, One Shilling; above Five Pounds, Five ShilLINGS.

III. Every Purchaser is to pay down Five Shillings in the Pound, as Earnest, in Part of Payment, and to give in his Name and Place of Abode, if required.

IV. The Lots to be removed, at the Expence of the Purchasers, within one Day after the Sale; and the Remainder of the Purchase-Money to be paid on or before the Delivery.

V. Upon Failure of complying with the above Conditions, the Money deposited in Part of Payment shall be forfeited. All Lots uncleared within the Time aforesaid, shall be re-sold, oy public or private Sale; and the Deficiency (if any) attending such Re-sale, shall be made good by the Defaulters at this Sale.

Gentlemen who cannot attend the Sale, may have their Commissions faithfully executed, by their humble Servants,

King and Lochée.

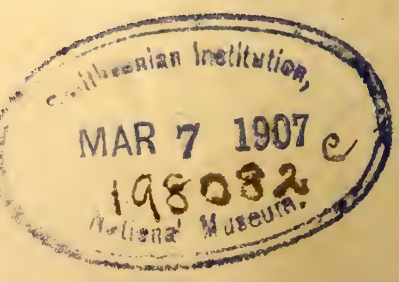




\section{CATALOGUE}

\section{O F \\ Ihe 乣everian \$guseum.}

\section{FIRST DAY.}

Monday the 5th of May, 1806.

$1 \mathbb{E}$ LEGANT stellated malachite, Banuatt, yellow Sweedish copper, and native copper, with crystallised vitreous octoedral crystals, Cornwall

2 Four large specimens of calcareous spars in nodules of ketton stone

3 A handsome piece of crystallised Piedra d' Ynca, China ; brilliant bubbled marcasite, and two more

4 Seven pieces of quartz and rock crystal, one chrystal very clear, and enclosing hair-like actinolite

5 A specimen of tremolite, black shorl in quartz, Arragon; black shorl in mica, and three others

6 A fine specimen of hæmatite, having a bubbled, and stalactical surface

7 Rose-coloured calcareous deposition, tinged by cobalt; and singularly variegated brown ditto, from Hesse

8 Native cinnaber, Idria; copper-nickel, and another

9 A fine group of pearl-spar, Hungary.

10 Stalactical iron, Triers

11 Tremolite, finely crystallised, Switzerland; and green malachite copper ore on quartz, with topazine srystal 
12 Jasphactes, Oberstein; fortification, agate, ditto; and two more

13 Eight specimens of quartz, one a clear crystal, having hairlike internal appearances

14 Solen Siliqua, with the animal in spirit

15 Dark green phosphate of lead, crystallised; and apple-green bubbled ditto, Saxony

16 Cinnabar with running quicksilver, Idria; and a fine specimen of pink and yellow arseniate of cobalt, Hesse

17 A very fine specimen of cristallised manganese, Ilefield

18 Two large opposite valves of the chama gigas, or gigantic cockle, Borneo

19 Duck's foot scallop, (Ostrea nodosa Linn) W. Indies; and a wrinkled ear, (Haliotis Midœ Linn) Cape of Good Hope

20 The scarlet spotted mulberry, the violet mouth porcupine, the tuberculated scoop, 2 pyrae, and an endive triplep

21 A large nautilus pompilius China

22 A spotted tun, a large shagreened trochus, a scarce sun, and an oriental helmet

23 Anthropormorphitæ, 6 specirnens

24 Fossil nautilus, Sheppy Island

25 Antigua fossilwood, a large specimen

26 Anthropormorphitæ, 4 specimens

27 Fossil plants, 5 specimens

28 Fossil plants, 6 specimens

29 Impression of a fish, fossil

30 Fossil plants, 7 various specimens

31 A polished slab of marble, with fragments of encrini, Derbyshire

32 Impression of bark in coal slate

33 Fossil jawbone, from Tame, Oxfordshire

34. Three specimens of fossil plants

35 Singular fossil tooth of some animal unknown

26 A specimen of fossil plant

37 Two specimens of fossil plants

38 Nautilus, Sheppy Island, large and fine

39 Stone with several fragments of echini, Stonsfield

40 Fossil tortoise, very rare, from Sheppy Island

41 A mass of Dudley fossils

1.2 Impressions of a verticillated plant in coal slate

43 Fossil plant in coal slate

14. Rose-hill Parrot, Botany Bay, Psittacus eximius

45 Long-tail'd red-shouldered Finch, without case, Emberixa imperialis

46 Pelican, South Seas

47 Largest Auk, Alca impennis

48 Crossbill, Lozio curvirostra

49 Tantalus falcinellus, Russia

50 Blue and yellow Maccaw, without case, Pissitacus ararauna 
51 Anas spectabilis, king duck, America

52 Pipra rupicola, cock of the rock, male, South America

53 Toucan, Rhamphastos tucanxs

54 Green Dove (one specimen) E. Indies

55 Red-shouldered Starling, Oriolus phøniceus

56 Pileated Woodpecker, Picus pileatus

57 Great horned Owl, Strix bubo

58 Velvet Shag, Greenland-rare

59 Tetrun tetrix, black Grous

60 Skua Gull, Larus cataractes

61 Barred Owl, Strix ncbulosa, Hudson's Bay

62 Blue-bellied Parrot, Pissitacus hematodus

63 Baltimore Oriole, male and female, Oriolus Baltimore, Linn.

64 Alexandrine Parrot, male and female, Pissitacus Alexandri

65 Scarlet and green Maccaw, Psittacus Macao

66 Java Grosbeak, Loxia Oryzivora, East Indies

67 American Jay-Corvus cristatus

68 Armadillo-Dasypus novem-cinctus

69 Opossum-Didelphis Virginiana

70 Angora Cat-Felis catus, var. Ang.

71 Sloth, male-Bradypus didactylus

72 Siberian Hare

73 Lamb, var.

74 Fox, common-Canis vulpes

75 Fulimart-Mustela putorius

76 Maucauco, ont of case-Lemur Catta

77 Two large horse shoes, 1 , and 2 of the former catalogue

78 Three horse shoes, 3, 4, 7, of ditto

79 Moorish bridle and spurs

80 Powder horn curiously carved by the Indians

81 Stake, No. 17 in the entry

82 Barbary stirrups and bridle

83 A representation of three engravings in plaster composition

85 Carving in ivory, representing the hunting of the wild boar, an elaborate and interesting article

85 Three horse shoes, No. 5, 8, 9 of former catalogue

86 Truncheon No. 2 of ditto

87 Four basso relievo heads, namely Linnæus, Edwards, Sir Ashton Lever, and Thomas Pennant, Esq.

88 Card paper curiously cut, a flower piece

89 Two Chinese tinder boxes

90 Three oriental pipes

91 Paper curiously cut in imitation of lace

92 Curious specimen of penmanship, by a boy ten years of age

93 Fan made of bird's feathers, Brasil

94 Two specimens of Swedish money, viz. dollar and half dollar.

95 Turkish Hooker

96 Hammock made of grass from the Spanish main 
97 Legatto bark worked to resemble lace

98 Heads of six of the Crsars, curiously turned in wood

99 Fiv elegant cuitings in paper, flowers, \&c,

100 Scaip of a celebrated Indian chief curiously ornamented; and part of a bomb-shell, which destroyed several people during the siege of 'cibraltar

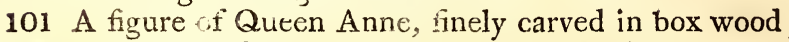

10.2 Box made of the royal oak, inlaid with silver

103 Angler-Lophius piscatorius

104 Bilance fish-Squalus Zygcena

105 Lophius Piscatorius, the fishing frog or angler

106 Two varieties of Cyclopterus Lumpus, lump sucker

107 Salmo Alpinus, var and another, in two cases

108 Saw-fish-Squalus Pristis

109 Kite-fish

110 Man of War, or large gar-fish, America

111 Dolphin-Coryphana hippuris

112 Cancer Norvegicus, the Norway lobster

113 Porcupine fish-Diodon Hystrix

114 The sucking fish-Echineis Remora

115 The swallow-tailed file fish, in a glazed case

116 Tetrodon Lavigatus, ditto

117 Muræna of the ancients ditto-Murcena Helena

118 Porcupine Globe-fish, and the toad Lophius ditto

119 Short-clawed lobster, a fine specimen

120 A gigantic specimen of the common crab-Cancer Pagurus 


\title{
SECOND DAY.
}

\author{
Tuesday the 6th of May, 1806.
}

121 A branch of the warted gorgonia, Millepora alcicornis, and madrepora radiata

122 A gun which burst in the hands of Lord Gray's game-keeper, without injuring him

123 A brace of Highland pistols

124 A Persian gun, with the stock curiously inlaid

125 A singular Chinese gun, ornamented with silver ferrules

126 An air gun

127 A gun which belonged to the late $\mathrm{E}$. Wortley Montague

128 A brace of pistols, which belonged toditto

129 A rifle-barrelled gun, North America

130 A gun, supposed to be antient English

131 A long gun and rest for ditto, by which General Wedderburne, brother to the late Lord Roslyn, was killed, while reconnoitring a fort in the East Indies. The shot he received could not be accounted for till the fort was taken and this gun discovered, the distance being so great

132 Four beautiful specimens of the iridescent scum of melted lead, in a glass-case

133 Six ornamented arrows, Bengal; and a bow from Africa

134 A quiver of barbed arrows

135 A bird arrow, and a bow

136 An elegant modern French bow

137 Chimara monstrosa, and another fish, in one bottle

138 Anguis Platura, a fine specimen, in spirit

139 Black hæmatites iron ore, formed in stalactites

140 Magnetical iron ore, or loadstone, Norway 
141 Two specimens of fortification-like agate, an oriental jasper, and a pudding stone, Hertfordshire

142 Garnets imbedded in mica, Cyanite Tyrol, green copper with quartz and topazine crystals

143 Three specimens of jaspar, ribband-jaspar and agate

144 Pitch-stone, Siberia, green actynolite black shorl, and oriental calcedony of an orange colour

145 A large specimen of amethystine quartz

146 Jaspar of a grass-green colour, very rare, Siberia

147 Brown quartz lining the fragment of a nodule, and a large mass of crystallized quartz

148 Black hæmatites iron ore, having the surface finely coloured, Triers

149 Shorlite from Altenburg, Saxony; and amethystine quartz, Palatinate

150 A mass of crystallized topazes, Siberia

151 A curious hollow agate pebble internally coated with amethystine quartz, cut and mounted as a snuff-box, and another box of Friars's gray marble, Italy

152 A beautiful speckled agate of a dark reddish colour; a large specimen, Oberstein

153 A fine orange coloured cornelian, ditto pink, and an onachine ditto

154 Crystallized molybdate of lead, Carinthia ; and gray cobalt, Germany

155 An elegant specimen of green and blue crystallized malachites, Bannatt; and a vein of fortification cobalt embedded in the matrix, Hesse

$156 \Lambda$ beautiful mass of crystallized white zeolite, Ferrol

157 Onachine, green and blue labrador, Feldspar; and another richly variegated with resplendent purple, azure and gold, two very handsome specimens

$158 \mathrm{~A}$ beautiful specimen of calcareous deposition richly tinged with brilliant purple, from the cobalt mines of Hesse-rare

159 A singular sponge, and a variety of Madrepora Virginea, or stellated coral Bahama Islands

160 A curiously formed, or conic variety of madrepora fungites

161 A fine specimen of millepora alcicornis, having a large serpula, and other shells imbedded in its surface

162 A large and curious sponge

163 Madrepora Crater of Ellis, or cup coral, a noble specimen, East Indies

164 A variety of spongia officinalis

165 Gorgonia pretiosa, an elegant and interesting group

166 Madrepora foliosa of Pallas, foliated coral, East Indies

167 The lower valve of a large oyster, having several delicate shoots of Gorgoia pretiosa, in their first stage of growth, naturally affixed to the inner surface 
168 Madrepora muricata, Linn, prickly white coral, West Indies

169 Millepora truncata, and a curious sponge

170 Four interesting species of exótic sponges

171 The Gondola Argonauta, rare; the broad ear, scarce; and a small Nautilus Pompilius, Linn-all from China

172 The spider Strombus of an uncommon size, South Sea

173 The Holland Flag Chersina, from Cuba, a reverse Chersina, China; and the granulated Cochlus from New Zealandall rare

274 The great cockscomb oyster, Friendly Isles

175 A large and fine Argonauta Argo, Linn; or wrinkled papersailor, Mediterranean

176 The tiger Trochulus, New Zealand-very rare

177 A fine Spondylus armatus, or armed hinged oyster

178 Conus tesselatus, Madagascar, the Devil Murex, and a leopard cone

179 Chinese roof sun, Isle of all Saints, extremely scarce; the tulip cone, Madagascar; and the girdle cone.

180 A very large Triton's trumpet, with adhesions of oysters, Sicily

181 Whin Chatter, Reed sparrows; small water hen, and a variety of the bullfinch -4 cases

182 Water-rail, wood-lark, yellowhammer, and storm-finch4 cases

183 Splendid parrot, Psittacus splendidus, mas. New Holland

184 Psittacus hæmatodus, ditto

185 Two specimens of fighting cocks, trimmed and armed for fighting

186 Psittacus Alexandri, the Alexandrine parrot

187 Gray parrot, Psittacus erithacus

188 Two fine specimens of the bittern, in one case Ardea stellaris

189 A specimen of the Whidaw bird

190 Bramble finch, and sandpiper-2 cases

191 A mottled variety of the blackbird; and white and brown ditto of the swallow - in 2 cases

192 Solitary thrush, Gibraltar : and Cross-bill-2 cases

193 Two wrens, hedge-sparrow, jacksnipe, and greater butherbird, Lanius Excubitor-4 cases

194 Thrush, Gibraltar; sandpiper, quail, and brown linnet-4 cases

195 Black-headed-finch, South America; 2 wrens, and white variety of the linnet-3 cases

196 Upupa Promerops, C. of G. Hope-rare

197 Very fine specimen of the osprey, Falco haliatus

$198 \mathrm{~A}$ cock and 2 hens of the pencilled variety of the common fowl, Denmark

199 Ampelis Pompadora, Pompadour chatterer

200 Bohemian chatterer, Ampelis garrulus, in a mahogany case 
201 Shoveler duck, Anas clypeata; and pigeon-2 cases

202 Night heron, Ardea nycticorax

203 Sea-lark, variety of Canary-bird, and a variety of the skylark -3 cases

204 Flaxen mantle, Nootka Sound

205 War-club, New Caledonia; Patapattoo, New Zealand

208 Feathered helmet, and short feathered coat, Sandwich Islands

209 Model of a canoe, Cook's river; and drum, Sandwich Islands

210 Hand-weapon of stone, and a hemp-beater from Nootka Sound

211 A very fine and large scarlet feathered cloak, Sandwich Islands

212 Head ornament formed of feathers, from ditto; and bracelet of boar's tusks Otaheita

213 Idol, curiously constructed of feathers, \&c. Sandwich Islands

214 Singular w ar-weapon, Nootka Sound

215 Very large spear, ornamented with seals teeth, \&c. from Nootka Sound

216 Two casts of coralloids, Maestricht; chain coralloid; and another

217 Two beautiful impressions, or casts of coralloids, Maestricht ; and a third from ditto

218 Impression of a fish in black slate, Isleben; skeleton of a fish, Papenheim ; large fossil tooth of a shark, Malta; and the head of a fish, Sheppy Island

219 The lily encrinus, Brunswick

220 A mass of limestone, with several teeth of a large species of lacerta, Bath

221 Fossil elephant's tooth .

222 A large and fine orthoceratites imbedded in marble, Oeland, Baltic

223 Egyptian pebble, cornelian, having the cavity lined with quartz; and 2 agates

224 A large black crystal, Bohemia, and rose quartz, Siberia

215 Blood stone, East Indies ; another clouded with brown, an Egyptian pebble, and 3 agates, Scotland

226 A beautiful small polished slab, in which, agate, quartz crystal, jaspar, and amethyst, are united, Saxony ; Egyptian pebble, and 2 Oberstein agates

227 Pitch-like coal, in which the texture of fir wood is perfectly preserved, rare, from Hesse

223 Bituminous wood and coal, having a number of small well preserved seeds imbedded in it, a rare specimen, Germany

229 Two mochas, Scotch agate, cornelian, chalcedony, and 2 ditto hydrophanous and a knife handle of brown crystal 
230 A considerable portion of a very large crystal of tungstein, Saxony

231 Silver ore in jaspar, and a fine specimen of brown pearl spar, Hungary

232 Sinople, a variegated red and white jaspar, very rare, Siberia

233 Violet cubic fluor, with slightly bevelled edges; grayish ditto, with ditto, Derbyshire; violet cubic fluor, sprinkled with delicate quartz crystals; and an elegant crystal of amethystine fluor, partially coated with pearl spar, Durham

234 Native gold on a cark mine stone, Hungary

235 Finely crystallized brilliant gray cobalt, Hesse-a large specimen

236 Two elegant specimens of apple-green and purple zeolite, Palatinate

237 Two specimens of cinnabar, with native mercury, and crystallized horn quicksilver

238 An uncommonly beautiful mocha, white ditto, with red dendrites, fine white cornelian, and red ditto

239 A specimen of stalactitical and mammillated iridescent iron, of uncommon magnitude and beauty, Triers

240 An extraordinary fine specimen of phosphorescent resincoloured blend Kapnic; the crystals very large and well defined

End of the Second Day's Sale. 


\title{
THIRD DAY.
}

\author{
Wednesday the 7th of May, 1806.
}

241 UCERTA Monitor, the monitory lizard, var. and anotier lizard

242 A small crocodile

243 Blennius fasciatus, and Esox belone, the common gar-fish

244 Amphisbæna alba, in the highest state of preservation

245 Squilla adactyla, (Cancer mantis Linn)

246 Amphisbæra fuliginosa, and the blue snake of America

247 Monoculus Polyphemus, and muræna conger

248 Lacerta muricata, two other lizards, and a fish, in all three bottles

249 A rurious lizard

250 Scull of the porpoise

251 Least weasel $\mathrm{m}$. ard fem.

252 Hare, Java, cavea agoreti; and a young specimen of ditto

253 Fox, Hudson's Bay

254 Commun rabbit, and a small lap-dog

255 Black squiriel, N. America, Sciurus niger

256 Long-eared bat, hedgehog, fem. water shrew, and shrew, variety

257 Water-rat, N. America

258 Porcupine, N. America, Hystrix cristata

259 Flying squirrel, sciurus volans, Russia; and common squirrel

260 Tyger cat, felis pardalis, Africa; one out of case, vcry rare

261 Kanguroo, young

262 Kanguroo rat, out of case, Macropus minor

263 Skunk, N. America 
264 Fox, N. America

265 Rat, N, America; and white variety of common rat

266 Summer duck, mále, Anas sponsa

267 Bone of the Gorgon flabellem, or Fan Gorgon, West Indies

268 A large and very handsome specimen of ditto, on a stand

269 A small gorgonia, naturally affixed to a madrepore

270 A curious lobated sponge

271 Millepora alcicornis, Ellis; elk’s horn, coral, West Indies; and another

272 Madrepora fungites, of singular growth

273 Millepora alcicornis, Linn. elk's horn, coral

274 The silver pheasant, beautifully cut in paper, framed and glazed

275 The Prodigal Son's supper, curiously represented in wood

276 An old ship bolt, having a large oyster attached to one side, and a piece of an old anchor, with gorgonia verrucosa and serpula attached

2ヶ7 An ornamented copy of the ten commandments, written by Matthew Buchinger, who was born without hands or feet

278 A curious brown perforated sponge

279 Warted gorgonia, on a pinna shell

280 Conus Monachus, Madagascar ; the painted tun, New South Wales; and a conus pulicarius, having the epidermis-all fine

281 The Ham Pinna, of a large size, Mediterranean

282 The great black Pinna, South Sers

283 A muricated trumpet, with a richly-coloured mouth, Tranquebar; and a large banded variety of the aculeated cassidula, West Indies

284 A large bronzed trochus, from Nootka Sound; the monk cone, and the groom cone

285 A large iris ear, New Zealand, uncoated

286 Two of conus mutabilis, Solund. from Guinea; the violetmouth scoop, South Sea; the brown windlass; a handed reverse Chersina; and a clouded helmet-all rare

287 A large and fine spondylus armatus, or armed hinged oyster, Madagascar

288 The South Sea snake, uncoated, the leopard cone of Java, and a large brocade cone

289 A large uncoated zebra trochus, China; and a pugilists fistalatus, Providence

290 The black tiger cone, the panther cone, the brown lineated coquette scoop, and the fine mouth scoop

291 A young devil's claw with the epidermis, a spider strombus ditto, Madagascar ; and an iris ear, New Zealand

292 Conus luridus, Soland. voluta flammea, ditto-both rare; and the fly-spot cone

293 One valye of Ostreaedulis, having a large pearl formed on 
it; a scarce variety of the common oyster, and a purple spondylus

294 The marbled snake, China; and the great triplex, with $a$ crimson mouth, Madagascar

295 Haustrum dentex, from the Gallapagos Isles, very rave; and 2 beautiful cones

296 The iridiscent oyster, Anamaboo, Coast of Guinea ; ostrea corusca, Soland-rare

297 A scarce mya, polished; the ducal mantle, Pecten; ostrea radula, Linn; the cinnabar scallop, ostrea cinnabarina, Born; and a small nautilus pornpilius

298 Strombus truncatus, or great flat spired stromb, China

299 Lanner falcon, male and female, Falco lanerius

300 Heron, young female, Ardea major

301 Speckled diver, Colymlus stellatus

302 Cole Titonrice, male and fem. and cuckows-two cases

303 I' $\mathrm{w}$ wo magies, and two variegated pigeons-two cases

304 Buff-breasted Goosander, Mergus Serralor

305 Red-headed merganser, $\mathrm{m}_{\mathrm{a}}$ and fem. Mergus minutus

306 Water-hen, $m$. and fem. and bantam fowl

307 Quan, Penelope Cristata, W. Indies

303 Golden-eye duck, Anas clangula, m. and fem. and two bart owls-two cases

309 Pettichaps, m. and fem. Motacilla Hippoluis

310 Scarlet and brown woodpecker, S. America

311 White variety of the crow

312 Whistling duck, Jamaica

313 Black starlings, Hudson"s Bay-three specimens

314 Two specimens of the whimbrel, or lesser curlew, Scolopac phaopus

315 Soland goose-Pelecanus Bassamus

\$16 Dottrel, starling, anc' sparrow variety

317 Jackdaw variety, and sparrow variety

318 Razor bill, Alca torda

319 Paris of rare birds of Paradise

320 Six specimens of copper, including beautiful blue crystallized malachite, needle--like ditto, on quartz, \&c*

321 White muriate of antimony on galena, Bohemia-a fine specimen

322 Brown rock salt, two specimens, mock avanturine, guartz crystal, with green internal appearnces, and quartz in the fragment of a module of onachine agate, Palatinate

223 Arseniate of cobalt, Hesse ; brown mica, nickel in quartz, Siberia

324 Tetrnhedral copper on crystals of quartz, Cornwall; cubic fuor, with pyrites and blend, and marcasite

325 Large and well-defined crystals of blue malachite, on a quartzose matrix, fiue and rare, Siberia 
326 A magnificent specimen of crystallized resin-coloured blend, interspersed with delicate white quartz crystals, and calcareous spar, Hungary

327 Native and vitreous copper, in a quartzose matrix, Siberia, yellow copper, with lead ore, Sweden; green stellated copper, intermixed with gray copper, rich in silver, with iron, from Langen Hecke, Triers

328 Crystallized lepidolite, Moravia-extremely fine and rare

329 A rich specimen of golden green labrador

330 Agates, six specimens-two fine

331 A large ard very clear rock-crystal, Switzerland; and four others

332 Two large Oberstein agates, one very beautiful

333 Four English pebbles, one Egyptian, two agates, and an eagle stoue, or Ætites

334 Lapis lazuli, from the Buckarian Calmucks, amethystine quartz, and four other polished specimens

335 Transparent tabular barytes, and a lichen geographicus, on a rock-stone, from Westmorland

336 A fine oriental heliotropiun, or green blood stone, an Egyptian pebble, and quartz crystal, penetrated with needlelike shorl

337 Two polished specimens of Brazilian quartz crystal

338 Dendritical manganese, Menil, France; and manganese of the like figure on quartz, from Hesse-both very rare

339 An elegantly-shaped snuff-box, formed of white rock-crystal

340 A magnificent specimen of topazine columnar, or ròckcrystals, intermixed with very large crystals of aqua-marine, the beryl of the ancients, very rare, Siberia

341 Red zeolite, Sweden; and black shorl, Arragon

342 Fine agates, five from Germany, and two Oriental

343 Native silver pervading galena, and grey silver ore, on rose coloured manganese, Trasylvania

344 Dendritical silver, with quartz, argentiferous lead, and a small specimen of muriate of silver

345 Crystallized manganese, Ilefeld; arsenic; and part of a large crystal of brilliant cobalt, from Hesse

346 Silver ore; on a phesphorescent matrix, Siberia; native silver on jaspar; and native amalgam of silver

347 Native cinnabar, Idria; cinnabar, and quicksilver, Deuxpont; enisform manganese, and pigeon-neck bismuth, Saxony

\$48 Crystallized antimony, Tuscany, and two others

349 Smoky dogs'-tooth spar

350 Selenite, Saxony; and black blend, Cumberland

351 Molybdate of lead, very finely crystallized, Carinthia

352 Transparent vitreous ruby silver, an elegant group of well. 
defined crystals, in the hollow of a crystallized quartz, Saxony

353 Black hæmatites, iron ore, Triers

354 Stalactitical iron ore, having the surface finely coloured with green, Iriers

355 Spicular ruby copper, and a malachite

356 A solid piece of green malachite, Siberia

357 A mass of ruby copper, intermixed with green malachite and native copper, from Siberia, cut and polished; and a specimen of fibrous green malachites, ditto

358 Tabular barytes, with crystals of calcareous spar

359 A noble specimen of the green stalactitic malachite, Siberia 360 Foliaceous knitted native gold, Transylvania-uncommonly fine 


\title{
FOURTH DAY.
}

\author{
Thursday the Sth of May, 1806.
}

361 STANNEL Hawk, and Lace Pigeon, two cases

362 Large speckled Loon, N. America

363 Herring Gulls, North Pole

364 Fishing Eagle, Gibralter

365 Red-winged Thrush, male and female; Goldfinch, male and female; and Nightingale-three cases

366 Small speckled Woodpecker, male and female, N. America ; Yellow-breasted Fly-catcher; Black Cap, Gibralter-three cases

367 White-throat, Gibraltar; Sparrow variety; and Wheat-ear, Cape of Good Hope

369 Anas Cygnus ferus, Wild Swan

369 Pelican

370 Spotted dusky Duck, Hudson's Bay

371 Red-headed Woodpecker, Canary Bird, Hawfinch, and Dottrell - four cases

372 Night Heron-Ardea Nycticorax

373 Fly-catcher, Janaica; small-spotted Woodpecker, and lesser Tern, male and female- 3 cases

374 Rumpless Fowl, cock, hen, and young

375 Barnacle Goose, and lesser horned ow!

376 Man of War bird, Pelecanus Aquilus, N. America-rare

377 Red Flamingo, young, Phoenicopterus ruber, Jamaica

378 Blood-stone, a large and fine cornelian, onachine pebble, two beautiful agates, and another 
379 A slab of iridescent labrador, Feld-spar, of uncommon splendor, in which purple, orange, blue, and gold are most happily combined.

380 A very capital specimen of black shorl, adhering to its rocky matrix, Germany

381 Large and fine specimen of brilliant gray cobalt in the matrix, exhibiting the natural dimension of the stratum, Hesse

382 Two rare varieties of red crystallised oxid of copper, Si. beria; and yellow copper, with fluor and ditto, Sweden

383 A large mass of iridescent labrador Feldspar, variegated with orange, green and blue of various gradations

384 A fine specimen of cone in cone coralloid, Derbyshire

$385 \mathrm{~A}$ cluster of fossil fungus-like coral, and a fossil madrepore

386 Two impressions of small fish, in laminated indurated marl, Papenheim; and three fossil teeth

387 Head of the lily encrinus, Brunswick; encrinus, Charmouth ; and another, and madrepore in chert

338 Parts of two heads of fossil encrini, and various fragments of encrini, and star-fish

389 An impression of a fish in laminated indurated marl, and the legs of a crab in ditto, both from Papenheim; and various parts of fish palates, chiefly from Gloucestershire

390 A belemnite in friable calcareous stone Maestricht. This specimen is in good preservation, and has the apex nearly perfect

391 Two fragments of an orthoceratites, Oeland

392 A fine impression of a large fish in black slate, Isleben

393 A mass of fossil coral, and another mass, with impressions of ammonitæ, \&c.

394 Part of a large Orthoceratites, and a cluster of fossil coral

395 Specimen of Persian cow's tail, out of case

396 Cone in cone coralloid ; and part of a large Orthoceratites

397 Cerambyx imperialis, Africa; four of C. maculatus, West Indies, fasciatus ditto, and five more

398 Curculio imperialis or diamond beetle, Brazil

399 Lethrus AEneus, buprestis variabilis, and melolontha viridis Don. New Holland, with two cerambyces

400 Twenty" nine coleopterous insects, chiefly of the ceram. byx, and leptura genera, several from New Holland

401 Citrculio spectalitis, or New Holland diamond beetle; Lethrus Funeus, Buprestis punctatus, and two more

402 Two large and curious species of the Prionus genus

403 A large and rare species of Cerambyx, South America

404 Cerambyx longimanus, scarce

405 Seven specimens, chiefly of Cerambyces, Curculio palmarum, \&c.

406 Five specimens of Cerambyces 
407 Curious feathered idol, Sandwich Islands; and a dagger, from ditto

408 Provision case made of a remarkably large gourd, from do.

409 Drum from ditto, and a model of a canoe

410 White feathered cloak, with a dark fringe of feathers, from ditto

411 Curious idol, formed of a dark, heavy wood, from Easter Island

412 Idol, formed of the wood of the bread fruit tree

413 Beautifully carved war club, Friendly Island

$414 \Lambda \mathrm{n}$ arrow case, carved and ornamented with seals' teeth, from Nootka Sound

415 Buzzard Hawk, N. America

416 Curasso bird, male-Crax Alector

417. Scarlet Ibis-Tantalus ruber

418 Mocking Thrush-Turdus Orpheus, N. America

419 Variety of the Rook, and ditto of the common Duck

420 Curious lobated sponge

421 Bottle brush-sertularia, cats'-tail sponge, and another

422 Singular cavernous sponge

423 Butter print, coral

424 Cavernous wiry sponge, West Indies

425 Warted gorgonia, (verrucosa) Mediterranean

426 Gorgonia aculeata, or prickly gorgon, with adhesions of oysters, from the West Indies

427 Long-branched warted gorgon adhering to a shell, and another arfixed to part of an iron hoop, Mediterranean

428 Gorgonia flabellun, and a warted gorgonia, Mediterranean

429 The black tyger cone, (Conus marmoreus Linn.) the plough alatus, and an undulated helmet

430 A group of nine odd valves of the purple oyster, S. Sea; and a large spider Strombus

431 A large conus literatus, Madagascar; a butter firkin cone; and a plaited helmet

432 A fine Spondylus armatus, Martinique

433 A large muricated trumpet Madagascar, and a young Conch

434. The zigzag pecten, (Ostrea ziczac Linn) Providence; and a beautiful haliotis iris, New Zealand

435 A fine purple spondylus, Mediterranean

436 The bull's mouth helmet (Buccinum rufurn Linn) of extra: ordinary magnitude, and two wrinkled ear shells

437 A large spider, China; a young Alatus Gigas, and a Cuma Tulipa

438 The short-rayed Sun, from Nootka Sound; the embossed frog, Guinea; the pagoda turbo, Amboyna; a heimet. with an oyster adhering, and a large shagreened trochus, from China

439 A large Rhombus Lacerta, or lizard Romb, China 
440 A small conus grandis, a butter firkin cone, a striated, a deformed zebra alatus, and two others

441 Spondylus armatus of extraordinary size, the under valye being near 7 inches in length, Martique

442 Strombus truncalus, or great flat-spired Stromb, China

443 The Mountain Road, Rhombus, Tranquebar, scurce; the lineated Buccinum, New South Wales; and the ragged Buccinum, Madagascar

444 Conus tæniatus Solund. from Madagascar ; the Tiger Ler:dix from Brasil; and Conus luridus Soland-all very rare

445 The black hammer, Margaritifera, (Ostrea malleus Linn) Pulo Condore, rare

446 A scarce reticulated Buccinum, W. Indies; the crown of thorns, Cassidula; a ribband Lunatus, the mulberry, and and knobbed Trochus, and a muricated trumpet

447 A purple Spondylus, Sicily; and a group of several shells of the Gryphusbicolor kind, W. Indies

448 A very large aculeated Cassidula (Murex Melongena,) W. Indies

449 A young of the great W. India helmet, (Buccinum grande) and a large flag cone

450 The great cockcomb oyster, Friendly Isles

451 A scarce trochus, a pagoda Turbo, the violet-mouth Porcupine, the gold-mouth Senectus of the Friendly Islands, a clouded tun, and a stair case

452 Three agates, one very fine, all from Oberstein

453 The great American Pecten, (Ostrea grandis) rare, the opal mussel, China; and a wrinkled ear, (Haliotiş Midæ) Cape of Good Hope

454 The high Admiral, (Conus Ammiralis) Linn Amboynạ, rare

455 The luxuriant Bulb (Bucc. luxurians) China; voluta ancillą, Falkland Isles, rare; and a large white English Rhombus

456 A fine specimen of calcareous deposition, tinged of a delicate pink colour, from the cobalt mines of Hesse, very rare

457 Gray cubic fluor, Derbyshire

458 Three mochas, two white cornelian rings, amethystine quartz, with a Greek inscription engraved on it

459 A fine piece of brown rock chrystal cut and polished, and two agates, Scotland

460 Lapis lazuli, from ancient ruins in Italy, originally frop̧ Gambaroon, Persia; Egyptian pebble, agate, Germany; and mock avanturine

461 Five polished pebbles, one ditto, Oberstein; chalcedony, ditto, and jaspachates, Oberstein

162 A singularly curious agate, representing a pair of spectacles of a red colour on a white ground an Egytian peblale, and Brasiianan quartz 
463 A large hollow nodule of agate internally coated with ame. thystine quartz, and containing a crystal of calcareous spar

464 Molybdate of lead, Carinthia ; and bubbled calcedony, Cornwall

465 A polished specimen of the great Leverian calcedony, East Indies; a brown double-pointed crystal, Falkland Island; an oriental agate, and another from Siberia, of a delicate violet colour

466 Two specimens of stalactitical iron; Triers; and black hæmatites, Saxony

467 A fine specimen of fibrous green carbonate of copper, Siberia 468 Native copper, Turkey; fibrous green carbonate, Peacock copper, and another

469 A magnificent specimen of blue crystallised copper, Bannatt

470 Molybdate of lead, Carinthia

471 Malachite copper, cut and polished, a fine specimen Siberia

472 Native ramose silver, Norway

473 Compact Tellurium, (Aurum graphicum)

$474 \mathrm{~A}$ bottle of platina

475 Foliated native gold, Transilvania

476 A noble mass of native copper, from the neighbourhood of Lake Superior in America

477 Flexible stone; a large piece, Brasil

$478 \AA$ fine specimen of pure Plumbago, or Graphite, Cumberland

479 A rich specimen of ruby copper, finely crystallised, the mass intermixed with malachite, crystallised, and native copper, Siberia

480 Hair-crystal, or Titanium, in reedle-like crystals, enclosed in pelucid quartz, a superb fine specimen, from Mada gascar 


\section{FIFTH DAY.}

\section{Friday the 9th of May, 1806.}

481 ATAPATTOO, New Zealand; war-club, New Caledonia; and ditto, Friendly Islands

482 Feathered cloak, Sandwich Islands ; and a dagger, from do. 483 Fish gig, with a singular instrument for throwing it, Onalaska; and a carved arrow-case, from Nootka Sound

484 A very curious barbed spear, twelve feet in length

485 Drum, Sandwich Island; basket, New Caledonia

486 Dark green and yellow cloak, Sandwich Islands; and dagger, from ditto

487 A feathered helmet, ditto; and a fly-flap, ditto

488 Head of a dancing shield, formed of feathers; and a small feathered cloak, from ditto

489 Mask, in memory of a dead friend; and a dancing rattle, shaped like a bird, King George's Sound

490 Another mask, from ditto, and model of a canoe

491 Curious ladle, Sandwich Island; and a gourd provision case, ditto

492 Ornamented gourd bottle, from ditto

493 Patapattoo, New Zealand; war club, New Caledonia; and ditto, Friendly Islands

494 Feathered idol, Sandwich Island

495 A very handsome model of a bark boat, from Canada

496 Singular war weapon, Nootka Sound

497 Curious cup, with two supporting figures, Sandwich Islands //

498 Curious offensive weapon, set with Sharks' teeth, Sandwich Island

499 Jaspachates, or agate combined with jaspar, Oberstein ; an Egyptian pebble, large fortification agate, and another 
500 A large piece of oriental jaspar, and amethystine quartz, coated with calcedony, Oberstein

501 Gray silver ore, Sax́ny; and steel-grained lead ore, rich in silver

502 Selenite, Saxony; and polyhedral black blend, with pearl spar

503 Manganese in a globose form, with a smooth surface, in the cavities of an iron ore, from Triers, in Germany

504 Red hæmatites iron ore, on black hæmatites iron ore, having a glossy surface, and yellow ochre at the base, from a mine near Catharinenburg, in Siberia

505 Molybdate of lead, Carinthia; and an iron, from Triers ?

-506 A curious green zeolite, Norway 2 .

-507 Iridescent needle antimony, on tabular barytes, Felsobania, Hungary

508 A fine slab of ruby copper, intermixed with malachite and native copper, Siberia $/ 6: 6$

509 Stalactitical iron, Triers

510 Two specimens Molybdate of lead, Carinthia; and a white carbonate, Scotland

511 A very fine group of crystallised ruby silver, Hartz $/ 212$

512 A large and rieh specimen of iridescent mammilated iron, from Triers

513 A piece of Brasilian rock crystal, cut and polished, exhibiting most beautiful iridescent colours; and another crystal in its native state

514. Part of a very large and beautiful nodule of agate, inclosing quartz, Oberstein

515 Hard green oriental Egyptian porphyry, a slab of antique blue glass, made in imitation of lapis lazuli, from ruins in Italy; and four other polished specimens

516 A very fine and large yellow cornelian

$\$ 17$ Wood-like jaspar, Siberia; red agate in quartz, and artificial avanturine

518 Jaspachates, two agates, from the Palatinate; Egyptian peb. ble, and two more

319 Crystal of quartz, with hair-like internal appearances, and four other crystals

320 Stellated green sattin-like malachite, with crystallised blue malachite on vitreous copper, Bannatt; and green efflorescencc, with copper and iron ore intermixed, Thuringia

521 Black octohædral tin ore, in a group of rock crystals, sprinkled with green mica, and combined with brownplated barytes, cubic flour, \&c. \&c. a highly interesting group

522 A slab of map-like prismatic labrador of exquisite beauty, combining the orange, blue, and gold, in elegant variega. tions

$523 \Lambda$ large group of cubic fluor, sprinkled with marcasites 
s24 White-headed Tern, $m$, and fem. Water Hen, N. America; two cases

625 Starling variety, and Fieldfare, two cases

526 Mungrel Canary, Red-pole, ditto variety, and Reed-sparrow four cases

527 Large blue dove, W. Indies; and Powter Pigeon, two cases

$5 \approx 8$ White-fronted Parrot; Wood Owl, hen; and Woodcock variety, three cases

529 Tringa Pugnax, green Plover, $m$. and $f e m$. and Parroquet, S. Seas, three cases

530 Collared Starling, Gibraltar; larger Butcher bird, Goldfinch; and Sparrow variety, four cases

531 Blue and green crystallised malachite copper, Bannatt; blue copper, Thuringia ; and a yellow sulphuret in quartz

532 Sixteen small specimens of marcasites, some well crystallised

533 Pelican, New Holland

534 Song Thrush, m. and fem. Missel Thrush, and Wrens, three cases

535 Oyster-catcher, Hematopus Ostralegus; and Wood Pigeon, two cases

536 Soland. Goose, Pelicanus Bassanits

537 Psittacusa rarauna, (out of case) and Goosander

538 Red-shouldered Starling, orioltus phæniceus, N. America, $m$. and fem. brown headed Grossbeak, $m$. and fem. America-two cases

539 Sparrow of Paradise, white Wrens; $m$. and fem. and Linnet variety, three cases

540 Crested Pheasant, Phesianus Hocco, S. America, very rare

541 Bohemian Pheasant

542 Todus lucocephalus, white-headed Tody, America

543 White-headed Manakin, Pipra leucocephala, Surinam

544 Nuthatch; Sitta Europaea; grey Wagtail, Motacilla boarola; Bohemian Chatterer, Ampelis garrulus, female; and Bullfinch variety, 4 cases

545 Sea Eagle

546 Buprestis vittata, and imperialis; Blatta heteroclita, larva of a Blatta, \&c. in all thirteen specimens

547 Scarabøus Molossus, Lucanus Cervus, Mylabris cichorei, var. \&c. altogether twenty

548 Buprestis sternicornis, and imperialis, Scarabæus Molossus, Cimex aurantius, \&c. fourteen specimens

549 Buprestis fascicularis, Brazil, rare; Scarabæus sacer, Silpha brumea, and seventeen others

550 Buprestis imperialis, and two others, a tabanus, a curious Staplıylinus, and fifteen others

551 Scarabæus Molossus, Buprestis vittata, and seven otherg

552 Six Sphinges, chiefly from N. America 
553 Buprestis sternicornis, two specimens, India; four Indian cimices, Mylabris Cichorei, \&c. thirteen specimens

554 Curculio palmarum, Cimex pictus, Carabus bimaculatus, Cetonia viridis, and thirteen others

555 Specimen of Persian Cow's-tail, in glass case

356 Sphinx Celeris, Ocellata, fuciformis, Papilio Levana, and fifteen others

557 Curious netted sponge, supposed variety of Spongia Cancellata

558 A large and fine coloured purple variety of Gorgonia flabellum, and another divested of the flesh

559 Gorgonia flabellum, a cavernous sponge, and muricated Millepore

560 Millepora foliacea, a fine specimen

L $561_{1}$ Curious muricated sponge on its native rock, to which also adheres an orange-coloured spondylus sheil, West Indies

562 Madrepora Seriata of Pallas, from the East Indies, a delicate specimen

563 Gorgonia Setosa, Linn. Bahama; Millepora alcicornis, and muricata

564 Long-branched warted gorgon, Mediterranean; singular sponge, and another

565 Stem of a gorgonia, with a large serpula shell adhering, and both overrun with a millepora alcicornis, from the West Indies; Spongia infundibuliformis and gorgonia flabellum

566 Stony-white Millepore, Mediterranean; Millepora Polymorpha, Linn.

567 A bottle which having lain some time in the Sea, is overrun with serpulæ

568 Curious sponge adhering to a Pecten Ostrea, and one shell of a bivalve exhibiting delicate shonts of isis nobilis, affixed by its natural base to the inner surface

569 Madrepora Agaricites, Linn. West Indies

570 The lesser tulip cuma, Florida ; and a Buccinum, Falkland's Isle-both rare

571 A capital group of five purple spondyli, with other adhesions, Sicily

372 A fine orange-mouth ear-like terrestrial shell (Voluta elongata Soland.) New Caledonia-very scarce

573 The butter-firkin cone (Conus letulinus Linn) from China; and a scarce pink variety of the zebra Trochus

574 A fine heavy turnip, (voluta gravis Soland.) Straits of Malacca; and a pair of beautiful small triton's trumpet, Sicily

575 A large and fine Midas's-ear land shell, (Voluta aur. Mid. Linn) Malacca-very rare

576 The ham pinna, of extraordinary size, Mediterranean

577 The shower clam, (Venus nimbosa Soland). Florida, rare: the great English pecten, and two others 
578 The painted cone, Cape of Good Hope; the brown porcupine, and a flambeaux cone

579 An iris ear, New Zealand; and a compass pecten, China

580 The cornuted helmet, in a young state; and a dissected undulated helmet

581 The variegated spondylus, South Sea ; a group of odd valves of the long oyster, and two others

582 Conus imperialis, from Amboyna ; the flag cone, Madagascar; and the waved emerald sea snail, from Van Dieman's Land

583 A section of the Nautilus Pompilius, and an Iris ear

584 The tiger cone, rare; a striated cone, and a knobbed sunshell

585 Licium textorium, the weaver's shuttle, (Bulla volva Linn) Japan-extremely scarce

586 Precia-like jasper, Sicily ; transparent agate, exhibiting singular reticulated moss-like internal appearances; another, somewhat similar, and an Oberstein agate

587 A fine ocellated cornelian, East Indies; an Egyptian pebble, Scotch agate, and agate, Germany

588 Green oxyde of copper, in quartz, Germany; green and blue malachites, Bannatt; yellow copper, Sweden; and another

589 An elegant circular box, formed of pudding-stone

590 Very large and fine specimen of Tellurium, Transylvania

591 A superb specimen of Elos ferri, Styria

592 Pudding-stone, Hertfordshire; quartz crystallized, Cornwall : and another

593 Three specimens, honey-stone, chrysoprase; and a single primitive crystal of quartz

594 Silver ore; and native silver, in agate, cut and polished

595 A box, made of exquisitely-beautiful matrix of opal, not mounted

596 An hexagoual crystal of quartz, filled with actinolite

597 An interesting specimen of Brazillian crystal, replete with needle-like crystals of titanium $\%$

598 Two specimens of Prehnite, one having the surface crystallized

599 Basso-relievo carving of His present Majesty, when young, executed in canal coal, by a weaver

600 $\mathrm{A}$ fine and large specimen of quartz, most cuilously intersected, internally, with fascicnli of capillary actinolite

Fnd of the Fifth Day's Sale. 


\section{SIXTH DAY。}

\section{Saturday, the 10th of May, 1806.}

601 AtapatToo, New Zealand; war-club, New Cale donia; ditto, Friendly Islands

602 Richly carved war-club, Friendly Islands

603 Mask, resembling a bird's head, and a bird-like rattle; Nootka Sound

604 Singular war-wieapon, ditto

605 Ornarnented gourd bottle, Sandwich Islands

606 Model of a canoe, and ditto of a bird, Nootka Sound

607 Very curiously ornamented tuncated cap, from Nootka Sound; and truncheon, formed of bone, fiom ditto

608 Elegant white feathered cloak, Sandwich Islands; feathered dagger, from ditto

609 A small brown feathered cloak, and a feathered helmet; from ditto

610 Bracelet, made of boars tusks, and a feather ne:klace, ditto

611 A barbed spear, formed of a beautiful mahogany-like wood, ditto

612 A very large ánd handsome drum, from ditto

613 A curious wooden can, Nootka; and a kind of scoop, formed of bone, from ditto

614 A pair of fur boots, from Cook's river

615 Head of a harpoon, and singular fish-hook, Nootka Sound

616 Curious necklace, formed of bone; and an ear-ornament, from ditto

6 i7 Hemp-beater, and comb, from ditto

618 Curiously inlaid Persian gun 
619 A pair of very ancient and beautifully inlaid Persian pistols

620 A curious ancient gun

621 A remarkably curious magazine gun

622 Casts of two echini, in a mass of chert, one of which exhibits on the surface the casts of several of the spines, which in the recent animal appear to have been hollowa curious specimen

623 Part of the jaw of a species of Lacerta, fossil

624 An uncommonly magnificent specimen of the Lily encrinus, from Brunswick

625 , Fragment of the body of an echinus, with several club-like spines attached, imbedded in chalk

626 A very curious fossil palate of a fish, extremely scarce

627 Fragments of ammonitæ, three specimens, two having part of the inner or pearly coat remaining

628 Part of an echinus, having many of the spines complete, im. bedded in chalk

629 A very large fossil tooth of an animal of the shark tribeweight, eleven ounces

630 A gigantic specimen of the Dudley anthropomorphita-very rare of this magnitude

631 A remarkably fine impression of a fish, on black slate, from Isleben

632 The two valves of ostrea poiyleptoginglynos from Weinheim, near Triers

633 Two specimens of a species of helix, very nearly allied to helix-leucorum imbedded in a fragment of the Gibraltar rock. The merit of this specimen consists in the shells retaining much of the variegated colour and markings which characterised the living shell

634 A pecten, Sicily, (Ostrea Linn.) and another

$635 \mathrm{An}$ impression of a fish in Papenheim, laminated indurated marl, having a considerable portion of the skeleton, complete

636 Goldfinch, m. and fem. ; Merops apiaster; Woodcocks, young, two specimens; Pit-wren, four specimens-four cases

637 Rose-throated Flycatcher, m. and fem. Gibraltar; and Black-throated Bulfinch, $m$. and fem. Africa-two cases,

638 Wood-lark, Reed Sparrow, Hedge Sparrow, Sparrow, (white variety,) and House Martin-five cases

639 Yellow-throated Flycatcher, Brazils; small pied Flycatcher, America; Fire Finch, Africa-three cases

640 Golden.headed Titmouse, two specimens; black and white striped Flycatcher, America-two cases

6.11 Corvus Cornix, Royston Crow, m. and fem.

642 Tufted variety of the common duck

436 Mottied turkey, and Phasianus Colchicus, fem.-two cases 
644 Sparrow-hawk, and fan-tail pigeon-two cases

645 Turnstone, Tringa interpres, $\mathrm{m}$ and fem. and large white Tern-two cases

646 Eider duck, m. and fem. Anas mollissima

647 Storks, Holland, m. and fem. Ardea ciconia Linn

648 Bohemian pheasant, and luybrid pheasant-two cases

649 Two beautiful varieties of Phasianus Colchicus, $m$. and $f$.

650 Sandpiper, Blackcap, Goldfinch variety, and Goldfinch, $\mathrm{m}$. and fem.-four cases

651 Titlark variety, Bulfinch variety, Sparrow variety, and Certhea familiaris, m. and fem.-four cases

652 Water Rail, South Seas-very scarce

653 Speckled Woodpecker, N. America

654 Sparrow-hawk, white variety of Starling, Java Sparrow, and another-four cases

655 A curious cast of fossil madrepore, having the surface sprinkled with calcareous crystals

656 Large gray seal, Phoca vitulina

657 Coati-mondi, Viverra nasua

658 Ant-eater, S. America, Myrmecophaga tetradactyla

659 Fox, Hudson's Bay

660 A large specimen of chain coralloid

661 Macauco, Lemur Catta, out of case, and a very small lapdog

662 Beavers, Castor Filcr

663 Five specimens of fossil coral, and a polished slab of marble, with fossils imbeded

664 A mass of fossil wood from Lough Neath, Ireland

665 Sphinx ocellata, ligustri, and two exotic sphinges

666 Sphinx atropos, and four others

667 Phalæna Cercopia, a pair, New York

668 Twelve lepidopterous insects, as Phal. Hebe, Bubo, Caja, Sxc.-

669 Seven insects, various

67.0 Sphinx, Carolina; a pair of large Phalæna, New York; and two more

671 Ten lepidopterous, insects, various

672 Sphinx ligustri, atropos, and three other sphinges, Carolina

673 May-blossom coral, and gorgonia verrucosa, on its native rock, with serpula, and other shells attached

674 Large branch of gorgonia verrucosa, affixed by its natural - root to a stone, upon which a large serpula also adheres

675 Spongia digitata, fingered or glove sponge, from Florida; and gorgonia verrucosa, affixed to an oyster shell

676 Small kind of madrepora digitata, or finger coral, East Indies 677 Yellow gorgonia, natually adhering to a shell, from the coast of Sicily 
678 Madrepora damicornis of Pallas, deer's horn coral, affixed to a fragment of granite incrusted with serpula

679 Sertularia Tamarisca, Linn; cat's-tail sponge, Florida; branched sponge, and another

680 A very large marbled senectus, China, uncoated and polished,

6S1 A spotted melon, Tranquebar; and the pale coloured melon, rare, Guinea

682 A large Nautilus scrobiculatus, Soland. or umblicated sailor shell, New Guinea - very rare

683 The imperial crown, (Conus imperialis Linn.) the partridge helmet, (Bucc. Pomum Linn.) and a spotted tun, all from - China

684 The lineated trumpet, New S. Wales; the woodcock triplex, (murex haustellum Linn) China ; and orange longbeaked Buccinum, Amboyna

685 A pair of the brown-striped yellow Chersinæ, one of them reverse, from Prince's Island-very scurce

686 The angulated turnep, (voluta angulata) Providence-very rare

687 The ramose triplex, two alatæ, different; and a silk brocade cone

688 A bull's-mouth helmet, a plaited helmet, and a tulip cuma

689 The black hound's ear, Vulsella, (Pulo condore) and one valve of a white hammer, Margaritifera, Haynam-loth rare

690 A group of the odd valves of the purple oyster, South Sea; and a devil's claw Strombus

691 A fine Melo Ethiopicus (voluta AEthiopica Linn) or Ethiopian crown melon, Amboynu-rare

692 The lineated triplex, a small Neptune's trumpet, and a triplex ramosus

693 The brown scorpion purpura, (murex scorpio Linn) Amboyna-very scarce

694 A large Nereid's trumpet, $W$. Indies

695 The great flat-spired Strombus, China

696 The Placuna vitrea, or window shell, China; and an under valve of the anamaboo oyster

697 A butter-firkin cone, (Ccnus betulinus,) a plated helmet, and a pyramid trochus

698 Two bronzed trochi, from Nootka Sound, one of them uncoated; and a fine rhombus striatus, Buccinum kana, Soland. from China-both kinds rare

699 A magnificent volute, Norfolk Island, South Sea

700 Stangen-shorl, Germany; and crystallized cobalt, Hesse

707 Two specimens of black iron ore, one crystallized in stalactitites, with a granulated surface

\$02 Native sulphur, combined with magnetic iron ore, Sweden; three specimens of native sulphur, Vesuyius 
703 Nine small specimens, including the Bologna barytes; crystallized broselenite, Hungary ; cauk-cut and polished selenites; black chalk with amianthus, Spain; and four others

704 Green nephritic, or lapis Nephriticus, rare, China; a fine Egyptian pebble, and Brazil-cut crystal

735 Dendritical mica, Spain; crystallized carbonate of barytes, baroselenite, Hungary; cauk of singular figure, silvery mica, and two others

706 Delicately crystallized calcareous spar, from Mexico, very rare

707 Two good varieties of purple fluor, one grayish ditto, with internal variegations of marcasite, Derbyshire; elegant group of violet cubic fluor, partially coated with pearl-spar, Durham

708 A cut specimen of very clear Brasilian crystal, containing several distinct crystals of titanium

709 A most capital mass of the onachine and iridiscent Feldspath, the pervading colours of which are chiefly green, blue, and yellow, one of the finest specimens known, Labrador

710 Stellated zeolite, Iceland-very fine

711 Native ramose copper, from Pokadeschky, near Uralgeburge, Siberia

712 Brilliant minute, but well-defined azure blue crystals of copper ore, in a ferruginous matrix, Germany

713 Sardonyx, engraven with emblematic figures, three beautifully veined agates, and two cornelians

714 Native snow-silver, upon yellow iron ochre, Siberia-very rare

715 A fine specimen of the crystallized white carbonate of Scotland

716 Red stellated antimony, and a piece of crystallized cinnabar

717 A specimen of pharmacolite, in long and delicate radii, from Hesse, (arsenic) very scarce

718 A crystal of smoky quartz, with very remarkable laminated internal appearances, Brazil

719 Thumerstein or violet shorl, very beautifully crystallized, Dauphiny

720 Iridiscent hæmatitic iron, with crystalllzed manganese, and quartz on the surface

End of the Sixth Day's Sale. 


\section{SEVENTH DAY.}

Monday, the 12th of May, 1806.

721 Double cocoa nut, s. Seas

722 Persian target

723 Breast-plate, formed of crocodile's hide

724 Persian bow, and curious instruments of war, formed of tw united Antilopes borns

725 Singular knot of oak, and remarkable root of a tree

726 Chinese fan, and small Chinese gong

727 Psittacus ararauna

728 Goosander, Mergus Nierganser, female; and Recurvirostra Avosetta, Avocet, two cases

y29 Royston Crow, Corvus Cornix; and lemon-crested Cockatoo, Psittacus cristatus, two cases

730 Canada Goose, m. and fem. Anas Canadensis

731 Frizzled fowls, four specimens; and common Curlew, three ditto

732 Wild Swan, Anas cygnus ferus

733 Green Shanks, Widgeon, female; and common Starling, $\mathrm{m}$. and fem. and common Partridge - four case

734 Orange-crested Cockatoo, Psittacus cristatus

735 Rhamphastos momota, Brasilian molmot, rare

'736 Heron, male, Ardea major

737 Goose, N. America

738 Long-legged Plover, m. and fem. Charadrius Himantopus, rare

739 Falco Ossifagus, and a Night Raven, Ardea Nycticorax

740 Curlew, Cape of Good Hope; Tantalus calvis, rare

741 Purple Water-hen, Fulica porphyrio, S. America; Grous', Hudson's Bay, two cases 
742 Gray Gull

743 Cinnamon Sparrow, European Nut-hatch, Sitta Europea: Nun Titmouse, male; Cheveril Goldfinch, four cases

744 Snipes, two specimens; Java Sparrow, Mungrel Canary; brown Water-hen, and another, five cases

745 A remarkably fine specimen of the common Peacock, Pava cristatus

746 Cushew birds, Crax Pauxi; two fine specimens, male and female, rare

747 Spotted Shag, Pelecanus punctatus, New Zealand, rare

748 Pochard duck, m. and ferm. Anas Ferina; Shoveler duck, Anas Clypeata, m. and fem. 2 cases

749 Spongia Infundibuliformis, affixed to a pecten

750 Two curious sponges, spongia cellulosa, and cat's-tail sponge; Gulph of Florida

751 An elegant specimen of gorgonia pretiosa, with adhesions of serpula

752 Madrepora hirtella of Pallas, rosy stellated coral, front Providence Island

753 Scarce deep, or conic variety of madrepora fungites, East Indies

754 Madrepora fungites, the flat variety, a fine specimen

755 Madrepora papillosa, branched nipple coral, East Indies 16

756 Madrepora fascicularis, Linn. from the Mauritius Island, large and fine

757 Madrepora sinuosa, broad-ridged brain-stone, fine, West Indies

¡58 Red gorgonia, Sicily; and curious yellow gorgonia, Gulph of Florida

759 A most beautiful specimen of madrepora ramea, or May blossom coral

760 A hollow Hint, having the cavity coated with chalcedony $/ 3$

761 Antimony, crystallised, Germany 1 th

-62 Molybdate of lead, Carinthia; finely crystallised/green phosphate of lead, and a white lead, Scotland $10 / b$

763 Ruby silver, crystallised, from Hartz

764 Crystallised manganese on barytes, Germany ; two sinaller specimens of ditto, and a calamine $10 \mathrm{w}$

765 Crystallised antimony, and another, crystallised arseniate of cobalt in quartz, Spelter; solid ore of nickel, with green nickel

766 Two very finely crystallised blends, needle antimony on quartz, native quicksilver in an ore of cinnabar, compact blend, and dendritical bismuth in quartz, and native orpiment, Turkey

767. An elegant specimen of dendritæ, on yellowish laminated marble, Germany 
768 Three mochas, one having red dendrites, and a cut specimen of the great Leverian chalcedony $15^{2}$

769 Nagoo, or spectacle snake, Coluber Naja, from the East Indies-an excellent specimen

770 Largest Tarantula spider, two curious and another, in three bottles

771 Exocætus volitans, or flying fish, Pleuronectes; and a silurus

772 Gobius minutus, Sygnathus Hippocampus; a small Exocætus, ancther-fish, and two lizards

773 Two-headed chicken, elegant double-banded snake, and an Exocætus volitans

774 Sygnathus Hippocampus, a juius, spider, fishes, \&c.-in six bottles

775 Scolopendra morsitans, three fishes, and another, in five bottles

776 White hare, Norway

777 Muræna Helena, a fine specimen

778 Sphinx lineata, and sphinx atropos

779 Eight sphinges, \&c. chiefly from Brazil

780 Black hare

781 Noctua Odora, Jamaica

782 Sphinx, Carolina; and two more, North America

783 Sphinx ligustri, lineata, and five others

784 Sphinges, eight specimens

785 Thirteen specimens of lepidoptereus insects

786 Sphinx Celerio, and seven other sphinges, North America

787 Carabus sex-maculatus, India; Cetonia insects, D. New Holland; and several Phalænæ

788 Phal. hastata, Gamma, Plantaginis, and twenty-six others

789 Twenty-two insects, various

790 Phalæna Cecropia, a pair, N. America

791 Thirty-one various insects

792 Phalæna moacha, Hebe; Caja, and seven others

793 Noctua Strix, very rare

794 Fourteen specimens of Phalænæ, including a good specimen of Phal. Fraxini

795 Phalæna Hebe, crimson under-wing moth, rare, Phal. Villica, and six others

796 Phalæna Bubo, and four others

797 Madrepora fungites, a small and elegant specimen, millepora cærulea, millepora truncata, and another

798 Madrepora annularis, and a millepora, naturally affixed to a shell

799 Red variety of the Sicilian gorgonia, the stem of another, divested of the bark, millepora muricata, and another 8

800 Two curious varieties of Tubipora musica, and a specimen of millepora foliosa 
801 Madrepora fungites of singular double growth, very curious

802 Madrepora bulliens, millepora truncata, and another $4 / p$

803 Madrepora labyrinthica, a fine specimen

804. Cat's-tail sponge, branch of gorgonia verrucosa, and four others

805 Spongia infundibuliformis, a large specimen

806 A large marbled senectus (Turbo marmoratus Linn) partly uncoated, and the great oriental triplex

807 A purple-ridged trochus, from Nootka Sound; and two pink dolphins, all rare

808 A large and fine thorny snipe, a scarce oriental buccinum, and a pigs' snout trumpet

809 The boat melon, Guinea; and long-clawed varieties of the spider strombus, Tranquebar

810 A triangular buccinum, an urn melon, and an oriental triplex

811 Two black scoops, New Zealand; two small zebra trochi, a panther helmet, and a pheasant snake

812 A knobbed trochus, Arabia; a cuma julipa, and a bulls'mouth helmet

813 The purple variety of the variegated spondylus, South Seas; the leolohendra strombus, Madagascar, rare'; and a spider strombus

814 The ridged helmet, Sicily; a young knobbed trochus, Red Sea; the waggon road scoop, Ncw South Wales; and a banded tun, China

815 Section of a large spotted melon, China; and an alatus gigas, W. Indies

$\$ 16$ A pigs' snout buccinum, a spotted melon, and a silk brocade cone

817 The great brown melon (voluta fesso Soland.) Guinea

818 A large wentletrap, or winding ladder, (Turbo-scalaris) Sumatra, very rare $3-3-6$

819 Acicular baroselenite, Germany; dendritical mica, Spain; celestine, Bristol; Shiller's spar, Hartz; two Bristol strontians, and two others

$820 \mathrm{~A}$ very fine and rare specimen of delicate green oxyd of nickel, Hesse

$$
\{=0-0
$$

821 Mass of brilliant/crystallised gray cobalt, ditto; very fine and rare.

822 Beautiful white chalcedony in minute bubbles, Germany; and finely coloured ditto, Cornwall

823 Dark red ore of quicksilver, Idria; aud phosphate of lcad, in minute light green crystals, Saxony

824 Black stalactitical iron ore, with very finely crystallised manganese on the surface

825 Magnetic iron, or loadstone 
826 Iridescent bubbled iron, Triers, two specimens; and a piece of manganese

827 A specimen of barytes, and spathose iron, singularly fractured, one side representing a grotesque human head; and a stalactitical iron

82.8 Black bubbled iron ore, a fine specimen, Triers

829 Stellated manganese, Triers

830 A beautiful sardonyx with darkly-coloured spiculæ pervading part of its substance, an ocellated agate pebble, Scotland, small pellucid agate

831 A fine piece of chalcedony, part of No. $1560 /-2-6$

832 Five various specimens of quartz, and a curious flint

833 Onachine rock salt, being a stratum of red passing through a bed of white salt

834 A fine red cornelian, three mochas, and an agate $-1 /$

835 Quartz crystal, Saxony; and two others

836 Fine specimen of red stellated antimony, Hungary; and crystallised zeolite, Hesse $-10=$

837 Red zeolite, Sweden; and crystallised phosphate of lead, Saxony

838 A very beautiful pellucid specimen of hyalite, Franckfort

839 Fine specimen of shining calcareous earth (Glauzerde of of the Germans,) Hesse ; and dove-coloured porcellain jasper, ditto

840 A highly pellucid specimen of Brasilian rock crystal, containing an elegantly and curiously formed group of spicular crystals, having the appearance of antimony, and which are supposed to be Titanium $\eta=2-0$

End of the Seventh Day's Sale. 


\section{EIGHTH DAY.}

Tuesday, the 12th of May, 1806.

841 W a $\mathrm{R}$ club, new Caledonia; ditto, Friendly Islands

842 Cordage of the touta, or cloth tree, Sandwich Islands; fishhook and mirror, from ditto

843 Curious necklace of cowry shells, ditto

844 Breast gorget, shark's tooth instrument, bracelet, and feather necklace, Sandwich Islands

845 Curious minute shell necklace, boars'-tusk bracelet, and sharks'-tooth instrument

846 Fur boots, Cook's River; and gloves, from ditto

847 Rattle, shaped like a bird; and model of a canoe, Nootka

848 Richly carved war club, Friendly Islands

849 A very curious feathered idol, ornamented with hair, Sandwich Islands

850 A feathered helmet and a fly flap, ditto

851 Spear, ornamented with seals teeth, Nootka; and very large spear, Sandwich Islands

852 Ancient English breast plate and helmet

853 Ancient English hauberk

854 Hammock, made of grass, Spanish main

855 Elegant fan, formed of the feathers of rare and beautiful birds, Brazil

856 Large ornamented leathern coat, Canada; said to have been presented to General Wolfe

857 Leathern shirt, Hudson's Bay ; and part of a rifle man's dress, N. America 
858 The Ten Commandments, written in the compass of a shilling, elegantly framed and glazed

859 A specimen of gold chair, the links of which are singularly fine and delicate

860 A representation of the head of St. Paul, beautifully executed in cut paper, framed and glazed

861 Curious German sword, having a complete calendar in that language on its blade

862 Very fine specimen of penmanship, by Mr. Tomkins, framed and glazed

s63 A "Vive la Plume," by the celebrated Mr. Brown, of Norwich

864 Scoter duck, $m$. and fem. and hybrid pheasant-two cases

865 Orange crowned green finch, S. America; white throat; tringa pugnax, mas; reed sparrow, m. and fem. and sky-lark, male-five cases

866 Brown crested heron, N. America

867 Wire-tailed martin, N. America; petrel, America-two cases

868 Wild goose, Canada, anas Canadensis, one specimen, without case

s69 Mottled Turkey, m. and fem.

870 White fronted goose, anas albifrons; large gray gull-two cases

871 Lesser speckled loon, scaup duck, guillemot, and turbit pigeon-four cases

872 Buzzard hawk, falco fasciatus, N. America

873 Pheasant, S. America

874 Brown heron, ardea caspica, Africa

875 Crested grebe, Colymbus cristatus; gentle falcon-two cases

876 Eider duck, male, anas mollissima

877 White peacock, pavo cristatus var.

878 Penguin, Patagonia; Aptenodytes Patachonica

879 Great spotted owl, strix nyctea, var striuta, Hudson's Bay

880 'Turnstone, Hudson's Bay; Virginia nightingale - two cases

881 Anas occidua, Kamschatka

882 Corvorant, velvet duck - two cases

883 Blue and white fronted parrot; bunting, variety; wood pigeon; and bald buzzard hawk-without case

884 Chinese joss

885. Singular Chinese ornament, being wood which has grown in the shape of an ewer and stand

886 Large portrait in oil of an horse, (said to have belonged to the Landgrave of Hesse,) having a tail and mane of uncommon length

887 Water-colour drawing of the interior of the Leverian $\mathrm{Mu}$ seum, by Mrs: Smith, (late Miss Stone) 
888 A gilt frame, glazed, containing shins of various North American snakes, \&c.

889 A curious flint of a dark colour, clouded with grey, the lat7. ter resembling a begging figure on his knees; an Egyp- tian pebble, and two variegated cornelians

890 Crystallized white carbonate of lead, on hxmatite; and ditto, on green carbonate of copper, Hartz forest

891 Nine specimens of fluor, among which are, green fluor, Cornwall, topazine fluor, amethystine fluor, and fluor with internal linear appearances

892 Quartz crystals in the cavity of a specimen of basaltes, Hesse, extremely scarce

893 Water colour drawing of the Elk, by Catton, framed and glazed

894 Representations of insects in shell-work, framed and glazed; and stained marble, representing a cucumber

895 Remarkably fine dissections of leaves, by Mr. Dobson, framed and glazed

896 Sphinx polymena, carabus fulcatu, cimex spensus, and sixteen others

897 Cerambyx rubus imperialis, Africa, rare buprestis fascicularis, \&c.-in all nineteen

898 Cetonia hirta, curculio spectabilis, silpha surinamensis, curculiones, \&c.-altogether eighteen specimens

899 Cicada dimidata, reduvius dentatus, and twelve more

900 Buprestis fasciculatus, cerambyx rubus, uni fasciatus, \&c. two curious pupæ of cicadæ, and eleven more

901 Cerambyx bifasciatus, a large curculio, a curious carabus, and nine others

902 Buprestis fascicularis, cetonia hirta, mylobris cichoreii, several exotic bees, \&c.--eighteen specimens

903 Papilio iris, and eight other insects

904 Bombyx verscolora, fem. Phalæena fraxini, monacha and tau

905 Phalæna versicolora mass, monacha, Hebe; and five others

906 Papilio levana, phalæna tau, and six other various

907 Phalæna fraxini, and phalæna monacha, both sexes

908 Eleven various lepidopterous insects, chitfly phalænæ, from Germany

909 Phalæna tau, male, gramanica, papilio iris, levana, \&c, -in all thirteen specimens

910 Noctua Strix, rare

911 Noctua fraxini, rare; villica, bucephala, and eight others

912 Isis hippuris, a large and fine specimen

913 Spongia infundibuliformis, gorgonia verrucosa, two of the gorgonia flabellum, and another

914 Red and yellow gorgonia, gorgonia flabellum, an elegant specimen; and two curious sponges 
915 Gorgonia verrucosa, with the swallow-tailed oyster attached' and two others

916 Curious sponge, inclosing a number of mya vulsella, and the warted sponge

917 Spongia digitata, curious branched or fingered sponge, and spongia infundibuliformis

918 Madrepora papillosa, branched nipple coral, East Indies

919 Two branches of gorgonia flabellum, or sea fan, (the purple variety) and a gorgonia fusca, naturally affixed together on a fragment of coral, West Indies

920 Cats'-tail sponge, Gulph of Florida ; and another curious, foliated variety of millepora alcicornis, and the warted gorgonia

921 Curious specimen of the basis of a red coral, from the coast of Sicily, star-stone coral (annularis of Ellis,) and two of gorgonia flabellum, one with the flesh, and the other divested

922 Millepora foliacea, Ellis, an interesting specimen, formed upon the shell of an oyster

923 A purple spondylus, Sicily; and one valve of a spondylus

croceus, with serpulæ, \&c. on a madrepore, W. Indies

924 A cuma tulipa, of extraordinary size, and a large bull's. mouth helmet

925 Two spider strımbi, Madagascar; and an occidental trumpet

926 An endive purpura, a carrot cone, and a conus mustelinus

927 The marbled melon, Guinea, rare; the thorny snipe purpara (Murex brandaris Linn.) Meditcrranean; and a porpoise buccinum, W. Indies

928 A fine nereid's trumpet, (Bucc. Tritonis) Solander, W. Indies

929 Two of the tapestry cuma, the tuberculated scoop, two helmets, and an alatus

930 The black mother-of-pearl shell, Sandwich Isles; and a fine spider strombus

931 A spotted melon, and an alatus gigas

932 Rhombus tuberosus, China; Murex vasa, $W$. Indies; a section of a cone, a plough alatus, and three others

933 A fine antique purpura, two occidental triplices, two purse helmets, and an uncoated trochus

934 A purple-ringed trochus, from Nootka Sound; and two pink dolphins, all rare

93.5 The orange-striped, the marble pavement, and another helmet, a striped fig, the fine mouth scoop, and the thicklipped frog

936 The large brown European tun (buccinum galea Linn.) Sicily

937 The Holland flag chersina, a scarce asperated rhombus, and a reverse chersina-all rure 
938 A knobbed rhombus, a butter-firkin cone, a granulated helmet, and a small bull's mouth helmet

939 The urn melon, a zebra alatus, and a ramose triplex

940 A spotted melon, and a Mediterranean tun

941. The flag cone, an undulated helmet, and a small bull's-mouth helmet

942 The tiger cone, rare; a striated cone, and knobbed sun shell

943 Nine specimens of marcasite amongst which are a fine polished Pedra Ynca

944 A singularly fine specimen of brilliant dendritic ruby silver, Hartz forest-extremely rare

945 Beautifully iridiscent hæmatite, iron ore, Triers; and dendritical cobalt, Hesse-rare

946 Six variously crystalized marcasites, small natilus pervaded with pyrites, and another

947 Elegant specimen of radiated sattin-like malachite, Siberia ; and marcasitical copper ore, between two bands of iron ore

948 A fine specimen of brilliant crystallized gray ore of cobalt, Hesse

949 Schaumerde, Hesse, rarc; two varieties of sulphate of strontian, Bristol; and another

950 A beantiful specimen of the ultramarine variety of labrador Feldspar, rare

951 An oval snuff-box, formed of a mass of fine garnets in a micaceous bed

952 Native tin, with quartz crystal imbeded in it, Cornwall, ex tremely rure

953 Dendritical cinnảbar, Deux Ponts; antimony, and arsenic

954 A curious small box and cover, made of amber

955 Amber, with an insect of the moth kind, Dantzic; and a piece of gum copal inclosing a small species of blatta, and two leaves, from the East Indies

956 Nummular twelve-sided spar, with bitumen, Derbyshire

967 Calcareous spar, in clusters of hexagonal crystals, tending to a three-sided pyramid

958 Earth and clay, containing particles of gold, from the running waters of Backet's mine, near Chemnitz in a small bottle; and another containing gold earth, from Treves

959 Gray silver on crystallized quartz, with resin-coloured blend, native silver in hornstone, and silver in barytes, Hartz

960 Vitreous silver, a large specimen

\section{End of the Eighth Day's Sale.}





\title{
Catalogue
}

\section{चय \\ LEVERIAN MUSEUM, \\ PART II. ofoqua yma is}

INCLUDING THE SECOND EIGHT DAYS'SALE.

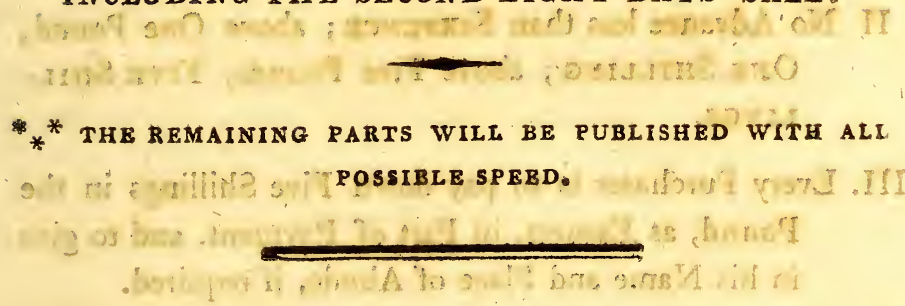

THE $S A L E$

OF

\section{THE ENTIRE COLLECTION}

\section{(By Messrs. KING and LOCHEE,)}

\author{
WILL COMMENCE
}

On Monday, the 5th of May, 1806, at Twelve o'Clock,

In the Building now occupied by

\section{THE MUSEUM.}

The three Parts of the Catalogur already published, (Price 2s. 6d.) to be had at the Museum; at Messrs. King and Lochée's, (the Auctioneers) and at Hayden's Printing-Office, Brydges-Street, Covent-Garden.

Hayden, Printer, 4 , Brydges Street, Covent Garden. 


\section{CONDITIONS OF SALE.}

I. THE highest Bidder will be declared the Buyer; but if any Dispute should arise, the Lot must be put up again.

II. No Advance less than Sixpence; above One Pound, One Shilling; above Five Pounds, Five ShilLINGS,

III. Every Purchaser is to pay down Five Shillings in the Pound, as Earnest, in Part of Payment, and to give in his Name and Place of Abode, if required.

IV. The Lots to be removed, at the Expence of the Purchasers, within one Day after the Sale; and the Remainder of the Purchase-Money to be paid on or before the Delivery,

V. Upon Failure of complying with the above Conditions, the Money deposited in Part of Payment shall be forfeited. All Lots uncleared within the Time aforesaid, shall be re-sold, by public or private Sale; and the Deficiency (if any) attending such Re-sale, shall be made good by the Defaulters a this Sale.

Gentlemen who cannot attend the Sale, may have their Commissions faithfully executed, by their humble Servants,

King and Lochée. 


\section{NINTH DAY.}

Wednesday, the 13th of May, 1806.

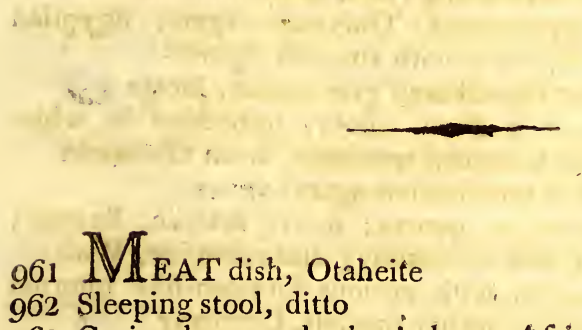

962 Curiously carved egboe's horn, Africa

964 Gilt spurs, resembling those worn by the Knights of the Bath

965 Ivory beater, China. Its use is to strike a Irum, by which various public notices are given

966 Real tomahawk, and tobacco-pipe in one

967 Ancient English battle-axe

968 Finely carved war-club, Friendly Islands

969 Oriental musical instrument

970 A small copy in Terra Cotta of the celebrated figure of Moses, by Michael Angelo

971 A fine specimen of the Jamaica sugar cane

972 A ditto of the Otaheite sugar cane

973 Large Rhinosceros horn

974 Largest weasel

975 Gray variety of the common hare, Lepus timidus

976 Coati mondi, Viverra nasua

977 White variety of rat, and fawn-coloured variety of mousetwo cases

973 A fine specimen of the musk-shrew, Mus pilorides, very rare 979 A fine specimen of Brasilian crystal, with singular internal - moss-like appearances, arising chiefly from chlorite $x-10$ 980 Needle-like manganese, and crystallized blue chalcedolyy 
981 Zeolite, and molybdate of lead 12

982 Accinite, a fine specimen, Norway

983 Needle-antimony, and a specimen of brilliant marcasite

984 Foliated native gold, Transylvania $-3=0$

985 Vitriolated lead crystallized, Anglesea

986 Compact blend, manganese in octoedral crystals, and an ore of arsenic, Hungary

987 Foliated native gold, and Nagaya gold

988 Iridiscent needle-antimony ; antimony, Tuscany; an ore of arsenic ; and wolfram, Cornwall

989 Ruby silver ore, crystallized; and-galena, combiaed with silver, grey silver, and crystallized quartz

990 Transparent agate, exhibiting remarkable reticulated mosslike internal appearances; Oberstein agate, Egyptian pebble, and an heliotrop with singular figures

991 Large and very fine crystallized gray cobalt, Hesse /

992 Ocellated agates, of a flesh colour, imbedded in white quartz, a fine and beautiful specimen, from Oberstein

993 A grand specimen of fortification agate

994 Crystallized titanium, in quartz; native arsenic, Saxony; crystallized grey cobalt, Saxony; and calanine, Wales

$9 g 5$ Large oriental mocha, with curious blossom-like internal appearances, and nine other mochas, Germany

996 A specimen of iridiscent labrador Feldspar, richly variegated with regal purple, apple-green, and blue. This combination of colours in labrador is extremely rare

997 Six specimens of copper, among which are red ruby copper, Siberia; blue crystallized carbonate of copper, Bannat: and four others -4.6

998 A most beautiful specimen of delicate bluish green, bubbled, calcareous deposition, tinged by nickel; ; and crystallized zeolite, in basalt, from Hesse

999 A remarkably clear slab of polished fluor, exhibiting internally cubes sprinkled with marcasites

1000 Marcasites, partially coating calcareous spar, with dog's tooth, and pearl spar; brilliant bubbled marcasites, and fluor, with marcasites

1001 A large and fine specimen of brilliant gray crystallized cobalt, on ponderous spar, which is partially tinged redHesse

1002. Cinnabar, rich in native mercury; ditto, Germany; and crystallized phosphate of lead, Saxony $-\mathrm{h}$

1003 Crystallized gray copper, ditto iron, solid uinnabar, ditto gray cobalt, blue copper ore, pink calcareous deposition, and rose-like gypsum, Hesse 12 .

1004 A small but well-defined four-sided Basaltic column, with olivin adhering to it, Hesse; and a specimen of nodulas basalt, rare, from ditto 
1005 The great cockscomb oyster, (mytilus hyotis, Linn.) from the Friendly Islands

1006 Two baciger alatæ shells, Madagascar ; four olives, a frogshell, and two more

1007 An uncoated sulcated sun-shell, with a large serpula on it, New Zealand: the box-wood cone, two orange-mouthed olives, a black music, Guinea; and four others

1008 The great helmet, West Indies; and a large peacock helmet, from Guinea

1009 A fine group of serpula lumbricalis, and a large mytilus rusticus, with adhesions of serpula, triquetra, and balaniEnglish Coast

1010 An echinated sun, West Indies; two bat volutes, two gibbous olives, and four others

1011 Two musics, five olives, and two ribband alatæ

1012 A camp olive, Panama; the grey oriental olive, China; and a lirge black music, Guinea

1013 The filleted scoop, the argus frog, a large red granulated trochus, the partıidge helmet, a monk's cowl limpet, and a scarlet-mouth alatus

1014 Two orange-mouth olives, China; a scarce oriental triplex, two bat volutes, and a bezoar helmet

1015 An uncoated sun, from Nootka Sound; another, West Indies ; two cones, and five others

1016 A fine lightening music, from Japan, very rare $/ 3$

1017 Kanguroo, young, in a glass case

1018 Phoca vitulina, common seal

1019 Pleuronectes roseus

1020 A specimen of the cashew-nut, with the fruit, skeleton pear, and ditto cherry - in three bottles

1021 The coriaceous tortoise, testudo coriacea, a large specimen, Dorsetshire coast

1022 Lacerta gangetica, the gangetic crococodile, rare

1023 Striped rattle-snake, crotalus horridus, stuffed

1024 The guana lizard, lacerta iguana, a large stuffed specimen, and a young ditto

1025 A large and fine specimen of the common cuttle fish

1326 Two well-preserved larvæ of a curious species of phasma, a spinous larva of a lepidopterous insect, and anotherin three bottles

1027 Mantis oratoria, two singular caterpillars, a locust, and 2 spider-in five bottles

1028 Chimera monstrosa, North Seas

1029 A suffed specimen of lacerta Dracæna, America

1030 Siren Lacertina, from South Carolina, a large stuffed spe. cimen

1031 Stannel hawk, E. Indies 
1032 Superb warbler, Botany Bay, Sylvia superba

1033 Violet tanager, Tanagra violacea, under a bell glass

1034 Green certhia, ditto

1035 Wattled bee-eater, Merops carunculatus, Botany Bay

1036 Ditto fem.

103' Psittacus militaris, excuted in the feathers of the bird, after the manner described by George Edwards; framed and glazed

1038 Pink-breasted oriole

1039 Bucco Cayennensis, m. and fem. rare

1040 Magpie, corvus pica, and two specimens of the tumblerpigeon

1041 White-throated finch, Africa, $m$, and fem.

1042 Long-tailed Whidah bird, Africa, Emberiza paradisaa

1043 Virginian horned owl, Strix Virginiana

1044 Royston crow, corvus cornix

1045 Arctic gull, Larus parasiticus, Greenland

1046 Emberiza imperialis, South America

1047 Bittern, N. America, Ardea vittata

1048 Falco lagopus, rough legged falcon. This specimen was shot in England

1049 White variety of the rook, and a wood-owl

1050 Psittacus obscurus, South Seas, very rare

1051 Seven impressions of plants, various

1052 Curious cast of an ammonite $y$ te

1053 Various impressions of the stems of plants, three specimens, with the counterparts

1054 Six various impressions of ferns, from Colebrooke Dale, and Nottinghamshire

1055 Stem of a large plant, imbedded in grey sand-stone, and its counterpart, Lancashire

1056 Pine cone in an iron nodule

1057 Large stem of a plant of the reed kind

1058 Large stem of a plant, in sandstone, Lancashire

1059 Impression of a fern in stone, large and curious

1060 Four fragments of ammonitæ, three very brilliant, having the inner or pearly coat

1061 Part of a spined echinus in flint, another small, in sandstone, and fragments of a mamillated echinus, and the spines in flint

1062 Cast of an ammonie, in a nodule, and its counterpart, and another with a singularly compressed fragment

1063 Four impressions of ferns, in iron stone, and two singular leaves 1 let

I064 Two fossil ammonites, and a nautilus

1065 Four impressions of ferns, in iron stone, and two of leayes

1066 Two sections of an ammonite, cut and polished 
1067 An echinus in chalk, with fragments of two long spines, and some smaller, supposed to belong to the same animal, or another of the same species

1068 Tabular barytes, very finely crystallized on quartz, Hungary

1069 An uncommonly fine specimen of dendritical cobalt, the dendritæ remarkably large, very rare-Hesse $1-2=-13$

1070 Hair-like gypsum, Derbyshire $s / 1$

1071 A very rare variety of Siberian iridiscent feldspar

1072 Eleven various agates, .\&c.

1073 Fine slab of mocha-stone, and a specimen of Lux Sapphiri, Hungary

1074 An inlaid oriental agate, and an agate seal inscribed with Turkish characters, which belonged to the late Hon. Wortley Montagu

1075 Crystal seal, a sardonyx, both oriental, and three mochas $/ 20$ 1076 Delicate crystallized olive green phosphate of lead, Siberia

1077 A fine specimen of wood tin, shewing part of the bubbled external covering, rare $-1-1-5$

4. 1078 An elegant oval agate cup

$1079 \mathrm{~A}$ beautiful and large specimen of rose-like gypsum, Germany, rare

1080 A large jaspachtes snuff-box, mounted

End of the Ninth Day's Sale. 


\title{
TENTH DAY.
}

\author{
Thursday, the 14th of May, 1806.
}

$1081 \mathbb{R}$ ASP made of the skin of the ray-fish, and a chissel of basalt, Otaheite

1082 Specimen of cordage, from ditto, and a tattooing instrument

1083 Fish decoy, formed of parts of different cowry shells, from ditto, and a fish hook, \&c.

1084 Idol, from ditto; and a tattooing instrument

3085 Nose flute, from ditto, and a necklace

1086 Syrinx, or Pan's reed, from ditto; and a necklace

1087 Dress made of sea lions skin

JGS8 Elegant cap of a mandarine, China

1089 Robe of ditto

1090 Turkish pipe, with valuable jasamine tube

1091 Gigantic briar, Straits of Malacca

1092 Remarkably large bambon, E. Indies

1093 Sea cocoa nut

1094 Runic almanac

3095 Small Chinese gong

1096 Great snipe, scolopax major, shot in England, without case 1097 Banksian cockatoo, psittacus Banksii, New Holland

1098 A fine specimen of the white magpie

1099 Green-winged dove, E. Indies, Columba Indica

1100 White partridge, and variety of the Tringa pugnax

1101 Yellow-bellied parrot, Brazil

1102 Reed sparrow, m. and fem. black cap, m. and fem. and inttrel-three cases 
i 103 Curasso bird, m. and fem. Crax Alector

1104 Lesser bunting, $m$. and fem. and picus viridis, $m$. and fem. -two cases

1105 King woodpecker, N. America

1106 Certhia fusca, South Seas, extremely scarce

1107 The common magpie, corvus pica, and fire-eyed grebe

1108 Long-tailed dove, S. America

1109 Lanius sulphuratus, yellow-bellied shrike, Guinea

1110 African heron, Ardea Caspica, shot in England

1111 A very finely preserved specimen of psittacus ararauna, Brazil

1112 Four alatæ, an uncoated rugose sun, and four others

1113 A large devil murex, a leopard cone, and a striated cone

1114 Conus notabilis, rare; the false high admiral cone, and a waved emerald sea snail

1115 A small but fine voluta nobilis, Linn. in a young stage of growth, from China, very scarce

$1116 \mathrm{~A}$ girdle cone, two orange-mouth olives, an antique purpura, and five others

1117 The great violet serpula, West Indies; a group of serpulæ, Sc. on a gorgonia, ditto; a curious hermit crab, in a snake shell, South Sexs; branch of a mangrove bush, with adhesions of balani, and a group of tulip balani

1118 Cochlus singularis, in a young state of growth, New South Wales; a group of serpula filigrana, a scarce sun, South Seas; and a large nerita of a rare kind, Isle of Cocoas

1119 A large and fine camp olive, (voluta porphyria, Linn.) from Panama

1120 A beautiful undnlated variety of the magpie apiculum, West Indies; the pomegranate sea snail, uncoated. from the Cape of Good Hope; and a scarce sulcated sun, New Zealand

1121 The oriental purple-mouth alatus, very rare; and two of a scarce variety of the gibbous olive, from China

1122 A large flag cone, (conus capitaneus, Linn.) South Sea; and two helmets, (the undulated and plaited) West Indies

1123 The great cockscomb oyster, Friendly Islands

1124 A large magpie apiculum, West Indies; and two scarce species of senectus, from Madagascar

1125 The great high admiral cone, two inches and a half in length, Friendly Islands, very rare.

1126 The variegated spondylus, Friendly Isles; and a scarce margaritifera, New South Wales

1127 A fine conus monachus, the imperial crown cone, and a short-spired devil murex

$\$ 128$ The pigeon's egg lamp bivalve, with adhesions of curious serpulæ, Minoria; and two scarce banded West India olives 
1129 The black tiger cone, the night admiral cone, and a fine endive purpura

1130 A scarce gryphus, with another of the same kind attached to it, South Sea ; and a fine purple spondylus, Sicily

1131 The pink-mouth black trochulus, Cape of Good Hope; a scarce sun, South Sea; an uncommon nerita, Isle of Cocoas; chiton aculeatus, South Sea; and two cones

$1132 \Lambda$ fine argonauta argo, Linn. or wrinkled paper sailor, Minorca, rare

1133 A very large purpura rubicunda, with a fine mouth, Guinea, very searce

1134 Voluta elongata, and orange-mouth long ear-like land shell, New Caledonia, very scarce

1135 Guinea pigs, Cavia porcellus, m. and fem. and young; and hedgehog, m. and fem. and young, Erinaceus Europeus

1136 Fawn of fallow deer, Cervus Dama

1137 White variety of hedge-hog, Erinaceus Europeus

1138 Arctic fox, Canis lagopus

1139 Badger, Ursus meles

1140 Opossum, Surinam, Didelphis dorsigera, with young .

1141 Roebuck, Cervus capreolus, Scotland

1142 White porcupine, Canacia, very rare, Hystrix dorsata

1143 Marten, fem. mustela martes

1144 Spanish lap-dog

1145 Monkey, Africa

1146 Lion monkey, Simia ferox, very rare

1147 Lesser baboon

1148 Small red monkey, Simia Beelzelul, rare

1149 Small black ditto, Africa, Simia midas

1150 Monkey, St. Jago

1151 Small black-legged monkey

1152 Very large specimen of septarium, Somersetshire

11.53 Hornet's nest, E. Indies

1154. Very large and capital specimen of fossil-wood, with minute quartz crystal, Wiltshire, weighs above $2 \mathrm{cwt}$.

1155 Large mass of fossil oysters, in Limestone

1156 Three specimens of ammonite, and transverse section of another

1157 A beautiful impression of a fern, in argillaceous iron ore, and its counterpart

1158 Impression of a plant in iron stone, and its counter parts

1159 Five elegant impressions of ferns, in argillaceous iron ore, and the stem of a vegetable ditto

1160 Four specimens of cornu ammonis

1161 Cast of an ammonite, in calcareous stone, and another in pyrites

1162 Three various parts of plants, in argillaceous iron ore, and their counter parts 
1163 Lacerta monitor, var. and coluber doliatus

1164 Fossil nautilus, Sheppy Island, cut in two and polished

1165 Cast of an ammonite, in two parts, sprinkled with spar and marcasites

1166 Five specimens of echini, and two casts of the fragments of a mamillated kind, in all seven ?

1167 Nautilus cut in two and polished

1168 Very distinct impression of a ferm, in an argillaceous nodule of iron, with its counterpart $3-0$

1169 A sharp and well defined fern, in iron ore, with the counter part $\quad-6-6 *$

1170 Nautilus, cut in two and polished, shewing the siphunculus

1171 Cast of the interior of an anmonite, Bath

1172 Bones of a bird in calcareous stone, and a conterpart, from Stonsfield 4 .

1173 A large and fair impression of a fern in argillacepus iron ore

1174 An echinus in chalk, with four spines apparently attached

$2=$ to it, and fragment of another, with several clavated spines

1175 Impression of bark in iron stone, with its counter part

11-6 Siliceous manganese, Hungary; calcareous sand stone, Fontainbleau; arseniate of 'iron, and bubbled copper, Cornwall

1177 Argentiferous galena intersecting a blackish schistus, from Ramelsberg in the Hartz; and crystallized light green phosphate of lead, Saxony

11 is Tungsten, with white quartz and mica; delicately white bubbled chalcedony, Cornwall; bubbled copper, ditto; crystallized tin, ditto; gray copper, and hornblende in a silvery schistus, Spain

1179 Argentiferous galena, Germany; and resin-coloured blende, in large and fine chrystals, ditto

1180 A large and fine slab of yellow polished fluor

1181 A large mass of crystallized black blende, and a large T specimen of white quartz crystals, with purple fluor

1182 Crystallized carbonate of uranium, Saxony; calcareous sand-stone, Fontainbleau; ruby blende on galena, Hungary ; crystallized gypsum, Germany

1183 Octohædral fluor, two arseniates of copper, malachite, crystallized ruby copper, and crystallized tin, all from Cornwall

1184 Earthy black oxyd of cobalt, Hesse, rare

1185 Solid black oxyd of cobalt, on a ferruginous matrix, a fine and rare specimen, ditto

1186 A fine specimen of flos ferri, Germany

1187 Green fluor, with double-pointed quartz crystals coating the surface, purple cubic fluor, with bevelled edges, and four other cubic fluors, chiefly from Durham 
1188 White opal in the matrix, Saxony; and crystallized cinnabar, Deuxponts

1189 Crystallized adularia, Switzerland; and iridescent stalactitical iron, Triers

1190 Grey laminated iron ore, the eisen ram of the Germans, from Olomiz; and a bubbled iron cre, Saxony

1191 Two specimen's of red hæmatite

1192 Stalactitical iron, coated with white oxyde of manganese, rare

1193 A black hæmatitic iron ore, crystallised partiy in stalactittes, and a beautiful manganese, with a fine bubbled surface

1194 Amber, Dantzic; and three specimens of gum copal, inclosing insects, East Indiès

1195 A large quartz crystal, Switzerland; and four smaller

1196 Native sal ammoniac, on an argillacecus matrix, Siberia, extremely scarce; and green malachite, Cornwall

1197 A singularly beautiful and interesting specimen of orangecoloured vermicular chalcedony, a large and extremely rare article, from the East Indies

1198 A grand and most beautiful specimen of iridescent stalactitical iron, from Triers

1199 Muriate of silver, combined with native silver, Mexico, very rare

1200 A brilliant specimen of iridescent bubbled iron, from Triers, Germany

End of the Tenth Day's Sale. 


\title{
ELEVENTH DAY.
}

\author{
Friday, the 15th of May, 1806.
}

201 MBRELLA hat, Brazils

1202 Saw of saw fish

1203 Singularly carved stick

1204 Dish, made anno, 1688, with satirical devices on the dress of that period

1205 Chinese compass

1206 A large spontoon, Persia 16

1207 Crown in which the King of Brach in Africa was killed

1208 Large meat dish, Otaheite

1209 Oriental musical instrument

1210 Persian target 2

1211 Very long hollow tube for discharging arrows, with three of the arrows

1212 Ivory sceptre of the king of Senegal / 2

1213 Three specimens of echini, two in chalk, the third detached 1214 Six various species of echini

1215 A large section of a nautilus/n calcareous stone $f$

1216 Fossil nautilus, cut and polished, and an ammonite, Wiltshire, ditto $10-6$

1217 Part of the stem of a vegetable, in argillaceons iron, with its counterpart $1=18.0$

-1218 Three impressions of plants, two in argillaceous uron

1219 An ammonite and its casts, two specimens; impression of an ammonite, in spar, Gloucestershire; and another 12 
1220 Fossil nautilus, cut and polished, and an ammonite, ditto

1221 Part of an echinus, with spine, in chalk, and another specimen of chalk, with various fragments, and a third single spine $/ / 4$

1222 Large fossil nautilus

1223 Impression of ferns, in iron stone

1224 Three species of echinus, and part of the cast of another, in flint

1225 White carbonate of lead, Scotland; and calamine, Flintshire

1226 Finely crystallised galena, on quartz, Germany; threadveined galena, with spar and cauk, Eerbyshire

1227 Black oxyde of cobalt, Saalfeld, Saxony; and three specimens of antimony

1228 Curious tetraedral blend, intermixed with yellow quartz, from a tin mine, Cornwall

1229 Tin, in prism-form crystals, and three other specimens of crystallised tin

1230 Green fluor, with quartz, Cornwall; honey-comb purple fluor, purple fluor, with pyrites, and another

1231 Tin, crystallized, Cornwall; and another tir, from ditto, with copper, marcasite, quartz, \&zc.

1232 Tin, crystallised in large quadrangular prisms, and another tin, from Cornwall

1233 Two crystallised specimens of tin ditto

1234 Six small specimens of crystallised tin

123.5 Iridescent marcasites, coating calcareous spar, a large and fine specimen, Ecton, Staffordshire; greenish and patple fluor, coated with quartz crystals and marcasites

1236 Four specimens of turgsten, Cornwall, rare

1237: A very large slab, with a variety of vegetable impressions

1238 Three large fossil shells, namely a strombus, and two others

1239 Stem of a large plant of the reed kind, in sand-stone 9

1240 Impression of bark, and stem of some plant, apparently of the reed kind

1241 A murex, and two other shells, Hordwell Cliffs

1242 Fragment of a large plant of the reed kind, and two other plants

1243 Twelve crystals of tin, various

$1244 \mathrm{~A}$ fine and clearly defined vegetable impression in a nodule of argillaceous iron ore

1245 Twenty-one various crystals of tin

1246 Rarnose branches of some vegetable fossillised, three specimens, one of them inbedded in sand-stone

1247 Two young devil's-claw Strombi; a wrinkled ear, a nautilus, and three others

1248 Pecten maximus, a large shield pectunculus, the smooth clam, and two other bivalves 
1249 The undulated olive, from the Spanish $\mathrm{W}^{\top}$. Indies; four other olives, two cones, and two others

1250 The high-spired turnep, (voluta ponderosa, Soland.) $M a$ dagascar; an iris ear, New Zealand; a spider strombus, and a tulip cuma

1251 Cardium rusticum, Cepa versicolor, on a pecten, mactra - lutraria; mya arenaria and a Solen Siliqua-all English 1252 A spotted melon, a nautilus, a triplex ramosus, a variegated trumpet, and two others

1253 Two grimace buccina, two thorny frogs, an urn melon, a Chinese harp, and three others

1254 A scorpion strombus, two aculeated cassidulx, a pig's snout, buccinum, and two others

1255 A South Sea and two other snakes, a pink alatus, from Guinea; and two triplices, $W$. Indies

1256 A fine mole porcellana, China; the occidental argus porcellain, from Providence; and a fine cardium arundinosum, South Seas

1257 Threc groups of oysters of different species, on branches of mangrove, and some of the tree oyster on the stem of a gorgonia

1258 A fine bellied spindle, from Arabia; section of a bishop's mitre, Madagascar; and a rare screw, from China

1259 The reticulated frog, Sicily; a triangular buccinum, $W$. Indies; and three others

1260 A fine chersina tigrina, a scarce terrestrial shell, from Guinea

1261 A large wampum clam (venus mercenaria, Linn.) from $\mathrm{N}$. America; and two large and fine leopard porcellanæ, $S$. Seas

1262 Two harps, different, a pink-mouthed chersina, Surinam; part of nautilus pompilius, and two porcellana.

1263 A large Pinna rudis, Linn. from Guinea, rare

1264 Four scarce varieties of the haliotis genus, a groom cone; two breast-snails, and two others

1265 Fulimart, Mustela putorius

1266 Beaver, young, Castor fiber

1267 Tarsier, Lemur tarsier

1268 Hare, Java, Cavia agouti

1269 Bat. S. Seas, very rare

\section{MONKEYS GROTESQUELY SET UP.}

1270 The Family Baker

1271 The Family Barber

1272 The Family Milk Man

1273 The Family Porter 
-1274 Simia ferox, lion monkey, very rare

1275 Two specimens of the ptarmigan, Tetrao lagopus, Scotland

1276 White-fronted dove, S. Seas

1277 Pied pheasant

1278 Blue-breasted finch, America

1279 Gray-finch, m. and fem. Africa

1280 Falco ossifragus, a very fine specimen

1281 Missel thrush, and picus viridis, two cases

1282 Mountain goldfinch, Jamaica

1283 White variety of the common thrush

1284 Spanish duck

1285 White billed woodpecker, Picus principalis, m. and fem.

1286. Duck-winged game-cock

1287 Kestril, Falco tinnunculus, m. and fem. and young

1288 Barnacle goose, Anas erythropus

1289 Papilio serena, and twenty-two other papiliones, chiefly plel. urb.

1290 Papilio argus, phleas, \&c. thirty-four specimens

1291 Papilio proteus, and fourteen more

1292 Papilio argus, Euphrosyne, \&c. twenty-seven specimens

1293 Papilio malvæ, argus, phleas, \&c. nineteen specimens

1294 Razor bill, Alca torda

1295 Tufted duck, Anas fuligula

1296 Black-breasted red tail, Gibraltar, m. and fem.

1297. Crested auk, Kamskatcha, Alca cirrhata, vcry rare

1298 Jay, Corvus glandarius, and black cap, m. fem. and young

1299 Gray parrot, Africa, Psittncus erithacus

1300 A very capital specimen of the New Holland jabiru, Mycteria Australis

1301 Six specimens of cut and polished stones, among which are a beautiful red agate in quartz, and a large specimen of fortification agate

1302 A piece of labrador feldspar, exhibiting steel-coloured striæ, and having labrador-horn blend attached to it, and an elegant specimen of feldspar, having delicate striæ of gold and green colour

1303 Brilliant native cinnabar, in the matrix, Idria, and arseniate of cobalt, with stellated white arsenic, Hesse

1304 Calamine, with beautiful crystals of sulphate of lead, Hesse

$\$ 305$ Whitish cubic fluors, frosted with calamine, yellowish cubic flour, with galena crystallised, and a small specimen of amethystine flour, Derbyshire

1306 A large mass of fossil coral

1307 Six extraneous fossils, viz. parts of encrini, corals, \&c.

1308 Five ditto various, as parts of an asterias, \&c. 45 . 4

1309 Four fossil shells from France

$1310 \mathrm{~A}$ large and fine specimen of the loadstone, Siberia, rare 
1311 A piece of stalactical iron, with a very remarkable mammillated surface, Triers

1312 An excellent specimen of ditto, richly diversified with prismatic colours, Triers

1313 Three speciinens of amber, one containing a small insect of the ichneumon genus, and another, remarkable for internal appearances

1314 Laminated ruby silver on quartz, and native silver in quartz, cut and polished

-1315 A box formed of garnets in the matrix, very elegant -1

1316 Group of large cubic fluors, with bevelled edges, having marcasites within them, Derbyshire

1317 A most elegant specimen of copper ore, on a ferruginous basis, the upper surface being almost coated by delicate white mamillated calcareous spar, on which are dispersed brilliant light and dark blue malachites in crystals, and miunte bubbled green malachite, from Germany

$1318 \mathrm{~A}$ fine specimen of cubic marcasite, with a ferruginous coating, said to come from China. The same kind is brought from Peru, and is called by the Spaniards Piedra d'Ynca, or the Royal Stone

1319 Very fine and extremely rare specimen of arborescent cobalt, Hesse

\$320 Brilliant native cinnabar and pyrites in hamatitic iron, Idria; blue copper ore, Hesse; and solid green malachites, with vitreous and native copper, Siberia

End of the Eleventh Day's Sale. 


\title{
TWELFTH DAY.
}

\author{
Saturday, 16th May, 1806.
}

$1321]$ WO sections of a double cocoa-nut

1322 Persian bow

1323 North American wà-slub

1324 Remarkably long and straight root of ash

1325 Beautifuily grown stick of hazel

1326 Two curiously grown walking sticks

1327 Elegant African powder-horn

1328 Egboe's horn, Africa

1329 Various beautiful skins of North American serpents, in a glass fiame

1330 Double horns of rhinosceros

1331 A very capital and richly carved Meerschaum pipe

1332 Wood, curiously perforated by sea-worms, and branch of the cabbage-tree tied in a knot by monkeys

1333. Musical instrument formed out of a large specimen of cane, E. Indies

1334 Vase of Persian ware

1335 Curious specimen of ancient delf, with figures in las relicf

1336 Curious ancient dish, formed of mother of pearl, \&c. \&c.

1337 An extremely beautiful ewer, and stand of ditto

1338 Almanac, made anno 1432

1339 Curious Chinese wicker tea.pot

1340 Small Egyptian mummy

1341 Remarkably large specimen of the common hare, Lepus timidus 
1342 Viverra, S. America, myrmecophaga tetradactyla

1343 White lamb

1344 Fawn-coloured rabbits, $m$, and fem.

1345 Raccoon, Ursus lotor

1346 Fisher sable, N. America, Viverra Piscator

1347 Moschus grimia, very rare

1.348 Gray squirrel, N. America, two specimens; andNorway rats

1349 Otter, N. Anmerica

1350 Musk hog, Mexico, Sus Tajacu

1351 A fine impression of a fern, in an argillaceous stone

1352 An echinus of the mamiliated kind on flint

1353 Fragments of various spines, and parts of echini in chalk, three specimens /a is

1354 Ten various fragments, of serpulæ, pecten, \&c. in chalk

1355 Long spined pecten, in chalk, a curious trochus, and five mamillated echini

1356 Many-ridged nautilus, and part of a large ammonite

1357 Cast of a large trochus, reversed whelk, section of an ammonite, and two other shells

1358 Six various species of echinus, in chalk and flint

1359 An ammonite, a murex Hordwell cliffs, and two other shells

1360) Eight various impressions of plants $-2+12-6$

1361 Two impressions of vegetables $/-i-b$

1362 Curious impressions of ferns and other plants, six specimens

1363 Great winged spindle shell, Hordwell cliffs

1364. Three fossil impressions on sand stone if

-1365 Eight various echini, and two ammonites

1366 Three impressions of the stems and barks of some large plants fossillised

1367 Six echipi, in chalk and flint, various / 3

1368 Two beautiful specimens of jaspideous wood, Germany

1369 Three vegetable impressions, in argillaceous stone, Lancashire $/ / 4$

1370 Two spider strombi, an occidental trumpet, two tortoiseshell harps, and a large garnet limpet

1371 A large Medusa's head limpet, Barbary; the tent limpet, Cape of Good Hope; and a large cock's wing pectunculus, Ceylon

1372 A beaded fig, three porcellanæ, a large glycemeris, and a zebra alatus

1373 Three alatæ, different, one of them cut, to shew the internal structure; an indented oyster on a balanus; a herald's coat Cuma; and a pecten

1374 The chesnut Jandsnail, Jamaica; a large lúcerna, ditto; a striped apple-snail, E. Indies; two butter-firkin cones, a panther cone, with a gryphus adhering; and three others 
1375 Cardium rusticum, a young devil's claw, a glycymeris, a leopard porcellana, and two others

13,6 A large partridge tun, from St. Christopher's; and two large occidental argus porcellanæ, from Providence

1377 A fine chersina zebra, from the Cape of Good Hope, rare

1378 Two large oriental olives, an echinated sun, two musics; and a trochus

1379 The woodcock triplex, a thorny ditto, two slender ears, and a scarce long-beaked buccinum

1380 The great umbilicated breast snail, E. Indies; and two larǵe pink-mouthed chersinæ, Guinea

1381 A fine bishop's mitre, Madagascar; and two spotted dis. taff shells, Pulo Condore

1382 The great distaff shell, China, very rare

1383 Solen vagina, Linn. Tranquelar; the purple fluted mussel, Straights of Magellan; and the black tray, (Mytilus piceus, Soland.) Neu'foundland

1334 Conus arenatus, Madagascar; the moth's wing, or false Guinea Admiral cone; and a fine red-rnouth endive triplex

1385 Two musics, an occidental sun, a young scarlet-mouth alatus, and two orange-mouth olives

1386 A small but fine Voluta nolitis, very rare, from China

1387 The great nautilus of Asia, ornamented with a Spanish coat of arms and other devices

1388 The oriental music, (voluta elrcea, Linn.) and two large olives

1389 A large imperial sun, from Cloudy Bay, New Zealand, uncoated and polished, very rare

1390 Pine bullfinch, Hudson's Bay, and a certhia

$139 \mathrm{l}$ Very fine specimens of the ring-necked pheasant, phasianus colchicus, var. $m$. and fem.

1392 Common goose, m. fem. and young, beautifully preserved

1393 Buzzard hawk, male, and common pigeon

1394 Red and black-headed smew, English

1395 Two large specimens of hybrid geese, between the Canada and China breeds

1396 Tropic bird, Phaeton atherius

1397 Red-breasted merganser, m. and fem. Mergus serrator

1398 Spotted Falcon, N. America

1399 A fine group of ptarmigans, Tetras lagopus, seven in number, and exhibiting them in various plumage, Scotland

1400 Least horned owl, m. and fem. Strix variegata, very rare

1401 Red-headed woodpecker, North America

1402 Pintailed duck, anas acuta

1403 Flight falcon, m.and fem. (hooded) Falco peregrinus

1404 Red-headed-smew, Mergus minutus

1405 Siskin, Gibraltar ; and jack-snipe 
1406 Crowned African crane, Ardea Pavonina, one specimen, without case

1407 Cuckow, S. America

1408 Guilemot, female; and rook hen

1409 Wheatear, young; and butcher bird, ditto

1410 Painted finch, emberiza ciris, America; and sparrow of Paradise

1411 Pelican, Jamaica, Pelecanus occidentalis

1412 Silver-breasted grebe

1413 Thrush, Christian's Island

1414 Small water-hen, S. America

1415 Gardenian Heron, Ardea gardenia

1416 Yellow wagtail, m. and fem, a marten, and a brown geatsucker

1417 Brown thrush, China, rare

1418 Beautiful pale yellow variety of Picus viridis

1419 Cock of the wood, and hen, Tetreo urogallus

1420 A very fine specimen of that extremely rare lird the three- toed ostrich, struthio tridactylus

1421 Blue carbonate of copper in minute crystals, and finely crystallized copper pyrites

1422 Large mass of yellow copper ore, with quartz; and blue and green copper ore combined with quartz crystals and tabular barytes $\%$

1423 Minute blue and green crystallizations of copper, on a gray vitreous copper ore, combined with iron ore, Pokadeschy, Siberia

1424 Red hæmatites or blood-stone iron ore, Lancashire; brilliant granular iron ore, in white quartz, Sweden; and foliaceous ditto, Lancashire

01425 Yellow quartz, on purple fuor, Durham; opake white quartz; and quartz, in large crystals, Cornwall

1426 Yellow copper ore interspersed through black mica, Sweden

1427 Group of yellow quartz crystals, Durham; white ditto, Cumberland; and a hollow flint lined with minute ditto, Dorsetshire

1428 Two specimens of malachite, Cornwall; and a blistered copper, from ditto

1429 Uncommonly fine specimen of grayish cubic fluor, with bevelled edges; deep violet cubic ditto, Derbyshire

-1430 A beautiful specimen of bright rose-coloured calcareous spar, crystallized in primitive rhombs, Hesse, rare $200-$

1431 Very large and fine group of violet coloured cubic fluor, with slightly bevelled edges, Durham 7

1432 A most elegant specimen of light bluish green calcareous deposition, (tinged by nickel); and red arseniate of cobalt, wirid pharmacolite, Hesse/2 
1433 Large specimen of yellow quartz crystals, or amethystine cubic fluor, having a natural fracture crossing its surface, Durham; and white quartz crystals, partially coated by calcareous spar

1434 A fine specimen of minutely crystallized manganese, on the surface of hæmatites, and a brown foliaceous iron ore

1435 Native copper, combined with vitreous copper quartz, \&c. from the mines of Count Pokadeschy, near Uralgeburge, Siberia

1436 A piece of the true avanturine being part of the great Leverian specimen; ancient artificial ditto, from ruins in Rome; and the modern imitation

1437 Thread-like chalcedony, crystallized in the hollow of a piece of quartz, Germany

1438 Oculus mundi, two speciniens $1-1-0$

1439 A very rich specimen of Lumachelli marble, unpolished, and exhibiting fragments of the shells, from whence the

o vivid colours of that species of marble are derived

1440 A large and fine specimen of crystallized cubic salt, from Nantwych, Cheshire

Fnd of the Twelfth Day's Sale. 


\section{THIRTEENTH DAY.}

Monday, the 18th of May, 1805.

S

1441 WYRINX, and a flute, Otaheite

1442 Lady's head dress, Friendly Islands; and a necklace

1443 Apron of a dancing girl, Otaheite

1444 Foul weather cloak, N. Zealand

1445 Elegant feather head dress, Brazil

1446 Curiously ornamented basket, Friendly Islands

1447 A very large piece of matting, New Amsterdam, S. Seas

1448 Curious basket, from ditto

1449 A very elegant gorget, Marquesas, S. Seas $f$

1450 Tusk of the Narwal whale, monodon monceros

1451 Trunk of tree, knawed down by beavers

1452 Snout of the sword-fish

1453 Remarḱably fine and large double horns of rhinosceros 22

145.4. Scull of the Greenland white bear, Ursus polaris

1455 Skin of boa constrictor, fifteen feet in length 10

1456 Shoulder-blade of whale $3-6$

1457 Tusk and jaw of sea cow, Trichecus rosmarus $/ 2$.

1458 Remarkably large jaw of a shark

1459 Horns and part of the skull of the African antelope 10

1460 Hoof, and part of the leg of Lapland rein-deer, and ditto of Swedish elk

1461 Two impressions of vegetables, in coal slate 4.6

1462 Part of a vegetable impression, in coal slate

1463 Six specimens of wood jaspar, four of them cut and polished

1464 Sparry deposition, on a mass of reeds, and fossil tubipore, and a mass of shells 
1405 Fossil wood, two specimens, one perforated by many insects

1466 Two vegetable impressions in coal slate, one piece exhibiting the patterns of two distinct plants i $1-1 /-6$

1467 Six fragments of petrified wood, various

1468 Two casts of ammonites, and three other petrifactions

1469 Six various masses of fossil shells

1470 Part of a vegetable impression, and-its counterpart

1471 Several of the ostrea gryphites, imbedded in lime-stone, and two other masses of fossil shells

1472 Three pieces of fossil-wood, polished, and two others

1473 Bone of a bird, in laminated lime-stone, Stonsfield; and three impressions of shells

1474 A portion of the stem of a plant of the reed kind, impressed, and imbedded in free stone

1475 Three pieces of fossil-wood, two of them polished

1476 Six impressions of shells, \&c. $=1=0$

1477 Coal slate, with impressions of verticellated plants and another

1478 Fossil pecten, in laminated lime-stone, anomia ditto, and two impressions in iron stone 1

1479 Mass of marine bodies, fossillised, impression of a reed, and another

1480 A very clear impression of vegetable bark, in coal slate, and another, from Haigh in Lancashire

1481 Speckled antilope, Cape of Good Hope, (without case)

1482 Caspian goat

1483 Large specimen of common hare, with an extremely small ditto, and black variety of ditto

1484 Calf of the little Indian cow

1485 White hare, lepus alpinus $2=6$

1486 A fine specimen of the young zebra $f-a-\infty$

1487 A singular species of cavy, N. America

1488 Simia fatuellus, rare $10=$

1489 Lesser baboon

1490 Simia paniscus, long-tailed four fingered monkey, very rare 11

1491 Psittacus ararauna 2

1492 Aberdavine and Chinese sparrow

1493 Red godwit, and barn owl /

1494 Soland. goose, m. and fem. Anas Bassanus / 4

1496 Lemion-fronted parroquet, E. Indies

1497 Young woodcocks, with nest and egg, taken at Marston the seat of the Earl of Corke, near Froome

1498 Least grebe, male; common wren, and ditto robins, thee 2 cases 4,6 
1499 Bonana bird, and wax-bill, E. Indies

1500 Chinese sparrow, finch, ditto, red-pole, and white wren, m. and fem.

1501 Dottrell, and gold-finch, m. and fem.

1502 Large brown eagle $2-12 \ldots$

1503 Bustard, Barbary

1504 A fine specimen of the jer falcon, preserved in the attitude of attacking a heron, on which he is placed $/-1-1$

1505 Purple water-hen, S. America, Fulica porphyrio

1506 Crested Turkey $10 \ldots$

1507 Little falcon, Falco sparverius, m. and fem. $f-1+$

1508 Robin, N. America. O

1509 Painted finch, Emberina ciris, America; and canary, variety

1510 Black and yellow manakin, and gold-finch, Surinam

1511 Robin, Cayenne; and blue-finch, Africa

1512 Creeper, S. America; and taylor bird, E. Indies

1513 Blue-finch, S. America

1514 Green and yellow parrot, Brazils

1515 Lesser horned owl

1516 Least brown grebe, and a young cuckoo

$151 \%$ Puffin, m. and fem. North Pole

1518 Blue robin, N. America

1519 A fine specimen of the female bustard, otis tarda

1520. A noble specimen of the male bustard, otis tarda Norfolk, its weight was $29 \mathrm{fb}$

1521 Two large occidental argus porcellanæ, Providence; and a young devil's claw

1522 Two yellow-mouth seal's paws, (Bucc. fmlriatum, vur. Soland.) S. Seas; two scarce Lunati (Helix cornu Arietis, Linn.) and a rare scollop

1523 A devil murex of extraordinary, size, Madagascar; a spotted tun, Clina; and a granulated helmet, $W$. Indies $1 / 1$

1524. The black hammer margaritifera, Luconia, rare

1525 A trumpet of a rare kind, (Bucc. Doridis, Soland.) E. Indies; mactra gigas, Linn. from Florida; and two odd valves of rare double shells

1526 A chesnut land snail, a young parther porçellain, four olivæ, two bullæ, and an alatus

1527 Sections of the Arabian spindle, the bishop's mitre, and three needles, to exhibit their internal structure

1528 Cochlus singularis, in a young stage of growth, New South Wales ; a group of serpula filigrana, a scarce sun, South Seas; and a large ncrita of a rare kind, Isle of Cocoas

1529 A fine spondylus armatus, formed on another hinged oyster of the same kind, with adhesions of serpulæ, corals, \& . Martinique // 
1530 The studded helmet, Sicily; a young bull's-mouth helmet, and a scarce variety of the zebra trochus 10

1531 A large and fine iris ear, New Zealand.

1532 Conus pulicarius, Soland. Otaheite; the flambeaux cone, Amboyna; and a rare spotted tun, New S. Wales

1533 A royal mantle scollop, a cinnabar scollop, and a polished Barbary mussel 13

1534 A group of the coiled brown chequered worm, mixed with some white triangular serpulæ, and lithophagi, from Gui$n e a$; and a group of oriental tulip balani

1535 A variety of the spotted melon, Tranquebar; and a ramose triplex, Madagascar

1536 A nautilus pompilius, opened, to shew the cells and siphunculus; a young devil's claw, a spider strombus, and $i$ an American fig -

1537 The great brown European tun, Merliterranean

1538 A large tiger chersina, having the epidermis, and remarkable for its thickness, Guinea, rare

1539 A large emerald sea-snail, New Zealand; the pomegranate cochlus, anda scarce triplex 9 -

1540 Conus glaucus, Linn. very rare, from China; the South Sea argus frog, also rare, and a fine spectre cone $1=0-0$

1541 Three specimens of tungsten, Cornwall, rare $10=$

1542 White sparry incrustation, on moss, \&c. Cumberland; and coarse brown stalagmitical spar, with a cauliflowerlike surface, Matlock, Bath

1543 Black glossy polyhedral blend, on white quartz crystals, Cumberland; and blend with decomposed galena, and pyrites $0 . / \mathrm{f} \cdot \mathrm{c}$

$1544 \mathrm{~A}$ hollow specimen of stalactitical galena, the surface of which is formed into small exoctohædral crystals, coated with ochraceous iron ore, Somersetshire, very rare

1545 A large mass of galena, combined with barytes, Cumberland; and a galena, with pearl spar

1546 Delicate violet cubic fluors, on calcareous spar; light violet ditto, violet ditto, sprinkled with quartz crystals; amethystine ditto, in fine cubes, Durham; grayish ditto, with bevelled edges, and another, Derbyshire

1547 Fine specimen of crystallised apatite, Saxony
1548 Yellow quartz crystals, Bristol; quartz surrounded by agate, Oberstein; congeries of brown quartz crystals, assuming a stalactitic form, Bristol; mountain crystal, Switzerland; and smoak crystal, Bohemia

1549 Four varieties of mountain crystal

1550 A large and fine group of purplish cubic fluor, nearly covered with large and very small brilliant quartz crystals, Durham 
1551 A curious impression of a zoophyte in flint, and a mass of various fragments of ditto, in lime-stone

1552 A handsome specimen of crystallised galena, or purple fluor, Cumberland

1553 A fine specimen of slickensides galena, Derbyshire

1554 Galena, in cubes, much intersecting each other, with minute cubic fluor in the interstices, Derbyshire; and cubic galena, on gray fluor, ditto

1.555 A fossil sponge, and impression of fern, on iron stone

1556 Aurum graphicum; Felsobania; iridescent antimony, ditto; native silver, Saxony ; and groy silver ditto 4

D 1557 An antique sacrificial cup, formed of very fine flesh-colored agate $1-12-b$

1558 An elegant and brilliant specimen of the noble opal

1559 Native muriate of silver, Siberia, extremely rare

1560 Large and capital nodule of sapharine chalcedony, having a cavernous central cavity, which is lined and partly occupied by opake pink, and light yellow chalcedony of an hydrophanous, or water-absorbing quality. This specimen which is of singular beauty and perfection, is said to have been found in France

End of the Thirteenth Day's Sale. 


\title{
FOURTEENTH DAY.
}

\author{
Tuesday, the 19th of May, 1806.
}

$1561 \AA$ Ball of very fine plaited cordage, made of the fibres of the cocoa nut, Sandwich Islands

1562 Cloth beater, Otaheite, and a basaltine adze, frorn ditto

1563 Leg bracelet, made of shells, Sandwich Islands; and a polished bowl, (for playing with) from ditto

1564 False hair, worn on the neck by way of ornament, ditto'; and smail salt dish from ditto

1565 Instrument set with shark's teeth, and a gorget, from ditto

1566 Dagger, termed a pahoo, and feather ornament for the head, from ditto

1567 Comb, King George's Sound; and fishing implement, from ditto

1568 Very strong and curious fishing line, made of human hair, from ditto

1569 Hood, made of very fine squirrel skin, Cook's River

1570 Gloves ornamented with porcupine quills, Prince William's Sound

1571 Scoop, made of a horny substance, from ditto

1572 Truncheon made of bone, from ditto

1573 Rattle, shaped like a bird, from ditto

1574 Elegant imitation of engraving, executed in composition

$1575 \mathrm{~A}$ framed and glazed drawing of the Dodo

$1576 \mathrm{~A}$ curious drawing by Miss Joddrel, in which the name of "Ashton Lever, Esq." is represented by figures in various attitudes 
1577 A very handsome fly-flap made of the Persian cow's tail, with an elegant silvered handle

1578 Remarkably beautiful representation of a landscape and birds, executed in straw, by Miss Gregge, framed and glazed

1579 The gold brocade cone (conus textile, Linn.) of extraordinary size; the pyramid trochus, uncoated; and a large black tiger cone, fine

1580 Cochlus singularis, in a young stage of growth, New South Wales; a group of serpula tiligrana, a sćarce sun, South Seas; and a large nerita of a rare kind, Isle of Cocoas

1581 A pyramid trochus, New Caledonia; the black tiger cone, (conus marmoreus, Linn.) and a small bull's-mouth helmet

1582 The flag cone, the studded scoop, and the large spectre cone

1583 The woodcock triplex, the pig's snout buccinum, and a scarce oriental buccinum

1584 Two scarce brindled senecti, W. Indies, another scarce senectus, ${ }^{\circ} S$. Seas; two antique purpuræ; a black club, N. S. Wales; and three others

1585 The orange-mouth ear-like terrestial shell, New Caledonia, very rare

1586 A finely-coloured papal crown, Amboyna; a bishop's mitre, China; and a coronated needle, Tranquelar

1587 A large and fine rhombus draco, or dragon rhombus, Tranqueliar, very rare

1588 The black mother of pearl shell, Otaheite, uncoated and polished

1589 Two fine dolphin snails, and an extremely rare chersina

1590 A pin-cushion helmet, two porcupines, two footmen buccina, a bronze trochus, and three others

1591 Conus grandis, Guinea, rare ; and a fine bull's-mouth belmet//

1592 Two pheasant snakes, a Holland flag, mulbery trochus, and two others $/ 2-6$

1593 Bulla rubra, Guinea; another large bulla, N'ew S. Wales.; a chesnut land-snail, an emerald cochlus, four olives, and a conus fulgens

1594 Senectus singularis, with its remarkalle operculum, South Seas, very rare ; conus pulicarius, with the epidermis on ? Otaheite; and a singular variety of conus proteus $10-6$

1595 The ham pinna, with its byssus, Sicily

1596 Two orange-mouth olives, two gibbous olives, a black African music, and a bat volute

1597 The coronated needle, the Trajan s column needle, and a young Arabian spindle

1598 Couns nussatella, Amboyna; conus lucanicus, Ceylon; and the brown coquette scoop, $S$. Seas-all rare 


\section{MONKEYS GROTESQUELY SET UP.}

1599 The tumbling monkey

1600 The Family Carpenter, / /

1601 The Gamesters

1602 The Family Watchman,

1603 The Student, thes

1604 The Lamplighter,

1605 Tooth-drawer,

1606 Oriental jasper; granite, Scotland; amethystine quartz, coated with calcedony; and flesh-coloured calcedony coating quartz

1607 A fine specimen of adularia, in basalt, Hesse

1608 Yellow fluor, on cauk, with galena, Derbyshire; and plated barytes, Derbyshire

1609 Hyacinths, with mica, Vesuvius 16

$001610 \mathrm{~A}$ beautiful Brazilian crystal of a rich yellowish colour, exhibiting amongst other internal appearances the resemblance of an expanded blossom of the wild-rose, and another specimen of ditto, with green moss-like figures within

0 1611 A fine specimen of breciated agate, very curious, Saxony

1612 Black shorl, Spain; chrysoprase, Silesia; black shorl, Saxony ; and another $\rightarrow$

1613 Oriental jaspar, a large and fine specimen

1614 Grey cubic fluors, Derbyshire -

1615 Semi-orbicular marcasites, a nodule of brilliant marcasites, rose ditto, cockscomb pyrites, and two others $/ 5^{2}$ in

1616 An elegant and well-defined impression of a fish, in indurated marl, probably from Mount Carmel

1617 Very brilliant marcasites with calcareous spar, a large and fine specimen $/=12$ ?

1618 A handsome specimen of hyalite, or Müller s glas s, Frankfort

1619 Papilio epius, phal. villica, and nineteen others, chiefiy. phalæna

1620 Phalæna bubo, and three other moths 4

1621 Papilio Paris, and four. insects of the noctua family $2: 6-$ -

1622 Twenty lepidopterous insects, among which are phal. tạu, bucephala, and papilio levana

1623 Phalæna atlas, a large specimen, China 80

1624 Phalæna luna, North America, and two large bombyces $/ 8$ :

1625 Ditto

1626 Phalæna luna, and two other phalænæ, North America of

1627 Three bombyces, among which are phalæna luna

1628 Vitreous tin in Elvan stone, from Penzance, Cornwall; and another tin, crystallized 
1629 A curious specimen of wood, exhibiting it in an early stage of transformation into coal, Hesse

1630 A ditto, strikingly shewing the structure of wood still further advanced towards coal, from ditto

1631 A large specimen of pitch coal, Hesse

1632 Brown hæmatites interspersed through the cavities of a toadstone, from ditto

1633 Tin, in steatites, Cornwall, and two other tins

1634 Violet cubic fluor, in small crystals; and a pale purple fluor, richly coated with pearl spar

1635 Clouded red and yellow jaspar, Sicily

1636 An interesting specimen of zeolite upon an ore of arsenic, Hartz

1637 Brilliant dark smoke-coloured crystals of quartz; agate, being part of a nodule, Oberstein; rugose quartz crystals, with a dark coating, and white quartz

1638 Stalactitical red hæmatites, with double-pointed quartz crystals, Bristol; red quartz crystals, from ditto, and a singularly formed hæmatites

1639 Double-pointed crystals of quartz, a large group, from Mount Caucasus

1640 A curious zeolite, Ferroe, and cyanite upon micaceous shistus

1641 Stream tin, Cornwall; and various crystals of tin, ditto

1642 Five various specimens of vegetables, and fossil-wood 2

1043 Seven various clear impressions of fossil plants, chiefly of the reed kind //

1644 Nine different kinds of vegetable barks, \&c.

1645. Seven different specimens of fossil impressions, in laminated lime-stone

1646 Six impressions of plants of the reed kind in coal slate, and argillaceous iron ore

1647 Fourteen various fragments of fish palates, serpula, \&c.

1648 Beautiful bubbled marcasites, ditto, in a stalactitical form, and flior, coated with marcasites

1649 Green phosphate of lead, Saxony; and thread-veined lead ore, Derbyshire

1650 Crystallised sulphate of strontian, two varieties, Bristol; pearl spar, on fluor, and polished slab of cauk, Derbyshire

1651 Native amalgam, on white argil. Deuxponts

1652 Laminated granite, from Peterwalde, Bohemia, rare

1653 Ruddy-red, and purple variety of iridescent labrador, and another specimen of a singularly deep purple and blue ditto

1654 Crystallized lepidolite, in white quartz, Moravia

1655 A small agate cup and cover, (very handsome) Germany

1656 Wolfram, Cornwall; crystallised blend, crystallised antimony, and mispickel

1657 Molybdate of lead, in fine crystals, Carinthia; and solid vitreous copper, with malachite, and native copper, Siberia/ 
1658 A lily encrinus, with the stem very fine and perfect, Brunswick of

1659 Brass ore (of Raspe); calamine, Flintshire; crystallised blend, and blend with pyrites $y$

1660 Polished specimen of chain coralloid, cast of another, Mrestricht; various casts of curious minute sulcated bivalve shells, imbedded in lapis Suillus, Sweden

1661 Six specimens-three antimony, one molybdena, Anerica ; manganese, Illefeld, and native quick-silver, Dupont

1662 Four specirnens of cornish tungsten, Cornwall, rare/1

1663 Six specimens of crystallised tin, Cornwall 12

1664 Iridescent plumose antimony, two garnets, said to contain gold, and rose-coloured manganese

3665 Crystallised manganese, Illefeld; stellated arseniate of cobalt, Saxony; and native vermillon, Dupont

1666 Calamine, curiously crystallised, in transparent plates, on ferruginous quartz, Siberia, very rare

1667 Cross-stone, Andreasberg; zeolites, quartz, in crystals of a white colour, having their summits jet black, Derby; and another quartz

1668 Six specimens of tin crystallised

1669 Smaragdite

1670 Plumose gypsum, an uncommonly fine specimen, from Matlock, Derbyshire o o

- 1671 An elegant group of white quartz crystals, partially coated

with botryoidal calcareous spar, and pearl spar, Hungary

1672 Rich galena, in well-defined fourteen-sided crystals, on a group of white cubic fluor, sprinkled with marcasite, \&c. Derbyshire; pearl spar, with galena, marcasite, and quartz, \&c. Cumberland

1673 Brown spathose lead ore, with red and yellow ochre, Altay in Siberia

1674. Large and handsome cubric galena, partially coated by pearl spar, on quartz

1675 A curious box, formed of agate, Germany

1676 Black shorl, imbedded in quartz and mica, one crystal complete, having the tetrahedral summit, Spain, rare

1677 Snow-like native silver, upon yellow iron ore containing silver, from Nertschinsky, Siberia; and a small specimen of native silver, in quartz, Hungary

1678 A very fine specimen of crystallised sappharine blue salt; Hungary, extremely rare

1679. Native silver on phosphorescent blend

1680 Siberian tourmaline, in gneiss

\section{End of the Fourteenth Day's Sale.}




\section{FIFTEENTH DAY.}

Wednesday 20th May, 1806.

1681 RNAMENTED feather hammock, Brazils 2.

1682 Elegant model of a bark boat, Canada

1683 Richly ornamented hooker, E. Indies 4

1684 Similitude of Pondiac the Indian Chief, cut in stone with his own hands

1685 Carved cocoa-nut cup set with silver at a

1686 Complete model of a Chinese pleasure barge

1687 Chinese compass

1688 Large specimen of matting, N. Amsterdam

1689 Very large meat dish, Otaheite

1690 Lepidolite, Moravia; sulphate of strontian, Bristol ; ditto in larger crystals tinged with blue; acicular baroselenite, dark mica, and another-six specimens

169 I Six specimens of marcasite, including a piece of limestone, with fourteen-sided crystals, Sheepy Island

1692 A delicate specimen of azure blue oxyde of copper, with variegations of red and green; ditto, in a white argilla: ceous matrix, Siberia, very rare

1693 Large amethystine cubic fluor, with white crystallized quartz, and galena on the surface, Durham 2-6.

1694 Brilliant green mamillated iron, Germany, a highly elegant specimen $/ 1$

1695 Fifteen various crystals of tin, Cornwall $/-6$

1696 Rose-coloured manganese, Transylvania; vitriolated lead, Anglesea : silver mica in quartz; cauk, two specimens ; and sulphate of strontian, Bristol

1697 Dendritical native copper, in white gritty clay, from Woselkrantzkyshen Geburge, in Siberia-extremely rare 
1698 A group of greenish fluors, with bevelled edges, many of them frosted with spar, Derbyshire 5 - $b$

1699 Crystallized solid malachite in quartz, a fine specimen, and very rare $1-1 /-6$

1700 A large and fine group of well-formed deep, amethystine fluor, Durham $q-1-0$

1701 Amianthus, with cupper; arseniate of copper, and iron; and four others

1702 Eight various crystals of tin, Cornwall / 6

1703 Tin, in large crystals, and three others, Cornwall

1704 Small tessellated, or dice-like marcasites, sprinkled on the surface of dark cubic fluor, Derbyshire

1705 Calamine, with delicate white crystals of sulphate of lead, Hesse

1706 A large and handsome specimen of crystallized native gold, Hungary

1707 Black crystallized mica, disposed in strata upon an opake white quartz

1708 Smoky rock-crystal, a fine group, Switzerland 10

1709 Seven varieties of mountain crystal; a smoky quartz, and a yellow ditto with fluor, Durham

1710 A curious Egyptian pebble, bearing a striking resem: blance to a grotesque human head-in a frame

1711 Red fortification-like agate, Oberstein; and another, Germany; with two specimens of oriental agate, all cut and polished

1712 Dark blende, having the surface, beautifully sprinkled with brilliant white quartz, in minute crystals; copper, with quartz crystals, Cornwall ; and quartz, Bristol $/ 3$

1713 Lichen geographicus, a large specimen, on a rock stone, from Westmoreland

61714 A snuff box, formed of Jaspachates, from Oberstein

Oo 1715 Oberstein agate, cut and polished, the clouded part of which is sather distinctly marked with the figure of a Madona, red carnelian, and chalcedony, from the Leverian specimen

1716 Four elegant varieties of polished agate

1717 Spanish avanturine, and the antique imitation of avanturine, from the ruins of ancient Rome

1718 Ferruginots quartz, Bristol; chalcedony, a pudding stone, and two specimens of jaspar

1719 Pitch stone, veiry rare, Siberia ; a rhombidal crystal of feldspar, granite Scolland, and fortification agate

1720 Six specimens of minerals, including black shorl, and a green copper, with topazine crystals

1721 Lapis lazuli, a fine polished slab, amethystine quartz, ditta, and four other polished specimens

$0 \quad 1722$ Six specimens of minerals, among which are three Oberstein agates, green jaspar, and two others 
1723 A very fine and clear crystal, from the Glacieres, Switzerland

1724 A fine piece of labrador horn-blend, having green and blue iridescent labrador attached to it, rare; and a polished specimen of light-coloured labrador feldspar

1725 A specimen of green mica, with quartz; a slab of polished cauk, Celestine, Bristol; sulphate of strontian, ditto; and another-in all six specimens

1726 A very large mass of incrustation, from Matlock, Bath

1727 Amethystine fluor, in large cubes, Durham $/-1$

1728 Specimen of beautiful green strontian, Scotland; sulphate of stiontian, in large crystals, Bristol; and barytes

1729. Pale äthothystine fluor, in small crystals, Durham

1730 Two manufactured specimens of Mr. Cort's patent iron, rondered 14 ble from cast iron 7

1731 Noble speem en indented quartz, the cavities of which were frum 1 t 3

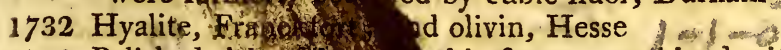

1733 Polished slab wh o ubic fluors, combined with fleshcoloured carte 1 .

1734 A very elegant fo f crystallized native gold, on quartz, \&c. Huntshy

1735 Tellurium, on $/ 1$ the sy sylvania; and bubbled white calamine, Hessers

1736 A large and fine speoduet rana bicolor
173 - Squilla adactyla, sereral kes, and another, in three bottles

1738 A large and fine species of $s$

1739 Sparus auratus, the lunated $\mathrm{g} t$-head

1740 Two beautiful banded snakes, and another-in all three bottless

1741 A curiously contorted lusus of the carrot

1742 A fine specimen of lacerta caudiverbera

1743 Clupea pilcardus, the pilchard in spirits 4

1744 Rana paradoxa, a fine specimen

1745 Anatomical preparation of a fróg, shewing the internal structure

1746 Turnip-tailed lizard, a very fine specimen

1747 A fine specimen of the young crocodile in the egg, the shell being partially broken $/-0$

1748 A gigantic specimen of scolopendra morsitans, and a large scorpion, from Africa

1749 A very good specimen of lacerta crocodylus, and a bull frog, Rana Catesbeiana, (without case)

1750 Bastard plover, and capuchin pigeon, two cases

1751 Dottrel, $\mathrm{m}$. and fem. and ring turtle dove, $\mathrm{m}$. and fem, 
1752 Wood owl, water hen, and common crow 1

1753 Red-throated grebe, fem. Colymbus rufficollis, very rare

1754 Ash-coloured crane, N. America

1755 Gambo goose, Cape of Good Hope

1756 Elegant fawn-coloured variety of common thrush $/-150$

1757 Mino grakle, Gracuta religiosa

1758 White-bellied linnet, and bramble finch, $m$. and fem.-two cases

1759 Yellow cubic fluor, with blend; galena, with blend; and tetrahedral blend, intermixed with cubic fluor, and double-pointed spar

1760 Heliotrop, and a large and singular yellow carnelian

1761 Zeolite, shorlite, amethystine quartz, and amethysts, in agate 40

1762 Iridescent quartz, cut into form of a cane-head, another of crystal, and a fine carnelian

1763 Two elegant specimens of iridescent labrador feldspar, one of which is remarkable for its singular dun-coloured variegations $y=6$

1764 Calcareous spar curiously intersecting an argillaceous matrix. Derbyshire; hyalite, Franckfort; a fine specimen of solid gray cobalt, Hesse; Framekenberg copper ore ; and

black shorl, in feldspar, Spain

1765 A beautiful specimen of white-wood jasper, Hesse $/ 3$

1766 Three modifications of marcasite crystals ; cockscomb marcasites; two casts of bivalve shells, sprinkled with marcasites; and others, in all eight large and six small specimens,

1767 Crystallized yray cobalt, Hesse; native vermillion, in an argillaceous matrix, Idria ; compact horn-blende, very rare, Germany; compact shorl, ditto

1768 Green oxyd of nickel, Hesse; and brilliant crystallized gray cobalt, ditto

1769 Cubic ruck salt, Barcelona, rock salt, cut into the form of a pear, and rock crystal, Wales

1770 Two Trajan's column needles, and a bishop's mitre, $M a$. dagascar, all fine

1771 Twenty curious teriestial, fresh water, and marine shells of different genera

1772 A very large Arca rhomlied Born, S. Seas; and two fine leopard porcellanie

1773 Two black-mouth Jani-snails, Portugal; a sharp-edged lucerna, $W$. Indies; two lineated rhombs, New Zealand; a French horn, and and three olives

1774 Two rare brindled many-whirl'd screws; a scarce distaff, two bishop's mitres, and two others 10

1775 Two white caterpillar clubs, three mitres, two of conus nussatella, the siender English rhombus, and two others. 
1776 A black club, New South Wales; the abbot's mitre $M a$ dagascur; two of conus tulipa, and two others

1777 A small papal mitre, a bishop's mitre, a scarce white tower, from Martinique; and two rare needles

1778 The many-lipped bombyx, an African tower, the punctured amygdalum, and banded dactylus, two alatæ, a-trochiform chersina, and two other rare shells 13

1779 The occulated and ferruginous needle, two others of the same genus, and a spotted crane, all from China

1780 Two dotted myosotæ, three mitres, two of helix zonariz, Pennant; the lineated mitre of China; two corrugated cochleæ, Madeira; two ruffled mulls, and three more $/ 0$

1781 A large and fine cock's-wing clam, Ceylon; a poached egg shuttle, and a beautiful undulated variety of the leopard porcellana, Otaheite

1782 Four various olives, the French horn, and four other land shells, two red bullæx, and the purple oceanic snail

1783 Four curious mitres, viz. the abbots, from Madagascar; the Hottentot, China; the clouded, S. Seas; and one other

1784 Bulla zonatus, Tránquebar; bulla lignaria, the pigeon egg dipper, two black-mouth land snails, and ten others

1785. Two of helix variegata, China; the ribband land snail, Granada; two scarce pyra, Tranquebar; and four others

1786 Two of helix variegata, Clina; three bullæ, a small richly coloured guinea music, and three others

1787 A reverse knobbed fig, from Florida; the chequered fig, China; and the splendid clam, Ceylon-rare

1788 A large and fine Tower of Babel, the occulated and coronated needles, and two small bishop's mitres

1789 Pectunculus cribrum, on seiye clam, China; and cardium spinosum, Sicily

1790 A fine cardium costatum, Linn. or hollow-ridged cockle, from Guinea-rare

1791 A most elegant and choice specimen of remarkably welldefined cubic fluor, having the crystals coated by a delicate olive-green argillaceous powder $3-4-b$

1792 Fortification cobalt, Hesse; gray cobait, ditto curious dendritical copper nickel, ditto; crystallised realgar, Hungary; ore of mercury, Idria; silvery calcareous earth, Hesse

1793 Garnets in micaceous shistus, Scotland; leucite, Vesuvius, and actinolite

1794 A very large crystal of Garnet, Bohemia

1795 Artificial cat's-eye avanturine, blue dendritical agate, and a mocha

1796 A fine specimen of Franckenberg copper ore, with vege.

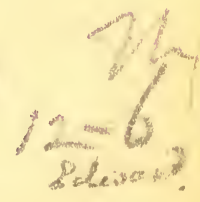
table remains 
1997 Olivin, in basalt, Hesse; porcellain jaspar, ditto ; bright red garnets, in the matrix, and three agates, cut and polished

1898 A very elegant specimen of purplish fortification cobalt, Hesse ; a choice specimen of needle antimony, Hungary; and two others

1999 A remarkably pellucid Brasilian crystal, replete with spicular appearances, and another, with singularly beautiful iridescent colours 1900 A fine group of Brasilian rock crystal, deeply tinged near green 1800

End of the Fifteenth Day's Sale. 


\section{SIXTEENTH DAY.}

Thursday, the 21st of May, 1806.

$1801 \mathbb{F}_{\text {ISHING instrument, and a fish-skin file, Otaheite }}$

1802 Comb, tattooing instrument, and a sling, from ditto $4-6$

1803 Curious idol, from ditto $4-6$

1804 Dancing girl's apron, from ditto 3

1805 Elegant head ornament, formed of red vegetable beads, from ditto /

1806 Singular ancient French belt, with cartridge cases

1807 Elegantly ornamented basket, Friendly Islands

1808 Chinese mandarin's cap 4 .

1809 Lady's winter gloves, Hudson's Bay (in glass case)

1810 A very handsome Turkey jasmine-tube pipe, ornamented with lapis lazuli and amber 16

1811 Highly ornamented Persian slippers

1812 Large sleeping stool, Otaheite

1813 Large meat dish, ditto

1814 Filegant ornarnented basket, Friendly Islands

1815 Very large adze head, formed of green nephritic stone, New Zealand $4-4-0$

1816 Curious variegated straw box, Canada

1917 Gentoo bible 15

1 18 Large ivory bracelet of an African princess //

1819 Perfect and handsome fur dress, Hudson's Bay $1 / 3-6$

1820 Beautiful cap, formed of the feathers of rare and beautiful birds, Brazils $1-1 /-10$

1821 Five curious fossils, chiefly impressions of shells /

1822 Part of a spiny pecten, and the valve of another pecten, an anomia, \&c. in chalk, four specimens 
1823 Impression of a shell, in stone; two dittc, in laminated lime-stone, and auother

1824 Mass of turbinated shells, France; impressions of shells in laminated limestone, \&c. six specimens

1825 Seven impressions of pectens, ostraæ; turbinated shells, \&c.

1826 Two polished? specimens of encrinus marble, groups of fossil shells, \&c. six specimens

1827 Part of an asterias, in chalk; and two echini $1-6-0$

182.3 Land rail, $m$. and fem.

1829 Pompadour fronted parroquet, S. Seas 16

18,30 Common jay, and ditto pigeon 19.6

1831 Ruff, male, tringa pugnax; and powter pigeon //

1832 Gold pheasant, m. and fem. China 2- 3 .

1833 Crested grebe, $\mathrm{m}$. and fem. Colymbus cristatus

1834 Female golden-eye duck, and garganey, fem.

1835 Heron, male $\ldots$

1836 Little auk $/-1-\infty$

1837 Black guillemot, and gold-winged woodpecker, two cases $\$-1+c$

1838 Black-throated barb; and the nun pigeon, two cases 8

1839. Black tern, sterna.nigra, m. and fem. /

1840 Booby pelican

1841 Razor-bill, two specimens

1842 Crane, Ardea Grus, m. and fem.

1843 Red-winged duck, Jamaica

1844 Spanish duck, and jackdaw / - -

1845 Swallow, m. and fem. with their nest constructed in a strombus shell. The shell was accidentally left in a garden near Sir Ashton Lever's, at Alkrington, and the nest formed there and eggs laid by the fem. bird 4.0

1846 Small linnet, Africa; green wren, green woodpecker, and hybrid goldfinch, four cases $/ /$

1847 Buzzard hawk, m. and fem. -13 ,

1848 Bald duck, N. America, $m$. and fem.

1849 Avadavad, small brown water-hen, wheat-ear, male; and starling, four cases

1850 Pelican, Hudson's Bay o $4-0$

1851 Black grous, $m$. and fem. Tetrao tetrix $2-1 / 4, c$

1852 A most beautiful specinen of the pheasant turkey, Georgia

1853 Dendritical copper nickel, with green oxyd of ditto, purple calcareous deposition, tinged by cobalt, Hesse ; cinnabar, and hyalite, Franckfort

1854 Pale topazine fluor, with cubic galena, Durham

1855 Dark red cinnabar, Idria, and a fine specimen of fortification cobalt, Hesse

3856 Native silver, on quartz crystals, Potosi ; bismuth, and copper nickel, Germany; dark red cinnabar, Idria; red and brown spotted marble, Hesse $/ 3$. 
1857 Cobalt, with green oxyd of nickel, Hesse; crystallized brilliant gray cobalt, ditto; rose-like gypsum, ditto; and light red cinnabar, Idria $-\infty$

1858 Impression, in coal slate of a portion of the stem of a plant of the reed kind, and part of bark, in ditto

1859 Six elegant specimens of fossil wood, three of them polished

1860 A very large mass of lime-stone, with a variety of marine remains $10-6$

1861 Impressions of several vertebral joints, in lime-stone 2

1862 A large fragment of fossil-wood, perforated by marine animals

1863 Four fragments of the stems of vegetables, and fossil-wood

1864 Singular fossil body, supposed of yegetable orizin, and two impressions in coal slate

1865 Six shells, among which are a fossil patella, part of a mamillated echinus, reverse whelk, \&c,

1866 Calcareous fossil-wood, a slab, cut and polished, from the Isle of Portland $1-3-b$

1867 Impressions of vegetable bark, seven specimens 12

1868 Two pieces of fossil-wood, one from Wiltshire

1869 Three pieces of fossil-wood

18,0 The lapwing's egg bulla, China , the red bulla, Guinea; the chesnut, and another lamp snail, Jamaica; and two others

1871 Four needies, (the leopard, the panther, and two ferrugi, nous) two press screws, and a rare brindled screw

1872 The ferruginous and gray-ridged mitre, the wheat-sheaf cuma, a spotted needle, two dactyli, and four others

1873 The thorny gryphus (chama arcinella, Linn.) a small foliated purple spondylus, and a purple gryphus-the last attached to a madrepore

1874 The sulcated sun, New Zealand; two magpie apiculi, and a blunt-ridged triplex, $W$. Indies

1875 A fine clouded Persian crown melon, (voluta amphora, Soland.) Molucia Iles, rare 3

1876 Yellow variety of the variegated spondylus, Friendly Islands; and a small-rayed variety of the black margaritifera, with the lorder complete, Sandwich Islands

1877 The watering pot, from Sumatra, rare

$10-1-\infty$

1878 The wax taper cone, (conus virgo, Linn.) China, uncoated; and two of cuma polymita, Madagascar

1879 Two hercules clubs, one of them in a young state, and a fine bishop's mitre

1880 The great cockscomb oyster, Frièndly Islands

1881 A large and fine purple-ringed trochus, Nootka Sound; very rare 
1882 The pomegranate sea snail, having a remarkably indented edge to the mouth, from the Cape of Good Hope; a curious operculum of the same species, and a sulcated sun, New Zealund

1883 The furbelowed triplex, Nootkn Sound; a fine grimace buccinum, Madugascar; and a large herald cuma, South Seas

1884 A large partridge tun, S. Seas, rare

1885 Two purple-mouth alatæ, Florida; a vase murex, West Indies; two armed scoops, S. Seas; and an aculeated cassidula

1886 Several of the thorny balanus, on a tulip balanus, $E$. Indies; and two rare shells of the chiton genus

1887 A large and fine voluta vespertilio, or bat volute, Ceylon

1888 A fine reverse fig, (murex perversus, Linn.) from Florida, rare 13,2

1889 Two beautiful varieties of chersina perversa, from China, very rare, and a fine staircase

1890 Roebuck horns, in their velvet state, and common hedgehog, two cases

1891 Flying squirrel, and mouse variety 2

1892 Opossum rat, Surinam

1893 Squirrels, m. and fem. and lap-dog, two cases

1894 Fox, N. America

1895 Ichneumon, Egypt, viverra ichneumon

1896 Dog, Otaheite o

1897 Large specimen of the Otaheite Sow

1898 Tailless macauco, Lemur tardigradus

1899 Beaver, N. America

1900 Bat, Madagascar, vespertilio Vampyrus $f-13-0$.

1901 Long-tailed baboon

1902 Simia Beelzebul, rare (without case)

1 g03 White-eared monkey, St. Jago

1904 Dog-faced monkey $/$

1905 White-eyed baboon $f+14$

1906 Prase, Saxony; and porcellain jaspar, ditto / 2 sos

1907 Adularia, in basalt, Hesse

2 1908 An elegant oval box, formed of wood jaspar

1909 Native white oxyd of manganese, on coloured stalactitical hæmatites, Triers, very rare

1910 An elegant group of yellow spar, in sharp-pointed hexagonal pyramids, Derbyshire

1911 Curious sparry incrustation, formed within a square water pipe /

1912 Three elegant specimens of labrador feldspar 5 .

1913 Violet cubic fluor, in small crystals, on the surface of 2 group of white spars, Derbyshire 
1914 A fine specimen of cinnabar, with native vermillion, Idria; and compact gray cobalt, Hesse

1915 A large crystal of red quartz, and a group of opake quartz crystals

1916 Native copper pervading vitreous copper and quartz, Siberia, cut and polished

1917 Ocellated jaspar, fare, Hesse, and garnets in the matrix, Germany

1) 1918 A curiously figured Egyptian pebble, polished section of agate, nodule filled with amethystine quartz, and a very fine red veined fortification agate, Oberstein,

1919 A very capital specimen of dendritrical nickel, rare, Hesse 1920, True avanturine, a very fine slab, from the great Leverian specimen

Fnd of the Sixteenth Day's Sate. 


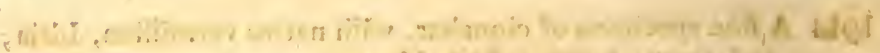

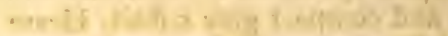

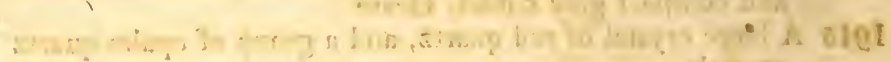
initis 10

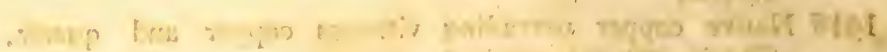

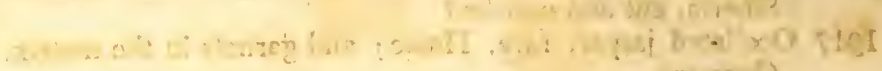
y(I) 1 )

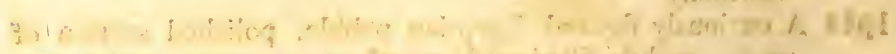

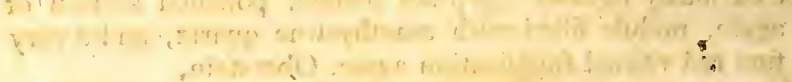

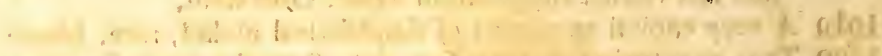

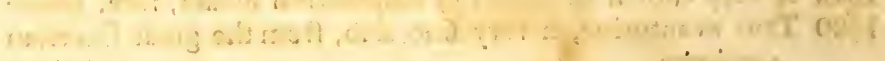
s. 


\section{Catalogue}

\section{OF THE \\ LEVERIAN MUSEUM, PART III.}

INCLUDING THE THIRD EICHT.DAYS SALE.

* * the recicaining parts will be published with all. POSSIBEE SPEED.

\section{THE SALE}

of

\section{THE ENTIRE COLLECTION}

(By Messrs. KING and LOCHEE,)

WILL COMMENCE.

On Moxpay, the 5th of MaY, 1806, at Twelve o'Clock,

- In the Building now occupied by

\section{․ THE MUSEUM.}

The fuur Parts of the Catalogub already published, (Price $3 s$. $6 d$.$) to be had at the Musrum; at Messrs. King and$ Lochée's, (the Auctioneers) and at Hayden's Printing-Office, Brydges-Street, Covent-Garden.

Mayden, Printer, 4, Brydges Street, Covent Carden. 


\section{CONDITIONS OF SALE.}

I. THE highest Bidder will be declared the Buyer; but if any Dispute should arise, the Lot must be put up again.

II. No Advance less than Sixpence; above One Pound, One Shilling; above Five Pounds, Five ShillLINGS.

III. Every Purchaser is to pay down Five Shillings in the Pound, as Earnest, in Part of Payment, and to give in his Name and Place of Abode, if required.

IV. The Lots to be removed, at the Expence of the Purchasers, within one Day after the Sale; and the Remainder of the Purchase-Money to be, paid on or before the Delivery.

V. Upon Failure of complying with the above Conditions, the Money deposited in Part of Payment shall be forfeited. All Lots uncleared within the Time aforesaid, shall be re-sold, by public or private Sale; and the Deficiency (if any) attending such Re-sale, shall be made good by the Defaulters a this Sale.

Gentlemen who cannot attend the Sale, may have their Commissions faithfully executed, by their humble Servants,

King and Lochée. 


\title{
SEVENTEENTH DAY.
}

\author{
Friday, the 23rd of May, 1806.
}

1921 COXIA Curvirostra; m. and fem. and cuckow, young 16

1922 Black and white smew, and young barn-owl 10

1923 Game-cocks trimmed and spurred, preserved in the attitude of fighting

m.

1925 A handsome specimen of the eider drake, Anas molissima

1926 Muscovy duck, fem. and scoter duck $/ 4$

1927 Large orange-crested cockatoo, Psittacus cristatus

1928 Starling, Gibraltar ; grossbeak, fem. and common pigeon 5 -6

1929 Falco furcatus, swallow-tailed falcon, extremely rare, $\mathrm{m}$. and fem. $2.20^{\circ} 0$

1930 Hawk, S. Seas, Falcovulturinus, very rare

1931 A beautiful specimen of the zebra curasso bird, Crax alector, var. C. $6 * 0-\infty$

1932 Puffin N. Pole $m$. and fem, and rouen duck, two cases $/$

1933 White variety of the turkey, $\mathrm{m}$. and fem. If

1934 Head of the: ardea pavonina, owl, and lesser pine bullfinch, Hudson's Bay-three cases $/ 1$

1935 Spotted eagle, N. America / - 2m-

1936. Golden pheasant, China, without case setele $1-1+0$

1937 Picus gilvo-cristatus, Surinam, rare

1938 Ardea lineata, very rare $/ 3$,

1939 Duck-winged game-cock, and stannel-hawk-two cases $/ 2-1 /$ 
1940 A noble specimen of the great penguin Pinguinaria Patch-

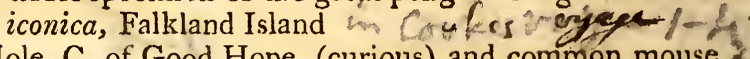

1941 Mole, C. of Good Hope, (curious) and common mouse

1942 Otter, female

1943 Young wild boar, Africa

1944 Fisher sable 3

1945 Young leopard, bred in the Tower of London

1946 Badger, male, Ursus Lotor $1=1 \cdot 0$

1947 Mustela erminia, and common weesel $8-6$

1948 Mungrel, between a Chinese dog and English spaniel

1949 Mosclus moschiferus, the musk-deer, rare $3+3=0$

1950 Raccoon, N. America

1951 Raphael's ware dish 1952 Antique bronze figure on horseback, Herculaneum

1953 A pair of bronze figures, from ditto met? $2-2-2$ kse
1954 Ancient English watch -6

1955 Two curious ancient knives, in an ornamentéd case

1956 Singular ancient wooden cup, with devices engraved on its surface $y=$

1957 Bronze figures of a woman and child, E. Indies

1958 A pair of grotesque figures, from ditto / 2

1959 Carved head, from the cave of Elephanta

1960 Very large and handsome Persian ware deep dish $-2-15$

1961. Curious flower-pot, formed of white marble

1962 Singular ornament of carved pink nephrtic stone, China

1963 Ancient English glazed ware jug, with metallic mounting

1964 Egyptian urn

+1965 Ancient embossed dish, and large red ditto

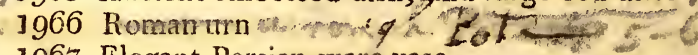

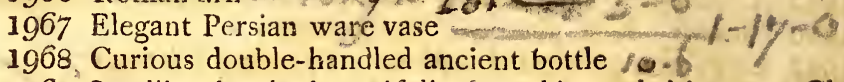

1969 Smelling-bottle, beautifully carved in nephritic stone, China \&

1970 Dish, formed of inlaid mother of pearl, \&c.

1971 Three impressions of shells, \&c. with their counterparts; and six others

1972 A parcel of small specimens of vegetable impressions, thirteen in number

1973 Five various impressions in coal slate, four of them of vegetable barks

1974 Two small fossil bones in laminated limestone, one with the counterpart and three parts of fossil palates of fish

1975 Twelve various fossils, shells, \&c.

1976 A large pecten in chaik 5

1977 A great variety of the fragments and joints of different species of encrini

1978 Two small bones of animals in laminated limestone, and eight various petrifactions

1979 Fourteen various impressions of shells 
1980 Six casts and masses of fossil shells, as pectens, \&c.

1981 Posterior half of the long-tailed anthropormorphita and its counterpart, in fuller's earth; a small bone of a bird, and an impression, Stonsfield

1982. Six various impressions of vegetable barks, in coal slate

1983 Five pieces of fossil wood, three polished

1984 Three fragments of echini, \&c. in chalk, two shells, and two other fossils

1985 Part of an asterias in chalk, ditto of a mamillated echinus, another ditto, and a smooth cordated species

1986 A belemnite in chalk, a pecten ditto, and part of a mamillated echinus

1987 A small bone cf a bird, a belemnite, various casts and impressions of shells - nine specimens

1988. An echinated pecten, an echinus, and a madrepore in chalk

1989 Bone of an animal imbedded in stone, and a large vertebral joint, Oxfordshfre

1990 Two trays of fossil remains, as serpnlæ, anomiæ \&c. chiefly shells

1991 A large and fine specimen of Milleporaalcicornis.

1992 A fine specimen of the variety of Madrepora muricata, W. Indies

1993 Very large specimen of Grainstone madrepore

1994 Purple variety of Corganie setosa

1995 Curious and rare star-stine, with a gorgonia flabellum, large purple ridged serpula, and other adhesions-W. Indies

1996 Antipathes spiralis $/-6$

1997 A remarkably fine and perfect specimen of May blossom coral, Madrcpora ramea

1998 The pied spondylus, China; the lion's paw oyster, Friendly Islands; and a scarce gryphus, Pulo Condore

1999 An alphabet, or lettered cone, Otaheite; a spotted trin, China; and a small bull's mouth helmet

2000 A large marbled snake, shell, China $*$

2001 A young bull's mouth helmet, a tuberculated scoop, a mosaic cone, an oak wood cone, a spotted pyrum, and a marble pavement helmet

2002 The hare alatus, Friendly Islands, rare; and two large olives

2003 The mole porcellain, China; the occidental argus porcellain, in a young state; aed a partridge tun

2004 A fine alatus latissimus, or broad-winged shell, (Strombus latissimus Linn,) very rare, Amboyna 12

2005 A small Ethiopian crown, Amboyna; a spotted turnep, Tranquebar; and a pink harp, from Guinea - all rare

2006 A very large Cardium spinosum, Soland. or thorny cockse, Sicily, rare 
2007. A fine aculeated pectunculus, (Venus dione Linn.) from. Jamaica, rare

2008 A large purple mussel, Straights of Magellan; (polished) and a flounder pecten, (ostrea pleuronectes Linn.) China

2009 The foliated triplex, Nootka Sornd; the saffron-mouth snipe triplex; and a singular aculeated purpura-all very rare the wantive ${ }^{2}+0$

2010 Two asperated bulbs, Tranqueterar; a scorpion strombus, China; a grimace bucccinum and two more

2011 A fine Ethiopian crown melon, Amboyna, rare

2012 A large and fine chersina tigrina, Guinea, rare

$20: 3$ The great spider, in a young state, S. Seas; a large Moor rhombus, Guinea; and a Persian robe cuma, China ty

2014 A black pinna, from China; and a fine pinna rudis, Linn. from Guinea-both rare

2015 The sulcated alatus, iw a young state, Gallapagos Isles, fine and very rare

2016 Conus bullatus, the occidental orange Admiral, and the scarlet mouth sun-all rare 3

2017 A large and fine cocoa-nut fresh water snail, Barbadoes, very scarce

2018 A large specimen coated with minute crystallized marcasites, and ferruginous calcareous spar

2019 Rock crystal, copper with quartz, several brilliant marcasites, \&c.-nine in number

2020 A large specimen of native arsenic, and a ditto of arseniate of cobalt, Saxony

2021 A specimen of prismatic feldspar, beautifully variegated with golden orange purple and blue

2022 A large specimen of crystallized calcareous spar, of a pale yellow colour, Derbyshire

2023 Bright green bubbled calamine, Wales; and solid galena, Derbyshre wit

2024 Golden coloured feldspar labrador, a splendid and extremely rare variety

2025 A specimen of lux sapphire, eyed agate, Scotland; and two more.

C 2026 Woodlike cornelian, reddish ditto, an onachine specimen of the Leverian chalcedony, and two others

2027 Very dark garnet coloured blend, in polyedral crystals, from Alston Moor, Cumberland

2028 Many-sided dog-tooth spar, on polyedral crystal, Derbyshire

2029 A hollow agate lined with amethysts, inclosing a singular calcareous crystal, from Oberstein in the Palatinate

2030 A rich sanguineous coloured jaspar, from the East Indies; a beautiful party-coloured fortification agate, and carious wood tike jebble 
2031 A curious specimen of gray crystallized calamine, Siberia, rare

2032 A large specimen of crystallized blend, Derbyshire

2033 Bright red cinnabar, in calcareous spar, \&c. Hungary; crystallized horn quicksilver, \&c. Idria; and a beautifully crystallized galena, Saxony

2034 A large slab of micacerts shistus, with small garnets, one side polished

2035 A pair of salts made of canal coal, with the crest of Sir $\Lambda$ shton Lever's arms engraved on theın

2036 A delicate specimen of feather antimony, Hungary; and bright green crystallized phosphate of lead, Saxony

2037 Plumbago in the matrix from Betsberg, Sweden; and hative quieksilver with horn quicksilver, Idria

2038 A beautiful and magnificent specimen of plumose gypsum, Matlock; Derbyshire

2039 A most beautiful and brilliant specimen of minutely crystallized gray cobalt, on the surface of a black argillaceous stone, Hesse

2040 A superb specimen of dendritical cobalt, from Hesse

End of the Seventeenth Day's Sale. 


\section{EIGHTEENTH DAY.}

Saturday 24th May, 1806.

2041 SAND Piper, m. and fem. and coddy moddy gull-two cases

2042 Black-headed tern, m. and fem.

2043 Gambo duck, m. and fem. E. Indies,

2044 Fox-coloured thrush, N. America

2045 Golden-eye drake, common jay, and ditto partridge

2046 Long-tailed dove, N. America

2047 Red-headed manakin, Cayenne, m. and fem.

2048 White Tern, N. America

2049 Cinnamon-coloured turtle dove, S. America

2050 Pink-shouldered thrush, $m$. and fem. N. America

2051 Scarlet-rumped parrot

2052 Summer duck, fem. N. America; and widgeon, maletwo cases

2053 A most beautiful specimen of the fiamingo, Phanecopterus ruber, with red and white variegations

2054 Brown wild goose

2055 Anas fuligula, tufted duck, m. and fem.

2056 Anas cygnoides, var. australis, m. and fem.

2057 Falco melanobronchos, white-headed hawk, S. America, very rare

2058 Cassuary, a fine specimen (without case)

2059 Falco angolensis, a very fine specimen and rare

2060 A capital specimen of Falco leucocephalus, very rare

2061 Lepus alpinus, Scotland 
2062 Spaniel lap-dog

2063 Viverra Leveriana, Leverian fossane, rare

2064 Marten cat, Mustela martis

2065 Ermine, m. and fem. mustela erminia

2066 Three specimens of young lions, bred in the Tower of London

2067 Porcupine, Siberia

2068 Maucauco, Lemur catta

2069 A handsome specimen of the buck

2070 Black seal, young

2071 Apron of a dancing girl, Otaheite

2072 Beautiful head ornament, formed of feathers, minute shark's teeth, mother of pearl, \& $x$ c. from the Marquesas, S. Seas

2073 Mandarine's boots, China; and Persian slippers

2074 Ornamented basket, Friendly Islands

2075 Stocking made of the silk of the large Mediterranean mussel

2076 Cork jacket, and Hungarian saddle

2077 Chiriese compass

2078 Cocoa nut cup, handsomely carved

2079 Chinese organ

2080 Ditto swan pan

2081 Ditto scales

2082 Ditto chopsticks

2083 Chinese ornamental figure, carved in pink nephritic stone

2084 Chinese ivory joss

2085 Ditto memorandum book, and instrument like a jews harp

2086 A slab of white marble, framed, with coloured figures of birds, and plants painted on its surface

2087 Chinese ivory ball, inclosing seven smaller, very curious and beautifully worked

2088 A rare purple cockscomb oyster, Acapulca; a saffioncoloured spondylus, W. Indies; and a spondylus rufus, E. Indies

2089 A scarce buccinum, with its epidermis, New S. Wales; and two large and fine tuberculated alatæ

2090 A fine Strombus dialolus, or devil's claw stromb. Madagascar

2091 Haustrum dentex, Gallapagos Isles, rare; a conus protheus, and a night admiral cone

2092 The great-branched triplex (murex ramosum, Linn.) of cxtraordinary size, Madagascar

2093 A large basket clam, China; a large tuberculated clam, Sicily; 'and a glycymeris

2094 A fine Arca senilis, Linn. or thick ark, from Guinen, very rare

2095 A fine voluta magnifica, or magnificent volute, New $S$. Wales, rare 
2096 Three curious and rare needles, viz. the oculated and 24 -1 coronated, from China; aud the tiger, from Guinea 2097 The violet-mouth, and two orange-mouth olives, two bishop's mitres, an oak wood cone, and two alatæ

2098 A slender distaff, with a distorted spine; a spotted distaff, with a curved beak; and a large and fine tower of Babel

2099 A fine tiger distaff shell, Cape of Good Hope, very rare

2100 A large and fine Pinna saccuta, Linn. or satchel pinna, Friendly Islands, very rare $/ /$

2101 The eared mya, from Brasil, uncoated ; and a trigonella violacea, Tranquebar, both rare

2102 The great brown European tun, Sicily

2103 A very large and fine partridge tun, S. Seas, rare

2104 The orange and brown variety of the swallow margaritifera, (Myt. hirundo, Linn.) China, extremely scarce

2105 The pigeon's egg lamp cockle, with the interior structure complete, and having curious adhesions of two kinds of scrpule, a millepora foraminosa, \&c. Minorca $1 / 13$

2106 A beautiful variegated cochlea, or land'snail, from Ceylon, very scarce 15

2107 The ruddy purpura, with beautifully coloured mouth, Guinea, very rare $1{ }^{\prime}$ t

2108 Nine various specimens of fossil vegetable remains

2109 Two small bones of animals, in laminated lime-stone, impressions of anomiæ, \&c. eight specimens.

2110 Lime-stone, with fragments of encrini, a slab of turbinated shells, polished, and another $\ldots \ldots+\infty$

2111 Seven different casts of shells

2112 Three impressions of vegetable barks

2113 Fragment of a singular twisted horn, supposed to be of an animal similar to the monodon monoceros $\mathscr{A}$ \& $/=0^{-}$

2114 A striated pecten, and another

2115 Three echini, cast of the inner part of another, and two casts of shells

2116 Nine various, including part of a fossil nautilus, Sheppy; echini, casts of shells, \&c.

2117 A pecten, anomia, and other shells, fossil tooth, \&c. in chalk

2118 Transverse section of an elephants tusk

2119 Fossil palate of a fish, in chalk, shells, belemnitæ, \&c. in chalk and flint

2120 A pecten, in chalk, east of a mytilus, \&c. in chalk

2121 Reversed whelk, Hordwell Cliffs, cast of a pecten, in flint, an echinus, \&c.-six specimens

2122 Anomia, in flint, pecten, belemnites in chalk, two fragments of madrepores, in chalk ; shells, Hordwell Cliffs, \&c

2123 Several species of echini, \&c, nine specimens

2124 Part of a fossil nautilus, stem of encrinus, casts of echi 
2125 Cast of a mytilus, and counterparts, mass of bivalve shells, and slab of fossil wood, pierced by teredines, Sheppy

2126 Various petrifactions, echini, univalves

2127 Sundry fossil shells, casts of shells, \&c.

2128 A large mass of calcareous spar, having the surface coated with finely crystallised fasciated gypsum, Derbyshire

2129 Pale cubic fluor, sprinkled with rimarcasites, and having galena attached to it, Derbyshire

2130 Two fossil corals

2131 Part of a fossil stag's horn, fossil bone, and portion of a recent horn, found in moss

2132 A very singularly furcated fossil bone, supposed to be of some marine animal $-2-7-0$

2133 Part of a bone of a bright green colour, approaching to the turquoise, and, a tooth tinged with bright blue, both apparently impregnated with copper, and owing their colour to that metal, very curious

2134 Cast of a very large echinus, from Malta, rare 2

2135 A fossil bone of great size, supposed to be of some marine animal $/ 3$

2136 A large fossil grinder of an elephant, found near Warwick 8

2137 A small but extremely fine specimen of the regal purple feldspar, and another, in which/transverse golden strix appear imbedded in blue $/ 0$

2138 A fine specimen of the Franckenberg fossil, being a mixture of vitreous aud other copper ore 2

2139 Calcareous spar, with-coal; stalactitic spar, Gloucestershire; calcareous spar, Derbyshire; and another

2140 Two elegant varieties of copper ore, Bannat; a crystallized galena, Saxony ; and a galena, Derbyshire 6

2141 Specimen of pure plumbago, Borrowdale, Cumberland

2142 Needle antimony in white chalcedony, \&c. Hungary; and green phosphate of lead, Saxony

2143 Double refracting spar, Iceland; stalactitical spar, Italy; marble, Switzerland; and another

2144 Sparry incrustations, on a bunch of grapes, and an artichoke

2145 A large group of tetraedral blend, on yellow cubic fluor, Derbyshire

2145 Tabular barytes, with calcareous crystals

2147 An extremely elegant agate cup and cover, Germany

2248 White quartz, with black crystallised blend, and quartz with minute polyedral crystals of transparent blend, and galena, in octoedrals

2149 Galena, with quartz, blend, and dog's tooth spar, and a selenite, from Saxony

2150 A fine group of quartz crystals, Cornwall 
2151 Tetraedral blend, on quartz; purple cubic fluor, with blend, sprinkled with pyrites; and black blend, with quartz minutely crystallised in small aggregate globules

2152 An elegant specimen of finely crystallised gray cobalt, Hesse

2153 A polished specimen of the Herefordshire, pudding stone; in the center of one of the largest pebbles, is a strikingly accurate representation of a bird's head

2154 A beautiful box, formed of white jade-stone, China $\rightarrow$

2155 An interesting specimen of pink calcareous deposition, having the interior surface delicately crystallized, from the cobalt mines of Hesse, very rare $2-6$

2156 Bubbled pea-green calamine, solid black oxyd of coòalt, rare, Hesse; needle manganese, and antimony, Tuscany

2157 A capital group of rich brilliant galena, formed in large distinct cubes, Derbyshire

2158 A piece of Brasilian crystal, exhibiting tridescent colours of uncommon brilliancy, and clear pellucid crystal of ditto, with singular internal appearances

2159 A superb map-like variety of the iridescent labrador feldspar, 1. $1.0 \begin{aligned} & \text { richly variegated with ultramarine, golden orange, and } \\ & \text { fine pearly lustre, in the highest perfection }\end{aligned}$ 2160 A very elegant specimen of bubbled malachite, Bannat

End of the Eighteenth Day's Sale. 


\section{NINETEENTH DAY.}

\section{Monday, the 26th of May, 1806.}

2161 MoDel of a bark boat, Canada

2162 Saddle and stirrups, Morocco

2163 Mogul half boots, and Persian slippers

2164 Large and handsome tray, made of coloured straw, Mexico

2165 A figure representing a man playing on a flute, and another in a Hussar's dress, curiously executed with the wings of beautiful moths and butterflies, framed and glazed

2166 Two representations of opened books, one in oil, the other in water colours

2167 Painted cocoa nut shell, Mexico; and small coloured straw basket, from ditto

2168 Snow shoes, Hudson's Bay

2169 A group of fruit, elegantly represented in worsted work, framed and glazed

2170 Canadian shoes, and Chinese ditto

2171 Bengal slippers, and Hudson's Bay shoes

2172 Wing bones of the abatross, the joints connected by silver mounting

2173 Ornamented basket, Friendly Islands

2174 Syrinx, Otaheite; and flute, from ditto

2175 Chissel, New Zealand, formed of beautiful nephritic stone

2176 Fish decoy, Otaheite; cordage, from ditto; and a tattooing instrument

217\% Curious ornamental trimmings, Otaheite 
2178 Beautiful feather cap, Brazils

2179 Petticoat, S. Seas; anil sleeping stool, ditto

2180 A remarkably beautiful rich brown feather cloak, Sandwich Islands

2181 Two abbot's mitres, five various species of olivæ, a white venus's ear, and a bat music

2182 A fine orange-mouth ear-like terrestial shell, (voluta elongata, Soland.) New Caledonia, very scarce

2183 A fine chama cor, Linn. or fool's cap cockle, Sicily; and a cardium arundinosum, S. Seas-both rare

2184 A large lineated triplex, $W$. Indies; and a scarce variety of the muricated trumpet, China-both fine

2185 A large and fine horned snipe, Guinea, very scarce

2186 The vase murex, the luxuriant bulb, and a fine heavy turnep, having its epidermis

2187 A fine watering pot, from Sumatra, rare

2188 The page of honour cone, a large gold brocade cone, and a fine endive purpura

2189 The camp olive of extraordinary size and beauty, from Panama

2190 The ham pinna, of extraordinary magnitude, Sicily

2191 A scarce variety of the zebra trochus, the imperial crown cone, and a large brocade cone

2192 A spotted obelisk, S. Seas; the wheat-ear cuma, Guinea; two orange clouded needles, China; the banded subula, and a sanguineous mitre-all rare

2193 The gray music, from Guinea, very rare

2194. A large and fine alated variety of Argonauta Argo, Linn. or wrinkled paper sailor, E. Indies, rare

2105 A pied nerita, two pheasant snakes, a fine conus proteus, and two beautiful iris elenchi

2196 A large and fine voluta nobilis, firm China, very rare

21.97 The hare alatus, rare; and two fine olives

2198 The pied spondylus, adhering to an endive triplex, China; and a young specimen of the giant oyster, naturally affixed to a vulsella, Friendly Isles

2199 Five beautiful and scarce varietics of neritæ, E. Indies; and a ricbly coloured nerita sanguideus, very scarce, W. Indies

2200 A very large and fine oblong trapezium (Chama oblonsata, Soland.) Friendly Isles, extremely scarce. The inside is tinted with purple $2-3-0$

2201 Small ant eater

2202 Whole-fnoted pig, E. Indies

2203 Large two-toed sloth, S. America, Bradypus didactylus $\mid-6-0$

2204 Fox

2205 Twelve banded armadillo, Dasypus duodecim-cinctus

2206 Mungrel, betwixt a dog and wolf 
2207 Light yellow variety of the martin

2208 Marmot, N. American

2209 Striped Agouti, Surinam

2210 Black fox, Siberia

2211 Blue-fronted parrot, Brazils

2212 Recurvirostris avocetta /5

2213 Anas merula, fem. and wigeon, male, Hudson's Bay

2214 Curious full grown monster goose, having three legs

2215 Large robin, $m$. and fem. America; and larger swift, Gibraltar

2216 Woodcock variety, wagtail $\mathrm{m}$. and fem. and blue titmouse, m. and fem.

2217 Ardea ciconia, N. America $/ m / 2$.

2218 Gull, N. America, corvorant and white tern

2219 Hawk, S. Seas

2220 Ardea vittata, rare $-\infty$

2221 Bald buzzard hawk, N. America, m. and fem. $3-3-0$

2222 Crested goose 12

2223 Cassuary, Java, very large specimen

2224 Silvia superba, Botany Bay

2225 Cyrus crane, Bengal, very fine specimen

2226 Cuculus cinnamomeus S. America 15

2227 A very capital specimen of the rhinosceros bird, Buceros Rhinosceros, extremely rare $1 /-6,6$

2228 Red-breasted fly catcher, Botany Bay

2229 Boat bill, cancroma cochlearia, extremely rare, and in fine condition, without case

2230 A glass case, containing six extremely beautiful varieties of the pigeon $2 x-1>-6$

2231 Part of the Hordwell Cliff spindle, casts of univalves, anomiæ, echini, Sc.

2232 Voluta, Hordwell Cliff

2233 Four various echini, a mamillated echinus, and impres. sion of a pecten 100

2234 Sundry casts of univalve fossil shells

22,35 Nerite, Hordwell, serpula, casts of various shells, \&c. 2

2236 A large fossillized nerita, cast of a pecten, in flint; spine of an echinus, \&c. eight specimens

2237 Various fragments of fossil shells, belemnites, \&c. 3

2238 Fossil corals, shells, \&c. seven specimens $\rightarrow$

2239 Sundry shells, teeth of fishes, \&c. chiefly in flint and chalk

2240 Valve of a cardium, in chalk, pecten ditto, casts of various shells, \&c. 6

2241 Part of a large madrepore, petrified 3

2242 Twelve various casts of echini $12-6$

2243 Two mass of coralloids, and another zoophyte fossil 3

2244 Three large bones of some animal unknown

2245 Part of a rib-bone, imbedded in stone 
2246 Four fossils, including two madrepores, and two masses of turbinated shells

2247 Fossil stag's horn

2248 Trochus's pectens, and other fossil shells, nine specimens

2249 Various casts of ammonitæ

2250 Twelve various petrifactions, chiefly pectens, a mamillated echinus, \&c.

2251 Remarkably large and fine mass of Gibraltar rock

2252 Three specimens of sparry incrustations, from Carlsbad, Bohemia If

2253 A fine polished specimen of red fortification-like agate, Oberstein; and another of a white colour curiously ocellated 1

2254 A fine oriental mocha, ditto, with red dendritæ, ditto, Germany; onachine pebble, Scotland; and two specimens, from the Leverian chalcedony $2-2-\infty$

2255 A needle formed of beautiful green nephritic stone, or jade, from New Zealand $/ \mathrm{w} / \mathrm{s}$

2256 Two varieties of the great Leverian chalcedony, carnelian ring, Scotch agate, and German ditto $19-1$

2257 A curious box and cover of jaspachates, Oberstein $\Rightarrow C \cdot 0$

$225 \mathrm{~S}$ Nine specimens, among which are white opal; agate, with quartz crystal, curious jaspachates ; plate of polished amethyst, Oberstein; and purple chalcedony, Siberia on

2259 A fine slab of lepidolite, from Moravia

2260 Grey cubic fiuor, a large specimen, in small crystals, having one side of the surface coated with dog's tooth spar, Durham

2261 Uncommonly fine specimen of emerald green fluor, formed on a mass of white quartz crystals, Durham

2262 A large group of dark-coloured dog's tooth spar, with marcasites, and argillaceous fragments adhering

2263 A capital mass of magnetic iron, weighing above $1 \mathrm{cwt}$. Norway $20, / 2,5$ ?

2264 Part of one of the columnar rocks, from Dunbar. The Hormesion of Dr. Walker

2265 A very large horse-shoe magnet $1+4=8$

2206 Compact green zeolite, Palatinate; crystallized white and yellow carbonate of lead, on galena, Germany; and crystallized phosphate of lead, Saxony

2267 A fine specimen of cinnabar, the cavity of which contains native vermillion, Idria

$2268 \mathrm{~A}$ curious and rare specimen of a dark and bubbled substance, appearing like hæmatites, in basalt from Marburg; and vermicular chalcedony, E. Indies

2269 Yellow cubic fluor, a fine group, Derbyshire

2270 Compact gray cobalt, Hesse; hyalite, Franckfort ; and crystallized calamine, with crystals of sulphate of lead, Hesse

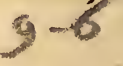


2271 Pink calcareous deposition, tinged by cobalt, Hêsse ; oriental lapis lazuli, steel-grained cobalt, Hesse ; and crystallized lepidolite, Moravia

2272 A finely crystallized galena, Saxony; and three other varieties of galena, Derbyshire, \&c.

2273 Transparent ruby copper, Siberia ; fine green sattin malachite, intermixed with ochreous iron ore, Siberia $h$

2274 Minutely crystallized galena, octohædral galena, with calcareous spar, Leicestershire; slickensides, Derbyshire; and crystallized galena, Saxony

2275 A fine specimen of crystallized bright green phosphate of lead, Saxony

2276 Wavelite, a new and recently discovered argilite, Chrysoprase, Silesia ; and tremolite, Switzerland /

2277 Kreutstein, or cross-stone, a very fine specimen, the crystals well defined, from Andreasburg, Hartz $/ 4 / \mathrm{w}^{2}$

2278 A curious box formed of an argillaceous stone, diversified with dendritical appearance

2279 Deep coloured oriental agate, with a beautiful opake white spot in the centre

2250 A group of very clear white columnar rock crystals, intermixed with others of a dark colour, some of them double pointed, from Mount Caucasus, in Persia $1 \mathrm{~m} / 0 \mathrm{~m}$

End of the Nineteenth Day's Sale. 


\title{
TWENTIETH DAY.
}

\author{
Tuesday, the 27th of May, 1806.
}

$2281 \mathbb{E}_{\text {MBRoldereD snake, boa phrygia, a fine speeimen, }}$ in spirit

2282 An amphisbæna fuliginosa, in fine condition

2283 Lacerta crocodilus, about five feet long

2284 A fine specimen of the manis, young, in spirit

2285 Gymnotus electricus, in excellent preservation

2286 Galliwasp

2287 Lacerta furcata, an excellent specimen

2288 Remarkably large and fine specimen of the rattle-snake, Crotalus horridus

2289 Lacerta chamelion

$2290 \mathrm{~A}$ beautiful and perfect specimen of the boa constrictor, in a glazed case

2291 White variety of the mole, $\mathrm{m}$. and fem.

2292 Grey squirrel, N. America

2293 White variety of the squirrel, N. America

2294 Virginian opossum, fem. Didelphis Virginiana

2295 Lesser opossum, fem. with young in the pouch/6

2296 Fulimart

2297 Black variety of hare $1-0=0$

2298 Fawn-coloured variety of ditto /t

2299 Chamois, from Switzerland, (fine specimen) Antilope rupicapra $4-1 / 4-6$

2300 An extremely large and fine specimen of the great anteater, South America, myrmecophaga jubata 
2301 Canary bird, yellow wagtail, reed sparrow, and nun titmouse-four cases

2302 Black-breasted plover, N. America $/ 2$

2303. Red shanks, and green finch-two cases

2304 Least wood-wren, twite hen, and goldfinch-three cases

2305 Jay, N. America, Corvus cristatus $\rightarrow$

2306 Black linnet, Africa; and green sparrow, Surinam-two cases it:

2307 Gray plover, and woodcock-two cases 1.1 .0

2308 Red-headed smew, m. and fem. Mergus minutus 1.4

2309 Scull of a babyrousa

2310 A fine and curious specimen of the pea-hen, which in its eleventh year put forth the plumage of the male bird 3

2311 Sandpiper, and an Avadavad bird - two cases 5.6

2312 A very fine female swan $/ \cdot 3 *$ s

2313 A ditto male swan ㄴ. $f-1,40$

2314 Titlark, yellowhammer, m. and fem. and wrens-three cases

2315 Yellow-fronted small parrot

2316 Red-headed tanager, Tanagra gyrola

2317 Grasshopper lark

2318 Goatsucker, m. and fem.

2319 Ardea minuta, extremely rare

2320 Muscovy duck, m.fem. and young, beautifully preserved

2321 Two fragments of a plant of the reed kind in free-stone, part of a vegetable impression in argillaceous iron, and another in coal slate 10

2322 Eight various fragments of vegetable barks

2323 A pecten in chalk, part of a mamillated echinus, and a fossil madrepore

2324 Two vegetable impressions, in coal slate, one of bark, the other fern $10-0$

2325 Mass of various fossil shells, and a large slab with casts of turbinated univalves 2

2326 Part of a belemnite in flint, an anomia, two pectens, and two other fossils in chalk $>$

2327 Several pectens, cunei, a mya, and other fossil shells, nine specimens $2-0-0$

2328 One very clear and well-defined impression of bark in coal slate, and another ditto

2329 Three impressions of barks, one of them in sandstone 33

2330 A pecten in chalk, and a single valve ditto

2331 Three vegetable impressions of barks, in coal slate

2332 Fossil remains of two bivalve shells, one a hollow cast ex hibiting the impressions of spines

2333 Ornamental ivory model of a temple, and model of a guillotine, made by a French prisoner

2334 Carved ostrich egg 
2335 Singular lusus naturæ in wood, resembling a bird, and singular walking stick

2336 A pair of bronze figures, from Herculaneum

2337 Curious wicker coffee urn, China - b

2338 Ornamented body of a glass hooker $/$

2339 Curious specimen of raised card, cut with a penknife by Mrs. Rudge, handsomely framed and glazed / 3

2340 Large Chinese stringed musical instrument

2341 Persian target

2342 Tom Tom drum, from Bengal 5

2343 Chinese characters and figures, executed 'by Mr. Cox's celebrated mechanical automata, handsomely framed and glazed

2344 Remarkably delicate and well-excuted dissections of leaves, by Mr. Dobson

2345 Insects excuted in shell-work in a glazed frame

2346 A Turkish Firman, with the autograph of the sultan; together with four Turkish coins, in a glazed mahogany case

2347 Figure of a dog, beautifully executed in veined marble-a very fine piece of workmanship $3-1,2$

2348 The placuna ephippium, Soland. or saddle-shell, from Tranquebar, scarce

2349 The thick-lipped frog, Madagascar; a young cocoa-nut, fresh water-shell, Barbadoes; two of the gibbous olive, China; two cones, and three others

2350 A high Adrniral cone, the skeleton purpura, and a brown hedge-hog-all rare is

2351 A very large Neptune's trumpet, (Murex Tritonis Linn.) betivtifully colcured, Otaheite

2352 The bat volute, of a brownish red colour, and of extraordinary size, Ceylon $/ 0-0$

2353 The great brown Asiatic serpula, China; and two fine keeled snakes, Friendly Isles-both kinds rare $/ .0 \cdot 0$

2354 Two knotted clubs, Guinea; two zigzag olives, a scarce landsnail, a rare banded mitre, and two rare needles

2356 The clourled melon, (voluta cymlrium, Linn.) Guinea, rare; and a fine triangular buccinum, $W$. Indies $/ \infty$ a

2357 A very large and fine nautilus pompilins, Linn. China / -

2358 The mainsail alatus, (Stromlus epidromis Linn.) the black music, Guinea; and the W. India music-all large and fine

2359 The keeled snake, Friendly Isles; another scarce snake, S. Seas; the pomegranate sea-snail, Cape of Good Hope; and a large bull's eye snail, $N$. America $/ 3-6$

2360 A very fine cardium Janus, or two-ways striated cockle, Friendly Isles, extremely scarce $2 \cdot 3 \cdot 0$

2361 A large and fine yellow chersina; with a white band round the spire, and striped with brown, and another of the

$$
y+1>-6
$$


same kind, but a reverse shell-both from Princes Island, and rare

2362 Cardium aculeaturn, Linn from Sicily; Arca antiquata, Linn. S. Seas; a fine striated fig, Tranquebar; and a young spider strombus, China

2363 The tiger trochulus, New Zeuland, very rare

2364 The Oriental purp!e-mouth alatus, very rare; the brown variety of oliva protea, and another scarce olive

2365 Two wentle-traps, the lesser weaver's shuttle, the aurated and spined neritellæ, and twenty other curious small shells, \&x. $>-6$

2366 A muricated trumpet, Madagascar; and an American fig, called the Pugilist's fist

2367 A fine chersina zebra, a scarce terrestial shell, from the Cape of Good Hope

2368 A large specimen of ferruginous dog's tooth spar, Bath

2369 Six specimens, amony which are peacock copper, Cornwall; yellow' copper, Sweden, \&c.

2370 Piedra d'Ynca, and various other minerals 5

2371 A fine specimen of rery light-coluured arseniate of cobalt, Hesse $+y-6$

2372 Dog's-tooth spar with ferruginous coating, calcareous spar, pale fluor with blend and marcasites, Durham

2373 Crystallized blue malachice, Bannat; antimony, Tuscany; green phosphate of lead, Saxony; and laminated galena, with copper ore, Sweden

2374. Crystallized carbonate of lead, partly coating a decomposed galena; native mercury, \&c. in a quartzose matrix, Idria; a large crystal of galena (partially decomposed) on pearl spar, \&c. and three others

2375 Cross-grained galena, containing silver intermixed with spar, from Salbergt Grufen in Sweden; and very fine laminated galena, with copper ore, from ditto; and two galenas with cubic fluor, Derbyshire 3 -

2376 Large specimen of hæmatites, Lancashire; spathose iron ore; large specimen of Bristol quartz crystals, and crystallized galena

2377 Eight specimens, including cobalt and nickel, Thuringia; native orpiment, apple green oxyd of nickel, rare; white and ferruginous spathose lead ore (containing silver) with blend, from Weidberg, in the province of Bergues, and four others

2378 Rhomboidal iron spar, manganese on hæmatite, iridescent iron ore, Triers, and a galena 5

2379 Eleven various specimens, including steel-grained iron ore with red jaspar; black hæmatites, with a beautifully gilded surface, Germany; maguetical octohædral crystal of iron ore, Corsica, \&c. $;-1 \cdots 0$ 
2380 Galena, forming confused veins in a broken white cauk, the fragments of which are united by white fluor, Derbyshire; splathose lead ore, galena with calamine, Derbyshire, and another

2381 Honey-comb like amcthystine and yellow fluor being part of a nodule, cut and polished, Derbyshire

2382 Solid blue carbonate of copper, and crystallized blue and green malachite, Bannat

2383 Nine specimens, among which are a curiously variegated carnelian, and three handsome agates

2384 Cubic amethystine fluor of a dusky hue, nearly approaching to black, Derbyshire

2385 Delicate green cubic fluos, partially coated with minute quartz crystals and dark brown pearl spar, Durham 70

2386 Delicately crystallized calcareous deposition, Hesse; and crystaliized carbonate of lead, of a bright blue colour, Hartz 4

2387 Whitish cubic fluor, with blend; galena, and calcareous spar, Derbyshire

2388 Two specimens of pudding stone -9

2389 Two specimens of sardonyx, and three of agate $/-2-6$

2390 Seven specimens, among which are ocellated agate, yellow and white onyx, and Siberian carnelian 10 as

2391 Egyptian pebble, oriental sardonyx, and four agates

2392 Fluors in amethystine cubes variegated with white, Durbam

2393 A beautiful red and white onachine carnelian, and wax opal, Hungary

2394 A large mass of the apple-green variety, of iridescent labrador feldspar

2395 A fine specimen of steel-grained cobalt, having the surface covered with red and yellow oxyd of ditto, Hesse ; and argentine galena, with crystals of gray copper, Hartz

2396 Cinnabar, with native vermillion, Idria; and a very fine specimen of crystallized gray brilliant cobalt, Hesse

2.397 A fine specimen of bubbled calamine, having in it cavities well defined crystals of sulphate of lead, Hesse

2398 A very large and clear topazine crystal, cut and polished, Brasil $\Rightarrow$

2399 A fine specimen of olivin in basalt, Hesse

$2400 \mathrm{~A}$ very fine and large specimen of rose-coloured arseniate of cobalt, with pharmacolite, on the surface of a decomposed looking-glass cobalt, Hesse

\section{End of the Twentieth Day's Sale.}




\title{
TWENTY-FIRST DAY.
}

\author{
Wednesday 28th May, 1806.
}

$2401 \mathbb{V}$ AR Club, North America; and Chinese fan

2402 Persián bow

2403 African war instrument, made of conjoined antilope horns

2404 Gigantic Polar bears foot, cut from the animal whilst attempting to board a boat; and a large antilope's horn

2405 Long jumping pole and spear, used by the Chouans in France to escape from their pursuers

2406 Shaving bason of Persian ware

2407 Large glass vessel, ornamented with the imperial eagle, and a great variety of heraldic bearings, \&c.

2408 Bronze figure, Herculaneum

2409 A pair of grotesque bronze figures, E. Indies

2410 Ancient English watch

2411 Ditto large blue and yellow dish

2412 Egyptian urn (with ibis bones inclosed)

2413 Large and singular Gerınan pipe

2414 Singularly knotted walking stick

2415 Remarkably large saw of saw fish

2416 Large specimen of Otaheite cloth

2417 Black and white fly-catcher

2418 Larger bramlin, titlark, canary bird, and robin-four cases

2419 Yellow wren, America

2420 Humming birds, $m$. and fem. with nest

2421 King’s-fisher, Alcedo ispida

2422 Minor grakle, Gracula religiosa 
2423 Long-tailed green jacamar, Alcedo galbulu, var.

2424 Water ouzel, $m$. and fem.

2425 Silver pheasant, mas. Phasianus nycthemerus

2426 Larger sanderlin

2427 Psittacus tabuanus, a very fine specimen

2428 Woodchat, very rare, Lanius rufus

2429 Dottrel, and marten, m. and fem.-two cases

2430 Great crowned pigeon, Columba coronata

2431 Spotted woodpecker, N. America, m. and fem.

2432 Water-hen, South Seas

2433 Cuckoo, m. and fem. Tobago

2434 Toucan, Brasil, Rhamphastos rufirostris

2435 Red-bellied woodpecker, America, Picus hirundinaceus, var.

2436 Trumpet bird, S. America, Psophia crepitans

2437 Mya corrugata, Brasil, rare; and a large and fine cock's wing clam, from Ceylon

2438 The ribbed or goose-wing lurker, (Pholas costatus, Linn.) S. Caroliana, rare; and the painted mussel (myt. pictus, Soland.) Mediterranean

2439 Spondylus undatus, very scarce, Tranquebar; and a deeply indented purple cockscomb oyster

2440 A reverse helix, from Guinea; the variegated brown French horn, Pulo Condore; and the hair-streaked bulla, from Cliina, all rare

2441 The short-rayed sun, a scarce trochus, a stair-case, a tun with a singular margin, and two scarlet spotted mulberries

2442 The angulated turnep, Florida; and a large conus aulicus, Amboyna, both rare

2443 Two of the great white Asiatic serpula, S. Seas; a large and fine cochlus smaragdinus, $N$. Zealand; and a pomegranate sea snail, partly uncoated, from the Cape of Good Hope

2444 A curious orange and scarlet variety of spondyius armatus, having large foliations on the under valve, Martinique, rare

2445 A fine onustus maximus, or great carrier, loaded with shells and corals, from Martinique, very rare

2446 The papal mitre of an uncommon size, from Amboyna; and the great swamp club, from China, both rare

2447 A large rasp cockle, (cardium Isocardia, Linn.) from $\mathrm{Ja}$ maica; and a large pectunculus cribrum, or sieve clam, from China, both rare

2448 A large and fine alatus of a rare species, Providence

2449 The white hammer margaritifera (ostrea malleus, var. Soland.) Haynam, very scarce 
2450 An aculeated snake, China; another rare senectus, Mada. gascar; and a scarce triplex, Tranquebar

2451 A lineated mitre, S. Seas; two ruffled mulls, Jamaica; two banded chersinæ, Otaheite; two cock-chafer ear snails, and thirteen other curious small shells

2452 Solen rostratus, Soland. Nicobar Isles; and a duck's foot scollop, W. Indies, both rare

2453 An iris ear of extraordinary size, New Zealand

2454 The great undulated helmet of extruordinary magnitude, and very fine, W. Indies

2455 The green vulsella, S. Seas, extremely rare; and the black vulsella, Friendly Isles, also rare

2456 A fine lucerna auricularia, or ear-like lamp snail, extremely scarce

2457 The full bottom monkey, Simia comosa, very rare

2458 Simia Capucina, Capucin monkey, rare

2459 Silky monkey, Simia rosalia, Brasils

2460 The Chinese bonnet monkey, grotesquely set up, (in imitation of a shoemaker)

2461 The vocal performer ditto, Simia rufa

2462 Simia jacchus, sanglin monkey, America -6

2463 Simia hamadryas, grey baboon, in a handsome glazed case. a very fine specimen, rare

2464 Simia pithecia, fox-tailed or friar monkey

2465 Simia sabæa, male and female, small green monkey

2466 A sepia, a species of prionus, several larvæ of the sphinx tribe, and the larva of a coleopterus insect, in four bottles

2467 Tarantula, several specimens, a lucanus, two singular caterpillars,' \&c. in six bottles

2468 A remora, section of an oyster, a banded snake, and another, in four bottles

2469 Ocypode rhomboidea, flying squirrel grylli, an embryo, and a muricated testudo

2470 Esox belone, cyclopterus rostralis, various crustacea, and two others, in all five bottles

2471 Lophius histrio, a scorpion, a lizard, and two fishes, in all five bottles

2472 Lacerta monitor, in excellent condition

2473 Four various impressions of vegetable bark, two in micaceous sand stone

2474 Four impressions of vegetable bark

2475 Fossil stag ${ }^{\circ} \mathrm{s}$ horn

2476 Part of a large bone, supposed to be of an animal of the lacerta tribe,

2477 A large echinus imbedded in a nodule

2478 Various fragments of teeth, spine of an echinus, \&cc chiefly from Stonsfield 
2479 Part of a curious fossil palate of a fish $;$ ancther smaller, and a portion of a recent one

2480 Very large orbicular group of hexagonal spars, Derbyshire

2481 Two parts of a large bone of an unknown animal ${ }_{8}$

2482 Two parts of a singular jaw of an animal unknown, small

2483 Five impressions of vegetables, various

2484 Part of a large vetebral bone of a large animal, supposed of the alligator kind

2485 Large fragments of an ammonite, shewing much of the internal structure

2486 A large cube of amethystine fluor of a dark purple, studded with small brilliant double-pointed crystals, from Durham

2487 Fasciculated gypsum, Derbyshire, lepidolite in quartz, barytes, in plates, dittc, with calcareous spar, and two varieties of sulphate of strontian

2488 Hacked quartz, Germany; and five specimens of quartz, crystallised

2489 Zeolite, with calcareous spar, Andreasburg, Hartz

2490 Jasper, ribband jasper, jasper from Baden-Durlach; decomposed jaspar, and another

2491 Hacked quartz, Germany ; calcedony, Bristol ; diamonds, black shorl in quartz, and two more

2492 A fine bluish agate, ditto red, and a peb,ble polished

2493 A specimen of iridescent labrador feldspar, richly variegated with purple apple-green and blue, a combination of colours extremely rare in labrador

2494 A large specimen of jaspideous wood partly polished

2495 Galena, with mamilated cauk, mica in quartz, Lancashire; stellated gypsum, Sheppy; barytes, with calcareous spar, quartz with purple fluor, and iridescent coal, Lancashire

2496 Nine specimens of brilliant marcasite, one on cauk, and one cockcomb

2497 A large slab of slate, studded with brilliant cubic marcasites, England

2498 Aqua marine, cubic fluors, sprinkled on the surface with brilliant quartz crystals, Durham

2499 Plumbago, Cumberland; white muriate of antimony, Bohemia ; nickel, in quartz, Siberia'; and three others

2500 A very delicate and elegant specimen of calcareous deposition, of a moss-like appearance, and a rose-coloured compact calcareous deposition, both from the cobaltmine; of Hesse, and very rare

2501 Green fluor, in large crystals, Cornwall

2502 Piedra d'Yncia, or royal stone, China; and various other marcasites

2503 Capital group of fourteen-sided crystals of galena, with crystallised blend, white cubic fluors, internally sprinkled with marcasites, and having bevelled edges; \&c. Derbyshire 
2504 Eight small specimens, including native arsenic with crys tallized realgar; yellow phosphate of lead; crystallized native cinnabar, Hungary; antimony, Tuscany, \&c.

2505 Brazilian topaz in its native state, and ditto cut and polished

2506 Black stalactitical iron ore, Triers; and brown spathose iron

2507 Solid brown spathose iron; iron ore, with minute quartz crystals, \&c. Triers; stalactitical iron ore, Forest of Dean; and antimony, Tuscany

2508 A capital gtoup of white cubic fluors, Derbyshire

2509 Hollow argillaceous iron ore (two specimens) septarium, or divided iron ore, Triers ; and a ditto compact, from ditto

2510 Twelve various specimens, including realgar, orpiment, bismuth, cinnabar, \&c. \&c.

2511 Galena, rich in silver, from Salberg, in the province of Westmannia, Sweden; and laminated ruby silver on quartz, Germany

2512 Crystallized green and brown horn lead ore, with galena, ochre of lead and iron ore, and green efflorescence of copper on quartz, Schlangenberg, Sileria

2513 A very fine specimen of twelve sided spar, from Derbyshire 2514 Ribband jaspar, Siberia $\angle-6$

2515 Lapis lazuli, a large specimen, cut and polished, Siberia 5 2516 A capital specimen of galena, the surface richly glossed with iridescent appearances, Derbyshire

2517 Strongly magnetic iron ore, or loadstone; and solid black ha:matites

2518 Spathose lead ore, with copper ore, on an ochreous iron ore, Siberia

2519 A small specimen of native minium, or red lead on a white and red spathose lead ore; galena, and quartz, Siberiaextremely rare

2520 An elegant specimen of crystallized white carbonate of lead, on yellow ochre and quartz, Scotland; manganese in minute crystals, on hrematite; and crystallized spathose iron

End of the Twenty-first Day's Sale. 


\section{TWENTY-SECOND DAY.}

Thursday, the 29th of May, 1806.

2521 SLING, fish hook, fish decoy, chisel, and cordage, Otaheite

2522 Large roll of cordage, from ditto, and a fish-skin file

2523 Meat dish and sleeping stool, from ditto

$2524 \mathrm{Comb}$, tattooing instrument, and fish decoy, Otaheite ; and large fish-hook, New Amsterdam

2525 Chissel, New Zealand, made of green jade, or nephritic stone

2526 Guitar-like instrument, China

2527 Very large crnamented parasol, E. Indies

2528 Ancle ornament made of shells, Sandwich Island

2529 Basaltic adze, from ditto

2530 Feather necklace, and bracelet made of boars tusks, from ditto

2531 Resemblance of a woman and child, carved in wood, Otaheite

2532 Small bracelet made of dogs teeth

2533 Fishing implement, Nootka Sound; comb from ditto; and hemp beater, made of bone, from ditto

2534 Elegant cap, with a carved-ornament made of bone, Onalaska

2535 Puff, resembling a powder puff, but which is filled with delicate white down. The natives of King George's Sound puff the down on their hair by way of ornament 
2536 Elegant fur girdle, King George's Sound ; and ornamented knife case, from ditto

2537 False hair, worn for ornament by the natives of the Friendly Islands; and four bowls for playing with, made of whetstone, \&c.

2538 Stone pestle for pounding the bread fruit into paste, Otaheite; and a specimen of the bread fruit grown in Dominica

2539 Dancing rattle, shaped like a bird, Nootka Sound

2540 Large ornamented gourd bottle, Sandwich Islands

2541 Ferret, m. fem. and young

2542 Raccoon; Ursús Lotor

2543 Cat, Cape of Good Hope

2544 Civet cat, Viverra Civetta

2545 Finely preserved fœtus of the sea cow, Trichecus rosmarus

2546 Arctic fox

2547 Large brown rat, two specimens, and largest weasel

2548 Gray squirsel, two specimens

2549 A group of the common hedgehog, $\mathrm{m}$. fem. and young, consisting of eight specimens in various attitudes

2550 Lynx, Felis Lynx

2551 A belemnite imbedded in stone, part of a pecten, fish bones, and another

2552 Impression of the skeleton of a fish, Verona; part of a fossil tortoise, madepores, \&c. six specimens

2553 A large mass of fossil coral, allied to tubipora musica

2554 A large mass of sulcated bivalve shells, Stonsfield

2555 Fossil coral, Colebrook Dale, a large specimen

2556 Impression of the skeleton of a fish Papenheim, two sharks teeth, tooth and bufonite, \&c.

2557 A large aggregation of entrochi on limestone, Derbyshire, a fine specimen

2558 Nine various fossil shells, coral in flint, \&c.

2559 Fragments of encrini in marble, Derbyshire; ditto of a madrepore, Derbyshire; an ammonite, ostrea, and two more petrifactions

2560 A mass of sulcated anomiæ, Derbyshire

2561 Picus viridis, two specimens, and canary birds, three specimens, (two cases)

2562 Sea lark, Gibráltar

2563 Water hen, N. America

2564 Woodchat, Lanius rufus

2565 Thrush, Christian's Isle, under the Line

2566 Tanagra violacea, golden tanager, $\mathrm{m}$. and fem.

2567 Large black tern, N. America

2568 Black-bellied darter, Plotus melanogaster

2569 Woodcock variety

2570 Merops apiaster, m. and fem. 
2571 Haw finch, and cuckow, young, two cases

2572 Teal, Surinam

2573 Hedge sparrow variety, and common sparrow variety, two cases

2574 Titlark variety, and summer titlark, $\mathrm{m}$. and fem. two cases

2575 Boat-tailed grakle, Gracula barita

2576 Blue-bellied finch, two specimens

2577 scarlet-rumped parrot

2578 Yellow breasted toucan, S. America, Ramphastos aracarioides

2579 Firefinch, Africa, two specimens

2580 Red-tailed tropic bird, Phaton phenicurus

2581 Two of the short-spired French horn, from Pulo Condore; and another scarce oriental land snail

2582 A large diadem echinus, W. Indies; two others, and a clypeated echinus, from the English coast

2583 A large and fine bear's paw clamp (Chama hippopus, Linn) E. Indies

2584 A long clamp; Madagascar; and a scarce black pinna, $S$. Seas

2585 The occidental argus porcellanæ, ditto in a young state, a woodcock's head triplex, two other shells, and an operculum of the grèat marbled snake

2586 A small nautilus pompilius, openéd to shew the cells, a ruby-eyed patella, an American fig, and six others

2587 The brown club-spined echinus, St. Mauritius, rare

2588 The clouded' Persian crown melon (Voluta amplora, Sóland,) of great magnitude, being twelve inches and a half in length, brought from the norlhern part of N.S. Wales, by Capt. Cook $\cdots$

2589 Two harps, a tent limpet, a tulip balanus, two ears, and three others

2590 A thorny snipe's head purpura, with an oyster adhering, from Sicily; a brunette, and two other porcellanæ, and two tellens

2591 The compressed breast snail, Haynam; a reverse brown lielix, Guinea; two occidental suns, a lapwing egg bulla, and a spotted tun.

2592 Two panther cones, a red bulla, four olive, and two others

2593 A painted clam, a scarce pinna, a South Sea margaritifera, a chequered fig, a beaked fig, two other univalves, and two large hurny opercula of shelts

2594 The long furbelowed clamp (chama elongata, Soland.) from Madagascar, and iwo large and fine porcellanæ

2595 Various spines of echini, two of them of an extrem dy rare specics; unknown in its complete state

2596 A strawberry cockle, two other bivalves, a harp, a lantern buccinum, and four other porcellanx 7,6 
2597 A large and fine spotted melon (Voluta melo, Linn.) China

2598 The foliated rhombus, Falkland's Island, rare; the lineated trumper, New S. Wales; and the muricated trumpet, Tranquebar-all fine

2599 Two varieties of the striated cone, and a gold mouth senectus

2600 A large and fine Midas's car land shell, (Yoluta auris Midæ, Linn.) Malacca, very rare

2601 Black spathose lead ore, Germany, rare; steel-grained galena, Hartz; gray copper, ditto, and ruby vitreous silver, ditto

2602 Brilliant gray cobalt, interspersed through barytes, Hesse; and solid dull ditto, with minute yellow crystals, from ditto

2603 A fine and large specimen of pharmacolite, part delicately stellated, Hesse

2604 A fine specimen of hyalite, Franckfort; a ditto of rose-like gypsum, Hesse; and a nodule of agate and amethystine quartz, in the centre of which is calcareous spar, and delicately bubbled chalcedony, Palatinate 6

2605 Light coloured moss-like native gold, Hungary ; crystallized dark coloured vitreous silver, Hartz; fortification cobalt, Hesse; dendritical copper nickel, ditto

2606 Laminated ruby silver on pink barytes, Hartz; and laminated muriate of silver

2607 Bubbled and crystallizéd phosphate of lead, Saxony; and hornblende in silvery micaceous schist, Spain the

2608 Efflorescent zeolite in the cavities of a decomposed almond stone, Hesse

2609 Very fine steel grained gray cobalt, Hesse; and crystallized cobalt, ditto

2610 Brilliant crystallized gray cobalt, Hesse ; gray copper ore, with green and blue malachites, Hartz

2611 Egight various vegetable impressions in slate

2612 Fragments of the vertebra and ribs of a large animal supposed to be of the alligator kind

2613 Laminated limestone, with vegetable impressions

2614 A large piece of fossillised madrepore, cut and polished

2615 Four reticulated stems of vegetables, fossillised

2616 Blacle-bone of a large animal; said to be the hippopotamus

2617 Vegetable impressions in coal slate, and three pieces of fossil wood

2618 Aggregate of fossils in line stone, exhibiting a portion of the stem of an encrinus

2619 A large mass of marine remains, fossillised, Dudley $3-6$

2620 Two large striated pectens compressed on a piece of limestone, Bristol 
2621 Three impressions of vegetable barks, and stone, with wood imbedded

2622 Cast of a gigantic shell of the univalve kind, France

2623 A large mass of stone, with impressions of several vertebral joints, supposed to be of an animal of the alligator kind, Bath

2624 Five impressions of vegetables, in nodules of argillaceous iron, and two barks, in coal slate.

$2625 \mathrm{~A}$ fine and large fossil madrepore

2626 A singular mass of petrificd oysters

$2627 \mathrm{~A}$ mass of petrified remains of shells, \&c. including a species allied to the dentalium tribe

2628 A singular cast of a sulcated shell, apparently a bivalve

2629 A curious madrepore fossillised

2630 Fragment of timber, found imbedded in stone, and another piece of fossil wood

2631 Beautiful green zeolite, cut and polished, Palatinate; and solid gray cobalt, Hesse

2632 A superlatively fine slab of iridescent feldspar from Labrador, very richly variegated with crimson, orange, and purple, and slightly speckled with blue

2633 Cinnabar, with bright native vermillion, Idria; pharmacolite, with red arseniate of cobalt, Hesse; deep red arseniate of ditto, Saxony; crystallized calcareous spar on galena, Hartz $/$

2634 Uncommonly large and very fine specimen of the Franckenberg fossil, being a mixture of vitrecus and other copper ores 5

2635 Wolfram, Bohemia ; crystaliised ruby silver, Hartz; fortification cobalt, Hesse; and delicately crystallized calamine, ditto

2636 Purplish, pink, and red arseniate of cobalt, Hesse; and hæmatitic cinnabar, Idria

2637 A capital specimen of the variety of copper ore, termed kupfer-branderz by the Germans, being a combination of copper, with bituminous matter, very rare, Hesse

2638 A very fine specimen of olivin, in basalt, Hesse

2639 A large and fine specimen of silvery calcareous earth, (glanzerde of the Germans) in a gray argillaceous matrix, Hesse.

2640 A large and superb specimen of fortification cobalt, Hesse

End of the Twenty-second Day's Sale. 


\title{
TWENTY-THIRD DAY.
}

\author{
Friday, the 30th of May, 1806.
}

2646 An eyelet hole mat of a very curious construction, the holes not being cut out but formed in the process of making, Friendly Islands

2647 Model of canoe, King George's Sound

2648 Rattle, shaped like a bird, ditto

2649 Scoop made of horn, from ditto

2650 Squirrel skin waist ornament, Cook's River

2651 Carved bone truncheon, Nootka Sound

2652 Elegant feather fly flap, Sandwich Islands

2653 Red and yellow feather cloak, from ditto

2654 Singular war weapon, Nootka Sound

2655 Large and fine piece of matting, Sandwich Islands

2656 Feather helmet, from ditto

2657 Instrument set with shark's teeth, from ditto

2658 Three necklaces made of shells, \&c. and a feather ditto, from ditto

2659 Leg ornament, formed of shells, from ditto

2660 Long and very handsome spear, formed of a maboganylike wood, from ditto

2661 Vegetable lamb, and Paddy or E. Indian rice in the husk 
2662 Part of a branch of the legatto tree, shewing the curious lace-like bark

2663 Flower of a curious thistle, under a bell glass

2664 Large and fine specimen of gum serregal, from the coast of Guinea

2665 Guinea corn, and seed vessel of the sand box tree, W. Indies

2666 Specimen of Otaheite sugar cane

2667 Horse shoe, partly inclosed by the spur of an ash tree which grew round it

2668 American wheat, of various colours, in a glazed case

2669 Everlasting flowers, Cape of Good Hope; and curious stellated ditto

2670 Bone, naturally inclosed in solid oak

2671 Marten, $m$. and fem.

2672 Armadillo, $\mathrm{m}$. fem. and young

2673 Lion, bred in the Tower of London

2674 Squirrel, N. America

2675 Small red squirrel, from ditto -.

2676 Hog deer, Princes Island

2677 Goat

2678 Radiated mole, America

2679 Wild cat, killed near Combe Abbey, Warwickshire

2680 Antilope, $\Lambda$ frica

2681 Painted finch, America, $m$. and fem.

2682 Beautiful variety of the bulfinch, var. $B$.

2683 Blue creepers, S. America

2684 Long-tailed creeper, $m$. and fem.

2685 Blue finch S. America

2686 Red-headed manakin

2687 Black finch, Africa

2688 Minor grakle, E. Indies, Gracula religiose

2689 Smew, male

2690 Spur-winged plover, S. America

2691 Ground-dove, W. Indies, three specimens

2692 Red-backed shrike, m. fem. and three young, Lanius collurio

2693 Cross-billed fieldfare

2694 Large black and white woodpecker, m. and fem.

2695 Yellow-headed thrush, S. America, $\mathrm{m}$. and fem.

2696 Small Lory, E. Indies

2697 Gray-headed parrot, E. Indies, $\mathrm{m}$. and fem.

2698 Cinereous wattle bird, S. Seas, Glaucopis cineria

2699 Yellow woodpecker, Picus exalbidus

2700 Cassuary, N. Holland, (without case)Cassuarius nor. Hollandia.

2701 A very large aculeated cassidula, $W$. Indies

2702 I'wo black-mouth cochlere, Portugal; two plaited and. two other mitres, a lapwing's egg bulla, and two cones 
2703 A brown spiral worm adhering to a madrepora Virginea, $W$. Indies ; two groups of serpula, two caducæ, and two groups of balani

2704 A large chama gigas, Linn. or giant clamp, from Ceylon

2705 A fine zebra chersina, a scarce terrestial shell, from the C. of G. Hope 10

2706 The orange variety of the duck's foot scallop, COstrea nodosa, Linn.) a royal mantle pecten, (ostrea Pallium, Linn.) and an Iris ear

2707 The leopard cone, a brown porcupine, and the groom cone

2708 The mottled hound's ear margaritifera, Friendly Isles, very scarce

2709 Two echini placentæ, one with two holes, the other with five; five species of diadem echinus, and an oval turban echinus $9 \%$

2710 The long-spired neritella, (Neriic corona, Linn.) River Ganges; and a pair of conus corallinus, Soland. or little English Admiral cone, W. Indies - both kinds rare

2711 The boat melon of uncommon magnitude, being upwards of 13 inches in length, Guinea

2712 A fine conus fulgens, the girdled cone, and a red mouth endive triplex

2713 A fine onustus maximus, or great carrier, loaded with shells, from Martinique, very rare

2714 The undulated helmet, $W$. Indies; and a large young cornuted helmet

2715 The banded argus frog, C. of Good Hope, rare; a banded tun, China; and a flag cone, S. Scas

2716 Section of a nautilus pompilius, and a fine spider strombus, from China

2717 A very large and fine chersina tigrina, from Guinea, rare

2718 Cassida porcata, or ridged helmet, (Buccinum porcatum, Soland.) remarkable for its margin or lip being 1 inch and a $\frac{T}{4}$ broad, and for the fine colour of its mouth, Mediterranean

2719 A very fine Voluta arausiaca, Linn. or Prince of Orange's

$-10-0$ flag music, in a young stage of growth, from Amboyna

2720 The violet ringed and starred echinus, with a double annulation, from China, very rare

2721 Large upper valve of an ostrea, and part of a pecten, with several adhesions of small shells

2722 Part of the upper valve of a pecten, impressed on chert, curious, from France; and a portion of the Sheppy Island nautilus

2723 Fragments of bones especially teeth imbedded in calcareous spar, Gibraltar-a very interesting specimen

2724 A variety of small specimens of vegetables, in coal slate, fossil wood, \&c. 
2725 An echinus, cast of a pecten, spine of an echinus, fish palate, \&c. in chalk

2726 Eleven various specimens of fossil vegetables $2-5$

2727 Casts and parts of echini, in chalk and flint, various; cast of a trochus, and several univalves

2728 Two casts of pectens, and their counterparts

2729 A great variety of curious fossil shells, from Hordwell Cliffs, and France

2730 Reversed whelk, and another, casts of echini, \&c,-in all nine specimens

2731 Casts of spines of echini, in chalk, \&c. a whelk, two patellæ, \&c.

2732 Cast of a pecten, in flint; two anomiæ, in chalk; a patella, spines of echini, \&c.

2733 Fourteen petrifactions, as teeth of fishes, a palate, anomia, - \&c. most of them in chalk

2734 Seven various impressions of fossil plants, barks, leaves, \&c.

2735 Casts of three fossil pectens, one with the counterpart, and a tuberculated cuneus

2736 A variety of different casts of shells, chiefly turbinated univalves

2737 Nine various petrifactions of shells, casts of shells, \&c. $/ 2$

2738 A variety of shells, spines and fragments of echini, Sc.

2739 Minute fossil shells, found in Belvoir Vale, Leicestershire

2740 Casts of pectens, ostreæ, \&c. in chalk, echinus in flint, shells, sxc.

2741 White cubic fluor, with bevelled edges, sprinkled with minute marcasites, and combined with crystallized galena and blend, Derbyshire; and very dark amethystine fluor, from ditto

2742 Four elegant varieties of fluor, cut and polished, Derbyshire

2743 Elegant specimen of purple cubic fluor on white quartz crystals, Durham; (yellow ditto) and greenish ditto, with bevelled edges, from ditto

2744 A variety of petrefactions, as anomiæ, echini, casts of turbinated shells, fish teeth, in chalk

2745 A large mass of topazine fluor in cubes, with bevelled edges, Derbyshire

2746 Fine specinen of bubbled malachite, Siberia; iridescent bubbled copper, Cornwall ; blue malachite crystallized, Siberia, rare; and copper, Sweden - -0

2747 An elegant specimen of calcareous deposition, tinged of a delicate pink colour, from the cobalt mines of Hesse, very rare

$2748 \mathrm{~A}$ slab of avanturine, from Spain; and ditto of a greenish colour 
2749 An excellent specimen of crystallized sulphate of strontian, Bristol

2750 Three oriental mochas, ditto rose coloured, and a small specimen of the great Leverian chalcedony

2751 An Egyptian pebble, curiously variegated with veins and spots, and exhibiting in the centre the resemblance",of a pantaloon, or man wearing a fool's cap

2752. Native copper and malachite in stellated efflorescences, with vitreous copper, and white spar, Pokadeschky, Siberia ; native copper, Cornwall ; and two others - -

2753 Wood-like jaspar, and two elegantly figured agates, cut and polished

2754 A group of calcareous crystals, partly decomposed and coated with calamine,

2755 Sardonyx, East Indies; obsidian, Iceland; an agate chalcedony, with petrosilex, and another

2756 Complete, but small crystal of pale topaz, imbedded in quartz, Saxony; pitch stone, Siberia; and mica in quartz arragon, Spain

2757 A crystallized specimen of prase, rare, Germany

2758 Amethystine quartz of a very brialliant colour, in a fragment of a large siliceous nodule, Oberstein

2759 Foliaceous native copper, Siberia ; yellow copper, Sweden; and solid native copper, America

2760 A large and highly beautiful specimen of stalactitical chalce. dony, Ferrol

End of the Twenty-third Day's Sale. 


\title{
TWENTY-FOURTH DAY.
}

\author{
Saturday, the 31st of May, 1806.
}

\author{
2761 Parroquet, Brazils \\ 2762 Stannel hawk, and common wild duck, two cases \\ 2763 Larger spotted woodpecker \\ 2764 Pompadour-fronted parroquet, S. Seas \\ 2765 Blue grosbeak, America \\ 2766 Powter pigeon, cock \\ 2767 Superb warbler, male, New Holland; Silvia superla \\ 2768 Motacilla Australis. The southern motacilla, from ditto \\ 2769 Yellow-eared fly catcher, from ditto \\ 2770 New Holland thrush, Turdus nov. Hollandiae \\ 2771 Picus martius (Englich) rare \\ 2772 Brown warbler, New Holland; Motacilla pusilla \\ 2773 Violet tanager, Tanagra'violacea \\ 2774 Crested goastsucker, Caprimulgus cristatus, New Holland \\ 2775 Fuliginous petrel, Procellaria fulliginosa, from ditto \\ 2776 Pennantian parrot, fem. from ditto \\ 2777 Crested cockatoo, Psittacus cristatus, from ditto \\ 2778 Sacred kingsfisher, Alcedo sacra, from ditto \\ 2779 Knob-fronted bee-eater, from ditto, Merops corniculatus \\ 2780 New Holland creeper, Certhia nov. Hollandiæ, mas. \\ 2781 Ditto fem. \\ 2782 White fulica, Fulica alla, New Holland \\ 2783 Scythrops nova Hollandia, very rare, psittaceous hornbill \\ 2784 Red-legged partridge \\ 2785 Parrot, Brasils
}


2786 Black-headed creeper, Certhia spiza

2787 Red breasted flycatcher, New Holland

2688 White-vented crow, Corvus graculinus, very- rare, New Holland

2789 White hawk, Falco allus, from ditto

2790 Great hook-billed creeper, Certhia pacifica, m. and fem. Sandwich Island, very rare

2791 Black-faced baboon, rare

2792 Simia Atthiops, white eyelid monkey

2793 Little wild boar, Africa; Sus Africanus

2794 Lap dog and three kittens, remarkable for their similarity, two cases

2795 Virginian opossum, Didelphis Virginiana

2796 Fawn-coloured hare

2797 Pctto, S. America, Lemur potto

2798 Musk rat, N. America

2799 Marten

2800 Large black bear and cub, Ursus arctos

2801 Papilio Orion, papilio Midimus, Agamemnon, and six other butterflies

2802 Ten various species of libellula

2803 A great variety of small insects of the cimex, silpha, curculio, and other genera

2804 Silpha Americana, Surinamensis, and other coleopterous hymenopterous and dipterous insects

2805 Papilio Iris, Oryihia, Jo, Hyparete, and four more

2806 Curculio vittata, silpha vespillio, and fifteen others

2807 Cicindela sex maculata, carabus bimaculatus, curculio Germanica, silphæ, muscæ, \&c.

2808 Silpha thoracica, cicada frontalis, cimices, curculiones, \&c.

2809: Twenty-six insects of the vespa, sphex, chrysis, and other genera of hymenoptera

2810 Seventeen hymenopterous insects, chiefly apes

2811 Model of a canoe, Nootka Sound

2812 Dancing rattle, shaped like a bird, from ditto

2813 Curious dancer's mask, from ditto

2814 Bone truncheon, and a conical cap, from ditto

2815 Small feather cloak, and fly flap, Sandwich Islands

2816 Remarkably large spear, Nootka Sound

2817 Cloak, from ditto

2818 Feather necklace, and boars tusk bracelet, Sandwich Islands

2819 Elegant specimen of cut paper, framed and glazed

2820 Card curiously raised by a penknife, ditto

2821 Cap of mandarin, China

2822 Ladies shoes, from ditto

2823 Splendid head dress of a Chinese lady

2824 Chinese robe

2825 Silk hammock 
2826 Jasamine tube pipe, ornamented with amber, lapis lazuli, \&.c.

2827 Stockings made of legatto bark-

2828 Cap made of African grass

2829 Blue knit stocking, remarkable for its uncommonly fine texture

2830 Muslin shirt, (made in a loom) without a seam, E. Indies

2831 The long purple spot oyster, (Ostrea elongata, Soland.) Virginia-rare

2832 Chiton squamosus, W. Indies; the aculeated chiton, $S$. Seas; a stellated balanus, a scarce rhombus, and two others

2833 An Arabian spindle, and a Trajan's column needle-both large and fine

2834 Two varieties of the spider strombus, and a tulip cuma of a singular colour

2835 The green vulsella, exiremely scarce; and a striped margaritifera, both from the South Seas

- 2836 Pholas striatus Linn. in its native cell, formed in a piece of makogany; a chequered ear, New Zealand; the notched bull's eye breast snail, and a royal mantle pecten

2837 The box-wood cone, the huntsman cone, and a fern leaf triplex-all fine and rare

2838 A large black mother of pearl shell, Otaheite

2839 A warted hermit lobster, in a senectus pacificus, S. Seas, rare; a purple hermit lobster, in a magpie shell, W. Indies; and two rare snake shells

2840 A large and fine wentle trap, (Turbo scalaris, Linn.) Sumatra, very scarce

2441 A very large Triton's trumpet, with adhesions of oysters, Sicily

2842 Conus pulicareus, and the sanded cone; both large and fine; and the painted purpura, rare

2843 A large and fine purple spondylus, Sicily

2844 Two negroes' lips alatæ, a weasel alatus, two black musics Guinea; and a proteus olive

2845 The cocoa-nut fresh water snail, from Barbadoes, rare

2846 Several of the ostrea rhizophora, on part of a mangrove, W. Indies; pinna nigracans, $S$. Séas; and another species of the same genus

2847 The great brown melon, Guinea; and a ramose triplex, Madagascar

2848 The butterfly's wing, or Guinea Admiral cone, Guinea, rare

2849 Two fine camp olives, from Panama ; and a singular variety of the bat volute

2850 Two of the great thorny woodcock, from Arabia, very scarce; and a triplex scolopax, China 
2851 A very large ham pinna, Sicily

2852 A fine high Admiral cone (Conus Ammiralis, Linn.) having six lands, Amboyma, very scarce

2853 Impression of part of a large fossil pinna

2854 Cast of a pecten, Turin; valve of an arca, Piedmont; a pecten, ten various anomiæ, \& c.

2855 Twelve various fossil shells

2856 Part of a elephant's tusk, fossilised

2857 Impressions of shells in laminated limestone, masses of fossil shells, \&c.-_six specimens

2858 Eight various impressions of ferns, \&c.

2859 Curious fossil palate of a fish in chalk, part of an asterias ditto, a belemnite ditto

2860 A large and fine fossil grinder of an elephant

2861 Fragment of the fossil saw of a saw fish

2862 Two valves of fossil oysters, and sixteen various fossil anomiæ, some rare

2863 Two pieces of the rock of Gibraltar, parts of large vertebræ, and a single joint of another

2864 An echinus, and fragments of different spines of echini, in chalk-three specimens

2865 A curious striated pecten, an anomia of large size, and the valve of a Venus

$2866 \mathrm{An}$ oyster, with a curious impression, and a group of serpula

2867 Cast of a bivalve, having the surface eoated with marca-sites, an ostrea, and part of a rhombus, Hordwell Cliffs

2868 Six different impressions of plants, in stone, argillaceous iron, \&c.

2869 A large fossil arca, and a pecten ditto

2870 A cockscomb oyster, two valves of anomia craniolaris, Sweden; shark's tooth, in chalk, \&c. various

2871 Part of fossil grinder of an elephant fixed in a portion of the jaw

2872 Two teeth tinged and partly impregnated with biue oxide of copper, very curious

2873 Olive-coloured cubic fluor, in exquisitely well defined crystals, sprinkled whith minute marcasites, and having blend and calcareous spar attached, Derbyshire

2874 Native foliaceous gold, on ferruginous quartz, Hungary

2875 Two finely crystallized spathose irons, Germany; and native cinnabar, in white quartz, spain

2876 Part of a minute three-sided basaltic column, with olivin, Hesse; and steel-grained cohalt, from ditto

2877 Sixen specimens, agates, \&c. including potrstrect-peci-

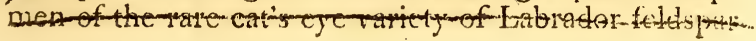


2878 A superb map-like variety of the iridescent feldspar, the prevailing colours of which are ultramarine and gold, possessing the pearly lustre in high perfection

2879 Native amalgam on white argil, Iüria; green copper ore, Germany; and red calcareous deposition, Hesse

2880 A fine mass of cobaltic ore, with pyrites, \&c. exhibiting the exact breadth of the stratum, Hesse, an interesting specimen

End of the Twenty-fourth Day's Sale. 


\title{
Catalogue
}

\author{
OF THE
}

\section{LEVERIAN MUSEUM,}

\section{PART IV.}

INCLUDING THE FOURTH EIGHT DAYS'SALE。

* * thl bemaining parts will be published with allo POSSIBLE SPEED.

THE SALE OF

\section{THE ENTIRE COLLECTION}

\author{
(By Messrs. KING and LOCHEE,)
}

\author{
WILL COMMENCE
}

On Monday, the 5th of May, 1806, at Twelve o'Clock, In the Building now occupied by

\section{THE MUSEUM.}

The five Parts of the Catalogue already published, (Price 4s. 6d.) to be had at the Museum; at Messrs. King and Lochée's, (the Auctioneers) and at Hayden's Printing-Office, Brydges-Street, Covent-Garden.

Hayden, Printer, 4, Brydges Street, Covent Garden. 


\section{CONDITIONS OF SALE.}

I. THE highest Bidder will be declared the Buyer; but if any Dispute should arise, the Lot must be put up again.

II. No Advance less than Sixpence; above One Pound, One Shilling; above Five Pounds, Five ShilLINGS.

III. Every Purchaser is to pay down Five Shillings in the Pound, as Earnest, in Part of Payment, and to give in his Name and Place of Abode, if required.

IV. The Lots to be removed, at the Expence of the Purchasers, within one Day after the Sale; and the Remainder of the Purchase-Money to be paid on or before the Delivery.

V. Upon Failure of complying with the above Conditions, the Money deposited in Part of Payment shall be forfeited. All Lots uncleared within the Time aforesaid, shall be re-sold, oy public or private Sale; and the Deficiency (if any) attending such Re-sale, shall be made good by the Defaulters a this Sale.

Gentlemen who cannot attend the Sale, may have their Commissions faithfully executed, by their humble Servants,

King and Lachée. 


\title{
TWENTY-FIFTH DAY.
}

\author{
Monday 2nd June, 1806.
}

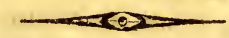

2881 WLEGANT feather-necklace, and two shell ditto, Sand-

2882 Bracelet, made of dog's teeth, and ditto, made of tortoishell, from ditto

2883 Drum, from ditto

2884 Small feather cloak, from ditto

2855 Beautiful fly-flap, from ditto

2886 A large piece of white quartz crystals, with a vein of blend crossing it, Alston Moor, Cumberland

29S7 A capital specimen of white rock salt of a botryoidal figure, Barcelona, Spain

2888 Basaltine adze, Sandwich Islands

2889 A capital group of yellow double pointed eighteen-sided spars, formed on the surface of limestone, Ashover, Derbyshire

2890 Leg-ornament, made of shells, and four bowls, (for playing with) made of polished stone,' \&c. Sandwich Islands

2891 A large specimen of opaque white quartz, sprinkled with plated marcasites, from a copper mine, Cornwall

2892 Pait of the trunk of a cork tree

2893 Ditto of the plane tree, very curious, E. Indies

2894 Vegetable lamb

2895 American whyeat of various colours, in a glazed frame

2896 Specimen of wood, grown in the form of a ring; and a singular nut, E. Indies 
2897 Locust pod, E. Indies; curious boat-shaped pod; and a curious large nut with a fibrous coat, E. Indies 4

2898 Curious seed vessel, Ceylon, commonly known by tho name of the Ceylon rose, It rotains the power of ex. panding like a flower, when immersed in water $/ 2$.

2899 Curious fungus, in a glazed case 2

2 goo Seed vessel of the sand box tree and specimens of West India cotton in the pod

2901 A fine specimen of the legatto tree, with its lace-like bark $6-6$

2302 A very fine specimen of the head of a palm tiee, Africa /

\section{MONKIES GROTESQUELY SET UP.}

2903 The Family Gardener $/ 3$

2904 The Bell-man

2905 The Coal carrier 7

2906 The Family taylor

14 The Beau, (simea sabea)

2908 The Ballad singers, (Sim. nyetitans)

2909 Simia Diana, two specımens $/ /$ - 6

2910 The Bald-face monkey, mahogany glazed case//

2911 Chinese bonnet monkey to

2912 A large piece of the rock of Gibraltar

2913 Two singularly impressed oyster shells, a mytilus, and four others

2914 Valve of a very large arca, Piedmont; a group of cockscomb oysters, and an ostrea gryphus

2915 Four pectens, various, and three ostreæ

2016 Forty various fossils, chiefly shells

2917 A large and fine whitish stalactite, from Eyam, Derbyshire 5

2918 A fine group of yellow calcareons spar, Matlock/s

2919 Fossil plants, in iron-stone, seven specimens

2920 Seven various fossils, chiefly shells, and casts of ditto

2921 A mass of many casts of small bivalve shells, having the surface saturated with pyrites; and a large ostrea

- 2922 Two vegetable impressions and part of a pebble, exhibiting a curious reticulated internal appearance $y$

2923 Fragment of a gigantic bone of some animal unknown

2924 Eight different impressions of vegetables in iron stone

2925 Two gigantic vertebral bones of unknown animals

2926 A studded arca, a pecten, several of the mytilus, and other genera

$2927 \mathrm{~A}$ winged pecten, a smooth pecten ${ }_{2}$ cast of another, $\mathrm{Mi}$ norca, and three more

2928 Cast of a large striated bivalve, and two other fossils

2929 Twenty-one various fossil shells 
2930 Six various shells, among which are a broad striated pecten, an arca with its cast, \&c.

2931 The oriental music, (Voluta elrcea, Linn.) and two fine orange-mouth olives

2932 The green sand mussel, (Patella unguis, Linn.) Amboyna; two varieties of the ram's horn sinail, (helix comu arietis, Linn.) W IIndies; and a small oblong trapezium, (Chama oblonga, Soland.) S. Seas-all rare

2933 Conus Proteus, $W$. Indlies; the groom cone, Madagascar;

2934 A small satchel pinna, (Pinna saccata, Linn.) China; the violet tray, (Solen violaceus, Soland.) Tranquebar; and a fine prince's mantle pecten, Friendly Isles-all rare $\gamma$

2935 An Oriental trumpet, a Pugilist's fist alatus, and a ramose triplex $11-1$

2936 Solen siliqua, or largest razor shcll, with the animalseveral specimens in spirits

2937 A large imperial sun, with a ridged pink serpula adhering, from New Zealand, very scarce

2938 Twelve specimens of marcisites

2939 The variegated spondylus, S. Seas; and a finely rayed variety of the bastard mother of pearl shell, China

2940 Buccinum dentex, Gallapagos Isles; conus magus, Nicolar Isles; and the huntsman cone-all rare

2941 A large bear's paw clamp, (Chama hippopus, Linn.) E. Indies

2942 A fine voluta nobilis, from China, very scarce

2943 The plow alatus, (Strombus gallus, Linn.) Martinique; the Proteus cone, very large, $W$. Indies; and a knobbed rhombus, China

2944 Two Hercules' clubs, in a young state, China; and a fine papal crown, Amboyna

2945 A fine cluster of quartz crystals of a reddish hue, with pearl spar, Bristol bo

2946 Piedra d' ynca marcasite from China, and eleven other marcasites

2947 A yellow chersina undulated with browns and a green and yellow reverse chersina, both rare

2948 Ccnus bullatus, the ermine's tail cone, and a lineated apiculum, all rare

2949 A large specimen of very deep coloured amethystine fuor, Derbyshire 2,6

2950 Strombus millepeda, Ceylon; two tulip cumæ, a small heavy turnep, and two alatæ

2951 White cubic fluor in small crystals, ditto in larger crystals of the same colour ; and purple cubic fluor, Derbyshire

2952 The morning dawn, or orange porcelain, (Cypraa Aurora Soland.) Friendly Isles, very rare 
2953 Beautiful group of purple fluor, with crystals of galena, the surface partially studded with minute quartz crystals, and brown pearl spar, Durham

2954 Opaque crystallised white quartz, and four others

2955 A large and fine group of purple fluor, Durham

$1-220$

2956 Eigh ght polished pebbles, chiefly English, and an onyx, Scotland

2957 Onachine rel and white carnelian, rare; six mochas, one agate. andatmifintony

$2 \mathrm{den}$

2958 A specimen of Spanish avanturine

2959 A noble specimen of purple cubic fluor, partly coated witl brown cauk, Derbyshire

2960 A curious striped pebble; an onyx, Scotland; and an agate ditto

2961 A rare Siberian carnelian, polished; spotted oriental jaspar, and two cut and polished sardonyxes

2962 Pyritical dendrites on slate, and dendritical manganese on white quartz, Hesse - both rare

2963 A delicately crystallised zeolite, Ferrol; and a quartz, the crystals containing iron

2964 Fasciculated calcareous spar beautifully coloured with copper, Germany, and a crytsallised calcareous spar

2965 Fine specimen of double refracting spar, Iceland; and bacon spar, Gloucestershire.

2066 Singular sparry deposition, Hesse; and a calcareous spar, Grece

2907 Delicate six-sided spar, Cumberland $p-4,-0$

2968 Needle-antimony, Hungary; mispickel; and plumbago, Cumberland

$2909 \Lambda$ singular serrated, or saw-like spar, Oxfordshire 4

2970 Three large beautiful bead agates, and two agates, polished the

2971 White shorl, stalactitical calcedony, opal in the matrix, Saxony; and an onachine pebble dug up in Leadenhall. street $/ 5 \%$

2972 Fasciculated calcareous spar, dark coloured rhomboidal spar, and a group of stalagmitical spar.

2973 A large and fine crystal of adularia, having smaller crystals attached, Switzerland

2974 Quartz, with calcareous spar in short hexagonal columns, with tribadral pyramids

2975 Calcareous spar in hexajonal crystals, with triæhdral pyra: mids : and calcareous spar in indeterminate crystals, with a singular metallic gloss

$297^{6}$ Part of a curious septarium of brown sand stone, having the insterstices filled with white calcareous spar

2977 An Oriental mocha, of large size and very fine; ditto, Germany ; brown crystal seal, and a beautiful small red carnelian $y=2 \cdot 0$ 
2978 A fine group of quartz crystals, Cornwall

2979 A very large mass of complely fossillised wood (English)

2980 Two Scotch agate pebbles, and three agates, cut and polished //

2991 Pitch stone, Siberia ; jaspar ; quartz, Bristol; and an onachine agate

$2982 A$ model in glass of the great Brazilian diamond, in the royal cabinet at Lisbon, weighing 1680 carats, and valued at 224 millions sterling, vide Cronstedt $172-t$

2983 Brown octohædral tungsten, Zinnwald, Bohemia - 144

2984 Dark coloured spar of six sides, from Monte Marte; and a stalactitical group of small nummular twelve sided spar

2985 Thirty-sided calcareous spar, and hearh-like spar, of a white colour $/ 0$

2986 Plumose argentiferous antimony, on crystallized quartz, Hungary

2987 Nummular twelve-sided spar, Cumberland

2988 Dog"s tooth spar, with elastie bitumen, Derbyshire 2

2989 A curious ramose calcerous spar, Cumberland

2990 Beautiful calcareous spar, in groups of pointed crystals, Germany $1-m$

2991 Lenticular spar in large crystals, upon quartz $1-15 \times$

2992 Black oxyde of cobalt Hesse, very rare

2993 Carbonate of :ranium, finely crystallized, Saxony

2994 Solid lump of native gold, Wicklow, Ireland

2995 Lenticular spar in the hollow of a nodule, and clear twelve-sided spar on blend, Cumberland

2996 A large and fine group of brown stalagmitical spar, with a rough or cauliflower like surface, Matlock, Bath -.

2997 Two specimens of blend, Cumberland; one of them coated on the side, with pearl spar $2.73 \cdot 0$

2998 Grey gold crystallized, with rose coloured manganese, Transylvania $10-6$

2999 Auriferous pyrites in quartz, ditto crystallized, foliaceous native gold, Hungary; and grey gold in white manga. nese, Transylvania

3000 A fine group of rhomboidal selenites, from Whitchurch, Cheshire

End of the Twenty-fifth Day's Sale. 


\title{
TWENTY-SIXTH DAY.
}

\author{
Tuesday, the 3rd of June, 1806.
}

$3001 \mathbb{P U D D I N G}$ Stone, a large specimen, Herefordshire; ferruginous quartz, Bristol; and two other specimens of quartz ito $=6$

3002 Actynolite, Cornwall; prehnite, Scotland; hornblende in quartz, and another "

3003 A rich mass of crystallised topazes in the matrix, Siberia, very rare

3004 A very fine stellated sattin-like malachite, Siberia; yellow copper, Sweden; and another $/$

3005 Two large garnets, and a group in the matrix, Aberdeenshire; and a dark coloured quartz, Bristol

sov6 Iron and manganese, a very fine specimen, Triers

3007 Obsidian, Scotland; garnets in mica, ditto; quartz, with a rugose surface; and two more

3008 Amethystine quartz, ferruginous ditto, Bristol; mill stone, petrosilex, France; red spotted pitch stone, uncommonly rare, Siberia; and two more

3009 A large and clear specimen of crystallised quartz

3010 A large Erglish pebble, polished; black-veined jaspar, and almond stone, inclosing agates, Scotland

3011 Five specimens of quartz, one an opaque quartz, having crystallised transparent quartz on the surface, and eight smaller specimens of minerals

3012 Zeolite, three kinds, one on amethystine quartz; a garnet crystal, Scotland; and two more minerals 
3013 Quartz crystals, Cornwall; quaytz, with galena; and quartz on flint, Sussex

3014 Double-pointed rock crystal, $n$ cauk, Somerset; blend, on quartz, aud quartzecrystal

3015 A very large and fine specime fof crystallised quartz, with galena, Cumberland

3016 A grand specimen of mammillated orange-coloured pearl

5 - spar, with groups of gaiena, on the surface, Cumberland 3017 Agates, four specimens, two onyxes, and three pebbles 3018 Specimen of green stellated sattin-like malachite, yellow copper, with greenish actynolite, Sweden; and dingy quartz, with moss-like native copper, from Uralgeburge, Siberia $30-6$

3019 Dendritæ, on yellow laminated marble, from Papenheim

3020 White quartz crystals, with jet black points, calcareous spar, zeulite, calcedony, and two more 4 .

3021 A fine specimen of capillary bismuth, Germany

3022 An xtites containing two kernels, ditto small, with one kernel, and a third ætites broken asunder

3023 Three varieties of arseniate of copper, a malachites copper, octohædnt fluor, and crystallized tin, all from Cornwall

3024 An elegant specimen of verditer blue arseniate of copper, Cornwall; and a slab of lumachelii, Bleyberg 2

3025 Fortification cobalt, Hesse; and two other cobalts, and gypsum, Germany

$3026 \mathrm{~A}$ rich specimen of the map-like variety of iridescent labrador feidspar, the variegations of which are regal purple edged with gold and blue $/$ an

3027 Two silver ores, one from Siberia, one chalcedony, Cornwall; and another

3028 Cubic fluors of an amethystine colour variegated with white, Durham,$-6-\infty$

3029 A fine specimen of arborescent copper nickel, with arseniate of cobalt in barytes, Hesse

3030 Marcasites of fourteen sides, Sheppy Island ; and marcasites, on calcareous spar, and argillaceous stone, Monmouthshire

3031 A large nautilus pompilius, uncoated and engraved, and having some of its celis displayed

3032 A large 'shagreened trochus, Clina; senectus phasianus, S. Seas; and the ribband snake, Amloyna, all fine //

3033 A very young ostrea gigas, Friendly Isles; a scarce purple gryphus, New S. Wales; and a swallow margaritifera, Pulo Condore

3034 The orange-striped helmet, a young bull's mouth helmet, a devil murex, and a dolphin snail 5 
3035 A granulated cochlus, two white suns; a scaree senectus, two pied inulberries, and three more $>-4$

3036 The great swamp club, China; and abishop's mitre, uncommonly large, Madagascar. - -

3037 A variety of terrestial and aquatic shells, natives of the British Isles

3038 The granulated turbo, Nootka Sound; conus notabilis, China; and the painted cone, Cape of Good Hope-all rare

3039 A large and fine thorny snipe, (Murex brandaris, Linn.) an urn melon, distorted by accident, and a small spotted melon

3040 Cidaris abreviata, St. Mauritius; another oval turban echinus, from the same Island; and a cordated echinus from the $W$. Indies, all rare

3041 A very large triadachna elongata, or long furbelowed clamp, Madagascar

3042 The green-beaded rosaria, a ballustrade trochulus; a rare cassidula, two Prince of Orange's flag chersinx, two scarce rhombi, and an alatus os

3043 The great flat-spired strombus, China

3044 The purple-mouth frog, two pheasant snakes, a yellow fig, two mulberries, a horse chesnut, and two chersinze

3045 Two very large cockles, viz. cardium robustum, from Florida; and cardium spinosum, from Sicily, both raire 4 .

3046 The spider's-web cone, Nicolar Isles, very rare; a scarce variety of the zebra trochus, and a fine brunette cone

3047 A diadem echinus, W. Indies; another echinus, from the same country; and an oval turban echinus, E. Indies

3048 The orange-coloured variety of the Nereid's trumpet, W. Indies, scarce 5 : 6

3049 A large and fine oriental music (voluta elrcea, Linn.) from Ccylon, rare $=1$

3050 An extremely scarce variety of the swallow margaritifera, (Mytilus hirundo, var, China; and the white vulsella, rare, S. Seas

B051. Crow, with curiously distorted beak

3052 Green parrot, S. America $4=$

3053. Cuckow, young; and common magpie

3054 Icteric oriole, oriolus icterus

3055 Bramble finch, and canary bird, m. and fem. 6.

3056 Certhia olivacea, Sandwich Islands, yery rare -6

3057 Small turtle dove, E. Indies

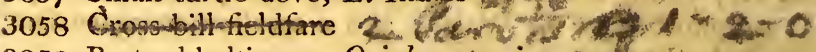

3059 Bastard baltimore, Oriolus spurius

3060 A case containing six specimens of the African sung birde

3061 Grass-hopper lark, mas. 5 , 5. " ?

3062 Light-coloured variety of the grous 3

3063 Dominican grossbeak, Inxia Dominicana 
3064 Wheat ear, and land rail, young

3065 Purple-fronted grossbeak, $m$. and fem

3066 Rain cuckow, cuculus vetula

3067. Crested grakle, gracula cristatella

$306 s$ Partridge variety

3069 Spectacle owl, strix perspicillata

3070 Certhia vestiaria, very rare, $m$. and fem. Sandwich Islands

3071 Part of a very large pecten, and bones in spar, from $\mathrm{Gi}$ braltar

3072 Cast of a chama, allied to the species cor, and an oyster shell

3073 A recent astragalus, and another presumed to be fossillised, Shotover

3074 A very singular fossil double tooth, and a vertebral joint imbedded in stone, from Stonsfield

3075 Piece of a fossil bone, vertebral bones of fishes, teeth; \& 8 . seven specimens

3076 Eight various joints of fish bones, \&c.

3077 Two fossil bones, one supposed to be of a large marine animal

3079 Part of the great rhombus, Hordwell; casts of the branches of encrini, \&c.

3079 A studded arca, a striated mytilus, and a pecten

3080 Fourteen various anomix, \&c. an ostrea, and cast of a chama

3081 Vertebral joint, in free stone, fiom Stonsfield; another from Shotover, and a fragment of bones, in spar, Gibraltar

3082 Three oysters with various impressions

3083 A vertebral joint, with part of the rib attatched, and another joint of a vertebra

3284 Fragment of a singularly contorted horn, similar to that of the monodon monoceros

3085 Cast of a very large shell of the chama tribe

3086 A group of small fossil pectens, and a large oyster

3087 Two vertebral joints, and a large mass with vertebral joints, and the gryphites oyster

3088 Twenty-two various species of anomia, \&c.

3089 Sabella penicillus, with the animal, an 1 a fucus, two bottles

3090 Rana pipra, the Surinam toad, with a number of the young adhering to the cavities of the back

3091 Atherina japonica, an hippocanæus, and syngnathus, or pipe fish, in three bottles

3092 Iarva of bombyx imperialis, another of a cossus, a singulay spinous larva of a moth, and a spider-four bottles

309.3 Scolopendra morsitan's, et sepia, and a curious labrus 
3094 A bottle, with several tarantulæ, and two larvæ, one of a lepidopterous, and the other of a coleopterous insect, in two bottles

3095 Large cubical fragment of rock salt, Barcelona, and part of an argillaceous nodule

3096 Curious calcareous spar, with galena; and barytes, with decomposed calcareous spar, Cumberland

3097 A fine group of yellow cubic fluors, Derbyshire

3098 Large specimen of white quartz crystals, some of them double pointed, Bristol

3099 Mammillated iron ore, 'Triers; iron ore, with silvery mica; stalactitic iron, Triers; and spathose iron 2

3100 Fibrous calcareous spar, and another delicately crystallised calcareous spar, on quartz

3101 Papilio Orion, Midamus, Chrysippe, Agamemnon, and four other species

3102 A great variety of insects of the locust, myrmeleon, and other tribes

3103 Nine libellulæ

3104 Several species of silpha as Surinamensis, Americana, Germanica, \&c. and seventeen other insects

3105 A large specimen of Obsidian, Iceland

$3106 \mathrm{~A}$ fine and large specimen of the oxyde of cobalt, Scotland

3107 A group of white quartz crystals, on fluor, with galena, Derbyshire zim

3108 An elegant specimen of purplish chalcedony, being a portion of the specimen, lot $1560 / / 4$, the

3109 Dog-tooth spar of a chocolate colour, in a ferruginous nodule

3110 A very noble specimen of black stalactitic iron ore, with the surface somewhat iridescent, on a basis of hacked quartz, Triers

3111 A capital crystal of dog's tooth spar, Derbyshire $f * b$

3112 A very fine polished slab of Florentine marble, in a frame

3113 Calcareous spar, in hexagonal columns, with three-sided pyramids, on galena, Derbyshire

3114 Lenticular spars, two fine specimens

3115 Calcareous sand stone, in rhombs, Fontainbleau

3116 A capital group of tabular barytes, sprinkled with calcareous spar, Westmorland

3117 Two elegant drawings of agates, by Miss Stone, framed and glazed of 0

3118 Imitations of mochas, and small landscapes, chiefly produced by minute sea-weed, elegantly framed and glazed

3119 An eminently fine group of clear quartz crystals, some of them intersecting each other, Dauphing

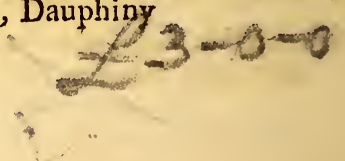


Y 3120 A singularly large and beautiful slab of oriental mocha, cut and polished, richly diversified with dendritæ or ferruginous arborescencies. N. B, The appearance of this specimen is uncommonly fine when held against the light $3-8-6$

End of the Twenty-sixth Day's Sale. 


\title{
TWENTY-SEVENTH DAY.
}

\author{
Thursdiay; 5th June, 1806.
}

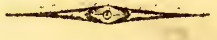

3121 LESSER speckled loon

3122 Bohemian chatterer

3123 Sparrow variety, having fourteen claws

3124 Oxeye titmouse, and robin, $m$. and fem.

3125 Short tailed crow, Corvus brachyurus, rare

3126 Little auk; Alea alle

3127 Carrier pigeon, $m$. and fem.

3128 Scarlet and green lory, E. Indies

3129 Water hen, $\mathrm{m}$. and fem.

3130 Wall-creeper, Certhia muraria, rare $2-6$

3131 Cinnamon dove, Jamaica

3132 Whinchatterer, m. and fem. and yellow wagtail, three specimens-two cases $/ 2$

3133 Canary bird, Cape of Good Hope, m. and fem.

3134 Tanagra violacea, m. and fem. Surinam

3135 Peregrine falcon

3136 Black-headed butcher bird

3137 Psittacus Alexandri

3138 Gray plover; m. and ferm.

3139 Cetthia spiza

3140 Crax Alector, bred at Osterly Park

3141 A case, containing three young barn owls

3142 White variety of the starling

3143 Caprimulgus maximus, remarkably large and fine

3144 Rose-coloured spoon bill, Platalea rosea, very rare 
3145 Curious basket, New Amsterdam 3

3146 Large specimen of matting, from ditto

3147 Ditto of Otaheite cloth

3148 Curious ornamental large gorget made of feathers, mother of pearl, shark's teeth, \&c,-Marquesas

3149 Cordage, fish-skin file, fish hook, ditto decoy, a comb, and tattooing instrument-Otaheite 10

$3150 \mathrm{Knife}$-shaped instrument, made of dark green nephiritic stone, New Zealand

3151 Fly-flap, with a curious ornamented handle. This belonged to Powlohow king of Tongataboo

3152 Remarkably large fish hook, New Amsterdam

3153 Crystallized baroselenite, Hungary ; black mica, Scotland; crystallized mica, Bohemia ; Bologna stone, Cauk, and three others

3154 Cubic fluor of a light colour, with marcasites on the surface; and marcasites with mammillated cank, on fluor

8155 A fine specimen of ruby copper; ditto of vitriolic bluxe arseniate of ditto, and a crystallized tin, Cornwall $.7=$

3156 Richly ornamented Persian shoes

3157 Mogul half boots

3158 Mandarin boots, China 2

3159 Chinese lady's shoes, remarkably small

3160 Elegant Bengal slippers

3161 Opake columnar spar of twelve sides, on a group of white quartz, Cumberland 6

3162 Delicate Chinese painting on glass, of a lady with a bird on her hand $6-2$

3163 Small Chinese compass, and ditto swampari

3164 A large and most elegant fly-flap, entirely formed of finely worked ivory, an article of great leauty $2-12$

3165 Heath-like spars, Gloncester; and a grotip of quarfe on galena, with calcareous spar

3166 A capital group of amethystine fuor, in large cubic crystals,

y Durham $y-y=2$ :

\$167 Two curious calcareous spars

3168 Two specimens of pudding stone, and agates in the matrix

3169 Delicate six-sided spar, Cumberland; and two other calcareous spars

3170 Golden mica, in quartz; barytes, crystallized; and sulphate of strontian, Bristol

3171 'Two dog-tooth spars'

3172 A fine and large ocellated pebble, Scotland

3173 Ribband jaspar, a fine and lạrge śpecimen, Siberia

3174 Purplish bubbled calcedony, an elegant groun of minute yellow quartz crystals, and a group of rock crystals, Cornwall

$2175 \mathrm{~A}$ beautiful and singular specimen of iridescemt labrador 
feldspar, richly, variegated with orange, purple, and blue

3176 Greenish cubic fluors, with bevelled edges, some of the cubes frosted with spar, Derbyshire

3177 A very noble specimen of pure rock crystal, containing a profusion of delicate green hair-like crystals of actinolite. An article of great beauty

3178 Rich brown dendrites, on laminated sand-stone, Lancashire

3579 Two specimens of pudding stone, Hertfordshire; and a third from Scotland

3180 Rhomboidal brown spathose iron ore, Gloucestershire ; spathose iron ore; micaceous iron ore, Lancashire; and black spathose iron ore, with calcareous spar

3181 Brilliant marcasites in small cubes, coating the surface of calcareous spar, Ecton, Staffordshire

3182 A pair of small obelisks, made of Derbyshire fluor

3183 A pair of elegant vases of ditto

3184 A pair of extremely hardsome columns, chiefly made of ditto

3185 Papilio populi, Apollo, Iris, and five other species

3186 Eleven libellulæ, two of panorpa coa, and three others

3187 Twenty-three various hymenopterous insects, chiefly apes

3188 Sixteen cimices, silphæ, and other insects

3189 A variety of the sphex, vespa, chrysis, and other hymenopterous genera-in all twenty-four specimens

3190 Tw enty-fonr coleopterous insects, chiefly scarabæi

3191 Meloe cichorei, silpha Americana, and various other silphæ, yespa, \&c.

3192 Buprestis ocellata, elater ocellata, cicindelæe, several of the dytiscus genus, \&c.

3193 Twenty hemipterous insects, including cicada atrata, nepa. grandis, (a pair,) with a number of cimices $y$

3194 Raphidia maxillosa, a myrmeleon, and a libellula

3195 The banded oak wood cone, rare; the rose bush triplex, and a brocade cone

3196 A scarce oriental olive, two other olives, and three more

3197 Two ferruginous, and two leopard needles, and a scarce bellied distaff shell-all fine $\neq 2$

3198 A polished wax taper cone, and two of the tapestry wave, Madagascar

3199 A very scavce melon, called the Japanese crown, Japan

3200 The striated and chequered figs, a large beauty limpet, and three porcellanxe

3201 A large Argonauta nodosa, Soland: or tuberculated paper sailor, Brazil-rare

3202 The great helmet, $W$. Indies; and a cornuted belmet, China: 
3203 Two echinated suns, a scarce staircase, the tyger trochellus, the icy mulberry, a scarce variety of the Holland flag chersina, and three others

3204 Conus nebulosus, $W$. Indies; a fine conus monachus, $M a$ dagascar; and the painted scoop; from the Gallapagos Islands-all rare

3205 Fourteen various petrifactions, chiefly shells

3206 A vertebral joint, having one end cut and polished, and a vertebral joint imbedded in stone, Stonsfield

3207 A rare winged fossil strombus, France; and a variety of other shells, some scarce

3208 A very large pecten, Bath

3209 Part of the lower valve of a pecten imbedded in stone, and one valve of a striated arca

3210 Cast of a trochus, a chama, an ostrea, cast of an arca, and a nautilus

3211 Vertebral, and other bones of animals, one of a fish

3212 An ostrea of gigantic size, Bath

3213 Ostrea gryphites, several of the anomia genus, a pecter?, \&x. - in all ten specimens $2 .-2$

3214 A large fossil oyster, and a nautilus

3215 Casts of several chambers of the orthoceratites, an echinus in flint, part of the Hordwell Cliff rhombus, \&c.-fifteen specimens 7 - -2

3216 Five impressions of ferns, and their counterparts

3217 Eight vegetable impressions in argillaceous iron, and another on coal slate

3218 Nine fossils, various, among which are two of the belemnite, and a striated mytilus, Bath

3219 Mass of entrochi, ditto of marine remains, Dudley; and and two more, with the Hordwell rhombus 3-6

3220 Fossil tooth imbedded in stone, part of an elephant's grinder, and vertebral joints, \&c.

3221 Impression of a studded arca, an anomia, pecten, 8 c. 2.6

3222 A large fossil vertebral joint of some unknown animal

3223 Seven small nodules of argillaceous iron containing vegetable impressions

3224 Casts of pectens, and sundry other bivalves, \&c.-eleven specimens $1-6$

3225 Cockscomb oyster, a studded arca, striated pecten, \&c.twelve specimens

3226 Ten various impressions of pectens, \&c. 3

3227 Cast of a sulcated chama, and a large oyster

3228 Three sections of ammonites, an echinus, and pecten

3229 Eight various fossil shells, chiefly pectens

3230 A large and fine slender distaff shell, Murex colus, Linn. China-rare $(-1-0$

3231 Two beautiful Asiatic olives, and the hare alatus - rure 
3232 Two brown caterpillar clubs, a white caterpillar, a large gray beaded club, a small bishop's mitre, and the false ditto-all fine

3233 The onyx lamp, $W$. Indies ; a purple variety of helix variegata, China, and another rare land snail

$3234 \mathrm{~A}$ very large and fine high spired turnep, having its epidermis, Madiagascar

3235 A rare mammillated diadem echinus, and another with its spines-both from $S t$. Mauritius and rare

3236 Two large banded apple snails, of different species, one of - 6 them from Bengal, rare; and a fine basket clam, China

3237 The black hammer margaritifera, with curious adhesions of gryphi, Ec. Pulo Condore-rare

3238. The beaded mitre (Voluta scabriuscula, Linn.) from China : and two of the lineated mitre, from the Friendly Islands -both species rare

3239 A rare echinus of the clypeated kind, from the South Seas, very scarce

3240 A very large fresh water shell of the barbala genus (Mytilus illita, Soland.) Brasil, very scarce

End of the Twenty-seventh Day's Sale. 


\title{
TWENTY-EIGHTH DAY:
}

\author{
Fridaly, the 6 th of June, 1806.
}

$3241 \mathbb{R}$ ANA pipiens, the peeping frog, two other frogs, and another

3242 A small diodon, two of the blennius genus, and three others

3243 Two singular snakes, and two insects of the locust tribe in the pupa state

3244 Scolopendra morsitans, and a beautiful blue snake, c. cæerulea

3245 A small raja torpedo, a rana, common whelk, and a fishfour specimens

3246 An elegant specimen of testudo mydas, or common green turtle, of a small size

3247 Lacerta salamandra, (the true salamander) blennius gunnellus, and a curious snake

3248 Large and curious larva of a moth, Surinam; ditto of an exotic sphinx, and two fishes, one the spotted weaver

3249 Lacerta monitor, and another singular lizard

3250 Variegated lizard, Lacerta varia. New Holland

3251 Rana crerulea, blue frog, from ditto

3252 The striped lizard, speckled ditto, and two more lizards

3253 Lacerta seps, another lizard, and a fish

3254 A large snake

3255 Scincoid lizard, Lacerta Scincoides, New Holland 
3256 The Persian robe cuma, E. Indies; the pyramid trochus, New Caledonia; and a bull's mouth helmet

32.57 'The black mother of pearl shell, Sandwich Isles, fine

3258 A scarce variety of the argus frog, S. Seas; the yellowmouth endive, and another scarce oriental triplex

3259 Two of the rheda bullara, or bellied Venus' chariot, Mediterranean; three of the licium genus, a scarce physiter, two mosaic dactyli, and four others

3260 The great flat-spired spider, in a young state; a spotted tuin, two large serpulæ, a scarce triplex, and an Alexandrian purpura

3261 A fine orange mouth ear-like terrestial shell, (Voluta elongatu, Soland.) New Caledonia, very rare

3262 A large rhombus lacerta, or lizard rhomb, China

3263 Two large telesscope clubs, from Tranquebar; and a very singular variety of the Trajan's column needle

3264 The leopard, the panther, and two ferruginous needles, from Madagascar, and a young Arabian spindle

3265 Two varieties of conus aulicus, and a large necklace scoop -all fine and rare

3266 A fine variegated spondylus, S. Seas

3267 An orange coloured uber, Haynam; two white breast snails, S. Seas; a scarce nerita, Isle of Cocoas; a pied variety of the painted nerita, and a fibrous balanus

3268 The Ethiopian crown melon, Molucca Isles, rare

2269 A zebra trochus, partly uncoated, the leopard cone, and the flag cone-all fine

3270 The great alatus, or winged shell of the W. Indies, with a leautiful pink mouth

3271 Thi warted hermit crab, in a senectus pacificus, from the $S$. Seas; a group of balanus striatus; and an English oyster with adhesions of serpula lumbricalis

3272 A large weasel cone, Madngascar; the gray lineated cone, China; and a large purple mouth frog, s. Seas-all fine and rare

3273 The violet ringed and star'd echinus, from China, very rare

3274 A large conus flammeus, Amloyna ; the staircase of ex. traordinary size, Tranquebar; and the great spectre cone

3275 The great high Ailmiral cone, Friendly Islands, very rare

3276 The rayed carrier, from China, extremely scaice.

3277 Red shouldered parroquet $/ 8-6$

3279 House marten, m. and fem. and young swift

3279 Golden oriole, Oriolus galbula

3280 White variety of the robin

3231 Butcher bird

3282 Large brown water hen, South Seas, rare

3283 Lesser black and white woodpecker, (m. and fem.) and 13 
yellow wagtail-two cases

3284 Sparrow haw

3285 Black bird variety

3286 Titmouse of Paradise $1-12-0$

3287 Ouzel, m. and fem.

3288 sivia superlia, New Holland

3280 Scarlet and purple lory $\mathrm{E}$.

3290 Common boopoe 3291 Sandpiper, and four of the young 18

3292 Blue-backed manakin, m. and fem. Pipra pareola, rare $/-1 b 7$

3293 Yellow headed parrot, Brazils

3294 Certhia spiza

3295 Turdus Orpheus, mocking thrush

3296 Piperine toucan, Ramphastos piperivorus $1-2 \cdot$

3297 Close frock, made of leather, ornamented with tassels, and narrow thongs, from Cook's river

3298 Foul weather frock, ingeniously formed of whale's intestines. The seams are so contrived as to exclude water, from ditto

3299 Hood, made of very fine squirrel's skin, from ditto

3300 A polished slab of Derbyshire fluor, with internal marcasites forming veins on the surface, and a large group of stalactitical marcasites

3301 Truncheon of bone, and a conical cap, from Nootka Sound

3302 Curious cuat of mail, made of wood, from ditto

3303 Petticoat of curions manufacture, one side being matting, the other so wrought as to resemble shag-Friendly Islands

3304 Mantle, from Nootka Sound, made of the skin of some animal, ornamented with rows of dried hoofs, \&c.

3805 Model of an Esquimaux canoe

3306 Millepora carulea, tubipora musica, and isis ochracea

3307 An elegant specirnen of madrepora Damicornis, E. Indies

3308 A ditto of madrepora annularis, W. Indies

3309 A ditto of madrepora reticulata, rare, from the $\mathrm{E}$. Indies

3310 A very large specinen of millepora alcicornis

3311 A partially compressed specimen of madrepora fungites

3312 Madrepora seriata of Pallas; delicate white branched coral, having the cells of the animals placed in straight row's

3313 An elegant specimen of gorgonia pretiosa on its native basis, Sicily

3314 Madrepora talpa, mole-like coral, from the coast of New South Wales

3315 A brainstone madrepore of uncommon magnitude

3216 Seven bivalve fossil shells

3317 'Two oysters and the cast of a large bivalve of the Venus kind

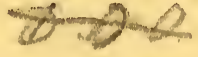


3318 Fossil coralloid, corals with pholades, and two more

3319 Six various species of ammonites

3320 Three fossil coralloids, one a curious cast from Maestricht

3321 Impression of a fish in limestone, from Oxfordshire

3321 Cast of a sulcated anomia, and a large oyster

3322 Five small nodules of argillaceous iron, with impressions of ferns, and their counterparts

3323 Sections of ammonites, \&c. nine specimens

3324 Two sections of a fossil nautilus, and a cast of an ammonite, with spar and marcasites

3325 Three fossil coralloids, one a very curious mass with various impressions

3326 Two singular teeth (with part of the jaw attached) of some unknown animal of considerable size

3327 A variety of fossil shells, chiefly bivalves

3328 Sparry incrustation, and two kinds of oyster

3329 Six various specimens of fossil nautili, ammonitæ, \&c. $/ 4-6$

3330 Thiee fragments of the cast of a large oyster-shell, and a mass of bivalve shells

3331 Three coralloids, madrepore, \&z.

3332 Nine various fossils, chiefly sections of ammonites

3333 Various parts of fossil nautili, and a series of the vertebral joints of a fish in indurated marl

3334 A fine and curious specimen, including part of the head. and back bone of a small kind of lacerta imbedded in grey limestone, Gloucestershire-a large slab cut and polished

3335 Two casts of ammonites, two sections of ditto, and two more

3336 A very large specimen of an ammonite

3337 Singular cast of a fossil madrepore, Maestricht, very. curious, and another

$3338 \mathrm{~A}$ slab of black slate with numerous impressions of a double eared pecten

3339 Cockscomb and lenticular marcasites, with small cubic fluors, having bevelled edges

3340 Large and fine specimen of shorlite, Altenberg; delicate white and yellow chalcedony, Cornwall ; and blue compact copper ore, Hesse

3341 Octohædral fibrous antimoniated lead ore, Leicestershire; crystallized gray copper, Cornwall ; and crystallized tin with pink mica, ditto

3342 Barytes, in well-defined tabular crystals, a fine specimen, Cumberland

3343 A hollow ferruginous nodule, lined with spar and quartz; rock crystal, Bristol; and quartz on white chert

3344 Fine specimen of grayish cubic fluor, with bevelled edges, 
partially coated with calcareous crystals, dark amethystine cubic fluor, Derbyshire

3345 Ruby copper, Cornwall; arseniate of iron, ditto; and octohæhral fluor, ditto

3346 Two elegant varieties of green and blue arseniate of copper; and two crystallized tins, Cornwail is - 6

3347 Four elegant varieties of arsenical copper, Cornwall - -

3348 Three varieties of arsenical copper, and a Jarge specimen of octohæciral fluor, Cornwall

3349 Topazine cubic fluor, with blend, Derbyshire; fine and large cubic violet fluor sprinkled with minute quartz crystals, and small crystals of lenticular spar, Durham

3350 A small three-sided column of basalt, and a specimen of nodular basalt, Hesse $2-2$

3351 A large group of marcasites in minute crystals, Ecton, Staffordshire ; and cubic fluor, having the surface partially coated with marcasites, Cumberland

3352 Two specimens of steatite, one from Derbyshire, the other from Googrease mine, Cornwall

3353 Nine various specimens of volcanic matter, from the : Island of Ascension

3354 A large group of crystals of gypsum, and a large flat crystal, from Oxfordshire

3355 A small specimen of iridescent labrador feldspar, of singular beauty and diversity of colours

3356 Gray gold crystallized in rose-coloured manganese; and native gold with calcareous spar, Kapnic

3357 Large and fine specimen of arseniate of iron, blistered cop. per, and cavernous quartz-all from Cornwall

3358 Capillary bismuth, Germany; and horn-blend with mica, Sic.

3359 Four varieties of arseniate of copper. Cornwall

3360 An elegant specimen of avanturine, Spain

End of the Twenty-eighth Day's Sale. 


\section{TWENTY-NINTH DAY.}

Saturday, the 7th of June, 1806.

3361 JARGE American war weapon

3362 Ditto of a different construction

3363 Singular American leather pouch

3364 Ornamented Canada shoes

3365 Chinese ditto

3366 Ancient English ditto

3367 Stocking, made of the silky beard of the large Mediterranean mussel

3368 Green nephritic stone idol, Otaheite

3369 Complete fur dress, Hudson's Bay

3370 Elegant bead pouch, made by North American Indians

3371 Chinese robe

3372 Jasamine tube pipe, ornamented with amber, lapis lazuli, \&x.

3373 Brasilian feather cap

3374 Chinese scales, and instrument case of a Chinese barber

3375 The Chinese emblematical figure of nature, curiously carved in pink nephritic stone

3376 Specimen of an elephant's tusk, inclosing a leaden ball

3377 Chinese organ

3378 Chinese mariners compass, and ditto Cooper's compass

3379 Elegant white nephritic stone bracelet of a Chinese lady

3380 Elegant dress of a young lady of Tripoli

3381 Avadavad, three specimens

3382 White variety of the wagtail

3.383 Sky-lark variety 
3384 Puftin, Isle of Wight

3385 Striated olive woodpecker, America, Picus striatus

3386 Ring parroquet, Psittacus Alexandri

3.387 Black and yellow finch, m. and fem. Africa

3388 Triangular spotted pigeon

3389 White-tailed humming bird, Trocliilus leucurus

3390 Fan-tailed wren, $m$. and fem.

3391 Gane cock, finely preserved

3.392 Gold pheasant, m. fem. and two young, Phasianus pictios

3393 Open footed duck, Anas boschas

3394 White varicty of swallow

3395 Goosander, and young woodcock-two cases

3396 Blue gross-beak, S. America, Loxia carulea, var. B. cyanea

3397 Garganey duck, male, Anas querquedula

3398 Whinchatter, $n$ and fem.

3399 Shining thrush, Angola, Turdus nitens, var. A.

3400 Great billed tody, Todus nasutus, extremely rare

3101 The painted clam from China; a fine donax scortum, Linn. from Tranquebar; the chequered fig, and three porcellanæ:

3402 A parcel of damaged echini, some rare

3103 A mammillated echinus, Arabia; and two other diadem echini-both having their spines

3404 The violet ringed and starred echinus, China, very rare

3405 Two panther porcellanæ, two of the shield clam, one of them polished, the wrinkled ear, a young zebra alatus, and three others

3406 Three various pinnæ, two groups of balani, and sundry others

3407 A tortoise-shell harp, two occidental argus porcellanæ, and, three various bivalves

3108 Two of helix variegata, (citrina, Linn.) two orange mouth, olives, two brown caterpillar clubs, and three others-all from China

3109 The map porcelain, a young brunette porcelain, (tellina scobinata, Linn.) China; and the crimson zoned pectunculus, New S. Wales

3110 Harpa nobilis, Philipine Isles, very rare; the cocoa nut fresh water shell, Barbadoes; a scarce ark, China; and cardium arundinosum, S. Seas

3411 Anomia terebratula, Linn. with several of a curious species of serpula partially affixed to it, from Minorca; a beauty. limpet, Cape of G. Hope ; the rayed mask, Falkland Isle ; and a cardium hemicardium, Linn. - all rare $1 / 4$

3112 A young leopard porcelain, the bellied variety of the occidental argus porcelain, Providence; and a bear's paw clamp 
3413 The wampum clam, (Venus mercenaria, Linn.) the long mussel, Bairbary; a South Sea swallow margaritifera, and two more

3414 The poached egg shuttle, a beautiful panther porcelain, the honeycomb porcelain, uncoaied, S. Seas; and a paitited clam, China o thy

3415 The flame and painted pectunculus, China; the bellied clam, $S$. Seas ; two dwarf lcopará porcéllanæ, and a distempereit nutmég porcelain

3116 Arca tortuosa, Tranquebar; chama calyculata, Linn. oue valve of a rare ark, N.S. IVales; and three other bi.. valves

3417 The Medusa s head limpet, Bartary; the mole hill porcelain, Guinea; and a red furbellowed clamp, China

3418 Solen rostratus, or beaked violet solen, Tranquebar; a scarce English clam, (Venus incrassata, Soland.) two other uncommon bivalves, and two young spider strombus $y^{\prime}-3 .+0$

3819 The great mamillated turban echinus, with its spines, from New South Wales

3420 A fine voluta nobilis, from China, very rare

3421 Eight impressions of vegetables in nudules of argillaceous iron of?

3422 Two sections of a fossil nautilus shewing the chambers, and a mass of limestone with various sparry casts of ammonita:

3423 Five different kinds of fossil madrepore

3424 A variety of parts and fragments of belemnita

3425 Two fossil palates of fist, \&c.

3426 Several casts and fragments of ammonitæ

3427 Fourteen vegetable impressions in argillaceous iron ore

3428 Six different species and varieties of fossil madrepore

3429 Impression of fossil bark of the reed kind, and its counterpart

3430 A mass of various shells of the ostrea, and pecten genera, fragments of the latter tinged with colour, apparently that of the natural shell; and an ammonite

3431 Remarkably large and fine polished slab of fossil ammonites

3432 Casts of a variety of the ammonitæ in spar, pyrites, \&co

3433 Impression of a very singular coralloid body, and three other coral petrifactions

3434 A mass of marine remains, and an ammomite

3435 A large mass of the cornu Ammonis, and its counterpart

3436 Two fragments of ammonites, and two other fossils

3437 Three fossil corals, and a curious cast of another, Maestricht

3438 Eight various impressions of ferns in argillacéoús iron ore

3439 Two sections of a fossil nautilus, in limestone 
3440 An extremely curious and finely displayed impression of a lobster, in a slab of marl, Papenheim

3141 Buprestis vittata, and a variety of the carabus, and other genera

3442 Twenty-four insects chiefly of the apis tribe

3443 A number of coleopterous insects of the genus scarabeus

3444 Buprestis sternicornis, gigantea, cicindela Germanica, buprestis marginalis, \&c. - fourteen specimens

3445 Twenty-five insects of the melolontha, scarabeus, and other genera

3446 Fulgora candelaria, gryllus roseus, tettigonia picta, and seven others

3447 Gryllus campestris, cicada cormuta, and thirteen insects of the hemiptera order

3448 Twenty various cimices, nepa linearis, and two others

3449 A small specimen of the white shark, and another of the flounder, pleuronectes flessus

3450 The carp

3451 A fine specimen of the zebra frog, rana zebra

3452 An excellent specimen of the mourning snake

3453 Scorpæna porcus, Mediterranean

3454 Boa phrygia, or embroidered boa, an elegant specimen

3455 A very large and curious snake

3456 Pearl spar on crystallized quartz, Cumberland--two specimens

3457 Cubic amethystine fluor of a very dusky hue, almost approaching to black, Derbyshire

3458 A very large and fine specimen of crystallized calcareons spar, from ditto

3459 Three varieties of arsenical copper, and one crystallized tin, Cornwall

3460 Iron ore, Germany ; two crystallized tins, Cornwall; and garnets on shorl, \&c.

3461 Violet cubic fluor, on a group of spar, Derbyshire; gray cubic ditto, internally sprinkled with marcasites, Leicestershire; greenish ditto with the edges bevelled, and dark purple cubic ditto

3462 Three varieties of arsenical copper and another; one arsenical iron; and shorl with mica, \&c. Cornwall

3463 Five varieties of arsenical copper and iron, Cornwall; and green malachite, Somersetshire

3464 A fire specimen of arseniate of iron, and two beautiful varieties of arseniate of copper. Cornwall

3465 Three varieties, arseniate of copper and iron, Cornwall; and three others

3466 Two specimens of steatite, one from Derbyshire, the other from Cornwall

3467 A group of the ovæ of oestri 
3468 The cærulean snake, an oyster, and larvæ of sphinges

3469 A curiously contorted carrot, and a fruit-in two bottles

3470 A singular lusus of a raddish, and three snakes

3471 Clupea pilcardus, two specimens

3472 Double banded chætodon, and the zebra fish

3473 Exocœetus ævolans, flying fish, and a marine fasciculated worm

3474 The spotted tortoise, a lizard, frog, and two others

3475 An ocellated snake, and banded snake-in two bottles

3476 The blue spotted lizard, and a curious frog

3477 Four handsome specimens of German agate, and one Oriental

3477 Gold, on arsenical pyrites, Hungary

3478 Gold, in nickel, very rare, Siberia

3479 A large and curiously figured polished specimen of agate, Oberstein

3480 Very finely executed bronze figure of Venus

End of the Twenty-ninth Day's Sale. 


\title{
THIRTIETH DAY.
}

\author{
Monday, the 9th of June, 1806.
}

3481 Portrait of Oliver Cromwell, in cut paper 2

3482 Three small specimens of cut paper, framed and glazed $2-6$

3183 Drawing of the pea hen (lot 2310) which at the age of eleven put forth the plumage of the male bird, (framed and glazed)

3484 Elegant flower piece in cut paper, ditto $1=6$

3485 An elegant yellowish fluor vase

3486 A pair of honey-comb fluor vases

3487 Fossil marble vase, and a pair of saits formed of fluor 6

3488 A handsome pair of purple fluor ornaments $/ 4$

3489 Iigenious representation of engravings, executed in com. position $6-6$

3190 The Ten Commandments, curiously cut in paper, in Byrom's short hand I

3491 A fluor vase of a beautiful and singular pattern

3492 A capital specimen of penmanship, by Mr. Tompkins, framed and glazed $\delta-\gamma 0-0$

(3493 Body of a vase, formed of rich orange-colcured fluor

3493 A large and handsome fluor vase, partly broken, and various parts of vases, \&c.

3494 A polished slab of fossil ammonites $/ /$.

3495 Three frames, containing inlaid specimens of florentine and other marbles

3496 Body of a fluor vase, with a porphyry base, and an ornament formed of inlaid marbles

3197 Singularly constructed bird cage, said to have been made by a person born blind 
3498 Inlaid wood, representing a lion, \&c. 2 - 6

3499 A very curionsly carved pair of ancient English bellows $1-3-0$

3500 A large Vive la Plume, by the late Mr. Brown of Norwich, esteemed one of the finest specimens of penmanship ever produced $2,0=0$

$35 \cap 1$ Bearded titmouse, m. and fem. 18

3502 Blue breasted finch

3503 Black-headed gross beak, m. and fem. S. America -6

3504 Turtle dove, Lancashire; and coddy moddy guh, two cases

3505 White rook 6.6

3506 Royston crow, Corvus cornix

3507 Rose-ringed parroquet, m. and fem. Psittacus Alexandri, var. $y^{2}=0$

3508 Shell duck, $m$. and fem.

3509 Tufted duck, Anas fuligula

3510 Red fronted parroquet, S. Seas $/ 5$

3511 Golden thrush, hen, Holland $9-6$

3512 Small goatsucker -6

3513 White variety of linnet $/ \ell-6$

3514 Ditto of sparrow $/ 2$.

3515 Snow finch, hen; and chaffinch, male-two cases / $/ 2$.

3516 Supercilious kingsfisher, Alccdo superciliosa

3517 Fulgora candelaria, tettigonia atrata, nepa rustica with the eggs on its back, the vegetating wasp, and seventeen other insects 4

3518 Rhaphidia maxillosa a pair 9

3519 Chrysomela punctata, maculata, nitida, șeveral coccinellæ, \&c. thirty-nine specimens 2 .

3520 Various insects of the cerambyx genus, staphylinus rufus, and several others, including twenty-nine specimens 6

3521 Caralus nitens, and a variety of small insects of the locusta leptura, cimex, and other genera -6

3522 Elater pectimcornis, scarabæus carnifex, elater striatus, several of the cetonia and other coleopterous genera, in all thirty-one 18

3523 Chrysomela gigantea, cassida bimaculata, and various chrysomelæ and cassidx 15

3521 Three curious insects of the gryllus tribe

3525 Wryneck, Yunx turquilla 5

3526 Paradise grosbeak, Loxia erythrocephala, m. and fem./4

3527 Robin, variety 5

2528 Whidah bird, Africa .

3529 Kingsfisher, $S$ Seas Alcedo Smyrnensis, var. -6

3530 Silky fowl, E. Indies $4-6$

3531 Eleven various specimens of vegetable impressions $/ 8$

3532 Four belemnitæ and a fossil madrepore 6 
3533 Five various coralloid bodies, and a piece of fossil wond perforated by teredines

3534 Fragment of a singular ammonite, and casts of several others

3535 A large fossil ammonite, retaining a small portion of its pearly or inner coat

3536 Several belemnites, coralloids, shark's teeth, '\&c.

3537 A variety of small vegetable impressions in argillaceous iron ore 12

3538 Fossil wood, shells, and other petrifactions

3539 Casts of various coralloid bodies, \&c. 2 - $~ \&$

3540 Eleven different specimens of Bufonites, and parts of palates $3-9-0$

3541 Fragments of corals, nautili, from Sheppy, \&xc.

3542 Seventeen various corals, impressions of corals, and other petrifactions

3543 Large and curious jointed cast of a singular ammonite

3544 Two large nodules of argillaceous iron ore, with their counterparts, and two sinaller, containing each a single leaf 19

3545 A variety of shells of different genera and species, among which are the quaker lunatus, the notched bull's eye snail, the lineated cuma, the bleeding teeth nerita, \&c.

3546 The bread-basket clam (Venus fimbriata, Linn.) and the painted clam, China; a scarce pectunculus, W. Indies; the pear, and granulated limpets, Cape of Good Hope; and a mole-hill porcellain, Guinea

3547 A large diadem echinus, $W$. Indies; and two others, one having its spines, English coast

3548 A finely furbelowed long clamp from Madagascar; and two large and fine porcellanæ

8549 A mamillated echinus, Arabia; and two other diadem echini, one having its spines, Sicily \&

3550 The strawberry cockle, two tiger chersinæ, a tortoiseshell harp, and tiwo others

3551 A large and fine chama hippopus, Linn. or bear's paw clamp, E. Indies 0

3552 Various spines of echini, chicfly of the club and lanceolated kind

3553 A large and fine tiger chersina, having its epidermis complete, from Guinea, rare

3554 Conus fulgens, from Ceylon; the box-wood cone, China; and the pyramid trochus, from the Maldivian Isles 6

3555 A very large moor rhombus (murex moris, Linn.) Island of St. Thomas, rare; and a young specimen of the great W. India helmet

3556 The long purple spot oyster of a large size, Virginia, rare 
3557 Two beautiful reverse chersinæ, from China; and a fine stair case

3558 The urn melon, from Sicily; and two spider strombi, from China

3559 Two large magpie apiculi, W. Indies; a scarce triplex, Tranquebar; and a zebra trochus

3560 The marbled snake shell, curiously etched with various devices, China

3561 A scarce fresh water shell, Cape of Good Hope; a rare white tower, Martinique; a smooth ditto, Tranquebar; and four needles

3562 A fine conus imperialis, a large ribband snake, and a leopard cone

3563 A very large trajan's column needle, and a rare cuma 8

3564 The purple ringed trochus, the razor-edge carrier, and a globose pyrum, all rare -0

3565 A very fine variegated spondylus, South Seas, rare 6

3566 Partridge, a curious white variety

3567 Duck, male and female

3568 Red breasted goose, Russia

3569 Blue headed parroquet, Isle of Borneo

3570 Fine specimen of grayish cubic fluor, with bevelled edges, Derbyshire; and minute violet cubic ditto, on calcareous spar

3571 Hen harier hawk, Falco cyaneus $f-f-6$

3572 Loxia cardinalis, m. and fem..

3573 oodcock variety $i-2-6$

357.4 Ptarmigan $f=0$

3575 Long-tailed whidah bird, m. and fem. (two specimens of

3576 Young pea fowl the male in different stages of plumage) $2 \cdot 3-0$

3577 Bonana bird o

3578 Loxia curvirostra, $\mathrm{m}$.

3579 Turdus pilaris

3580 Madagascar roller, coracias Madagascariencis 10

3581 House sparrow, both sexes, with the egg, and a Tringa pugnax

3582 Bald headed parrot, Brasils $/ 1 \cdot 6$

3583 Charadrius himantopus, long legged plover

3584 Three elegant specimens of agate, cut and polished

3585 Ampelis Pompadora, Pompadour thrush $/-8$ -

3586 Thick kneed plover, $m . \mathrm{fem}$. and young $/ . \gamma \cdot 0$

3587 Long triled jay, America

3588 A small tringa 3589 Whitish cubic fluor, with galena, Derbyshire

3590 Ardea gardenia ity

3591 Merops fasciculatus, yellow tufted bee eater, $m$. and fem. rare $3-44-0$ 
3592 A large fluor vase, diversified with galena and marcasites 3593 A large onachine jaspar, and ribband jaspar, Siberia 3594 Lapis lazuli, Siberia; and wood-like jaspar, very fine, in colour

3595 Four varieties of arsenical copper and iron, Cornwall; green shorl, and another $4=$

3596 A pair of remarkably beautiful fluor obelisks, elegantly diversified with pyrites

3597 A remarkably large slab of Egyptian pebble

3598 Auriferous pyrites, Siberian-scarce

3599 Brasilian native gold, in quartz, a rich and beautiful spe-

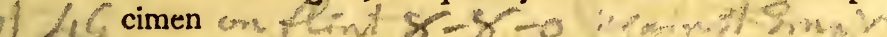
3600 Two perfect and corresponding articulations of basalt, from the Giants Causeway, Ireland

End of the Thirtieth Day's Sale. 


\title{
THIRTY-FIRST DAY.
}

\author{
Tuesday, the 10th of June, 1806.
}

3601 Garg.ANY, Anas querquedula
3602 Gray godwit 16
3603 Mocking thrush, Turdus Orpheus
3604 Turtle doves-three specimens

3605 Striated turtle doves-three specimens $/ 0-6$

3606 Small African parrot, Psittacus pullarius /2

3607 Brown silky fowl, m. and fem. East Indies $4-6$

3608 Cuckow, m. and fem. It/

3609 The sucking fish, echeneis remora, and the blue snake, in two bottles 3-6

3610 A gurnard, the larva of an exotic moth, and a cerambyx with a frog $1-6$

3611 A sepia, and a speckled toad 3

3612 A young crocodile, in spirits is

3613 A scomber, diodon, blennius, and three others 3-6

3614 Pintado snake, meleagris, a spinous larva of an oyster $3-6$

3615 Testudo picta, the painted tortoise, a fish, and another $\Sigma=6$

3616 Fasciated frog, nearly allied to rana zebra 4

3617 The blue frog, an elegant snake, and a lizard $/ 1-6$

3618 A ribband snake, spotted ditto, an aphrodita aculeata, and the cashew nut

3619 Julus grandis, pleuronectes, and a bat in spirits $=6$

3620 Banded snake, a gecko lizard, and another $\&-6$

3621 Lacerta stellio, the muricated lizard, scurce

3622 Brown banded snake, and a scomber

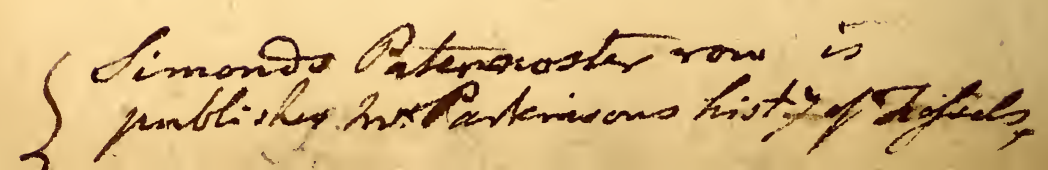


3623 A parasitic crab, a scomber, and two snakes

3624 Lettered tortoise, testudo scripta, gecko lizard, and a snake 2!

3625 A small armadillo, lateral banded lizard, and a snake

3626 Weaver fish, banded chætodon, two snakes, and fivelined lizard 6

3627 Yellowish monkey of Pennant, very scarce fo

3628 The bay monkey, extremely scarce $4-14-6$

3629 Lemur mongoox 10 - 6

3630 Two specimens of that very rare animal, the Sciurus variegatus, or varied squirrel, Onalaska $1-1-0$

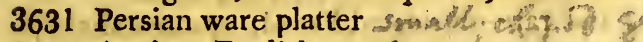

3632 Ancient English watch //

3633 A pair of bronze figures, from Herculaneum $t=2-0$

3634 An equestrian figure, from ditto $3 \cdot 15-0$

3635 Ancient penance girdle $3-6$

3636 Curious ancient snuffers

3637 A brass celt, and a stone ditto

3638 Ancient purse $2-6$

3639 Singular small ancient chest 2

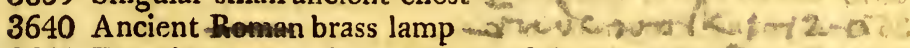

3641 Egyptian urn, inclosing bones of the ibis

3642 Ancient Roman urn $/$ a $l$ in

3643 Elegant pouch made by the North American Indians, formed of porcupine quills, beads, \&c. $/ 3=6$

3644 Head dress of ditto

3645 Two small figures dressed in the costume of the N. American Indians 18

3646 East Indian Hat

3647 Chinese organ $y-3-0$

3648 Curious ancient cup, found in the ruins of Kenilworth Castle models of fruit, and ditto of a candle

3649 Three models of fruit, and ditto of a candle
3650 A most beautiful long ebony Turkish lady's pipe, richly jointed with fine amber and lapis lazuli, and haring the bowl set with rubies. This was the property of the Hon. Wortley Montague $3+7=$

3651 Fossil ammonite of a large size

-3652 Fifteen various fragments of fossil crabs $1-11-6$

3653 Twenty-two small specimens of fossil corals, \&xc.

3654 A large mass of the black leech palate

$\$ 365$ A variety of marine remains, and other petrifactions $/ 4$.

3656 A great variety of petrifactions, shark's teeth, belemnitre

3657 Four casts of ammonitæ, parts of nautili, \&c.

3658 Large shark tooth, Malta ; various bufonites, parts of pa. lates, \&c. 9

3659 Sundry belemnita, and other fossils 
3660 Part of the head and anterior portion of the body of a fish, imbedded in marl, Sheppy.

3661 Three portions of fossil cancri in marl, and an anthropo-

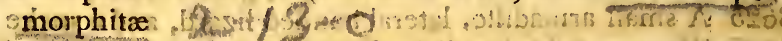

8662 Several casts and sections of small ammonitæ, natili, \&cc.

3663 Six casts and impressions of cancri, \&c.

3664 A small chamaleon; frog, fish, and another

3665 Aphrodita aculeata, blue snake, speckled lizard, and another

3666 Eight:banded chætodon, and another fish, striped snake,

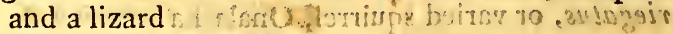

3667 A very curious and rare muricated lizard, spotted snake? and a fish

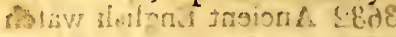

3668 An elegant specimen of the harlequin angler, lophius histrix, diodon, flying fish, and two more

3669 Green speckled lizard, fasciated snake, and two locustæ

3670 A small saiamander, blue snake, iand two others iss $\mathrm{d}$ ! ?

3671 Raja turpedo, the electric ray

$3672 \mathrm{~A}$ brace of mullets, and a slow worm tis is 860 to

3673 Gecko lizard, speckled lizard, and anotlier 'tagn?

3674 A young Kangaroo, in spirit

3675 The ringed snake; boa cenchris, very rare and curious

3676 Lacerta gecko, a well-preserved specimen 140

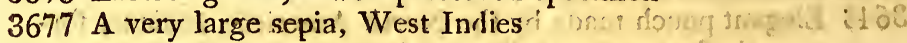

3678 Brown banded snake, and variegated ditto

3679 Lineated old wife fish, two specimens

3680 Medusa pulmo, from the Brighton Coast

3681 Sparus auratus

3682 Horned scorphæna, double bellied snake, two marine onisci, vermes, \&c.-five bottles

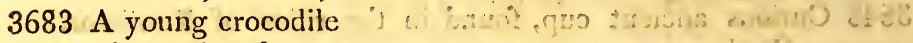

3684 Lineated snake

3685 Ceylon crocodile of Seba, a rare and interesting article

3686 Scorpio afer, four elegant snakes, and a lizard

3687 Testudo guttata, a small salamander, two snakes, a speckled lizard, and spotted goby

3688 Gryllus campestris, three curious snakes, and a frog

3689 Spotted tortoise, and another, a snake, and two fishes I I ¿jof

3690 Scutated lizard, lacertä scutata, vur. Ceylon

3691 A mytilus and lepas, with adhesions; sabella; an aphrodita, larva of an insect, and two others

3692 Single spined balistes, three curious snakes, small spotted toad, and another

3693 A curious lophius, or angler fish, two snakes, and two fishes

3694 Two leopard porcellanæ, two young ditto, another shell of the same genus, a young spider strombus, and three $0 \hat{0}$ more 
3695 Two mamillated diadem echini, with their spines, from Sicily

3696 Two brown many-wheeled screws, two swamp clubs, two of acus duplicatus, and eight othets: : 10it: 5 ,

3697 A painted clam; the great rayed mask, Falkland's Isle;

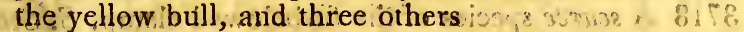

3698 A rare cordated echinus; $W$. Indies; and two diadem storre of echini, one having its spines, Sicily enf.,osius

3699 The Dutch bonnet limpet, two porcellanæ, a tortoiseshell

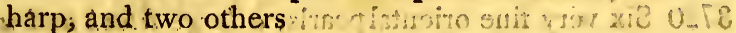

3700 Cubic fluors of a greenish tint, formed on cockscomb marcasites with spar, Derbyshire

3701 Elegant specimen of violet cubic fluor, having the edges delicately pencilled with a deeper tint, Derbyshire; very dark amethystine ditto, from ditto

3702 The violet winged and starred echinus, from China, very scarce

3703 A small Ethiopian crown; a pink harp, from Guinea; and two curious species of anomia

3704 A very large tridachna ursina, or bear's paw clamp, E. Indies

3705 Two black coronated spiral fresh water shells, from the Ganges; a beehive helix, two zoned lucernæ, two other terrestial shells, and two banded lapwing`s egg bullæ

3706 A large specimen of brown cauk, cut and polished, Derbyshire

3707 The pale brown club spined echinus, St. Mauritius, very rarelue 2 isnce ser.

3708 Stellated gypsum, Sheppy ; sulphate of strontian in large plates, Bristol ; barytes, and brown rock crystal

3709 Very large mass of crystallized calcareous spar, Derbyshire; a dark coloured stalactite, from ditto; bubbled calcareous spar, from ditto; and white quartz crystals, Cumberland

3710 The cinnabar, and another pecten, a tulip tellen, a distorted mytilus demissus, and two other bivalves

3711 Ruby-coloured blend, with quartz crystals, and delicate amber-coloured plates of crystallized barytes

3512 Grey crystallized antimony, having the crystals nearly complete, and stellated needle antimony on tabular barytes

3713 A large marbled snake shell, China

3714 Two of the pink mouthed shuttle, (Bulla imperialis, Soland.) from the Friendly Isles; the fluted glycemeris, (Arca pectunculus, Linn.) the flame and camp clams, from China; and a singular variety of conus fulgens

3715 Two yellow mouth olives, a violet mouth and another olive, two mitres, a red bulla, and two land shells 
3716 A rare cardium, Tranquebar; the globose pectunculus, $S$. Seas; the rasp pecten, China; the agate porcelain, Otaheite; and two others

3717 Donax scortum and mactra violacea, Soland. from Tranquebar; and the sardonyx and honeycomb porcellanæ, from Otaheite

3718 A scarce species of the furbelowed clamp, S. Seas

3719 The noble harp, from the Philippine Isles, very rare; peca tunculus literatus, Amboyna; and a young brunette porcelain

3720 Six very fine oriental pearls, a large lilack and white pearl, and four valves of double shells, with pearls attached to them

End of the Thirty-first Day's Sale. 


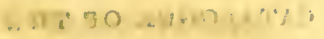 \\ THIRTY-SECOND DAY.}

Wednesday the 11 th of June, 1806.

3721 MONSTER pig, with a proboscis

3722 Four monster chickens, with double heads, \&c,

3723 Cyclop kitten

3724 Monster dog, with eight legs

3725 Singular monster kitten

3726 Double headed kitten

3727 Monster pig, having eight legs

3728 Feet and hands of an Egyptian mummy

3729 Cat, which was found starved to death with a rat in its mouth

3730 Monster duck, having four legs

3731 Injection of a male subject, aged five years

3732 Ditto of a ditto, aged seven

8733 Ditto of a female, aged nine, together with an injected heart, a ditto arm, and a small skeleton

$3734 \mathrm{Leg}$ and feet bones of a boy, whose foot and leg were burnt whilst he was in a state of lethargic sleep

3735 Three monster kittens, with eight legs, double tails, \& $\mathrm{c}$.

3736 Duck, with a distorted head

3737 Dog, with eight feet, \&c.

3738 Singular monster canary bird

3789 Monster duck, with four legs, \&cc.

3740 Double headed monster calf

3741 A human fetus, aged about six mouths 
3742 A human fœtus, aged about six months

3743 A ditto ditto

3744 A mulatto ditto, aged about seven months

3745 Two monster kittens, in spirits

3746 Full grown monster duck, in ditto

3747 Cyclop pig, with a proboscis, in ditto

3748 Cyclop head of a full grown dog, in ditto

3749 Egyptian mummy and case

3750 Arms of Egyptian mummy

375 Monster duck in spinits.

3752 Double headed monster calf

3753 Eight legged monster kitten, in spirits

3754 Duck, with the skin injected, in a glass bottle in spirits

3755 Monster pig, with eight feet

3756 Monster duck, in spirits

3757 Monster kitten, in spirits

3758 Double headed monster chicken, in ditto

3759 A human foetus, aged about seven months

3760 A ditto, aged nine months, with the umbilical chord, \&c.

3761 Hoofs of the whole footed pig, in spirits

3762 Human hand, in the act of grasping a sword hilt. The body, from which this hand was taken, was discovered in digging, and is supposed to have been a person

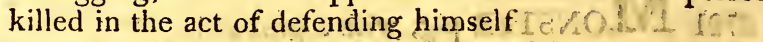

3763 Monster partridge, with three legs, in spirits

3764 Dog, partly dissected, in spirits, and another

3765 Two bottles, containing foetusses of quadrupeds; in spirits

3766 Monster dog, with eight legs

3767 Cyclop kitten

3768 Part of the vertebræ of a whale, and two teeth

3769 Double headed kitten, and four legred duck

3770 Two curious imitations of animals of the buffalo kind

3771 An injection of the human cranium, bisected; raud jawbone of a subject; aged upwards of sixty, with all the teeth perfect

3772 Two joints of a whale's back bone, and two teeth

3773. Lingoa de peixe piraurueu, and other parts of curious fishes

3774 Horns of elk, Germany

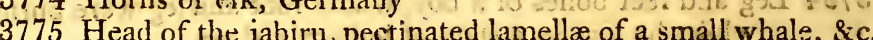

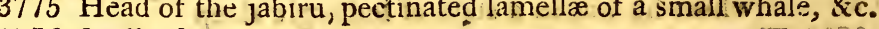

3776 Scull of porpoise

3777 Various parts of animals as tusks of the sea lion, Falkland Island, \&c.

378 Part of the scull of the sea cow (trichecus rosmaruis) with the tusks

3779 Part of the hide of the rhinoceros, sharks teeth, fish bones, \&c.

3780 Horn of the monodon monoceros, about eight feet long 
3781 Skin of the boa constrictor, upward of fifteen feet long 3782 Tooth of the spermacefit whale, and pectinated lamella or zuc comb of a small whale.

3783 Scull of the monodon monoceros, with the horn

3784 Horns of the elk. Nova Scotia

3785 Head of the sword fish, with the snout and jaw of shark

3786 Large saw of saw fish

3787 Tooth of the hoppopotamus, ditto of the sea lion, an incur-

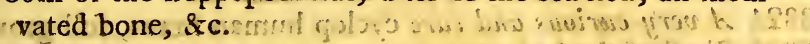

3788 Barbed spine of the sting ray, bladder of the porpoise, and

- various parts of fishes.

3789 Remarkably large ox`s horns

3790 A singular osseous aggregation, and part of a jaw

3791 Head and horns of rein deer

3792 Leg and horns of the small African deer, \&c various

3793 Curious under jaw of an animal unknown, jaws of fishes, 3 \&c.

3794 Part of the hide of rhinoceros

3795 Curious head of a hornbill, ditto toucan, skeleton of a bird's head, and ditto fish $s$

3796 Horns, Virginia ; very curious, from having an additional branch

3797 Two pair of remarkably contorted ram's horns

$3798 \mathrm{Head}$ and beautiful horns of antelope

3799 Remarkably large' horn of the rhinoceros

380 . Horn of the rhinoceros,' and tusks of the Otaheitan hog

3801 Two feet of a full grown pig, with the hoof branched into

- five distinct processes

3802 Ox's horns of uncommon magnitude

3803 Parts of various palates of fishes

3804 Hippocami, two specimens, trunk fish and porcupine fish

380,5 Curious antèlope's horns

3806 A very singularly formed bone of some unknown animal

2807 Beak of the helmet horn bill

3808 Various fragments of fish palates, a curious skull, beak of the cuttle fish, \&c.

3809 Head of the rhinoceros bird

3810 Tooth of the spermaceti whale, and a paw of a large seal

3811 Horns of Indian buffalo

3812 Head of the common jack pike of a large size

3813 Bone of the cuttlefish; jaw of a fish; bone of a porpoise

3814 Various fragments of palates, head of a gurnard, \&c.

3815 Head of the rhinoceros bird, a fine specimen

3816 Upper mandible of the hornbill, and head of the jabiru

3817 Grinder of the common elephant cut in two to show the internal structure

3818 Transverse section of the African elephant's grinder, and a longitudinal section ditto 
3819 Two curious palates of a fish, West Indies

3820 Part of the tooth of a whale, beaver's jaw, hoof of a young zebra, and horn of an antelope

3821 Bufonites teeth, parts of several fish palates, \&c.

3822 A singularly formed root, resembling a hand, skeleton of the winter cherry, a foetus, and a parcel of eggs

3823 Head of the hornbill, and ditto albatross

3824 A very curious and rare cyclop human fotus; full grown

3825 Skull of the beaver

3826 Human foetus of about two months growth, with the membrane perfect

3827 Fætus; somewhat younger, with ditto

3828 A very singularly constructed bone of some animal unknown, barbed caudal spine of the stingray

3829 The internal part of a curious horn, and a very remarkable bone of a fish having a large osseous appendage

3830 Tusk and two teeth of the hippopotamus

3831 Monster cyclop pig, in spirits

3832 Very complete skull of the babyrussa

3833 Skeleton of a monkey

3834 Horns, supposed to be excrescences formed on the human head

3835 Part of a curious palate of a fish

3836 An extremely interesting specimen of the scull of the seaunicorn (Monodon monoceros). having two perfect horns

3837 Full grown monster foetus without any neck

3838 A large and very perfect scull of the hippopotamus, having the tecth and tusks complete

3839 A large corneous excrescence, supposed to have been formed on the human head

3840 Scull and ivory tusks of the elephant, which, when living, belonged to her present Majesty

End of the Thirty-second Day's Sale. 


\section{- Catalogue}

\section{OF THE \\ LEVERIAN MUSEUM,}

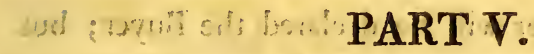

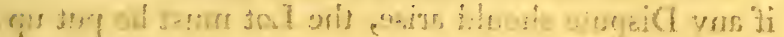

INCLUDING THE FIFTH EIGHT DAYS'SALE.

* the remaining parts wilt be published with all. POSSIBLE SPEED.

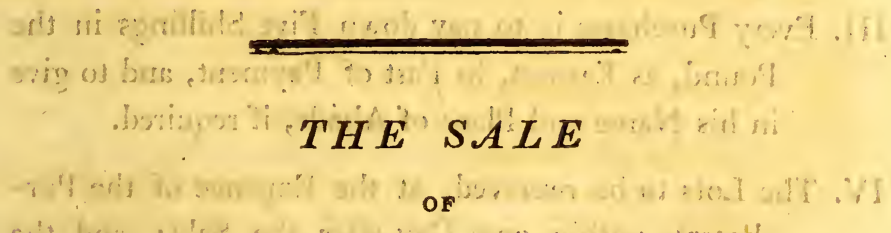

\section{THE ENTIRE COLLECTION}

\section{(By Messrs. KING and LOCHEE,)}

\section{WILL COMMENCE th thit}

On Monday, the 5th of May, 1806, at Twelve o'Clock,

In the Building now occupied by

\section{THE MUSEUM.}

The six Parts of the Catalogue already published, (Price 5s. 6d.) to be had at the Museum; at Messrs. King and Lochée's, (the Auctioneers) and at Hayden's Printing-Office, Brydges-Street, Covent-Garden.

Hayden, Printer, 4, Brydges Street, Corent Cardes. 


\section{CONDITIONS OF SALE.}

1. THE highest Bidder will be declared the Buyer; but if any Dispute should arise, the Lot must be put up again.

II. No Advance less than Sixpence; above One Pound, One Shilling; above Five Pounds, Five ShilLINGS.

III. Every Purchaser is to pay down Five Shillings in the Pound, as Earnest, in Part of Payment, and to give in his Name and Place of Abode, if required.

IV. The Lots to be removed, at the Expence of the Purchasers, within one Day after the Sale; and the Remainder of the Purchase-Money to be paid on or before the Delivery.

V. Upon Failure of complying with the above Conditions, the Money deposited in Part of Payment shall be forfeited. All Lots uncleared within the Time aforesaid, shall be re-sold, oy public or private Sale; and the Deficiency (if any) attending such Re-sale, shall be made good by the Defaulters a this Sale.

Gentlemen who cannot attend the Sale, may have their Commissions faithfully executed, by their humble Servants; 


\title{
THIRTY-THIRD DAY.
}

\author{
Thursckay, the 12th of June, 1806.
}

3841 A VERY handsome pair of ancient English shoes, and another pair

3842 Highly ornamented ancient English slippers, and another pair

3843 Two pair of ornamented Canadian shoes

3844 Ancient English gloves, and morocco slippers

3845 Peasant's shoes, Denmark ; and ditto, French

3846 Ancient English shoes, and French slippers

3847 Four pair of sandals of various kinds, and part of a lady's dress

3848 Ancient English shoe and clog, and model of a shoe worn by Gervas Moreton of Odiham, when at the age of eighteen

3849 Elegantly ornamented Chinese shoes

3850 Curious ancient English shoe, found in pulling down an old house at Ashton under Line, 1743; and an ancient English clog

3851 Chinese gun, ornamented with silver ferrules

3852 Old English pistols

.3853 Ancient English pistols, with ornamented iron stocks

3854 Ditto, with brass stocks

3855 Long Persian gun, with a curiously inlaid stock

3856 Richly ornamented gun, with Damascus steel barrel, formerly the property of the Hon. Wortley Montague

3857 Gun, supposed to be ancient English

3858 Ancient English pistols, with finely worked iron stocks

3859 Ancient English he]met, and another 
3860 Ditto breastplate, and two other parts ornamented 3861 . Ditto helmet

3862 Ditto helmet, armour for the back, and two other pieces

3863 Ancient belmet and breastplate

3864 Ditto gauntlets

3865 Ditto armour for the arm, and ditto for the shoulders, \&c.

3866 Armour for the body complete

3867 Remarkably large brass barrelled blunderbus

3868 Curiously engraved African powder-horn

3869 Persian gun, with the stock curiously inlaid with mother of pearl, \& $\mathrm{c}$.

3870 Richly ornamented pike, which belonged to the Mogul's guard

3871 Six gun-locks, old English

3872 Five gun-locks, old English

3873 Singular Chinese gun, ornamented with silver ferrules

3874 Persian powder-horn, and African ditto

3875 Ancient English breastplate, and armour for the arm

38:6 Ditto breastplate and helmet

3877 Ditto armour for the back, and ditto.

3878 Ditto and ditto

3879 Dit to arm armour, and two others

3880 Ditto, ditto, and armour for the back

3881 Spontoon, English

3882 Ancient English battle-axe

3883 Crossbow

3884 Large ancient English corporation sword

3885 Pistol and battle-axe in one, with handsome inlaid handle; Turkish

w 3886 Ancient English shoulder armour, and a helmet

3887 Ditto arm armour, and a breastplate

3888 Ditto, a breastiplate, and armour for the back

3889 Ditto breastplate 3890 Lady's full dress stiffen boddice, in Charles the second's
time

3891 Lady's jachet, Charles the first's time

3892 Ruff (Queen Elizabeth's time) and a jacket

3893 Ancient English gloves, and a curiously constructed ancient basket

3894 Two handsomely worked ancient English matts

3895 Regimental gloves (Charles the first's time)

3896 Bishop's gloves ditto, and ancient English hat

3897 Lady's sattin jacket, ancient English

3898 Gentleman's ornamented linen coat, and a pair of gloves, ancient English

3899 Gentleman's ornamented lcathern coat (Charles the first's time)

3900 A Colonel's coat (Charles the first's time) 
3901 Oliver Cromwell's helmet, gorget, armour for the body, and left arm, and leathern surtout, which were given by a lady (a descendant of General Disborowe's) to Mr. Busby, and by him presented to Sir A. Lever. Tpey weigh $36 \frac{3}{4}$

3902 Alca torda, the auk

3903 Long legged plover, charadrius himantopus

3904 Lanius, excubitor, both sexes

3905 The common jay male

3906 Jackdaw

3907 Oriolus persicus, black and yellow oriole, Brazils

3908 Blue jay, corvus cristatus, Canada

3909 Golden crowned manakins, a pair

3910 Wood owl

3911 Striated dove, Columba striata, and a pair of the small turtle dove

3912 White variety of the common fieldfare

3913 Icteric oriole, oriolus icterus

3914 Largest snipe shot in England, one specimen without case 3915 Tyrant shrike, lanius tyrannus, $\mathrm{m}$. and fem.

3916 Rose coloured ouzel, turdus roseus, extremely rare

3917 Dial grakle, gracula saularis

3918 Picus auratus, gold winged woodpecker

3919 Perdix cristata Lath, crested quail, Mexico-rare

3920 Pied shrike, lanius doliatus

3921 Piperine toucan, Ramphastos piperivorous

3922 Oriolus cristatus, crested oriole, m. and fem.

3923 Papilio Hector, Memnon, and six other butterflies

3924 Papilio Apollo, and four other insects

3925 Papilio Heliacon, rare

3926 Papilio Iris, Agamemnon, Memnon, and nine others, among which is a new species, Papilio Assaracus Don.

3927 Papilio Apollo, and seven other butterflies

3928 Papilio Delia, Comma, Io, and nine other butterflies

3929 Papilio passiflora, several of the fritillaria, and other papiliones

3930 Scarabœus sacer, carabus bimacalatus, a lampyris, buprestis vittata, \&c. twelve specimens

3931 Blatta heteroclita, nepa rustica, a curious variety of mylabris cichorei, apes, cimices, \&c. twenty-four specimens

3932 Scarabœus molossus, lucanus ruber, curculio nitens, and two more

3933 Two curious larvæ of the phasma genus, and a mantis

3934 Thirty-five insects of the ichneumon genus chiefly, among which are ichneumon gigas, scolia flavifrons, \&c.

3935 Mantis siccifolia in the winged state, rare

3936 Buprestis imperialis, a lucanus, and three scaraboei

3937 Ichneumon purpurescens, scolia cinctus, scarabœus sacer, \&c. thirty-three specimers 
3938 Melolontha fullo; scarabœus Perseus, four specimens

3939 Silpha Americana, scarab'ous fullo, lucanus depressus, and two more

3940 Scolopendra morsitans, truxalis viridis, locustæ, grylli, \&c. eight specimens

3941 Cicada lanata, tettigonia australasiæ Don. blatta irrorata, nepa grandis, blatta heteroclita, \&c.

3942 Fulgora candelaria, papilio delia, Erymenthis, \&sc. altogether fifteen specimens

3943 Two large specimens of quartz crystallised

3944 Five specimens of agate, Scotland ; and a piece of puddingstone polished

8945 Two crystallised tins, pure metal of tin, and spleter

3946 Fine specimen of crystallised strontian, Scotland ; chalcedony, Cornwall; and cauk and fluor ${ }_{2}$ a polished spemen

3947 Undulated schistus, with pyrites, Hungary ; barytes, pearl spar on quartz, Hartz; and an undulated gypsum

3948 Two specimens of bevelled whitish fluor, two purple cubic fluors, one deep amethystine ditto, and a polished slab of ditto, Derbyshire

3949 Brilliant botryoidal marcasites, and a fine specimen of violet fluor, having the surface sprinkled with marcasites, Leicestershire

3950 Hamatitic iron ore, ditto; stalactitic, Triers; iridescent iron ore, from ditto; spathose iron ore, argillaceous ditto, and haekled quartz, Germany

3951 Calcareous stone, replete with green mica, Sicily; mica, with horn-blend imbedded, and a foliaceous mica, with quartz

3952 A slab of beautifully striated iridescent labrador feldspar, exquisitely diversified with azure, green, and gold

3953 Blend, finely crystallised on fluor, a large specimen, Cum. berland

3954 Manganese, finely crystallised, Illefeld

3955 A curions mass of crystallised galena and pyrites

3956 Red stellated needle antimony, Hungary; and grey crystallised antimony

3957 A large and handsome mass of finely coloured iridescent labrador feldspar

3958 Delicate moss-gold, on ferruginous quartz, Hungary

3959 Rose coloured manganese from Nagyac; and native gold on quartz

3960 Curious specimen of native gold, sprinkled on the surface of calcareous spar, and phosphorescent blend, Kapnic

End of the Thirty-third Day's Sale. 


\title{
THIRTY-FOURTH DAY.
}

\author{
Friday, the 13th of June, 1806.
}

3961 A Large specimen of quartz, crystallized

3962 Fasciculated white gypsum, Derbyshire; carbonate of barytes, polished specimen of cauk, undulated mica, and two more

3963 Twelve various specimens of marcasite

3964 Varicus crystallized tins, Cornwall

3965 Thirteen various vegetable impressions in small nodules of argillaceous iron

3966 A noble specimen of purple cubic fluor, in gigantic crystals and coated with minute white quartz crystals

3967 Actynolite in feldspar, carbonate of barytes, and two specimens of mica, one of them dendritical

3968 Native gold on brown quartz, brown pearl spar, galena with fluor, purple fluor, and five others

3969 Laminated mica, two short truncated hexagonal columns of mica, Moravia ; and an oriental garnet in its native state

3970 Fifteen vegetable impressions, chiefly ferns

3971 Two rich varieties of amethystine fluor, cut and polished, Derbyshire

3972 Aqua marine cubic fluors, coated with brilliant quartz crystals, Durham

3973 Yellow cubic fluors, a fine group, Derbyshire

3974 A very fine and delicate specimen of flos ferri, Germany

3975 Fossil nautilus, cast of an ammonite, and a ditto in pyrites

3976 A remarkably large fossil ammonite 
3977 Fourteen vegetable impressions of ferns

3978 An ammonite of large size

3979 Adularia in basalt, Hesse; and byalite, Franckfort

3980 Two specimens of native gold, bright red cinnabar, and crystallized carbonate of copper

3991 A fine specimen of shorlite, Altenburş; and a crystallized galena, Saxony

3982 Cross-stone, Saxony; rose-like gypsum, hæmatites in the matrix, and wood jaspar-all from Hesse

3983 Semi-orbicular marcasites on calcareous spar, a curious variety, England

3984 Cockscomb pyritical iron ore. Derbyshire; hæmatitic iron ore, and red ochre in calcareous spar; and solid hæmatitic iron ore, Lancashire

3985 A very large and fine specimen of rose-coloured arseniate of cobalt, partially crystallized in a mammillated form, with fortification cobalt, Hesse

3986 A large specimen of marcasite, Staffordshire; and a group of dog's tooth spar, in large crystals, Derbyshire

3987 Two handsome porcelain, and two earthen heads, Sic. of Turkish pipes

3988 Jasmine tube Turkish pipe

3989 Warrior's dress, River Gambia; with two ornamented pouches, and two parts of the Koran taken from the. crown of the king of Brach, in which they had been in-. closed by way of charm

3990 Twenty-eight casts of various medals, struck in commemoration of important events in Russia

3991 Rhombic spathose iron ore, combined with galena, white. nummular spar, \&c. Cumberland; septarium iron ore, Triers; cauliflower-like pyrites, on ectohnedral galena; and brown spathose iron ore

3992 A large specimen of solid marcasite, with a brilliant surface formed by innumerable: congeries of minute cubes; greatly intersected, Cornwall

3993 An extremely beautiful pair of ornamental fuor columns

3994 A large and remarkably well-executed piece of imitative penmanship, representing papers, \&c: of various kinds, lying in apparent disorder-framed and glazed

3995 A pair of beautiful purple fluor urns

3996 A group of flowers, \&c. represented in cut paper. The most uncommon accuracy anil taste are displayed in this highly admired work of ingenuity, which was the performance of Mrs. Graves, Sir Ashton Lever's sister.The whole elegantly framed, and glazed with plate glass

3997 A large specimen of marcasites, Ecton, Staffordshire; and. a contorted specimen of quartz crystallized with marcar sites 
3993 Salpa maxima, a fine specimen, in spirits

3999 Draco volans, in spirits

4000 Mya truncata with a singular adhesion, and a mactra with the animal

4001 Sabella penicillus with the animal, pholas dactylus of Pennant, with the animal, and a snake

4002 Nereis giganteus, aphordita aculeata, and the whale louse, with a piece of the skin of the whale

4003 Lophius histrix, or harlequin angler, two snakes, a lizard, and two more

4004 Anguis meleagris, pintado snake, and another curious specimen

4005 Fatus of the whale, curious

4006 Pike backed shark

4007 A curious labrus, a banded snake, and a lizard

4008 T'wo of the sucking fish, porcupine fish, a snake, and another

4009 Larvæ of exotic sphinges, and a snake, in two bottles

4010 A large parasitic crab, a scomber, and a small speckled lizard.

4011 Atherine fish, and another, two larvæ, and two small snakes

4012 Small salamander lizard, a frog, labrus, small snake, and another

4013 Six lined lizard, and three bottles containing small fish

4014 Exocœtus evolans, flying fish, Mediterranean

4015 A large specimen of scolopendra morsitans

4016 Cærulean snake, brown banded ditto, and another

4017 Mya arenaria, two specimens, in spirit

4015 Young of the piked back shark, with its oval attached, and a cuttle fish

4019 Brown balistes or old wife fish, and a snake

4020 Lacerta rufescens, greater scink

4021 A sucking or remora fish, and another

4022 Variotis shells of different genera

4023 The pink harp, Guinea; a hair streaked harp, China; three various patellæ, and a young leopard porcelain

4024 A large diadem echinus from the West Indies, and another from the English Coast

4025 The gray camp clam, Friendly Isles; the flame clam, China; a tortoiseshell harp, aud a young occidental argus porcelain

.4025 The tortoiseshell limpet, from Amboyna ; the star limpet, Cape of Cood Hope; and a radiated mask, Falkland's Island

4027 A'rare dialem echinus, with its spines, from Sicily; an echinus placenta, with six orifices, from Florida, and an unperforated cake echinus, $E_{\text {, Indies }}$ 
3028 Various shells of the buccinum, harpa, cuma, and other genera

4029 The bread basket clam, China; the crimson zoned pectunculus, New S. Wales; the garnet eyed limpet, and a striated fig

4030 A very large brown and red lance spined echinus, from $S t$. Mauritius, very scarce

4031 Two plieasant snakes, the butter whelk, a pied nerita, and two partridge's helmets

4032 Six congeries of ovaria, or spawn cases of shell fish; and a cluster of ditto, on a margaritifera shell

$4033 \Lambda$ fine venus's heart cockle, (cardium cardissa, Linn.) a map porcelain, with a fine orange mouth; and an arca tortuosa

4034 The satchel pinna, the royal mantle scollop, and a scarce vulsella, (Pedalium Perna, Soland.) all rare

4035 A large arca antiquata, S. Seas; a young brunette porcelain, a poached egg licium, and a tortoiseshell harp

4036 The great black pinna, South Seas, rare

4037 A beautiful clouded Persian crown melon, Amboyna, rare

4038 The margined tortoise, and another

4039 Elater bicellatus, buprestis ignita, several scarabæi, dytisci, \&c.

4040 Buprestis gigantea, carabus bimaculatus, var. and fifteen others

4041 Nineteen insects of the scarabæus, cetonia, and other genera

4042 Meloe proscarabæus, mylabris cichorei, several varieties, and a number of tenebriones, lampyrides, \&c.

4043 Twenty-seven insects, chiefly hymenopterous, including scolia fiavifrons, bimaculata, \&c.

4044 Three curious mantes; a phasma, and blatta

4045 Larva of a phasma viridis, and three other larvæ, and 2 mantis

\$046 Scarabæus Actæon

4047 Cancer ruricola, and another crab

4048 A large aculeated crab, Mediterranean

4049 Cancer lunaris, (matula fabr. and donov.) and a species of calappa ditto

4050 A small specimen of the imbricated turtle, testudo imbricata

4051 Cetonia hamata

4052 Phasma gigas, in the winged state, very rare

4053 Ditto in the wingless state.

4054 Pupa of mantis siccifolia, and a small mantis

4055 Scarabæus Hercules, a large and perfect specimen

4056 A large crab

4057 A tuberculated bears-ear crab 
4058 The thornback ray, in a glazed case

4059 Asterias caput medusæ of uncommon magnitude, and finely preserved

4060 Yellow-shouldered grossbeak

4061 Barnacle goose

4062 Green parrot, Brazils.

1063 Duck-tailed grebe, S. America

4064 Carrion vulture, Vultur aura

4065 Ginger-winged game cock

4066 Cinereous trogon, Trogan strigilatus

4067 Scarlet and blue maccaw

4068 Velvet-shouldered peacock, Japan

4069 Alexandrine parrakeet, and red-headed parrot, Brazils

4070 A large case containing a beautiful specimen of the pea. cock

4071 Swallow-tailed humming bird, Jamaica

4072 Shell duck, male

4073 Goosander, $\mathrm{m}$. and fem.

4074 Scarlet lory, E. Indies

4075 Hen and chickens, beautifully preserved

4076 The roller, Coracias garrula

4077 Blue jay, Corvus cristatus (without case)

4078 Bustard, fem.

4079 Scarlet ibis, tantalus ruber

4080 An uncommonly fine specimen the male bronze winged pigeon, (columba chalcoptera) and a female, New Holland

End of the Thirty-fourth Day's Sale. 


\section{THIRTY-FIFTH DAY.}

\section{Saturday; the 14th of June, 1806.}

$4081 \mathbb{M}$ AGPIE, a fine specimen

4082 Gambo goose

8083 A pair of the Alexandrine parroquet, Psittacus Alexandri

4084 Cape grosbeak, Loxia capensis, both sexes

4085 Spotted necked pigeon

4086 Scarlet-headed titmouse, a pair

4087 Orange-faced parroquet

4088 Ring ouzel

4089: Oriolus cristatus, crested oriole, Cayenne

4090 Red-wing thrush

4091 The flamingo, a young bird bred in Ostcrly Park

4092 Greater ani, crotophaga major-rare

40.93 Duck-tailec̀ grebe, America (without case) fine and rare

4094 Goshawk

4095 Pennantian parrot, both sexes, Botany Bay

4096 Hook-billed duck

4097 Rhamphastos lævirostris, smooth-billed toucan

4098 A fine specimen of tantalus loculator (without case)

4099 A large glass case containing the white peacock, pea hen, and young

4100 A ditto containing beautiful specimens of the pied peacock, hen and young

$\$ 101$ Certhia Sannio, mocking creeper, New Zealand-very rare 


\section{[35th day.]}

LEVERIAN MUSEUM.

4102 Black and white gull, America

4103 Bastard plover, tringa vanellus

4104 Ramphastos toco, the toco

4105 Turbit pigeon

4106 Strix hudsonia, the hawk owl, rare

4107 Whimbrel, or lesser curlew

4108 Crowned duck, America, a beautiful specimen

4109 . Picus varius, yellow-bellied woodpecker-a pair

4110 Duck-tailed grebe, one specimen, fine and rare

4111 Corvus scutatus, red-breasted crow, extremely rare

4112 Thirteen various specimens of vegetable impressions in argillaceous iron and coal slate

4113 A large mass of fossil palate bones of a fish

4114 Bones of fishes, four specimens and another

4115 Three fossil madrepores, and four other petrifactions

4116 Sundry petrifactions of teeth of fishes, bufonites, \&c.

4117 Parts of fishes, vertebral joints, and a fossil crab in marl, six specimens

4118 Belemnitx, and a section of an ammonite

4119 Seven various impressions of vegetables in iron, and coal slate

4120 Ancient English snuffers, and three others

4121 Three varions parts of Turkish pipes made of fine porcellain \&zc.

4122 A very handsome long Turkish pipe, ornamented with amber, \&c.

4123 Warriors dress, River Gambia, with a curious case made of a quadruped's hoof, and sundry ornaments

4124 Ornamented feather fly-flap, and a moorish dagger

4125 East Indian calendar, and 6 other virious specimens of oriental writing, \&x.

4126 A very superb fly flap, made of ostrich feathers, variously dyed

4127 Thirty-one casts of various medals struck in commemoration of important events in Russia

4128 Twenty-eight others

4129 Twenty-six others

4130 Twenty-five others

4131 Twenty-eight others. N.B. The whole are made' of a kind of basaltine ware

4132 Old English watch, and ten various others

4133 Large Roman brass lamp

4134 Two curious bronze figures

4135 Ancient Roman bronze figure of a tortoise, ditto of a child, .. $\quad \ldots$ and seven others various

4136 Two East Indian bronze figures, and a Roman ditto

4137 A handsome Turkish pipe, with the bowl formed of a cocoa nut, richly ornamented with silver 
4138 A capital Turkish carbine, richly inlaid with silver, late the property of the Hon. Wortley Montague

4139 The complete superb Turkish dress of the late Hon. Edward Wortley Montague, including a capital Damascus blade scimetar, and dagger

4140 A most elegant Turkish hooker, inlaid with silver, late the property of ditto

4141 A very elegant long Turkish pipe, richly ornamented with amber, lapis lazuli, \&c.

4142 A common flint of a light colour clouded with black, and broken asunder, the dark parts of which strikingly resemble a bird in the action of flying, Kent

4143 Two large specimens of crystallised quartz, Bristol

4144 Yellow quartz on purple fluor, light variegated flint, and pudding stone

1145 Large crystals of purple fiuor, imbedded in crystallised quartz, Derbyshire

4146 Flying squirrel, sciurus volans, Petromyzon fluviatilis, lepas anatifera, and two more in five bottles

4147 A sepia, a medusa, and two others

4148 Aplasia depilans, lepas anatifera, Petromyzon fluviatilis, and a gryllus gryllotalpa, in five bottles

4149 Brilliant octohædral marcasites, on slate, Cornwall; and spar with marcasites, Staffordshire

4150 Larva of some lepidopterous insect of uncommon magnitude

4151 A remora, a labrus obscurus, and another

4152 Centriscus scutatus, two of the Blennius genus, and one gasterosteus

4153 Aphrodita aculeata, a curious lepas, a cancer, and two others

4154 Three curious foetuses of a quadruped

4155 Gangetic crocodile, lacerta gangetica, a small specimen

4156 The variegated lizard, and another

4157 Two lizards of the gecko tribe and another lizard

4158 Small specimen of the sea turtle, and a land testudo

4159 A lizard of the gecko family, and another

4160 Purple cubic fuor, with marcasites coating the surface, and marcasites fram Ecton, Staifordshire

4161 Two mulberry trochi, two lineated pyræ, a butter whelk, and a black mulberry

4162 A thorny heart gryphus, naturally affixed to a blunt edged triplex, Martinique; cochlus singularis, New South Wales; the rugose sun, from Sicily, uncoated; and a South Sea snake

4163. The giant oyster, (Mytilus hyotis, Linn.) Friendly Isles, rare 
4164 A capital group of minutely crystallized quartz, on fitor, the surface studded with crystallized galena, Derbyshire

4165 The violet echinus, from China, very rare

4166 A large stalactite, and dog's tooth spar coating the inner surface of part of a large nodule, Gloucestershire

4167 A scarce white tower, Martinique; a rare fresh water shell. Cape of Goorl Hope; a clouded mitre, South Scas; a ferruginous mitre, and two others

4168 Fifteen various shells, among which are the undulated and painted alatæ, the freckled lunatus, and the green clouded trochulus, \&c.

4169 Mica, with horn-blende imbedded, Spain; and an undulated micaceous stone

4170 An ÆEtites or eagle stone, a hollow flint, with chalk or some other substance within it, Kent; and a piece of crystallized quartz, Bristol

4171 A small pinna, the old lady clam, the little harp, a young purple mouth frog, two iris elenchi, and six others

4172 A rare haliotis, from Luconia; and a beantiful zigzag pecten, Providence

$4173 \Lambda$ tortoise limpet, China; the great rayed mask, with adhesions of small balani, of a rare kind, Falkland Island; the violet trigonel, Tranquebar; and a solen strigilatus, Linn. Sicily

4174 Twelve small specimens of fluors, among which are, one shewing the modification of the octohedron, violet fluors several varieties, clear white fluor, \&c.

4175 Fourteen varieties of small diadem echini, some with their spines on; and an echinus placenta

4176 The huntsman cone, large and fine, South Seas; the beautiful cone, Guinea; and the peacock helmet, (Buc. granosum, Soland.) Senegal.

4177 The marygold limpet, the carved rhombus, haliotis argentea, K. George's Isle, S. Seas; a green mussel, and sixteen other rare small shells

4178 Twenty-four shells of different species, including an unicorn scoop, two staircases, ahe granulated and two other patellæ, a carved zebra trochus, \&c.

4179 The brown and red club spined echinus, St. Mauritius, very rare

4180 Conus grandis, Guinea, rare; and a Persian robe cuma, (Murex trapezium, Linn.)

4181 A large and fine violet ringed and stellated echinus having a double annulation, from China, very rare $5=5 \cdots$

4182 Quartz crystallized on galena, a large specimen

4183 Pearl spar finely crystallized on quartz crystals, and cauk sprinkled with yellow sulphuret of copper

4184 Four pleasing varieties of carbonate of lead 
4185 Piedra d'Ynca, and eight specimens of brilliant marcasite

4186 Three varieties of phosphate of lead, and one molybdate of ditto

4187 Slickensides galena, and five other specimens of galena

4188 Stellated gypsum in well formed crystals, on yellow gypsum, Sheppy

4189 Seven various volcanic productions from Mount Vesuvius

4190 A fine specimen of Spanish black chalk, penetrated by veins of amianthus

4191 A polished slab of Spanish avanturine

4192 A very large mass of galena weighing $293 \mathrm{lb}$, Derbyshire

4193 A ditto partially crystallized in very. large truncated cubes, and coated with calcareous drop stone spar, ditto

4194 Violet cubic fluor in very large and perfect crystals upon quartz, the surface of the fluor elegantly sprinkled with minute quartz crystals, Derbyshire

4195 Three varieties of selenite

4196. Noive gold very beautifully foliated, and somewhat.crys-

t tallized, Hungary

4197 A capital specimen of clear tabular barytes, from Westmoriand

4198 A large and very fine column of basaltes, from the Giant's Causway, Ireland. The specimen consists of five articulations

4199 A very large mass of white quartz crystals Cumberland

- $4200 \mathrm{~A}$ large and remarkably fine cubic marcasite, with a ferruginous coating, said to come from China. The same kind is brought from Peru, and is called by the Spaniards Piedra d'Ynca, or the royal stone. A specimen of this magnitude is very uncommon

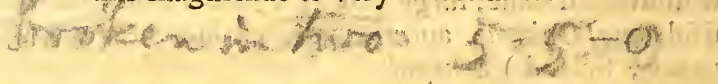

End of the Thirty-fifth Day. 


\title{
THIRTY-SIXTH DAY.
}

\author{
Monday, the 16th of June, 1806.
}

4201 - WO brass and two stone celts, and two Roman lamps

4202 Thumb screw, and two others

4203 Tile from the choir of Old Sarum; ancient English spear head, old almanack, \&c.

4204. Two ancient bronzes, and two earthen figures

4205 Nineteen various Roman instruments, \&c.

4206 A fine bronze figure of a negro

4207 Very large and perfect old English watch

4208 Remarkably large stone celt, a Roman lamp, a ditto lacrymatory, and ancient English spear head

4209 Celt, formed of beautiful green jaspar, another celt, three ancient English spear heads, and two others

4210 Tea pot and bason of curious wicker work

4211 Brown earthen ware tea pot, of very curious construction

4212 Ancient carved wooden cup, and two others

4213 Two antique marble heads to of

4214 Roman brass lamp, and seven various others

4215 Roman jug, two ditto platters, and another

4216. Variously colourcd glass jug, anno 1579

$421 \%$ Two pieces of hollow, green Delf ware, and a pair of spar flower pots $2-6$

4218 A very elegant white marble ditto $5-6$

4219 An ormament formed of steatite, and a small vessel of white marble 3 -

4220 Egyptian urn, inclosing bones of the ibis/f 
4221 A Roman jugg, an ancient earthern vessel containing bones. ('This was dug out of a barrow near Wantage, Berkshire,) and parts of Roman urns 3

4222 An elegant flat, white, marble ornament, and an ancient embossed dish

4223 Roman dish and cover, and six others-various /

4224 Flat Roman bottle, and an urn-shaped vessel -4

4225 Large Roman monumental stone

4226 Roman bötle found at Lincoln, and four others, three Roman and one old English $\ell=2-\infty$

4227 Five sundry ancient vessels $/ 0 ;-6$

4228 A handsome bronze East Indian pagod $3-15=0$

4229 An ancient figure of the Ephesian Diana, and five sundry Roman vessels

4230 A very large ancient vessel and stand, formed of brass, with the surface ornamentally engraved $1-1-10$

4231 Twelve various vegetable impressions in iron ore; and fossil wood

4232 Part of an asterias in chalk, parts of fossil crabs in marl, \&c.

4233 Anthropomorphitæ various, six specimens 15

4234 Fossil corals, belemnitæ, pectens, \&c.

4235 A mass of anomiæ imbedded in stone, a group of the cockscomb oyster, portions of nautili; \&c.

4236 Sundry petrifactions of bones, teeth, \&c. of fishes, \&c. 7 ?

4237 A variety of small ammonitæ and nautili

4238 Curious impression of part of a skeleton of a fish in black

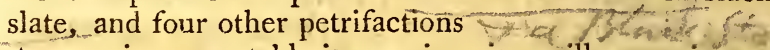

4239 Sixteen various vegetable impressions in argillaceous iron

4240 Whelk, Hordwell Olift; a tellina, two pectens, and several casts of ammonitæ 6.6 .

4241 Sundry fragments of fossil nautili, \&c.

4242 Vertebral. and other bones of fishes, two specimens, and other petrifactions $\&$

4243 Fourteen vegetable impressions of ferns, chiefly with their

counter parts
Jay, Corvus glandarius $5-6$

4245 Hobby, Falco Sulbuteo is

4246 Pacific parrot. Psittacus pacificus

4247 Guinea pintado, m. and fem.

4248 Common wild duck, m. fem. and young $/ 5 \div$

4249 Variegated lory, E: Indies $\rightarrow$

4250 Summer ducks bred in England, in. fem. young, and egg it- it

4251 Venerated kingsfisher. Alcedo venerata, m. and fem. very

rare $f-1,-\infty \mathrm{s}$

4252 Honey buzzard. Falco ativorus $1-7-0$
4253 Grous $t=7 ?$ 
4254 A most beautiful specimen of the Indian roller, Coracias Indica $4-4=0$

4255 Bittern

4256 Angola yellow parrot, Psittacus solstitialis, very fine and rate.

4257 Common woodcock, $\mathrm{m}$. and fem.

4258 Turtle dóve, $\mathrm{m}$. and fem. Kent

4259 Ring pheasant (in mahogany case)

4260 A case, containing 15 specimens of ruffs and reeves $\mathrm{cll}$ -

(-2) riously preserved in various attitudes, Tringa pugnax

4261 Nightingale.

4262 Goldfinch, $\mathrm{m}$. and fem. and missel thrush

4263. Sanderlin, m. fem. and young $1-1=3$.

4264 Osprey, Falco halicetus

4265 Long-eared owl, Strix otus

4266 Cape Hoopoe, Upupa promerops $1,0,6$, Aिt

4267 Cornish chough, Corvus graculus

4268 Red-breasted tanager, Tanagra jacupa

4269 Avosetta

4270 Parrot-billed grosbeak, Loxia Psittacea-very rare 1/1 $12-0$

4271 Greater spotted woodpecker, m. and fem. Picus major $-2-0$

42,2 A fine specimen of Paradisea apoda $1-4-0$

4273 White spoonbill, Platalca leucorodia $2,2-0$

4274, A beautiful specimen of the ultramine thrush, Ampelis cotinga

4275 Buprestis sternucornis, fascicularis, elater lineatus, and $a$ variety of smaller insects

4276 Tenebrio gigas, meloe autumnalis, lampyris bicolor, and various others, thirty-three $/ 4-C$

4277 Tettigonia atrata, nepa rustica, and several of the locusta genus

4278 Tettigonia picta, sirex gigas, gryllus roseus, and fourteen others

4279 Buprestis ocellata, elater ocellata, and various smaller species of the elater genus $10-6$

4280 Meloe proscarabæus, eight locustæ and grylli, and a small cerambyx $1-6$

4281 Gryllus campestris, several of the locust genus, leptura; staphylinus, \&c. altogether twenty-seven

282 Twenty-six various insects, chiefly apes.

4283 Papilio Menelaus, a beautiful specimen $f-p$

4284 Nepa grandis, scolopendra morsitans, blatta heteroclita, altogether seven

4285 Fulgora lanternaria, or great lantern carrier; Surinam 4286 The thorny gryphus, Martinique, the pied spondylus, China; and a rare gryphus, Pulo condore $t$

4287 Brilliant minute marcasites, coating the surface of spathose A 3 
iron ore and white quartz crystals, and solid crystallised marcasite, England

4288 Resin-coloured tin, and five other specimens, Cornwall /

4289 A small diadem echinus with its spines, a mammillated ditto, four other diadem echini, and three echini placentæ io

4290 The flame clam, the toothed pyrum (Bucc. odontites, Soland.) a striated fig, a pear limpet and five others $2-6$

4291 Brilliant bubbled marcasites, marcasites on quartz crystals, and another coating fluor $10-3$

4292 A capital group of cubic fluor, of a yellow mottled and amethystine colour, on cubic galena, Durham

4293 The tulip cone, the long-beaked buccinum; the nodulated clam, the unicorn's and gazelle's horn needles, and thirteen others $2-6$

4294 The marbled senectus, partly uncoated, China; and the painted tun, N.S. Wales $7=1-0$

4295 Two violet-mouth olives, two varieties of the proteus olive, a pomegranate sea snail, and a black music

4296 An occidental argus porcelain, a deformed ditto in a young. state, the smooth European clam, a brunette cockle, and two others $3-6$

4297 Cream coloured tabular barytes, ditto with pyrites, brown rhombic barytes on blend and mica

4298 Bright green felspar from Siberia, a fine specimen and rare

4299 A nodule of mica, with white actynolite from Moravia; green felspar, Siberia ; and mica in a calcareous matrix, forming a spurious avanturine, from the side of Mount Etna

4300 Polished slab of brown and white selenite, Germany; and quartz crystals, sprinkled with laminated calcareous spar

4301 The brown star limpet, an arca fusca, the waved alatus, a South Sea snake, a dice cone, and fifteen others

4302 Sulphate of strontian in well-defined crystals, Bristol

4303 Twenty-six curious small shells, some of them rare, among which are the painted ermine and friar cones, the flaming cuma, the lineated obelisk, the brindled pupa, \&rc.

4304 The purple oyster, New South Wales; another scarce purple oyster, Friendly Islands; and an orange-coloured gryphus

4305 Brilliant cubic marcasites, and marcasites on yellow fluor with galena

4306 The bumped distaff shell, from the South Seas, very scarce

4307. A very large and fine conus pulicarius, Otaheite; the stair-, case of extraordinary magnitude, Tranquebar; and a scarce species of brocaded cone, Ceylon $1-17$ to

4308 Purple fluor, with marcasites on the surface, cockcomb marcasites, bubbled ditto, and another 
4309 Double-pointed quartz crystals on iron ore, Bristol; argillaceous iron ore, and iron ore, Triers-

4310 Tellina Spengleri, Linn. the lesser camp clam, the banded variety of the painted powter alatus, a quaker olive, the violet rayed solen, two spotted thorny woodcocks, and three others

4311 The camp clam (Venus castrensis, Linn.) the painted clam, from China; and two varieties of a rare clouded fig, from Florida-all fine $\quad 6=6$, ? 3

4312 A very large fool's cap limpet (patellu ungarica, Linn.) Sicily; the white-streaked brown ark, from Pulo Condore; and the beauty limpet, Cape of Good Hope

4313 Pectunculus bifida, the strawberry cockle, the netted porcelain, the glassy placuna, a noah's ark, and eight other shells

4314 Two of the plaited mitre, and a scarce banded mitre, all from China

4315 A resplendent map-like variety of the iridescent labrador feldspar, in which ultramarine and golden orange predominate

4316 Calcareous spar, an elegant group, beautifully sprinkled on the surface with pyrites, Cumberland

4317 A specimen of native foliated gold, the surface exhibiting dendritical appearances, Hungary

4318 A small crystal of basalt with olivin, Hesse; hyalite, Franckfort; a.singular marble; and wood jaspar.

4319 The purple club-spined echinus, St. Mauritius - very rare 4320 The red variety of the furbelowed clamp, from Amboyna, rare; and two large and fine brunette porcellanx, from the South Seas

End of the Thirty-sixth Day's Sale. 


\title{
THIRTY-SEVENTH DAY.
}

\author{
Tuesday, the 17 th of June, 1806.
}

4321 A Brass and two stone celts, and another

4322 Two Roman lamps, and a curious celt

4323 Roman brass lamp; and four others

4324 Part of a bronze figure, from Herculaneum; a bronze leg. an arm, and another

4325 Three Roman lamps, and a lachrymatory

4326 Two ancient bronze figures, and a marble terminus

4327 Nine ancient and foreign rings, and two others

4328 Two large copper monastic seals - 6

4329 Square silver rupee of the Emperor Acbar ; three ancient coins, and five other Roman antiquities $/ 2$

4330 Two ancient bronze figures $7-C_{0}$

4331 Large stone celt, another, and two Roman lamps

4332 Curious and perfect old English silver watch

4333 Old English silver thimble, ditto silver ring, two rings, and another

4334 A Roman bulla of fine gold

4335 Two curious ancient bronze figures

4336 Ancient Roman Seal, and nine other various antiquities

4337 Sixteen various ditto $/ 3$

4338 Two pieces of hollow green ornamented delf

4339 Small ancient bust, small vessel of white marble, and another $/ \infty$ i $*$ )

4340 Six sundry Roman vessels 
4341 Large and remarkably curious embossed dish, with fish, shells, \&c. in high relief on the surface

4342 Scarlet and yellow feather cloak, black and scarlet ditto, two necklaces, and a dagger, Sandwich Isiands.

4343 Specimen of the nett work. which forms the ground of the feather cloaks, with bunches of the feathers

4344. Three various fly-flaps, and a tabooing wand, fiom ditto

4345 Leg ornament of shells, four playing bowls, and false hair from ditto.

4346 Dancing rattle, cordage, and sundry fish hooks, fiom ditta

4347 Very large shark's tooth instrument, from ditto $-1,2$

4348 Boar's tusk bracelet, and four various necklaces, from ditto

4349 . Two basaltine mirrors, large roll of cordage, large and small fish-hooks, from ditto 1 the $a$,

4350 Feather cap, dagger, tabooing wand, and two fly-flaps, from ditto

4351 Small scarlet feather cloak, brown ditto, yellowy ditto, and five feather necklacs, from ditto

4352 Fine variegated net work for a cloak, with bunches of the feathers, and a fly-flap

4353 A very handsome fly-flap formed of tropic bird, and other feathers affixed to the bone of a human arm. This

4354 Specimen of the bread fruit, being the only one brotgigt

2 over by Capt. Cook; and a specimen from Dominica

4355 Curiously carved spontoon, New Zealand

4356 Large idol carved out of the solid woad, King Georges Sound

4357 Spear, Owyhee; ditto Ngotka Sound; and bow, Friendly Islands

4358. Fly-flap with carved handle, large fish hook, comb, and tattooing instrument, Otaheite

4359. Patapatoo made of whalebone, sleeping stool, a flaxen and. another petticoat and cloth, South Seas:

4360 Fine flaxen cloak with a handsome border, New Zealand; and matting, New Amsterdam

4361 Very large sleeping stool, Qtaheite; matting and a petticoat, S. Seas

4362 Tw o large pieces of matting, S. Seas

4363 A large and handsome green nephritic stone adze, New Zealand

'4364. Cocoa nut cordage, an adze, fish skin file, two fish hooks; sc. S. Seas

4365 Nephritic stone ornament, fly-flap, and eight sundry instruments, S. Seas

4366 Nose flute, mauth flute, syrinx, and two others, Otaheite -

4367 Large and handsome sling, and three others, from ditto

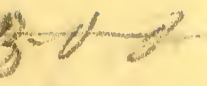 article is particularly described by $M r$. Samwell in his "narrative of the death of Capt. Cook."


4368 Model of a canoe, a whistle, three carved ornaments, \&c. and a comb

4369 Fly-flap, with a zigzag handle, nephritic stone chisel, and five others

4370 A curious large carved vessel, ornamented with pearly eyes; and a singular club-like instrument

4371 Various head and neck ornaments, from Marquesas, S. Seas

4372 Four various baskets, from the S. Sea Island

4373 A beautiful feather gorget, from the Friendly Islands

4374 Papilio Bolina, Machaon, \&c. eight specimens

4375 Six ditto, including Midimus, Antiope, \&c.

4376 Gryllus pictus, Cayenne, rare, Truxalis nasutus, locustæ, grylli, \&c.

4377 Gryllus morbillosus, China; and various other grylli, and locustæ

4378 A large and singular locust

4379 Gryllus dux, pupa of morbillosus, gryllotalpa, and another.

4380 Papilio almana, leucothoe, \&zc. ten specimens

4381 Papilio Machaon, Antiope, Paris, \&c. eleven

4382 Nine butterflies as Lemonias, Paris pyrophus, \&c.

4383 Six ditto various

4384 Eleven ditto, including Enone, Pasiphæ, the Camberwell beauty, \&c.

4385 A large spiny crab of the Parthenope family

4386 Long-clawed shrimp, ocypode vocator, and four others

4387 A curious squilla, (Cancer Linn.)

4388 Cancer pictus, muricatus, and three others

4389 Cancer mantis, Linn. and two scorpions

4390 Cancer mantis, Linn. and five small crabs

4391 A very large shrimp, Cancer Linn.

4392 Papilio Machaon, Alope, Jatropha, Hyperanthus Pyrrhus, \&c. fifteen specimens

4393 Five butterflies, various, among which are papilio Penthesilea, a pair

4394 A large tuberculated bear's ear crab, (scylarius Don.)

4395 Three butterflies

4396 Papilio Glaucippe, Eneas, and another

4397 Papilio Teucer, \&c. four specimens

4398 Papilio Menelaus, a beautiful specimen

4399 Papilio Glaucippe, Agamernnon, and four more

4400 Ten insects of the bombylius and asilius genera

4401 Scarabreus Mydas

4402 Aranea maculata Fabr.

4403 Scorpio afer, and another, a tarantula spider, and a phalangium

4404 Papilio Orion, Delia, Iris, var, and five others

4405 Papilio Heliacon, rure 
4406 Cockscomb marcasite, two varieties, brilliant bubbled marcasite, and another

4407 Rock ouzel, m. and fem.

4408 Thrush variety

4409 Bald coot

4410 Mottled variety of the common crow

4411 Common buzzard, Falco buteo

4412 King bird of Paradise, Paradisea regin, very fine and rare, without case

4413 Rook variety

4414 Preacher toucan, Ramphastos picatus

4415 Capital tanager, Tanagra capitalis, very rare

4416 Blend in small crystals, with pearl spar, Cumberland; cauk polished, Derbyshire; and mammillated pearl spar, with fluor, Cumberland

4416 Six specimens of copper among which are yellow sulphuret with opaque chalcedony, Cornwall; malachite in sand stone, two specimens, Durham ; peacock copper, \&c.

4417 Three specimens of carbonate of lead, galena, with copper ore, and two others

4418 An ÆEtites, with two kernels; Scotch fortification agate, three other agates, and two more

4419 Native copper, Cornwall; yellow ditto, Anglesea; and another, Sweden

4420 Light-coloured violet fluor, dark yellow ditto, dark violet ditto, Derbyshire; and part of a large cube of violet fluor, encrusted with white quartz crystals, Durham

4421 Six specimens of copper, among which are blue malachite, crystallised, Siberia; needle-like copper, Jamaica; and anil four others

4422 Mineralized wood, with copper, and native moss-like copper on quartz, Cornwall; and another

4423 Four specimens of marcasite, one coating dog's tooth spar, and another cubic fluor intermixed with galena

4424 Water rail, a pair

4425 Red shank, male and female

4426 Pintail duck, Anas acuta

4427 Stannel Hawk

4428 Curlew, Russia

4429 Pink-headed green parroquet, a beautiful pair

4430 A pair of the wryneck, Yunx torquilla

4431 Loxia oryx, grenadier grosbeak, Cape

4432 Carrier pigcon, male and female

4433 Turdus cyanurus, Brazils, very fine and rare

4434 Tabuan parrot, Psittacus tabuanus

4435 Strix fuliginosa, Hudson's Bay, fine and rare

4436 A noble specimen of fine plumbago or graphite in the matrix, from Cumberland 
4437 A highly beautiful calcareous deposition, tinged with the most brilliant regal purple, from the cobalt mines of Hesse-very rare

4438 Specimen of cobaltic mine stone, having a bright yellow sparry surface which is variegated by singularly fine purplish cobaltic dendritæ, from Hesse-extremely rare

4439 A very fine specimen of pharmacolite, or mammillated white arsenical ore, on a cobaltic ore, from Hesse-very rare

4440 A most noble specimen of the compact black oxyd of cobalt, from Hesse, very fine and rare

End of the Thirty-seventh Day's Sale, 


\title{
THIRTY-EIGHTH DAY.
}

\author{
Wednesday, the 18th of June, 1806.
}

1441 F OUL weather cloak, New Zealand; baked earthen bottle, New Amsterdam; and a fly-flap

4442 Meerschaum pipe, and four other foreign pipes

4443 Small model of a snow sledge, with the snow shoes, \&c. three curious pipes, Siberian comb, an East Indian poisoned dart, and three others

1444 A curious hour glass, ornamented with mother of pearl; a consecrated candle, from Loretto; and another

4445 Light green nephritic stone ornament, a fly flap, and sundry instruments, South Seas

4446 Curious fabricated petticoat, New Amsterdam; a syrinx, a nose flute, and two others, Otaheite

4447 Nephritic stone needle and chissels New Zealand; and eight sundry others, S. Seas

4448 Five curious pipes, and pipe tubes, and sundry others

4449 A short match-lock gun

4450 Sundry curious horse shoes

4451 Nine pieces of iron, being part of the tire and other iron work of a waggon which was laden with gunpowder, and blew up at Talk on the Hill, Staffordshire

4452 Four various Scuth Sea clubs

4453 Patapatoo, basaltic adze, and a pagee, Friendly Islands

4454 A very finely carved long war club, from ditto

455 An original deed of grant signed by the celebrated William Penn; a letter written by Hephzibah Parker, who was 
deprived of sight, by small pox; a specimen of lead perforated by insects; and a fac-simile of a letter written by Oliver Cromwel

4456 Seven curious copper coins, finely preserved

4457 A fine copper medallion of Montesquieu; a ditto of Washington; two silyer papal coins, and six others, various

4458 A large and fine silver medallion, and a large copper coin of Queen Christina

4459 Twelve various coins, from St. Iago

4460 Ninc: various modern tokens and coins, (one with a silver case) and a medalion of the enslaved negro

4461 Seven early British and other coins

4462 A fine enamel miniature of Oliver Cromwell

4463 A Queen Ann's farthing in very fine preservation

4464 Eight various insects, including buprestis punctatis, and Lethrus Aeneus, Botany Bay

4465 Papilio Machaon, Claudius, Hyparete, and thirteen other insects

4466 Gryllus flavicornis, China; morbillosus, roseus, \&c.

4467 Papilio Levana, Rhamni, Huntera, and fifteen others

4468 Papilio Leucothoe, Assimilis, \&c twelve specimens

4469 Papilio Feronia, Lemonias, \&c. fifteen ditto

4470 Phalæna tau, both sexes, russula, several coleopterous and hemipterous insects, \&c. eighteen

4471 Gryllus migratorius var. flavicornis, nasutus, and other grylli, twelve specimens

4472 Papilio Fidia, Dirce, Midimus, '\&c. nine

4473 Papilio Orion, and two more butterflies

4474 Papilio Gilippus, Orythia, Cardui, \&c. nine

4475 Golden-eye duck

4476 Psittacus variegatus, variagated lory, East Indies

4477 Silky fow's, a pair, East Indies

4478 Bald pigeons, a pair, Canada

4479 Snow bunting

4480 Red-winged oriole, Oriolus Phœniceus

4481 Common wren, with nest and young

4482 Land rail, male and female, with their young

4483 Ring-tail, Falco pygargus

4484 White owl, Strix flammea

4485 Paradise Jacamar, Alcedo Paradisca, a pair

4486 Spcckled goose, Cape of Good Hope

4487 Common teal, a pair

4488 Shoveler duck, male and female

4489 Curious variety of the magpie

4490 Scoter duck, a pair

4491 Carunculated chatterer, Ampelis carunculata, very rare and. fine

4492 Turdus iliacus, redwing, a pair 
4493 Scarlet ibis tantalus ruber, a fine specimen, withont case

4494 Drumming partridge, America

4495 Cuckow

4496 Largest sanderling

4497 Striated hawk, Jamaica

4498 Variety of the snipe, and the grey godwit

4499 Orange-fronted parrotuet

4500 Pine grosbeak, a pair

4501 Red chatterer, Ampelis Carnifex, loth sexes

4502 Mercury pigeon

4503 Cape king-fisher, Alcedo capensis

4504 The common kite

4505 Turdus torquatus, the ring ouzel, with the young

4506. Blue-bellied parrot, Psittacus hæmatodus

4507 A pair of the common pigeon

4508 Supercilious king-fisher, Alcedo superciliosa

4509 Great horned owl, Strix Bubo

4510 Red and blue maccaw, Psittacus Macao

4511 Aracari toucan, ramphastos aracari

4512 White-headed dove, Jamaica

4513 Purple grakle, Gracula quiscula, mas et fem. Jamaica

4514 Purple capped lory, East Indies, Psittacus domicella.

4515 Acarus cancriformis, tarantula spider, and four others

4516 Hippobosca Avicularia, cancriform spinous spider, and several others, with four of the asilus genus, sixteen specimens

4517 Two curious scorpions

4518 Aranea brunnea, a large specimen

4519 Papilio Orion, Delia, and a curious Phalæna

4520 Papilio Liberia, Atalanta, Passiflora, and four more

4521 Smooth-plated bear's-ear crab, Scyllarus Fabr.

4522 Cancer mantis, and a scorpion

4523 A tuberculated crab, ocypode vocans, crabs, shrimps, \&c. eleven specimens

4524 Cancer mantis, a small bear's ear, and other crabs, onisci, \&xc. sixteen specimens

4525 Cancer latipes, several onisci, scolopendra morsitans, \&c. various

4526 Sculopendra Morsitans of a large size; rattle of a rattle snake, Hippocampus, and eight other specimens

4527 Papilio Paris, Turnus, Midamus, \&c. eight specimens

4528 Ten various of the genus mantis

4529 A large crab of the Portunus genus Don.

1530 Draco volans, flying dragon, Hippocampus, larva of Phalæna Cossus, \&c.

4531. Papilio Leilus, a fine pair, and another papilio

4532 A variety of larvæ, scolopendræ, small snake, \&c.

4533 Aranea avicularia, the bird catching spider 
4534 Scolopendra morsitans, a large specimen, various spiders, \&c.

4535 Sunciry larvæ of insects, an hippocampus, \&c.

4536 A scorpion of very large size, Africa

4537 An elegant specimen of pharmacolite, with deep red arseniate of cobalt, Hesse ; solid ruby silver, Hartz ; applegreen zeolite, Palatinate ; and crystallized gypsum, Germany

4538 A small specimen very rich in native silver, Potosi, fortification cobalt, with pink and yellow oxyd, Hesse; beautifully crystallized vitreous silver, with solid malachite, Siberia; glanzerde, Hesse; pharmacolite, ditto; and manganese, Germany.

4539 A very fine specimen of copper nickel, with green oxyd of ditto, in barytes, Hesse

4540 Three varieties of cobalt, Hesse; and an auriferous pyrites, Hungary

4541 Fine whitish cubic fluor, with the edges somewhat bevelled, and sprinkled with minute calcareous crystals and blende; amethystine cubic fluor, and very dark ditto, Derbyshire

$4542 \Lambda$ very fine specimen of dendritical copper nickel, Hesserare

4543 A large and very fine specimen of silvery calcareous earth, or glanzerde, in an argillaceous matrix, Hesse

4544 A very fine and large specimen of hyalite, from Franckfort

4545 Crystallized grey cobalt, Saxony; golden-coloured pearl spar, Hungary; byalite, Franckfort; and cinnabar, Idria

4546 A fine and large specimen of grey cobalt, with copper nickel, in heavy spar, Hesse

4547 Three varieties of cinnabar, Idria; and a good specimen of grey partly rlecomposed cobalt, with arseniate of ditto, frorn Hesse

4548 Rose-coloured calcareous spar, in primitive rhombs, Hesse; fortification cobalt, ditto crystallized zeolite in basalt, ditto; and grey gold, Transilvania

4549 Elegantly mottled cubic violet fluor, Durham; violet ditto, beautifully sprinkled with minute quartz crystals, whitish cubic ditto, and dark purple ditto, Derby

4550 Crystallized calamine, Hesse; brilliant grey cobalt, with copper nickel, ditto; pink calcareous deposition, ditto; hyalite; Franckfort

4551 Crystallized grey cobalt, Hesse ; and crystallized cinnabar, Idria

4552 Red crystallized oxyd of chrome, Siberia; and crystallized arseniate of cobalt, Saxony 
4553 A delicate specimen of capillary pharmacolite, Hesse; and hæmatites iron, Germany

4554 Two specimens of cinuabar, one with native vermillion, Idria ; purple calcareous deposition, Hesse, rare; and brilliant piated iron ore, Elba

4555 Two very large specimens, one of semi-fossillized wood, Hesse; the other asbestos, N. America

4556 Three elegant varieties of arseniate of copper, and green fluor in octohædral crystals, Cornwall

4557 Arseniate of copper, a fine specimen of chalcedony, Cornwall; and octohædral fluor, ditto

4558 Mispickel, Germany; a very elegant specimen of arseniate of copper, Cornwall; a ditto of octohædral fluor, and crystallized fahlerz, with resin blende, Hungary

4559 A fine mass of grey argentiferous copper, elegantly variegated with crystallized green and blue malachite, from the Hartz

1560 A fine specimen of calamine, with iron ochre, having on its surface several beautifully defined crystals of sulphate of lead, Hesse--rare

Eind of the Thirty-eighth Day's Sale. 


\section{THIRTY-NINTH DAY.}

\section{Thursday, the 19 th of June, 1806.}

4561 TrO fringed petticoats, and another, S. Seas 4562 Two large and handsome pieces of matting, from ditto

4563 Two petticoats, and a sleeping stool, from ditto 4564 A fine impression of Bartalozzi's print of Omialu the Otaheitan

4565 Fish decoy, and ten other implements of the South Sea Islanders

4566 Large fish skin file, fly flap, cocoa nut cordage, \&c. S.

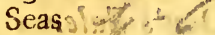

$4567 \Lambda$ brass, and four other curious foreign pipes $/ /$

4568 Three various clubs, from the South Sea Islands $/ /-$

4569 A basaltic adze, a pagee, a patapatoo, and a war club, from ditto

4570 Green nephritic stone, and a large variety of implements, of the S. Sea Islanders

4571 Eight curious foreign pipes, and six sundries //

4572 A curious club, New Caledonia

4573 Ornamented paddle, Friendly Islands

4574 Leg ornament made of shells, and four bowls for playing with 5

4575 Curiousiy carved halbert, New Zealand $\langle-\rangle=0$

4576 Two single and a double headed idol, from Sandwich Islands

4577 A singular figure carved in stone, an oriental pipe, and seven sundries 
4578 A representation of engraving, ingeniously executed in composition 6

4579 A nose flute, Otaheite; a club and ancther

4580 An ornamented mouth flute, from New Zealand; and a nose flute, Otaheite

4581 New Zealand fishing net, weighted with coral

4582 Two curious large baskets, from the Friendly Islands

4583 Ancient purse; ditto metallic bottle, a singular wooden ditto, and a large iron French medal

4584 Twelve sundry Roman antiquities

4585 Thirteen ditto $(-3-3$

4586 Four curious ditto - 10

4587 A curious ancient ornament of fine gold, \&c.

$4588 \mathrm{~A}$ small carving of a horse in steatite

4589 A very curious old English watch, in an ornamented small clock case, made anno $1542 /-/ 3$ -

4590 Three Roman lamps, a lachrymatory, and two celts

4591 Two handsome small Persian-ware plates 2 - 15 .

4592 A curious small glazed bottle, with metallic handles - 8 -

4593 Fifteen various old English, and modern foreign pipes and pipe heads $10-$

4594 A very elegant small Japan waiter $/-4=0$

4595 A tea equipage, and a standish curiously formed of serpentine stone.

4596 Thirty-five beautiful small shells, among which are the undulated and ringed porcellanæ, two varieties of the ridged pupa, the notched neretoidea, of New Zealand, \&ce.

4597 A variety of patellæ, arcæ, pectunculi, and other shells, natives of the British Isles

4,598 A green fluted dentalium, various species of the serpula, and teredo genera, two alatx, two needles, and other shells $3-\mathrm{Z}$

4599 The honeycomb, leopard, and brunette porcelannæ, the studded ark, from China; a scarce white pectunculus, and a strawberry cockle

1600 An internal portion of a nautilus pompilius, tellina scobinata, the striped bronze limpet, a small spondylus, a tulip mussel, four pectunculi; and eleven other shells

4601 A beautiful undulated young leopard porcelain, large map porcelain, and an African parasol limpet, all fine 18

4602 The white basket clam, from China; a tortoiseshell harp, Mudagascar; pecten sagrinata, W. Indies; and a cock'swing clam

4603 The chequered ear, New Zeuland; the painted ear, Cape. of Good Hope ; a notched bull's eye breast snai!, China; and a prince's mantle scallop, Friendly Islands. 
4604 Three varieties of mitra sanguisuga, two striated spotted needles, and a singular ladder, all from China, and rare 4605 The painted purpura, Guinea; the crown of thorns cas14 sidula, Ceylon; a wax taper cone, and a mosaic cone

4606 A mammillated diadem echinus, New South Wales; a diadem echinus, with its spines, from Sicily; and an echinus esculentus, English coast

4607 The great flat-spined strombus, from China; the great S. Sea strombus, loth of them in a young state, and a large dark-coloured Chinese harp

4608 A scarce lucerna, W. Indies; the chesnut land snail, Jamaica; two large and fine lapwing's egg bullæ, from China

4609 A large six-holed echinus placenta, a purple shield echinus, and a diadem echinus

4610 A fine tridachna ursina, or bear's paw clamp, from the 18 E. Indies

4611 A large and fine spider strombus, Madagascar

4612 The violet echinus, from China, very rare 2

4613 Scaup duck, m. and fem.

4614 Red-legged partridge, $m$. and fem.

4615 Curasso bird, Crax alector

4616 Honey buzzard, Falco apivorus

4617 Ox-eye titmouse, a pair, and a pair of the goldfinch

1618 Certhia carulea, blue creeper

4619 Summer duck, male

4620 Corvus corax

4621. Psittacus ararauna, in mahogany glazed case

4622 Soland goose

4623 The common kite

4624 Common crossbill, Loxia curvirostra, three specimens 8 .

4625 Ampelis cayana, very fine / -

4626 Rook variety $/ 0$ is

4627 Handsome variety of the partridge, in glazed mahogany case

4628 A large case, containing the common cuckow in its various stages of growth, with the respective birds by which $i$ is fed

4629 The common partridge, m. ferm. and seyenteen young, most beautifully preserved

4630 . Hobby, m. fem. and young, Falco subbuteo 2080

4631 The black bird of paradise, Paradisea superba, very grare

4632 A large spider, bombylius, acarus cancriformis

4633 Papilio passitiora, Liberia, Atalanta, and five more

4634 Papilio Almana, Chrysippus, and two more 6

1635 A great variety of moths and butterflies

4636 Papilio Cato, var. and two others

4637 Ten butterflies, inciuding Papilio Passiflora 
4638 A large tarantula, and six smaller spiders $5-6$

4639 Papilio Almana, Delia, Orythia, \&zc.-nine specimens

4640 Papilio Bolina, Varanes, and nine other specimens

4641 A large number of insects of the Phalæna and Papilio tribes among which are Papilio Sesia, Orythia, \&c.

4642 Twenty-two Papiliones, chiefly Danai candidi

4643 Papilio Panope, Viola, Leucippe, \&c. - twenty-five specimens

4644 Cimex Aurauticus, Cerambyx sericens, Curculio pulverulentus, Nepa rustica, Chrysis Amethystinus, and thirty other insects of different genera

4645 A fine specimen of flexible quartz

4646 A small species of Palinurus Don. allied to Cancer Homárus Linn.

4647 Plumbago in the natrix, Cumberland; and quartz crystals exhibiting impressions of cubical fluor, the surface of which it formerly coated

1648 Sundry larvæ, \&c. of jnsects, rattles of the rattlesnake, a scorpion, \&c.

4649 A very large hippocampus, and another smaller, reniform phalangium, spiders, \&c. a curious larva

4650 Aranea avicularia, birḍ-catching spider, Surinam

4651 Flesh-coloured barytes, with pearl spar and pyrites, Hartz; and two others, black chalk with amianthus, from Spain; ; selenite and quarry store, Ireland 2 . "L.

4652 Crystallized brown lead ore, phosphate of lead, galena with copper ore, and three other galenas $/ 4 \%$

46.53 A large group of tetrahædral blend, on yellow cubic fluor, Derbyshire

4654 Amethystine fluor in large cubes, Durham

4655 A rhomboidal fragment of rich azure-blue labrador feldspar, another specimen of labrador having hornblend attached, and a third reflecting green and purple $-2=6$.

4656 A pebble-shaped fine Spanish avanturine $/ 7-$

4657 Clear tabular crystallised barytes, Cumberland

4658 A nodule of brown mica, surrounded with white actinolite, an hexagonal short columnar crystal of inica, and a laminated mica; Moravia $/-3-0$

4659 Arseniate of iron and copper, three specimens, and yellow copper with amianthus

4660 Crystallized cinnabar, with running quicksilver, Idria

4661 Crystallized sulphate of strontian, Bristol; yellow barytes in plates, and flesh-coloured tabular barytes, sprinkled with mundic

1662 Carbonate of barytes on blende, large specimen of calcareous spar, and three various crystallized blendes 
4663 A fine polished specimen of dark green asbestos, a ligneous asbestos, and an amiantbus

4664 Octohædral marcasites, solid marcasites, cockscomb marcasite, and marcasites coating slate, from a quarry near Dublin

4665 Marcasites on coal, ditto in breccia, from Staffordshire, and a polished slab of fluor

4666 Large and interesting cut specimen of fossilized wood, in which the ligneous structure is perfectly well preserved, Hesse -1

4667 A large and very fine specimen of dendritical nickle, Hesse; very rare

4668 Part of a stratum of steel-grained cobalt, Hesse ; fortification cobalt, ditto; and light red cinnabar, Idria ${ }^{2}$.

4669 Fine specimen of violet cubic fluor, partially covered with pearl spar, Durham; greenish-grey cubic ditto, amethystine ditto, in fine cubes, and another exhibiting the fracture

4670 Mesnilite in the matrix, from Montmartre, France; polished cauk, and two specimens of mica $10-7$

4671 Delicate pink arseniate of cobalt, coating the upper surface of a fortification cobalt, Hesse; and red quartz crystals, Bristol

4672 Crystals of lepidolite in white quartz, Moravia; bright green zeolite, Palatinate (cut and polished); porphyrylike nodule, containing in its cavity, quartz crystals, with a bright feruginous coating, Germany

4673 Beautiful onachine cornelian, red and white Oriental mocha, and a small agate, bearing the resemblance of a head $t=6-\infty$

4674 Very fine Oriental mocha, beautiful orange-coloured cornelian, and än orange ditto

4675 Lepidolite, and a short truncated hexagonal column of mica, both from Moravia

4676 An elegant specimen of light bluish green calcareous deposition, finely coloured by the oxya of nickel, from the cobalt mines of Hesse

$\$ 677$ A handsome specimen of foliated native gold, Hungary $/ 9$

4678 A most superb and large specimen of mammillated rosccoloured arseniate of cobalt, on a ferruginons matrix, Hesse

4679 Large and very fine specimen of mammillated iron ore,

9 the surface exhibiting a brilliant golden gloss, Germany

4680 A noble specimen of tellurium, or aurum-graphicum is

End of the Thirty-ninth Day. 


\section{FORTIETH DAY.}

Friday, the 20th of June, 1806.

$4681]$ HE ticket No. 34,119, which gained the Museum in the Leverian Lottery, and a letter from Hyder Ally

4682 Pipe cases, three foreign pipes, and various sundries

4683 A beautiful Persian ware plate, and three Turkish pipe heads

4634 Specimens of Mosaic, from the ceiling of Santo Sophia, at Constantinople; two other pieces of Mosaic, various amulets, \&c.

4685 A curiously ornamented box made of steatite

$4686 \mathrm{~A}$ very handsome and curious ancient incense vessel

4687 Calcareous incrustation on a large bird's nest and eggs

4688 Ketton stone, Gloucestershire, strontian, Bristol ; and carbonate of barytes, Lancashire

4689 A fine specimen of globose carbonate of barytes, on blende; and a crystallized blende, on cauk

4690 A slab of brown wood-like cauk, Derbyshire

4691 Beautiful dendritical marcasite, on slate, from Essex; and brilliant marcasites, coating yellowish or ferruginous quartz

1692. A large specimen of variegated cauk, formed into an ornament, Derbyshire

4693 Blend, on pearl spar, two specimens ; mica, Spain; yellow fluor, with cauk, Durham; Spanish avanturine, and gypsum, Derbyshire

4694 A large calcareous deposition, and a fine quartz crystal, coated with micaceous iron ore 
4695 Toad-stone, Switzerland; undulated copper-coloured schis. tus; and minute garnets in the matrix

4690 Asphaltum, Dead Sea ; and a large polished specimen of cannel coal

4697 Carbonate of barytes in well-defined crystals, mica, dendritical ditto, Estramadura, and another

4695 A congeries of clear white selenites in long prisms, on a gypseous stone, Matlock

4699 Bubbled copper ore, with finely coloured surface, Devil's kitchen, Cornwall ; purplé fluor, and another

4700 Large and very fine specimen of looking-glass cobalt, Hesse

4701 A beautiful group of violet fluor, having the surface partially sprinkled with brilliant marcasites, in small cubes

4702 Very finely crystallized specimen of sulphate of strontian, Bristol

4703 Two large specimens of stalactitic and hæmatitic iron ore, and a bubbled iron ore, with red ochre, Germany

4704 Mammillated cank on galena, with clear cubic fluor; gypsum, Sheppey; sulphate of strontian, Bristol; two specimens of barytes, and one more

4705 A garnet limpet, the grey trumpet, a yellow mouth alatus, the spctted pectunculus, a South Sea sun, and nine others

4706 Schiller spar, small amber-coloured garnets in the matrix, and dark mica in the matrix

4707 The brown brindled apiculum, Arabia; Solen abreviatus, a scarce triplex, arca fuscata, the pottle pyrum, the cancellated trochlea, Sicily; the coach road whelk, New Zealand; and six others

4 708 Pale violet cubic fluor, delicately sprinkled with marcasites, Derbyshire

4709 Mica finely crystallised in hexagonal plates, Bohemia

4, 10 A large stalactite and group of dog's-tooth spar

4711 A fine specimen of plumbago in the matrix

4712 The cock's wing and painted clams, the long-beaked fig, Tellina fausta, Solard. W. Indies; the rugose sun, Bay of Naples; two hair-streaked harps, a strawberry cockle, and an archipelago whelk

4713 Blend and pearl spar, sprinkled on the surface of a large mass of crystallized quartz, Cumberland

4714 The painted powter, the chesnut uber, mytilus angulatus, the furbelowed pyrum of Nootka Sound; and seven other shells

4; 15 The thorny heart gryphus, (Chama arcinella, Linn.) naturally affixed to a cancellated Pectunculus, from Martinique; one valve of a rare ark, New S. Wales; and a young brunette porcellain 
4716 The emerald cochlus, uncoated; the proteus, and three other cones; the yellow variety of gryphus bicolor, a strawberry cockle, and eight other shells

4717 A scarce variety of the muricated trumpet, China; and a distorted American fig

4718 A young leopard porcelain, a remarkable variety of an old shell of the same species, and a parasol limpet

4719 Tellina virgata, Linn. a young leopard porcellain, two purple oysters on a limpet, Nerw $S$. Wales; scarce banded breast snail, and five others

4720 The boat crypta, the girded and another oriental pyrum, the carved rhombus, the painted clam, two futed mytili, and six other shells

4721 The bat volute, uncommonly large, from Ceylon

4722 A large and fine furbelowed clamp, (Chama gigas, Linn.) from Borneo

4723 Fasciculated white gypsum, with pearl spar, a large specimen, Derbyshire

4724 Six coppers, namely malachite, copper in schistus, Scotland; arseniate, Cornwall; and smelted copper, \&c.

4725 Two large groups of dog's tooth spar, Derbyshire

4726 Plumbago in the matrix, Cumberland; and wood perforated by teredines and fossillised, Sheppy

$4 \nmid 27$ A very large and capital specimen of stalactitical iron ore, Triers

4728 A large crystal of deep purple fluor, formed on a beautiful mass of dark brown pearl spar, Derbyshire

4729 The sulcated and striated green dentalia, two of the clephant's tusk Dentalium; the retort, and several other species of serpula, three portions of the furbelowed watering pot, the purple.rayed, short, and slender solens and two needle shells

4\%30 Tellina Pensylvanica, (Venus Pensylvanica, Linn.) pectunculus scriptus, a beaded trochulus, New Zealand; the mutable olive, the black cat's mouth nerita, a tuberculated ear, and fourteen other shells

4731 Two pink harps, two beauty limpets, the white duck's-bill patella, the shagreened lithophagus, the black hound's ear margaritifera, an occidental vulsella, and the Spengler tellen

4732 A beautiful map porcelain, Amboyna; a large panther porcelain, Aralia; and a painted clam, from China-all fine

4733 A variety of beautiful small shells, some of them rare

4734 The tortoise limpet, from Amboyna; the gorgon limpet, Barbary; and the leopard porcelain, in its first stage of growth-all fine 
4735 The long clamp, with fine foliations, and two large and fine leopard porcellanæ, from Madagascar

4736 Sulphate of strontian, Bristol, serpentine cut and polished Cornwail, and selenite

4737 A specimen of the Dartford warbler, Motacilla provincialis -without case

4738 Tabular barytes on galena, sulphate of strontian, Bristol; and cauk, with minute calcareous spars

4739 Cross-bill jackdaw

4740 Fasciated grosbeak, Loxia fasciata

4741 Blie variety of feldspar, magnesian spar, and barytes

4742 Loxia curvirostra, cross-bills, three specimens

4743 Blue creeper, certhia cærulea, without case

4744 White spoonbill, Platalea leucorodia

4745 Summer duck, male

4746 Lace pigeon, a fine pair

4747 Pompadour-fronted parroquet, South Seas, in fine plumage

4748 Otaheitan blue parroquet, Psittacus taitanus, very fine and rare

4749 Raven

4750 Hook-billed creeper, Certhia olscura, very rare

4751 Magnificent bird of Paradise, fine and rare

4752 Congeries of selenite, clear white crystals, Derbyshire; and tabular barytes, coated with pyrites in brilliant small crystals

4753 Papilio Chrysippus, Almana, and six other butterflies

4754 Papilio Viola, Rhamni, and eighteen others

4755 Tabular barytes, very finely crystallised, Cumberland

4756 Papilio Aurora, rare, Passifiora, Orythia, and a great variety of the phalæna tribe

4757 Papilio Leucippe, Hyparete, \&c. twenty specimens

4758 Mutilla Americanus, Buprestis variabilis, New Holland, and a variety of apes, formicæ, \&c.

4759 Lamia vermicularia, Don. New Holland; Mutilla Americana, and a number of the Oestrus, Musca, and Tipula genera

4760 Thirty-cight insects of the musca genus, and Tenebrio viridis

4761 Scolopendra morsitans, various tabani, Asilii, \&c.

4762 Scarabrus Actæon

4763 Buprestis vittata, China; Cerambyx sericeus, Africa; Cetonia punctata, India; and a variety of Cicindelæ, Nepæ, Carabi, \&c.

4764 Scarabæus Mimas, Tettigonia Atrata, Cimex Phasianus, and various Cicindelæ, Musca, \&c.

4765 Papilio Orythia, Leucippe, Horta, Comma, Sc. twentyfour specimens 
4706 Scolia flavifrous, Cicada lanata, Cerambyces, Cicindela Germanica, \&zc.

4767 Curculio gigas, various Scarabæi, Sphex tropica, stc.

4768 Scarabæus Mimas, bicornis, Dytiscus marginatus, and other insects

4769 Cancer mantis, Linn: Pagurus, shrimp, scorpion, and another

4770 Papilio Turnus, Paris, and four others

4771 A variety of lnsects of the Mantis genus

4772 Papilio Almana, Cardui, Oenone, Antiopa, \&c.-twelve specimens

4773 Papilio Huntera, Lemonias, Cardui, \&c.

4774 Twelve various Papiliones-fourteen specimens

4775 Papilio Ulysses, in fine condition, very rare

$4776 \mathrm{~A}$ box made of red Hertfordshire pudding stone

4777 Large brown rock crystal, said to be impregnated with tin, Bohemia

4778 A large quartz crystal, Cornwall; and a broad pointed crystal, Cheshire

4779 Pearl spar on crystallized quartz, and another on galena

4780 Copper, on fossil madrepore, a malachite, yellow copper with white chalcedony, and another, Cornwall

4781 A most beautiful specimen of the King Paradise bird, $P R$ radisea regia, extremely fine and rare

4782 Red headed duck

4783 Red bellied trogon, Trogon curucui

4784 A very fine specimen of the rock manakin, Pipra rupicola

4785 Leverian trogon, Trogon Leverinus, extremely fine and rare

4786 A large and fine group of brown stalactitical spar, having a cauliflower-like surface, Matlock, Bath

1787 A capital gromp of purple cubic fluor upon white quartz, the whole overspreading the surface of two gigantic crystals of purple fluor, Durham

4788 A grand specimen of purple cubic fluor, having the surface of the crystals sprinkled with minute crystals of galena

4789 A fine specimen of native orpiment in the matrix

4790 Two good varieties of crystallized blend, and a carbonate of barytes

4791 Six coppers, as malachite Cornwall, sulphuret on compact brown blend, \&c.

4792 Reddish quartz crystal, purple fluor, Derbyshire; white crystallized quartz, and another

4793 Plumbago in the matrix, Cumberland; and a large piece. of dog's tooth spar, Derbyshire

4794 Pointed calcareous spar, enclosing pyrites in the crystals, a large specimen 
4795 Very brilliant cubic marcasites on lenticular spar, and galena, Cumberland

4796 A slab of iridescent feldspar. The whole mass of which is variegated with gold and azure-a superb specimen

4797 Native gold, crystallized, Hungary

4798 Venetian talc. Asphaltum; green ligneous asbestos; white asbestos on the matrix, Corsica; and elastic bitumen

4799 Native gold in cubic pyrites, Siberia-remarkably scarce

4500 An uncommonly large and fine specimen of flexible quartz from the Brazils, 31 inches long l:y 19 broad. This specimen which is singularly thin, exhibits the flexible quality in a very striking manner

Find of the Fortieth Day's Sale. 


\section{catalogue}

OF THE

cris $+1,9$

\section{LEVERIAN MUSEUM,}

\section{Wrata? ? ? ?}

\section{PART VI.}

g

zwly bru

\section{SEVENTEEN DAYS SALE.}

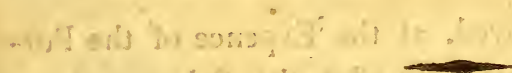

in ins

The seven Parts of the Catalogue (Price 7s.6d.) to be had at the Museum; at Messrs. King and Lochée's, (the Auctioneers) and at Hayden's Printung Oifice, Brydges Street. Covent Garden.

Hayden, Prieter, 4, Brydges Street, Covent Garden. 


\section{CONDITIONS OF SALE.}

I. THE highest Bidder will be declared the Buyer; but if any Dispute should arise, the Lot must be put up again.

11. No Advance less than Sixpence; above One Pound One Shilling; above Five Pounds, Five Shil LINGS.

III. Every Purchaser is to pay down Five Shillings in the Pound, as Earnest, in Part of Payment, and give in his Name and Place of Abode, if required.

IV. The Lots to be removed, at the Expence of the Purchasers, within one Day after the Sale; and the Remainder of the Purchase-Money to be paid on or before the Delivery.

V. Upon Failure of complying with the above Conditions, the Money deposited in Part of Payment shall be forfeited. All Lots uncleared within the Time aforesaid, shall be re-sold, oy public or private Sale; and the Deficiency (if any) attenaing such Re-sale, shall be made good by the Defaulters a this Sale.

Gentlemen who cannot attend the Sale, may have their Commissions faithfully executed, by their humble Servants, 


\section{FORTY-FIRST DAY.}

saturday, the 21st of June, 1806.

4801 BASALTIC adze, and two clubs, from the S. Sea Islands

4802 A pagee, and a patapatoo, from ditto

4803 A quiver of African arrows

4804 A ditto of barbed Persian ditto

4805 A singular iron arrow, found on the scite of the Castle of Harwood, Yorkshire

4806 A curious foreign bow and arrows

4807 A singular tomahawk, from Lagoon Bay, on the coast of Africa

4808 An ancient shield and sword

4809 Gambado spurs, and three Old English ditto

4810 A sword, having a pistol connected with the handle

4811 Persian sword in an ornamented scabbard

4812 Tomahawk, and saw in one

4813 A moorish criest, and a large knife

4814 Sword, with carved ivory handle

4815 Mourish criest, with ornamented handle

4816 A true Toledo sword

4817 Highland basket-hilted sword

4818 Two swords

4819 A very curious club, from New Caledonia, the head of it. being formed out of the thick part of a very large shell

4 S20 Elegantly carved club

1821 Guinea pintado, $m$, and fem. 
4822 Guillemut, with its eggs

4823 Rose-hill parrot, Psiltacus eximius

4824 Gadwall duck, $m$. and fem.

4825 Dottrel, $m$. and fem.

482.6 Common pheasant, $m$. fem. and young

4827 Common duck, and 7 young

4828 A most beautiful specimen of the Columba nicoliarica, very rare

4829 Missel thrush, $m$. and fem. Turdus viscivorus

4830 Embroidered merops, New Holland, rare *

4831 Stock dove, $m$. and fem.

4832 Hamatopus Ostralegus, $m$. and fem.

4833 Psittacus Alexandri

4834 Com̌̀mon magpie, most beautifully preserved

4835 A fine specimen of the peacock (without case)

4836 Falco Domingius

4937 A capital specimen of the scarlet ibis, Tantalus Ilis

4838 Black-backed gull, m. and fem.

4839 Grey plover, $m$. and fens:

A840 Painted finch

4841 Lesser cockatoo, (without case)

4842 Capuchin pigeon, $\mathrm{m}$. and fem.

4843 Trumpeter pigeon, m. and fem.

4844 Dartford warbler, Motacilla Provincialis, without case

4845 Powter pigeon, $\mathrm{m}$. and fem.

4846 Jackdaw variety

4847 Golden Paradise bird, Paradisea aurea, extremely fine and rare

4848 Common goatsucker

4849 Common snipe, m. fem. and young

4850 A most capital specimen of the marble pheasant, Persia, extremely rare

4851 Two small land tortoises

4852 A small specimen of the sea turtle

4853 A land tortoise

4854 Jesuit's cap Asterias, extremely rare

4855 The mince-pye star fish

4856 Five-rayed granulated star fish

4857 Asterias placenta, thirteen-rayed star fish, and four others

4858 A curious and very uncommon species of asterias

4859 Slender-spined porcupine fish, and another, curious

4860 Twelve preserved specimens of American fishes

4861 Singular tuberculated ray fish, East Indies

4862 Gar fish, in a glazed case

4863 Portugese man of war, a species of Holothuria

4864 Polypus, Mediterranean

4865 Round sun fish of a large size

4866 Oblong sun fish ditto 
4867 Five-rayed granulated star fish, and four others

4868 Ostracion punctatus, holly fish, in fine preservation

4869 Green balistes fish

4870 A large thorny crab, Mediterranean

4871 Eyes of the whale, and a small polypus

4872 Spiny parrot fish, Jamaica, in excellent condition

4873 An uncommonly fine specimen of the green speckled file-fish

4874 Two small fishes, in glazed cases

4875 A small specimen of the sturgeon

4876 Skeleton head of the porpoise

4877 Specimen of the painted short-clawed lobster

4878 Spinous crab, in a glazed case

4879 The kite gurnard fish, and another, in two cases

4880 The acarauna fish, and two others ditto

4881 A small toad fish angler

4882 The great gar fish

4883 A large remora, or sucking fish

4884 A gigantic specimen of the common lobster

4885 Ditto of still more extraordinary size

4886 Trunk fish

4887 The trout

4888 Silurus

4889 Balance shark

4890 Trumpet fish

4891 The common porpoise

4892 Parts of a lobster of enormous size

4893 Saw of a small saw fish, a porcupine fish, and a balistes

4994 John Dory fish

4895 Gold and silver fish

4896. Swallow-tailed file fish, North America

4897 Two small sturgeons, blue shark, and a suching fish

4898 Variegated file fish, St. Helena

4899 Striped wrasse, Labrus variegatus, larger pipe fish, and two more.

4900 The flying fish, father lasher, porcupine fish, \&c. twelve specimens

4901 Sundry odd valves of the arca, pectunculus, ostrea, gryphus, and other genera of bivalves, \&cc.

4902 A great variety of shells of the porcellana, nerita, patella, bulla, and other genera

4903 The leopard porcelain; the brunette porcelain, and a small bear's paw clamp

4904 The pitch solen, from Newfoundland; the spotted thorny woodcock triplex, five porcellanæ, the abreviated solen, and thirteen other shells

4905 Two coronated cassidulæ; the lesser silk brocade cone, two of lunatus monile, two other lunati, and two alata -all rare 
4906 Sundry curious small shells of different genera

4907 Two small spotted melons, China; the flame clam, from same place; a young brindled alatus, Antigua; the pink harp, Guinea; and a rayed mask, Straits of Magellan

4908 Two varieties of the painted clam, China; two of the purple oriental gryphus, the purple indented oyster, and a carnp clam

4909 A variety of beautiful small shells of different genera, some of them rare

4910 The palid buccinum, sicily; the scarlet-mouth buccinum, Asia; Tellina variabilis, Guernsey; and three other shells

4911 A scarce pectunculus, allied to Venus Gallina, Linn. from New S. Wales; a singular variety of the mole-hill porcelain, the sardonyx porcelain; and a tortoiseshell harp

4912 Sundry odd valves of the placura, cepa, and gryphus genera, and a variety of opercula, or doors of shells

4913 The granulated patella, Cape of Good Hope; a striped bronze limpet, New Caledonia; the great radiated mask, Falkland Islands; a large carnelion porcellana, a dissected harp, and one other

4914 A variety of shells of the nerita, oliva, trochus, patella, and other genera

4915 Two chersinæ, the pied nerita of Ascension Island; a staircase, and sundry other shells

4916 Mytilus discors of New Zealand; two small harps, the pink-mouth powter alatus, the painted powter alatus, the painted powter, and various other shells

4917 Arca tortuosa, Tranquelar; the undulated pectunculus, same place; and the faintly sulcated glycemeris, West Indies-all rare

4918 Two beautiful oriental argus porcellanæ, and a large uncoated pink and yellow'shield clam, all fine

4919 A fine bear's paw clamp, having its folinitions very protuberant, and otherwise complete, from Amboyna

4920 The sattin limpet, South Seas, extremely scarce; and the beauty and brown star patellæ, from the Cape of Good. Hope

End of the Forty-first Day's Sale. 


\section{FORTY-SECOND DAY.}

Monday, the 23rd of June, 1806.

4921 CoMMON Dobchick, m. and fem.

4922 Virginian nightingale, Loxia cardinalis, fem.

4923 Common hoopae

4924 Dusky grebe, rare

4925 Partridge, m. and fem.

4926 Hen harrier hawk

4927 Caprimulgus maximus

4928 Rook variety

4929 Wagel gull

4930 Red godwit, m. and fem.

4931 Nutcracker, Corvus caryocatactes, one specimen, without case

4932 Rock ouzel, m. and fem.

4933 Golden-crested swallow-tailed butcher bird, S. Americn

4934 Picus viridis, m. and fem.

4935 Magellanic penguin

4936 Tipped grebe, Colymbus urinator, Geneva

4937 Lace Pigeon

4938 Certhia Senegalensis, extremely fine, m. and fem.

4939 Bald coot, $m$. and fem.

4940 Buff-breasted goosander

4941 Gray parrot.

4942 White sheath bill, Vaginalis Australis, very fine and extremely rare

4943 Merlin hawk, Falco esalon 
4944 Lesser cockatoo

4945 Blue-headed parrot, Africa

4946 Recurvirostris avocetta

4947 Fasciculated bee-eater, Merops fasciculatus

4948 Gold pheasant, fem.

4949 A very fine specimen of the Columba coronata

4950 Anas Gambensis, spur-winged goose, S. America-extremely rare and fine

4951 Sea turtle, a small specimen

4952 A singular and rare species of asterias, or star fish

4953 A large specimen of the mince-pye star fish

4954 Three star fish

4955 Jesuit's cap star fish, extremely rare and fine

4956 Nine species of asterias, various

4957 Ten-rayed star fish

4958 Two curious star fish, West Indies; and three small

4959 Two curious species of ostracion, or trunk fish

4960 Tetrodon lagocephalus, and the porcupine fish

4961 Two curious varieties of the porcupine fish, and another

4962 Asterias saput Medusæ

4963 Two granulated star fish

4964 A capital specimen of the mince-pye star fish

4965 Long armed sepia, in a case

4966 A. fine and large specimen of the wolf fish

4967 Large head of the logger-headed turtle

1968 Parts of two gigantic claws of the lobster

4969 Two species of ostracion, and another fish

4970 Sting ray, and a small globe diodon

4971 Balistes vetula, and a bicornuted Ostracion

$4972 \mathrm{~A}$ tortoise, and triangular trunk fish

4973 Head of a fish, the porcupine globe fish, and blunt-headed cachalot

4974 A small torpedo

4975 Lump sucker, cyclopterus lumpus

4976 A fine specimen of the flying kite fish, and another fying fish

4977 Large hare globe fish, and triangular trunk fish

4978 A large sucking fish or remora

4979 Angel shark

4980 Small wolf fish

4981 King crab, Monoculus Polyphemus

4982 Gymnotus electricus, electrical eel, rare

4983 Thorny crab

4984 Gurnard

4985 Unicorn fish, Acanthurus unicornis, extremely scarce

4986 Spotted file fish

4987 Three of the Monocilus Polyphemus

4988 Dog fish, or spotted shark, and an old wife fish 
4989 Unicorn toad fish, and two other fish 4990 Spotted porcupine fish, Jamaica

4991 The common turtle

4992 Thornback ray, and the smooth spotted ray

4993 Marine lamprey

4994 Toad lophius, and another fish

4995 Astacus fluviatilis, several specimens, in two cases

4996 Angel, or carauna fish

4997 The common turbot

4998 Father lasher, America

4999 Raja Rhinobatos

5000 Land tortoise, North America.

5001 Squalus Pristis

5092 The dolphin of the Portuguese

5003 Picked backed shark

5004 Triangular fish, head of woll fish, porcupine fish, and two more

5005 Pristis microdon, supposed to be unique

5006. Triangular trunk fish of large size

5007 A large shell of the turtle

5008 'The wolf-fish, a large specimen

5009 Spotted globe fish

5010 Brown shark, Jamaica

5011 A select collection of British birds eggs, with a few of those belonging to the larger aquatic species

5012 Nests of the esculent sea swallow of China, and six other curious nests

5013 The nest and egg of a small species of humming bird-a highly interesting article; and a sample of the web of a large spider inhabiting the West Indies, in which, the humming bird is sometimes found entangled

5014 Calcareous incrustation, on a large birds nest and eggs

5015 The yellow bulb (Bulla rapa, Linn.) Tranquebar; the white streaked ark, from Pulo Condore; the grey camp clam, Friendly Isles; and the pink harp, Guiner

5016 A rare clouded cockle, from Haynam; mactra striatula, Linn. Tranquebar; and four others.

5017 A large arca nox, with adhesions of gryphi; West. Indies; and two large and fine porcellanæe

5018. The flame clam, the orange gryphus, a rufous spondylus, a large carnelian parcellana, and three other shells

5019 The green fluted, and the green striated dentalium, solen plebeius, the long beaked trumpet, a tubulated balanus the orange mouth buccinum, Guinea; and eight other shells

5020. A small long furbelowed clamp, the wheatsheaf and another scarce patella, two rare ears from the South Seas, two iron mould porcellanæ, and two other curious shells. 
5021 Two painted powters, China; solen vagina, Tranquelar; two of the little harp, Madagascar; three staircases, and various other shells

5022 A purple magillanic mussel, polished; the golden auricula limpet, New South Wales; the conic bronze patella, Falkland Island; and thirteen other shells

5023 The scallop edge Venus's heart, (cardium cardissa, Linn.) two others of the same genus, a cock's wing clam, a. Noah's ark, two painted clams, and two patellæ

5024 The radiated cuma, China; alatus dentatus, ditto; the mop buccinum, rare; two scarce fringed triplices; porcellana ochracea, Sicily; a very young clouded Persian crown, the oyster-like slipper, and nine other shells

5025 The cock's wing clam, (Venus gallina, Linn.) from Ceya lon; the ridged ear, Cape of Good Hope; the flame and painted pectunculi, and two others

5026 A variety of shells of different genera

5027 Two varieties of lunatus monile, the little argus or sieve porcelain, two of the pottle pyrum, the pink mouth horse chesnut, the scabrous porcellana, several of the balanus on an ear, Guinea; the slender solen, and twen. ty-one other shells

5028 Mactra plicataria, Linn. from Tranquebar; two fine varieties of the panther porcelain, from Arabia; and a rare clam, (Venus dilatata, Soland.) from Florida

5029 Two very young spotted melons, the painted powter alatus, the knitted cardium, an occidental sun, and four other shells

5030 Several varieties of the moth and brindled pectens, a small aculeated pectunculus, (Venus Dione, Linn.) and sundry other bivalve shells, in all twenty-one

5031 The lesser camp pectunculus, the denticulated Venus's heart cardium, the fairy cone, and a vulsella, from China; the furbelowed pyrum, Nootha Sound; a purple pecten, New South Wales; and three other shells

5032 An arca Noæ, the granulated and three other patellæ; an egg cockle, the rugged sun, uncoated; an uncoated snake, and thirteen other shells

5033 The mary-gold, and granulated patellæ, the spotted trapezium, (Chama calyculata, Linn.) a scarce trochus, the white rose tellen, (Tellina divaricata, Linn.) a rare cardium, and three others, China

5034 The pimpled porcellana, the grey dactylus, the striped cuneus, a vice-admiral cone, a distorted lynx porcelain, the hair-streaked cuma, the sinuated auricula limpet, the dotted lunatus, and sixteen other shells

5035 The pellucid triangular serpula, on an anomia, Minorca; two violet-moutb porcupines, the pavement helmet, the 
pied neritæ of Ascension Island; the white shagreen pecten, $W$. Indies; and nine others

5036 Two of the brown tower, Tranquebar ; the pallid lunatus, the beauty limpet, the cinereous buccinum, two scarletmonth trumpets, and four others

5037 The white-riyed brown ark, China; two yolk of egg breast snails, Haynam; the American bull's-eye snail, the brindled cochlus, and pectunculus bifida-the three first rare

5038 A young brunette porcelain, a sardonyx ditto, and a beautiful small bear's paw clamp

5039 The bread-basket clam, (Venus fimbriata, Linn.) the splendid clam, (Venus splendens, Soland.) and a rure clouded variety of the lettered clam, Venus literata, l,inn.-all from Asia

5040 Lithophagus digitatus, two of the slender and a short solen, two scarce mactræ, Tellina carnaria, Linn. two of the chama trapezia, Linn. Solen fragilis, Soland, and six other rare shells

End of the Forty-second Day's Sale. 


\section{FORTY-THIRD DAY.}

Thesdly, the 24th of June, 1806.

$5041 \mathrm{~A}$ Roman earthen lamp, two stone celts, and an ancient British spear head

5042 Nine sundry Roman antiques

5043 A small bronze figure, and seven other various antiquities

5044 Four very handsome Turkish pipe bowls or heads

5045 A curious japan snuff box, and an elegant circular box formed of red hardened steatite

5046 A smelling bottle beantifully carved in steatite, and three curious foreign pipe heads

5017 Nine sundry Roman antiguities

5048 Seventeen ditto

5049 A small carved head, from the Cave of Elephanta

5050 A brass celt, and two stone ditto

5051 A remarkably straight and handsome piece of bamboo

5052 Walking stick, made out of a plank belonging to one of the floating batteries destroyed before Gibraitar; and a long stick made of rhinosceros skin

5053 Large portion of an elephant's tusk

5054 Double tusk of an elephant, and a specimen of dark coloured ivory

5055 Remarkably large tusk of a sea cow

5056 Various fishing and other implements, Otaheite; and a beautiful feather necklace, Sandwich Islands

5057 A large scrateher made of bone, and sundry other curiosities, S. Sea Islands

5058 Large nose flute, a syrinx, and roll of cocoa nut cordage, from Otaheite 
$5059 \mathrm{~A}$ " quiver of poisoned darts, in use among the original natives of the Leeward Islands, who blow them through a hollow tube ten feet long. A monkey wounded by one of them falls down dead within one minute. In the wars of the Indians, if a prisoner be taken having any of these darts, he is instantly put to death.",

5060 Marten, $\mathrm{m}$. and fem.

5061 Large grey squirrel, N. America

5062 White var. of the rat

5063 A very fine specimen of Felis pardalis, rave

5064 Largest weasel, and large water rat

5065 Otter, N. America

5066 Viverra putorius, N. America

5067 Long-tailed field mouse, ditto variety, and a water shrewthree cases

5068 Radiated mole, N. America

5069 Black squirrel, N. America

5070 Flying squirrel, and a curious foreign rat

5071 Grey var. of the common hare

5072 A beautiful specimen of the common otter

5073 Mus Capensis

5074 Long-tailed field mouse, water shrew, and water rat-three cases

5075 Leverian fossane, rare

5076 A fine specimen of the Patagonian cavy, extremely rare, Cavia Patagonica

5077 Dusky acanthurus, fasciated chætodon, a balistes, and another, collected by Capt. Cook in the Indian Seas

5078 Acanthurus lineatus, very rare, and two other fishes, ditto

5079 A collection of eggs of the simaller British birds, among which are several rare species

5080 Several of the hanging birds nests suspended from the leaves of a palm

5081 Ruffe or pope, burbot, flying fish, and a gurnard

5082 Rough ray, or skate

5083 A noble specimen of asterias aurasiaca

5084 A singular granulated star fish

5085 Tuberculated asterias, rare

5086 The thornback, preserved in a glazed case

5087 Large and perfect specimen of asterias caput Medusæ

5088 Seven curious preserved fishes, America

5089 A very rare slender rayed asterias, and five more

5090 Six preserved fishes, America

5091 Nineteen ditto, from America

5092 The mince-pye star-fish of large size

5093 Four specimens of asterias

5094 Ostracion auritus, eared trunk fish, Pacific Ocean-extremely rare 
5095 Two horned ostracion, and ancther fish of the same genus 5096 Balistes monoceros, ostracion bicornutus, and anothe:

5097 A variety of curious seed vessels, \&c.

5098 Fifteen various skins of fishes, America

5099 Ostracion pictus, Pacific Ocean, rare; and another

5100 Hare globe fish, Carolina

5101 The common salmon, out of season

5102 The bream, and three other dried fishes

5108 A most capital specimen of the largest spirey asterias

5104 Three dried fishes, the turbot, barbel, and another

5105 A snake, and curious fruit in two bottles

5106 Saphirine gurnard, and a snake

5107 Black chin grebe, fem. rare

5108 Colymbus cornutus, horned grebe, rare

5109 Colymbus glacialis

5110 Goosander, fem.

5111 Shear water

5112 Shell duck

5113 Black-toed gull, rare

5114 Missel thrush

5115 Ancient auk, extremely rare

5116 Sparrow hawk

5117 Black guillimot, Colymbus grylla, without case

5118 White variety of common partridge

5119 Nightingale, $\mathrm{m}$. and fem.

5120 Red lark, extremely rare

5121 White fronted parrot

5122 Hen harrier hawk

5123 Loxia cardinális, mas.

5124 Red godwit, $m$. and fem. in mahogany case

5125 A very fine specimen of the Cornish chough, Corvus grat culus

5126 The nut-cracker, Corvus caryocatactes

5127 Ardéa equinoctialis

5128 Young barn owls, two specimens

5129 Fire-eyed grebe, $\mathrm{m}$. and fem.

5130 Crested auk, Alca cirliata, rare

5131 Lesser goosander, fem.

5132 Psittacus Nestor, S. Seas, rare

5133 A fine specimen of the crested humming bird, on the nest

5134 Red godwit.

5135 Phasianus pictus

5136 Cowrie bird, Africa, Loxia punctalaria, Linn.

5137 Goshaw, N. America

5138 The white jer falcon, Falcojer fulco, rare

5139 A capital specimen of the peacock and peahen

5140 A very fine specimen of the ash-coloured boat-bill, Carscroma cochlearia, extremely rare 
5141 Crystallized blende, on opake white quartz, crystallized carbonate of barytes, and another

5142 A singular pyrites, from Scarborough ; asphaltum, Trinidad; asbestos, amianthus, and two others

5143 Seven various volcanic specimens, from Vesuvius

5144 Red and yellow clay, asbestos in the matrix; volcanic glass, Teneriffe; and two others

5145 Light brown asbestos, Scotland ; and three others

5146 Hyalite, Franckfort; adularia in basalt, Hesse; and two others

5147 hæmatites in basalt, zeolite in ditto, and four others

5148 Birds nest incrusted by salt, two branches ditto, and a specimen of aluminous wood

5149 Six various large minerals, from Hesse

5150 Nine small ditto, including native gold, red oxyd of lead, solid gray cobalt, porcelain jaspar, \&c.

5151 Crystallized bright gray cobalt, Franckenberg; copper ore, and another, from Hesse

5152 Amianthus, asbestos, mica, and sundry others

5153 Ten various volcanic productions, from Vesuvius

5154 The white beryl of Siberia, finely crystallized

5155 Large and accurately crystallized Brazilian topaz

5156 Very large arrow-headed selenite, from Monte-Martre, near Paris

5157 Three large and various specimens of jaspideous wood, and another

5158 Ten small specimens, including oxyd of chrome, prase, cobalt, cinnabar, \&c. \&c.

5159 Spotted basalt, (basalt maculée of Faujas de St. Fond) zeolite in basalt, and another, Hesse

5160 A large and fine specimen of solid grcy cobalt, Hesse

Find of the Forty-third Day's Sale. 


\section{FORTY-FOURTH DAY.}

\section{Wednesday, the 25th of June, 1806.}

5161 A curious foreign sword

5162 A brass celt, and three large stone ditto

5163 Four curious turkish pipe heads, and a North American ditto

5164. A small bronze and seven various Roman antiquities

5165 A large cup formed of mottled green stone

5166 A Roman fibula, and three others

5167 An elégant circular box made of red hardened steatite, and a curious pipe head

5168 Eight various Turkish and other pipe heads

$5169 \mathrm{~A}$ basket curiously ornamented with white nerite shells, Friendly Islands

5170 A very large ornamented basket, from the Friendly Islands; three smaller, and sundry ornaments

5171 A nephritic stone idol, and six various instruments, from Otaheite

5172 Three shell neckłaces, from Otaheite; and a feather ditto, from the Sandwich Islands

5173 A curious crnamented box made of the hollow trunk of a tree, Friendly Islands

5174 Four various baskets, from the South Sea Islands

5175 Complete dress worn by the King of Otaheite at a human sacrifice

5176 Twenty-one eggs, chiefly of the larger aquatic birds, among which are those of the albatross, penguin, American owl, parrot, and cockatoo, and a singular lusus 
5177 Two of the hanging birds nests, suspended from the leaves of a palm

5178 An extensive collection of the eggs of small British birds, including a number of rare speciniens

5179 A black and yellow, and a white feather cloak, from the Sandwich Islands

5180 Remarkably well-executed dancing mask, from Nootka Sound

5181 Speckled azure snake, large and fine

5182 Twenty-six eggs of large birds, chiefly water fowl, some scarce

5183 Fourteen ditto, including those of the puffin, white pea hen, goose, and a very singularly elongated lusus

5184 Water newt, with the comb-like dorsal crest, a pleuronectes, and another

5185 Large specimen of ycllow gum, from Botany Bay; red ditto, and various others

5186 Silvery pike fish

5187 Five small fishes, \&c. in six bottles

5188 A fine specimen of testudo Midas

5189 A large and a smaller saw of saw fish

5190 Nest of the tree ants, cut open, Africa

5191 Wasp's nest, curiously formed on a small branch of yew

5192 Various specimens of the Tcrmites, or white ants, in different stages, together with specimens of their buildings, bhiefly from Agrica.- They were presented to Sir Ash. ton Lever, by Mr. Henry Smeathman, and are described in vol. LXxi. of the Philosophical Transactions.

5193 Nest of the tree ants, Africa

5194 Part of hornets nest, East Indies

5195 Ditto, Cayenne

5196 Part of a very large nest of the tree ant, Africa

5197 Section of a large hornets nest, East Indies

5198 A complete nest of the same species, ditto

5199 Cylindrical cell ef the tarantula spider, and a hornets nest

5200 Nest of a large hornet, East Indies, and another

5201 Ditto, two specimens, one shewing the internal structure

5262 Cylindrical cell of the tarantula, insect galls, delicate comb of a small bee, nest of a large horhet, East Indies; and ditto of the tree-ant, Cayenne

5203 Cacao nut, branch of legatto tree, with its curious bark, and two curionis nuts

5204 A bird's nest on a branch of the Banksia, a hanging nest, and sundry foreign vegetable substances

5205 A fine specimen of gum senega, and three others

5:06 Cotton made from the flax, cotton in the pod, and sundry curious vegetable substances 
5207 Two fine specimens of camphor wood, rich in camphor, inclosed in a glass

5208 Upwards of one hundred specimens of rare and beautiful foreign woods-an interesting series

5209 Thirty duplicates of ditto

5210 Thirty-three specimens of English woods

5211 Concentric tortoise, testudo concentrica, and a shell of the testudo geometrica

5212 Six small bottles containing larvæ of insects, a tortoise, \&c. and a bottle, with a number of the scarabæus lateralis

5213 A small tortoise, snakes, larvæ of insects, Sc. in eight bottles

5214 Singularly distorted hoofs of a pig

5215 Shell of the concentric tortoise, testudo concentrica

5216 Testudo Areolata, areolated tortoise, very rare, and the spotted tortoise, two shells

5217 Tricarinated tortoise, and another, the former scarce

5218 A very fine denticulated tortoise

5219 Shell of the serrated tortoise, testudo serrata, extremely scarce, and a small armadillo

5220 Cinereous tortoise of Brou'n, in spirit, and the shell of another

5221 Geometrical tortoise, and two more

5222 Radiated tortoise, testudo radiata, a large sheil

5223 Shell of the painted tortoise, and another

5224 Testudo rugosa, wrinkled tortoise, a fine shell, and very rare

5225 A shell of testudo denticulata, denticulated tortoise, very scarce, and another

5226 Viper-headed snake, and another

5227 Large brown snake, in spirit

5228 Mourning snake, and another ditto

5229 A small crocodile, and an azure snake

5230 Lincated snake, an elegant specimen, and two others, in three bottles

5231 Speckled lizard, and another

5232 A small crocodile, and scolopendra morsitans

5233 Azure snake, America

5234 An elegant banded snake

5235 Skin of the muræna, in spirit

52.36 A fine shell of testudo radiata

5237 Testudo concentrica, the concentric tortoise, an extremely beautiful and well preserved specimen

5238 A curious lizard

5239 Singular Gecko lizard, and another

5240 Dusky snake, spotted suake and a marbled lizard.

524l Tise galliwasp scink, Lacerta occidua, var. 
5242 A large brown linęated snake

5243 Speckled tortoise, Testudo Meleagris, and another

5244 Small blind worm, fishes, larvæ of insects, \&c. in nine small bottles

5245 Small painted tortoise, snakes, \&c. various, in eight small bottles

5246 Two beautiful and curious fishes

5247 An iridescent snake, speckled snake, and another

5248 Dusky wrasse

5249 A small wrasse, and two other fishes

5250 Grey-shot snake, and a cinereous ciitto

525 I Seven small botiles, containing several curious fishes

4252 Small double-headed snake found in Surry

4253 Crocodile, and a singular embryo

1254 Upper shell of testudo imbricata, and two lower shells of a land tortoise

1255 Muræna punctata, chætodon, small mullet,' and three other extremely rare fishes, collected by Captain Cook in the $S$. Seas

5256 Curious acanthurus, and two other fishes ditto

5254 Exocetus volitans, mullet, chætodon, \&c. six specimens ditto

5258 Balistes fascialus, dusky acanthurus, a curious holocentrus, and another ditto

5259 Greenish gomphosus, long-rayed chatodon, and another, ditto

5260 Rostrated chætodon, holocentrus merrá, and parrot bill fish, rare, ditto

5261 Two species of holocentrus, one allied to H. Sogo, Indian ,perch, and another fish, ditto

5262 Indian coryphæna, rare; clupea encrasicolus, var. parrotbilled fish, or scarus; a balistes, and an holocentrus, ditto

5263 Six curious fishes, South Seas, ditto

5264 A balistes, var. of the anchovy, and a singular holocentrus, ditto

5265 Curious fish, allied to fistularia chinensis, and two other rare fishes, South Seas, ditto

5266 Glazed case, with seven bats

5267 A large bat

5268 Curious bat, of a large size, and several of the long-cared bat, in the same case

5269 Canis Bengalensis, Bengal fox

5270 Bull fiog, America

5271 Spotted petrel, (one without case)

5272 Green tody, Todus viridis

5273 Ampelis Cayana, very fine (without case) 
5274 Capuchin pigeon, and common pigeon, two cases 5275 Rice bird, $\mathrm{m}$. and fem.

5276 Grey godwit 5277 Pelecanus punctatus, S. Seas

5278 Squacco heron, Ardea comata, very rare

5279 Austrian pratincole, Glareola Austriaca, (one specimen without case)

$\$ 280$ Ardea pavonina, in very fine preservation

End of the Forty-fourth Day's Sale 


\section{FORTY-FIFTH DAY.}

Thursday, the 26th of June, 1806.

5281 A Large basket, and a petticoat, New Amsterdam, S. Seas

5282 Four small baskets, from the Friendly Isles

5283 A curious and handsome Brasilian feather cap

5284 Fly-flap, with ornamented handle, a feather necklace, and sundry others, from the S. Sea Islands

5285 Green nephritic stone adze, a fish skin file, and sundry others, from New Zealand, \&c.

5286 Dancing girl's apron, Otaheite; petticoat fringe, a feather ornament, for the head, and three others

-5287 Large flaxen mantle, an ornament made of the leg bones of small birds, and another

5288 A Chinese ornamental figure, formed of beautiful pink. steatite

5289 Nests of the esculent Indian swallow, a hang nest, and three other curious nests

5290 Two singular shells of rare tortoises

5291 An extensive assortment of eggs of the smaller, British; birds, including many rare

5292 - A great variety of eggs of British birds, of a larger size than the preceding

5293 Curious sepia, West Indies; and two snakes

5294 Dusky blue snake, a fine specimen

5295 Labrus Tinca

5296 Cærulean snake, several specimens 
5297 Several specimens of the monitory lizard in a large bottle

5298 Small crocodiles, and two snakes

5299 Two curious fishes

5300 Mandarine's fan, Chinese scales, a ditto back-scratcher, and another

5301 White-headed snake, a large and fine specimen

5302 Bengal slippers, aud straw ditto

5303 A handsome pair of ornamented Canadian shoes

5304 Persian slippers, ornamented with the brilliant wing-sheath of the buprestis

5305 Ancient English gloves, and a curious pair of slippers

5306 A pair of shoes made of Indian rubber

5307 Ornamented wooden shoes, ancient English gloves, two pair of curious shoes, and a pair of Persian slippers

5308 Gilt wooden shoes, Hudson's Bay shoes, Canadian ditto, and two pair of Persian slippers

5309 Small spotted tortoise, snakes, fishes, \&c. in nine bottles

5310 Eight bottles, larvæ of insects, fishes, a small bat, lizard, \&c.

5311 Syngnathus hippocampus, pipe fish, spotterl snake, \&c. in eight bottles

5312 Small trunk fish, striped lizard, speckled snake, \&c.-six bottles

5313 A fine specimen of the radiated tortoise, Testudo radiata

5314 The striped, and other lizards, broad banded snake, and blue snake, in 3 bottles

5315 An elegant specimen of the azure lizard, Lacerta azura, and other lizards, a snake fish, \&zc. in seven bottles

5316 Variegated lizard, aud a curious snake

5317 Blue and spotted snakes, singular larva of a lepidopterous insect, a small bat, \&c. seven bottles

5318 Four bottles of snakes, fishes, \&c.

5319 Lacerta occidua, the galliwasp, a fine specimen

5320 Muricated lizard, banded lizard, atherine, hermit crab, and two more

5321 Small banded snake, spotted ditto, \&c. various - six bottles

5322 Seven small bottles, including the spotted lizard, banded newt, \&c.

5323 Small flying oposum, snakes, fishes, \&c.-six bottles

5324 A beautiful tortoiseshell

5325 Small weever fish, silver dory, striped snake, and another-in four bottles

5326 Two small quadrupeds, snake, \&c. in five bottles

5327 Scolopendra morsitans, silvery labrus, \&c. in seven bottles

5328 A fine shell of the rugose shell tortoise, rare

5329 Curious variegated snake, brown snake, and a. blenny, in three bottles

5330 Six bottles, containing small snakes, \&c. 
5331 Cancer mantis of a large size

5332 Three curious fishes, in two bottles

5333 A bottle of large lizards

5334 Two foreign fruits, curious

5335 Shell of the geometrical tortoise, and another

5336 Two snakes, in two bottles

5337 Variegated snake, and another ditto

5338 Gadus tricirratus, a gurnard, singular larva, \&c. in six bottles

5339 Silvery dory, and five other curious articles

5340 Spotted eel, and banded blind worm

5341 Speckled lizard, and three singular snakes

5342 Pipe fish, and two snakes

5343 A large shell of Testudo radiata

5344 Squalus acanthias, picked shark, and clupea pilcardus

5345 A variety of small snakes, in a bottle

5346 Geometrical tortoise

5347 Small crocodiles, three specimens

5348 Small dragonet, and two sepia

5349 The burbot, and another fish -in two bottles

5350 Snakes, fishes, \&c.-in four bottles

$535 \mathrm{l}$ Bull-frog, America

5352 The large variegated Guana, a fine specimen, in a glazed mahogany' case

5353 Ray-fish, and remarkably long tail of a ray, piece of fishskin, and a dried fish

5354 Six various skins of large snakes

5355 Boa constrictor, a fine specimen, being upwards of sixteen feet in length

5356 A small crocodile, from the Nile

5357 The shear-water petrel, Procellaria puffinus

5358 Common bee-eater, Merops apiaster

5359 Common kingfisher, m. and fem. Alcedo ispida

5360 Black guillemot, Colymbus grylle, scarce

5361 Grey gull

5362 Red spotted creeper, certhia cruentata

5363 Common curlew

5364 Fulmar, Procellaria glacialis

5365 Spotted water hen, N. America

5366 Marbled guillemot, Uria marmorata, one specimen

5367 Cinnamon-crowúed finch

5368 Cayenne shrike, Lanius Cayanus

5369 Red-legged partridge

5370 Great brown kingfisher, Alcedo fusca

5371 Crested grebs, Colymbus cristatus, (without case)

5372 Pine grosbeak, m. and fem. Loxia erucleator

5373 Lapwing plover, $\mathrm{m}$, and fem. young and egg 
5374 Two specimens of Alcedo rudis, executed in the birds feathers, in Edwards's manner

$5375^{\text {L Loxia cærulia }}$

5376 Grous, $\mathrm{m}$. and fem.

5377 Psittacus porphyrurus

5378 Nun titmouse, m. and fem. and snipe-two cases

5379 Pin-tailed duck, male

5380 Cinnamon dove, Jamaica

5381 Powter pigeon, cock

5382 Young barn owls, three finely preserved specimens

5383 Hæmatopus ostralegus

5384 Philipine rail, New Zealand, $m$. and fem.

5385 Woodcock variety, and raven, young

5386 Gambo goose, Cape of Good Hope

5387 Red throated loon, one specimen, without case (colymbus septentriolis,) rare

5388 Corvorant, fem.

5389 Song thrush, $m$. and fem.

5390 Black guillemot, Colymbus grylloe, rare

5391 White rurnp'd thrush, Gibraltar

5392 Solitary thrush, Gibraltar

5393 Ouzel, $\mathrm{m}$, and the throstle- two cases

5394 Stock dove, and woodcock-two cases

5395 Yellow eared toucan, S. America

5396 Whinchatter variety

5397 Gambo duck, Surinam

5398 Pompadour chatterer, Ampelis pompadora, $m$. and fem.

5399 Northern diver, Colymbus glacialis, a very fine specimen

5400 A most beautiful specimen of the Nicobar pigeon, Colum. ba Nicalarica, very rare

End of the Forty-fifth Day's Sale. 


\section{FORTY-SIXTH DAY.}

\section{Friday, the 27th of June, 1806.}

5401 ARGE sleeping stool, and a meat dish, Otaheite

5402 Two large and handsome baskets, from the South Sea Islands, and a small ditto

5403 A small beautifully oruamented case, from ditto, and a flute

5404 Palm-tree cap, and a curious scull cap

540.5 Curious pouch of the North-American Indians, formed of the skin of a large rattle snake, ornamented with the feet and talons of an eagle

5406 Large bag of ditto, a head dress, and another

5407 Pouch of ditto, made of the skin, (with the horns) of a roebuck, and a bead pouch

5108 A singular head dress, from the Marquesas,' and a handsome feather head ornament

5409 An elegant shell necklace, a feather ditto, and two others

5410 Green nephritic stone chissel, and sundry utensils, from the South Sea Islands

5411 A handsome green nephritic stone needle, and sundry others, from ditto

$5412 \mathrm{An}$ idol carved in fine green nephritic stone, and a shell breast plate, New Zealand; a syrinx, and another

5413 Ornamental parts of dress of the North American Indians, and a bracelet, Sandwich Islands

5414 Friar's knife, inclosing a dagger

5415 Two curious tobacco stoppers, mounted with silver 
5416 A feather and two other necklaces, a fish hook, from Otaheite, \&c.

5417 An ivory walking stick head, beautifully inlaid with silver; and a curious double tobacco stopper, mounted with silver

5418 A tea equipage, \&c. \&c. of extreme minuteness, beautifully turned in ivory

5419 A most superb feather hat, the performance of Nuns at St. Salvador in the Brasils. The ground work is white decorated with imitations of flowers executed in feather of the most splendid and rare birds

5420 Black spotted snake

5421 Spotted muræna, warted frogs, spotted labrus, and two others

5422 Singular carinated tortoise, and another

5423 Tichiurus lepturios, Linn. a fine specimen, America; and two snakes

5424 Thorny diodon, small, gadus tricirratus, newt, scolopendra morsitans, and the sprat-in five small bottles

5425 Curious double egg, one shell being formed within the other

5426 An interesting collection of eggs of the smaller British birds, many of which are rare

5427 An ostrich egg, a curious double egg, and another

5428 A hang nest, two esculent nests of the Chinese swallow, and two more

5429 Nest of the water hen, with the eggs, and egg of an ostrich laid in the Tower, May 15, 1747

5430 Singular double egg, and another

$5431 \mathrm{Egg}$ of an ostrich, hang nest of the oriole, and three more

$5432 \mathrm{~A}$ very complete esculent nest of the Chinese swallow, timber perforated by the carpenter bee, and egg of an ostrich

5433 Crotalus horridus, and another snake, in two bottles

5434 A large bottle containing a great variety of snakes, lizards, and other amphibious animals

5435 Curious fish of the clupea genus

5436 ' Singular black wrasse

5437 Broad banded snake, frogs, and the River bullhead

5438 Silver dory, spotted snake, fish, and a singular sponge-in four bottles

5439 A small salamander, Lacerta salamandra, and six other , curious reptiles, fishes, \&c.

5440 The black fish, in a large bottles

5441 Weever fish, and five others, in six small bottles

5442 A variety of snakes, in three bottles

5443 Whelk with its animal, several fishes, \&c. three bottles

5444 Shell of small geometrical tortoise, and two more

5445 Four elegant species of tortoise, one very rare 
5446 Epinephelus merra, (of Block) Japan; and two snakes

5447 Curious marine worm of singular beauty

5448 A large bottle, containing a small crocodile, and several other lacertæ, blind worms, \&c.

5449 Esox stomias, viper-headed pike, and another singular fish

5450 Dusky wrasse, and a snake

5451 Two singular vermes

5452 Speckled snake, a beautiful specimen

5453 Elegant granulated lizard

5454 Grey-banded snake, \&c. in two large bottles.

5455 Dusky wrasse, and another

5456 A very large stuffed specimen of the shark

5457 A ditto of the monk fish

5458 Rough Seal

5459 Lunated seal

5460 Great seal

5461 Round-tailed seal

5462 Antilope cervina

5463 Fawn of fallow deer

5464 Two specimens of the white var. of the mole

5465 White var. of the rat, and a squirrel

5466 A very fine specimen of viverra ichneumon

5467 Lemur catta

5468 White mole, and two rats

5469 White beaver

5470 Fulimart

5471 German hamster, m. and fem.

5472 .Dasypus novem-cinctus -

5473 A beautiful specimen of Moschus Grimmia, very rare

5474 White variety of the wren, and a common wren-two cases

5475 White and brown variety of the wren, and a goldfinchtwo cases

5476 Dun diver

5477 Falco Domingius

5478 Ring-tail eagle, Falco fulvus

5479 Trumpeter pigeon, and common crow-two cases

5480 Tarrock gull (one specimen, without case) Larus tridacty. lus

5481 Ruby-throated warbler, Siberia

5482 Curasso bird, young

5483 Ptarmigan, Scolland

5484 Bantam cock, and common pigeon-two cases

5485 Cat fly-catcher, Kamstchatka

5486 Cross bill ouzle

5487 Young sparrow hawk, and fieldfare, two cases

5488 Loxia psittacea, m. and fem. Sandwich Island-rare: 
5489 Scarlet-headed parrot, Brazils

5490 Little bustard, $m$. and fem. Otis tetrax-rare

5491 Cayenne jay, Corvus Cayanus

5492 Waxen chatterer, Ampelis garulus, m. and fem.

5493 Partridge variety

5494 Blue grosbeak, $m$. and fem. Loxia carulea

5495 Fork-tailed shrike, Lanius forficatus

5496 Ardea minuta, the little bittern, a very fine specimen, shot in Dorsetshire

5497 Pinguinaria parva, rare

5498 An extremely fine specimen of Paradisea apoda

5499 Two of the yreen knobbed sun, W. Indies; a beauty limpet, three cassidæ, the cock's-wing clam, and eight other shells

5500 The cancellated trochlea, Sicily; the purple-rayed, the abreviated, and slender solens, the painted lunatus, the partridge cockle, and nine other shells

5501. The grey rosarium, a vice-admiral, and three other cones, the painted and bleeding teeth neritæ, the red clam, the grey chersin, and eleven other shells

5502 The semi-violet oceanic snail, (Helix janthina, Linn.) the tiger cat cone, the sanguineous tellen, the banded frog, the strawberry rosarium, the white rose, (Tellina divaricata, Linn ) and thirteen more

5503 Nerita versicolor, $W$. Indies; the variegated French horn land snail, the freckled porcelain, the green var. of the parroquet-margaritifera, Friendly Islands; the long netted porcelain, and nine more

5504 Two orange lunati, tellina festiva; trapezium oblonga, two lapwing's-egg porcellanæ, another in a young stage of growth; the pale satchel clam, Guinea; a grey chersin, with a pagurus lodged in it, W. Indies; pectunculus nodulosus, and six others

5505 A variety of shells of different genera

5506. The map porcelain, from Amboyna; the bellied variety of the occidental argus porcelain, from Providence; 'and a furbelowed clamp, Moluccas-all fine

5507 Head of a fish, apparently of the salmon tribe, in pyrites, Sheppy Islands

5508 An ammonite in a mass of stone, with its counterpart, shewing the pearly inner coating of the shell

5509 Scction of a large ammonite

5510 Large head of a fish in indurated marl, Sheppy

5511 Brown nuable, having belemnitæ and other extraneous fossils imbedded in it, from Germany

5512 Fossil madrepora, a large specimen; and two smaller

$5513 \mathrm{~A}$ mass of tish scales in blue marl

5514 A chrysolite, cut and polished 


\section{[46th day.]}

LEVERIAN MUSEUM.

5515 A hyacinth, ditto; an amethyst, ditto; and an amethyst, India cut

5516 A handsome brown cat's-eye, cut and polished

5517 A sapphire, and an emerald, ditto

5518 A Brasilian ruby, ditto

5519. A fine-coloured oriental ruby, and a ditto crystallised

$5520 \Lambda$ crystallized diamond

End of the Forty-sixth Day's Sale. 


\title{
FORTY-SEVENTH DAY.
}

\author{
Saturday, the 28th of June, 1806.
}

$\prod$ small basket, and two salt dishes, Sandwich Islands

5522 Four various baskets, from the South Sea Islands

5523 Ornamental parts of dress of the North American Indians, and a bracelet, Sandwich Islands

5524 A dog's tooth ancle ornament, from ditto, and specimens of New South Wales flax

5525 Ancle ornament, made of shells ; cocoa-nut sandals, a playing bowl, and a salt dish, from Sandwich Islands

5526 A small idol, from Otaheite; and another, from Sandwich Islands

5527 A curious cap, Nootka Sound; a cloth beater, and two others, from Otaheite

5528 Sundry harpooning instruments, \&c.

552.9 A small Roman altar, having the patella

5530 Ancient monumental stone of a Roman soldier

5531 A string of the oily nut kernels, with which the natives of the Friendly Islands make their flambeauxs

5532 A stone pestle for pounding bread fruit, à specimen of bread fruit, and a cloth beater

5533 Artificial hair, ancle ornament, and four playing bowls, from the Sandwich Islands

5534 A long bone dagger, and a basaltic adze, Sandwich Islands

5535 An extremely curious basket, made of fine grass, from Onalaski, and another made of a skin

5536 Curious bracelet, a gorget, and two adze heads, Sandwich Islands 
5537 Four various fish-hooks, a bracelet, a shark's tooth instrument, and two others

5538 Large roll of cordage, four mirors, and sundry fish hooks, Sandwich Islands

5539 A wolf's head mask, and another, Nootka Sound

5540 A most superb green scarlet and yellow feather cloak, particularly described in former catalogue

5541 Curious and rare star-stone, with gorgonia flabellum

5542 Muricated madrepore, a fine group

5543 Large piece of timber, perforated by the teredo navalis

5544 Pipe wire sponge, a fine specimen, West Indies

5545 Small star madrepora, a fine specimen

5546 Black antipathes, and a fine branch of the red kind of gorgonia setosa

5547 A singular flat variety of madrepora muricata, West Indies, rare

5548 Madrepora labyrinthica (brainstone) West Indies

5549 Ditto

5550 Antipathes spiralis, East Indies; and a large specimen of the red variety of gorgonia setosa, Linn. or sea-feather

5551 Seven fragments of stones and wood, pierced with pholades, \&c.

5552 May-blossom coral, Madrepora ramea, an extremely fine specimen $4-5+5$

5553 A curious variety of millepora muricata $>0$

$5554 \mathrm{Crab}$, with a number of oyster shells adhering $2-6$

5555 Millepora alcicornis, a large and fine specimen $1-7-6$

5556 Group of the muricated madrepore, West Indies

5557 A noble group of millepora alcicornis, Linn, ditro $2-12-$

5558 Gorgonia setosa, a very large specimen

5559 Muricated millepore, fine, and a large branch of the red forgonia setosa

5560 White variety of gorgonia setosa, Linn.

5561 Muricated white coral, Barbadoes; madrepora murioata $0+19^{-0}$

5562 A fine specimen of ditto $0,-16-0$

5563 Cinereous snake, and two others $0-5-0$

5564 Coryphena hippurus $0-4-0$.

5.565 Mole, var. and a squirrel $4-0$

5566 Flying squirrel 8

5567 Sea otter, young 19

5568 Grey squirrel, N. America

5569 Leopard, young 19

55 70 Mole variety, long-tailed field mouse variety, and a water shrew.

5571 Pig, Surinam

5572 Common hare, having but one ear

5573. White squirrel, N. America $D+7-6$

5574 Young fawn-coloured rabbit 3.6 .6 
5575 A fine specimen of the Indian ichneumon 6 ?

5576 Mole variety, and a young hare 3

5577 Fulimart $\theta-\infty$

5578 Arctomys empetra Canadian marmot o 5579 Brant fox 6

5580 Cuvia aperia, rock cavy $5-6$

5581 Largest weasel, and rat variety-two cases 5 -

5582 Pekan weasel, N. America

5583 Head and beautiful horns of antelope $/ 8$

5584 Woodcock variety $10-6$

5585 Linnet variety thife $\frac{1-5}{4}$

5586 Jackdaw variety a 80

5587 Long-tailed butcher-bird, Lanius niger, rare 48 -

5588 Feruginous rook, S. Ameriva

5589 Young barn owls', and woodcock-two cases

559 (r Young coots, (four specimens) and young red legged partridge-two cases

5591 Purple winged duck, an undescrilied species 2

5592 Nightingale, $m$. and fem.

5593 Ampelis cayana, a beautiful specimen

5594 Black breasted plover, Hudson's Bay

5595 Lanus ridibundus, m. and fem. $-14=0-0$

5596 Speckled sandpiper -13

5597 Guinea pintado, $m$. and fem.

5598 Pintailed grous, N. America

5599 Charadrius himantopus, rure $\&$

5600 Loxia leucoma hay

5601 Red headed nun pigeon

5602 Godwit, N. America

5603 Psittacus Alexandri -10.6

5604 Spotted petrel

5605 Snow bunting Emleriza nizalis 14

5606 Columba uncirostra, m. and fem. very rare

5607 Otis tetrax /

5608 Dusky headed parrot

5609 Rook, hen; and tumbler pigeon

5610 Black headed linnets, E. Indies

5611 Starling, ox-eye titmouse, m. and fem. and yellow wag, tail-three cases 18

5612 Alcedo sacra, $m$. and fem. $i=0^{-}-5$

5613 Cuckow, young; and red grosbeak-two cases $10-6$

5614 Black grous, $m$. and fem. tetrao tetrix $3-1 / 3-6$

5615 Corvus calvus 7

5616 Psittacus fuscatus, South Seas

5617 Sparrow hawk, hen

5618 Pied pheasant, $\mathrm{m}$. and fem. $\|=1 /+6$

5619 The Leverian shrike, Lanius Leverianus, extremely scarce

5620 Corvus cristatus 
5621 A most beautiful and matchless specimen of the Impeyan pheasant, Phasianus curvirostris, exceedingly fire and rare

5622 Antipathes meriophylla, and a gorgoma

5623 Beautiful purple gorgonia, whence unknown -

5624 Knotted gorgonia, sponge, and two more

5625 Two varieties of gorgoniæ, purple and yellow

$5626 \Lambda$ very fine specimen of madrepora verucosa, East Indies

5627 A very fine and large specimen of the common tortoise

-5628 Madrepora damicornis, East Indies

5629 Antipathes myriophylla, from the Molucca Islands

5630 Madrepora rosea (hirtella Pallas) Providence Island, a beautiful specimen

5631 Two gorgoniæ, and two corals

5632 Madrepora verucosa, warted coral, East.Indies, a fine specimen $1+5-8$

5633 Corallina tribulus, Caltrop coralline, West Indies; and two others 0 .

5634 Miliepora truncata, and an elegant arborescent coral

5635 Madrepora fungites, a scarce variety, naturally affixed/to a shell of the spondylus Martinique

5636 Millepora truncata

5637 Tubipora musica, and the warted gorgonia

5638 Millepora cærulea, a large and fine specimen

5639 A fine muricated madrepora, East Indies, rare

5640 Madrepora phrygia, or lace-work brainstone, East Indies, a specimen of uncommon elegance and perfection

End of the Forty-seventh Day's Sale. 


\section{FORTY-EIGHTH DAY:}

Monday, the 30th of June, 1806.

5641 WO feather fly-flaps, \&c. Sandwich Islands

5642 A small variegated feather cloak, and sundry feather ornaments, from ditto

5643 A small idol, Sandwich Islands; and a ditto, from Otaheite

5644 Fur girdle, and a pair of fur boots, Cook's River

5645 A singular shark's tooth instrument, and a large Basaltic adze

5646 An ornamented comb, a whistle, and sundry small carved figures, King George's Sound

5647 Beautifully carved spontoon of a New Zealand Chief

5648 A curious bow, from Tshukutski; and another

5649 A beautiful green nephritic stone idol, New Zealand

5650 A dark-coloured feather cloak, and feather ornament of a curious pattern

5651 Necklace made of shark's teeth and feathers, model of a canoe, feather necklace, leg ornament, from Newfound. land; and another.

5652 Two carved bowls, an elegant small basket, a war weapon, and a fan S. Sea Islands

5653 A curiously formed box, a war weapon, and a basaltic adze, King George's Sound

5654 Beef, which formed part of the ship's stores of the ressel in which Lord Anson circumnavigated the globe

5655 Rice skreen, China 
5656 Curious female figure in bronze, China

5657 Two grotesque figures in wood, and two fly-flaps, China

5658 Two models of Chinese lanthorns, and a Chinese padlock

5659 The Lord's prayer finely written in the compass of a silver penny, and a bundle of pens made of very minute quills

$5660 \mathrm{~A}$ dish and ladle curiously ornamented and carved in pink steatite, from China; and an extremely thin specimen of fine mother of pearl

5661 A feather helmet, and a piece of matting, Sandwich Islands

5662 A remarkably large feather idol, from ditto

5663 A feather fly-flap, a dagger, a bowl and platter, from ditto; and a head ornament, from ditto

5664 A feather ornament of singularly beautiful pattern, another feather ornament, and two specimens of matting, from ditto

5665 A pair of large egg-shaped fluor ornaments

5666 A light-coloured fluor vase, and three ornamental pieces of fluor

5667 Nine various ornamental pieces of fluor

5668 A pair of salts in fluor, and three others

5669 A cup and saucer formed of beautiful purple fluor.

5670 A very fine pair of variegated brown and purple fluor vases

5671 Bull frog, America

5672 Short-tailed pangolin or manis, an undescribed species, Africa

5673 Small spiny scaled pangolin, a nondescript speices

5674 Three small chameleons

5675 A fine impression of Sherwin's engraving of Capt. Cook

5676 A very large mortar made of red marble

5677 Common snake

5678 Variegated lizard, East Indies-rare

5679 The guana lizard, a fine specimen

5680 Bull frog, America

5681 A case of small frogs

5682 Long-tailed lizard, East Indies, very scarce; and a small variegated long-tailed lizard

5683 Three curious land tortoises, two of them very rare

5684 Crotalus horridus - in spirits

5685 A young crocodile

5686 Lacerta levériana, very curious and rare

5687 Common toad

5688 Larger bull frog

5689 Spotted lizard, East Indies

5690 Java lizard, rare

5691 Lemur lori, (one specimen without case)

5692 Lesser weesel, and a bat 
5693 Bradypus tridactylus, young, (without case)

5694 Variety of the beaver

5695 Arctic fox

5696 Didelphis dorsigera, m. fem. and young:

5697 Legs and horns of the small African deer, and a common weesel

5698 A curious water rat

5699 Fisher sable, N. America

5700 A very fine specimen of the Bengal hunting leopard

5701 Bonnetted monkey of Pennant, very rare, Simia pileata

5702 Viverra jcnetta

5703 Capra Angorensis, very fine

5704 Musk hog, Mexico

5705 White var. of the rat

5706 The wolf in fine preservation

5707 Remarkably large rabbit

5708 Chinese dog

5709 Marten

5710 Musk cat

5711 Leverian fossane, a very fine and rare specimen

5712 A beautiful specimen of the white Canadian porcupine

5713 White var. of the mole, and mole, N.America-two cases

5714 Puffin auk, Alca arctica

5715 Alca alle, m. and fem. Greenland

5716 Black-toed gull, rare

5717 Turn stone, America, m. and fem.

5718 Spotted petrel

5719 Lesser tern, m. and fem. Sterna minuta

5720 Sterna hirundo, m. and fem.

5721 Black-throated linnet, America

5722 Chaffinch, male and female

$5723 \mathrm{Knot}$ bird, and young of the great crested grebe

5724 Short-eared owl, Strix brachiotus

5725 Green plover, var.

5726 Pheasant of Hudson's Bay.

5727 Common pigeon

5728 Trumpeter pigeon

5729 Tufted duck, male

5730 Dusky parrot, Psittacus obscurus, rare

5731 Sea swallow, Sterna hirundo

5732 Corn crake

5733 Little egret, Ardea gurzetta, fine and rare

5734 Sterna stolida, m. and fem.

5735 Sterna alba

5736 Small black petrel, N. W. America

5737 Long-eared owl

5738 Scaup duck, male

5739 Water rail, Surinam 
5740 Brown duck

5741 Large green parrot, Brasil

5712 Guillemot

5743 White fronted dove

5744 Drumming partridge

5745 Large fly-catcher, $m$. and fem. South Seas

5746 Tarrock gull, Larus tridactylus

5747 Orange-throated lark, Cape of Good Hope

5748 Large yellow wagtail, S. America

5749 Hawk-headed parrot, rare

5750 Partridge variety

5751 Common magpie

5752 A fine specimen of the tufted dunghill cock

5753 Ditto of the hen

5754 Loxia dominicana

5755 Water ouzel variety

5756 Orange-faced parroquet

5757 Tantalus falcinellus, shot in Kent

5758 Glareola Austriaca, Austrian pratincole

5759 The female woodchat, Lanius rufus-rare

5760 Ardea minuta, the little bittern, an extremely fine spesimen, shot in Lincolnshire

End of the Forty-eighth Day's Sale. 


\title{
FORTY-NINTH DAY.
}

\author{
Tuesday, the 1st of July, 1806.
}

$5761 \rrbracket$ WO feather fiy-flaps, a pair of idol's eyes, and a fea. ther necklace, Sandwich Islands

5762 Boar's-tusk bracelet, shark's-tooth instrument, basaltic adze, a dagger, \&c. from ditto

5763 Stone hand-weapon, King George's Sound; a hemp beater, a necklace, and two combs

5764 Three various clubs, South Sea Islands; and an adze

5765 Small dark coloured feather cloak, and a feather ornament of a curious pattern

5766 Remarkably large meat dish, and a sleeping stool, Otaheite

5767 A very curious feather idol, Sandwich Islends

5768 Feather fly-flap, a pair of mother of pearl idol's eyes, and a basaltic adze

5769 Shark's tooth instrument, a gorget, a necklace, a bunch of fish-hooks, and a small idol, Sandwich Islands

5770 Necklaces, combs, \&c. Sandwich Islands

577 Sundry parts of dress of the North American Indians

5772 Two pair of North American-leathern stockings, Chinese scull cap, and a pair of wicker Chinese slippers

5773 A most superb Turkish, robe, formerly the property of the Hon. Wortley Montague

5774 A pair of large purple fluor vases, (damaged) and three fluor ornaments.

5775 A pair of salts made of beautiful variegated fluor, a small vase, and two others. 
5776 Simia luteola, yellow monkey

5777 Bradypus tridactylus, young

5778 Red crested monkey

5779 Pig tailed baboon, Simia Nemestrina, Linn.

5780 Lemur lori

5781 Bonnetted monkey, Penant, Sim. pileata, rare

5782 Lion tailed monkey, Simia ferox, without case, very rare

5783 Striated monkey, Sim. Iacchus.

5784 Ditto, differently varied in colour

5785 Royal monkey, Sim, seniculus, Linn.

5786 Small black monkey, Sim. Midas

5787 Chinese bonnet monkey

5788 Monkey from St. Jago

5789 A fine specimen of Simia Maimon

5790 A capital ditto of Simia Mormon

5791 Viverra putorius, N. America

5792 Grey squirrel, N. America

5793 Pig, Surinam

5794 Blue headed finch, Fringilla cyanomelas

5795 Little green parroquet, Botany Bay

5796 Marbled guillemot, Uria mar morata

5797 Turnstone, America

5798 White throat, m. and fem.

5799 Buff-coloured crested fowl, Africa

5800 Red throated loon, Colymbus septentrionalis, rare

5801 Buffalo headed duck

5802 Noddy bird of North America

5803 North American robin

5804 Red legged partridge, Guernsey; and the hen knot bird

5805 Water ouzel, male and female

5806 Red pole, Hudson's Bay; and a variety of the common wheatear

5807 Fly-catcher, male and female

5808 Large blue American kingfisher

5809 Grey godwit, and a young cuckow

5810 Green parrot, South Anierica

5811 Pink breasted grosbeak

5812 Green plover

5813 Russet wheatear, var. Gibraltar, described by Latham as a var. of the common

5814 Greater tinamou, South America

5815 Tufted duck, male

5816 Icteric oriole

5817 Hobby hawk, and stannel hawk

5818 Blackbird, and linnet

5819 Lesser Banana bird, and the house sparrow

5820 Common cross-bill

5821 Spotted cuckow, South Seas 
5822 Bald coot

5823 Woodcock

5824 Blackbird, male and female

5825 Greater brambling

5826 Bantum cock

5827 Carrier pigeon

5828 Parrot, a curious variety, America

5829 Green creeper; South America

5830 parrot, South America

5831 Larger sanderling

5832 Hen of the stannel hawk

5833 Cowry finch, East Indies; and blackcap, Gibraltar

5834 Brambling and another

5835 Missel thrush and green finch

5836 Grey wagtail, and lark variety

5837 Hoopoe male

5838 Ruff, male, and the common bullfinch

5839 Blackbirds, male and female

5840 Woodlark, and the young razor bill

5841 Fly-catcher, male and female

5842 Woodcocks, North America

5843 Twite, and young redstart

5844 Curious variety of the lark

5845 House sparrow, and young cuckows

5846 Mouse-coloured linnet, North America; red winged thrush and another

5847 Brown American owl

5848 Poker duck

5849 Pied martin, North America

5850 Green wren

5851 Stone chatterer, and white wren

5852 Whin chatterer, and skylark

5853 Tufted starling, young starling, and avadavad

5854 Black-fronted flycatchers, nuthatch, stone chatterer, and another

5855 Coldfinch, woodlarks, and green wren-three cases

5856 Blue timouse, coldfinch, and sparrow

5857 Young sandpipers, wren, and ox eye titmouse-three cases

5858 Grasshopper lark

5859 Yellowfinch, America; and a crossbill

5860 Variety of the robin, and ditto of the chaffinch

5861 Red-legged partridge, Barbary

5862 Nun or black and white smew

5863 Bantum cock

5864 Large swift, Gibraltar; chaffinch and wren

5865 Purre, and titlark

5866 Yellow bellied finch, Africa; young cuckow

5867 Large butcher bird 
5868 Ruff male, and young, of the bastard plovers

5869 Grey parrot

5870 Large wren, of Cayenne; and another

5871 Young starling, and a case with three small birds

.5872 Marsh titmouse, male and female

5873 Variety of the linnet

5874 Waxbill grosbeak, Loxia astrild

5875 Oriolus niger

5876 Green dove, South Seas-rare

5877. Black-capped parroquet, rare-Psittacus melanocephalus

5878 Quail, N. America

5879 Loxia sanguirostris, the taylor bird, three specimens, with one of their curiously formed nests

5880 Tanagra tetao, m. and fem. in fine preservation, Paradise titmouse

End of the Forty-ninth Day's Sale. 


\title{
FIFTIETH DAY.
}

\author{
Wednesday, the 2nd of July, 1806.
}

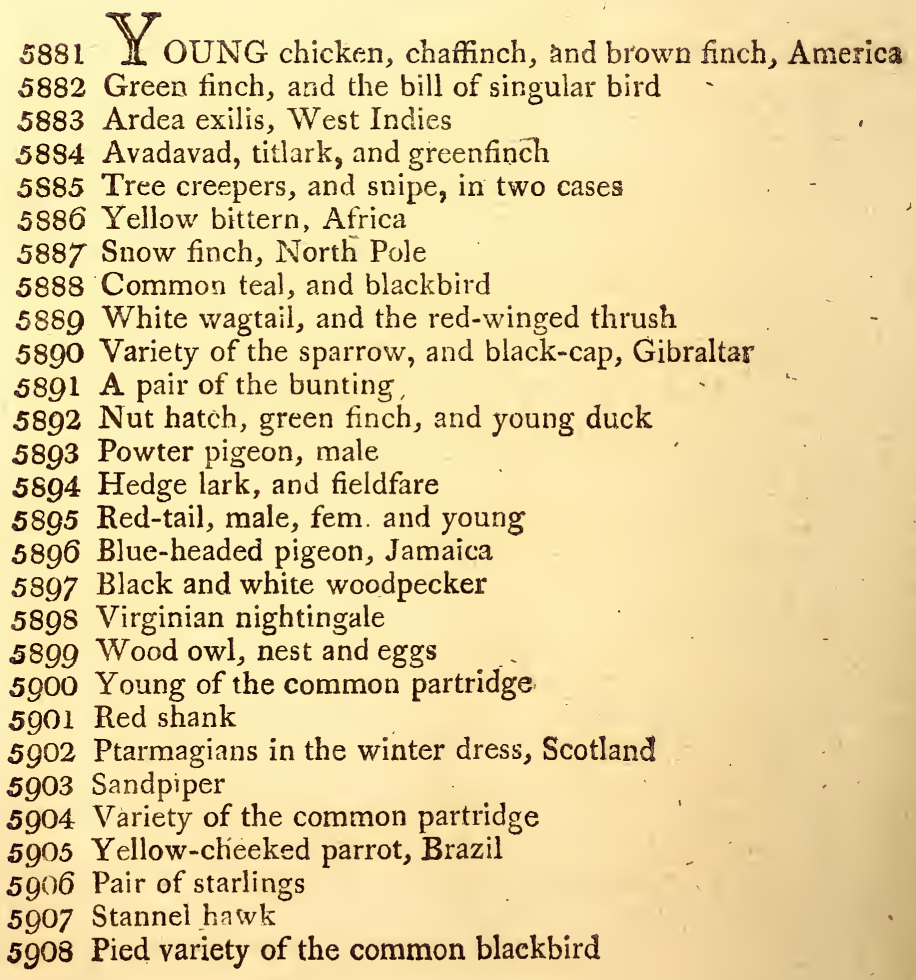


[50th day.] LEVERIAN MUSEUM.

5909 Black grosbeak, S. America, both sexes

5910 Bastard baltimore bird, and the red-tail

5911 Wax-bill, East Indies; marsh titmouse, and young duck

5912 Bald coot

5913 Two varieties of the twite, and the sand martin

5914 Sandpiper, and the knot

5915 Singular variety of lark

5916 Bunting lark, and titlark

5917 Canary bird.

5918 Blue titmouse

5919 Hybrid linnet, and canary

5920 Rallus porzana, small spotted water hen

592 I Cross-billed lark, a curious lusus

5922 Bald coot

5923 Canary bird, and a curious olive-coloured wren

5924 Yellow-shouldered titmouse, Surinam

5925 Sea lark, a pair

5926 Larger spotted woodpecker, and summer titlarks

5927 Green plover

5928 Pied whidah bird, East Indies, rare

5929 Yellow wagtail

5930 Wryneck

5931 Chicken

5932 Wagtails, a pair

5933 Buff-breasted tringa

5934 Young corn crakes

5935 Tobago hawk, Falco Domingus

5936 Bonana bird, yellow hammer, and starling

5937 Canary ditto, with its egg, and a wheat-ear

5938 Guillemót

5939 Spotted-necked turtle dove, Buckinghamshire

5940 Young snipe, and a pied blackbird

5941 Lesser sea swallow

5942 White var. of the common crow

5943 Blue crested American jay, rare

5944 Paradise sparrow, a pair

5945 Common snipe

5946 Green woodpecker

5947 White variety of the thrush

5948 Hawfinch, and a snipe

5949 Bullfinch, and red-tail

5950 Red-crested grosbeak

5951 Snow finch, America

5952 Black-caps, and the reed wren

5953 Nightingale, Gibraltar; and the turtle dove of the West Indies

5954 Carrier pigeon

5955 Sparrow owl, Holland 
5956 Swift, male and female

5957 Sandpiper

5958 Pied variety of the hedge sparrow

- 5959 Black-headed gull, North America

5960 Whin chatterers, male and female

5961 Spotted woodpecker

5962 Chaffinch, and white var. of the swallow

5963 Yellow wagtail, and whin chat

5964 Reed sparrow, America

5965 Sand martins, a pair

5966 Gibraltar nightingale

5967 Goldfinch, cheveril, and red tail

5968 Water rail, a pair

5969 Gold-crested wren

5970 Bunting, and the brown linnet

5971 Light-coloured variety of the robin, and another

5972 Swift, and stormfinch

5973 Snow bunting, and another

5974 Robin, and hybrid canary linnet

5975 Petty-chaps, Gibraltar; waxen-bill, and another

5976 Nut hatch

5977 Var. of the common turtle dove, Buckinghamshire .

5978 Robin, male and female, and ox-eye titmouse

5979 Jamaica fly-catcher, and young snipe

5980 Nightingale, Gibraltar

5981 Scaup duck

5982 Grey scallop-toed tringa

5983 White sparrow

5984 Red shanks

5985 Crotophaga ani

5986 Goat-sucker

5987 Young of the wheat-ear, robin, and another.

5988 Small woodpecker

5989 Hybrid goldfinch, wren, and young rail

5990 White-breasted fly-catcher

$\$ 991$ Canary bird, and bullfinch

$\$ 992$ Greenfinch, and white throat

5993 Teal

5994 Spotted falcon, of Walcot's "British Birds"

5995 Goat-sucker

5996 Shoveler duck

5997 Poker duck

5998 Ardea exilis, minuté bittern, very rare

599.9 North American cuckow

6000 Spotted shouldered fly'catcher, and large American wren

End of the Fiftieth Day's Sale. 


\section{FIFTY-FIRST DAY.}

Thursday, the 3d of July, 1806.

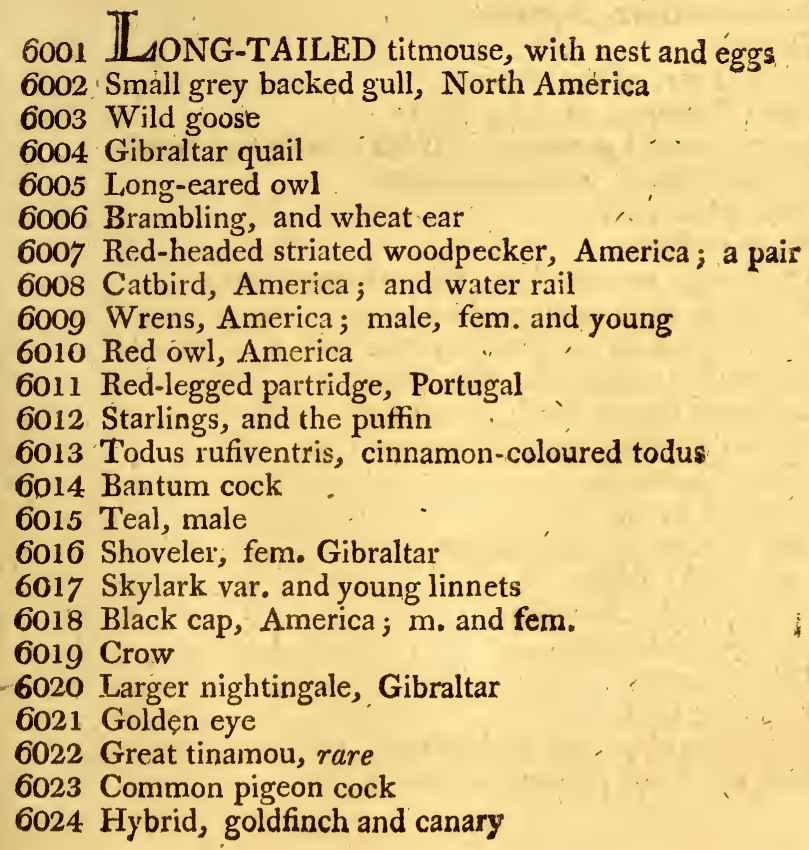


6025 Chaffinch, and sparrow-hawk

6026 Cross-billed crow

6027 Partridge

6028 Cole goose, a pair

6029 Scolopax Cauralia, South America, rare

6030 Red banded humming bird, male

0031 Golden crested wren

6032 Psittacus porphyrocephalus, male and femalé, extremely. fine and rare

6033 Jacamar, male and female, fine

6034 Yellow rumped finches

6035 Stix variegata, little horned owl

6036 Blue grosbeak, America; m. and fem.

6037 Variezated wren, North America-a pair.

6038 Grey wagtail, and common pigeon

6039 Wheat ear, male and femalè

6040 European nuthatch, Sitta Europæea

6041 Psittacus pacificus, South Seas

6042 Grey wagtail

6043 Common creeper, Certhia familiaris

6044 Sea-lark

6045 Strix flammea.

6046 Cinnamon Dove, Jamaica

6047 Widgeon

6048 Crossbill var. of the pigeon

6049 Lanius Barbarus, Barbary shrike

6050 Orange-fronted parroquet, Africa ; male and female

6051 Columba indica, a fine specimen

6052 Large white tern

6053 Young cuckow

6054 Ferruginous woodpecker, Picus cinnamomeus

6055 Humming birds, with nest and eggs

6056 Bucco Cayennensis, black spotied barbet

6057 Turquoisine parroquet, New Holland 18

6058 Variegated brown quail, South Seas /3

6059 Lanius tyrannus, variety, $\mathrm{m}$. and fem.

6060 Yellow headed oriole

6061 Pin-tailed whidah bird $1-1 / 6-0$

6062 Canary, Cape of Good Hope

6063 Black finch, Africa 6

6064 Painted finch, America

6065 Blue grosbeak, America

6066 Skylark variety

6067 Humming bird 6068 Black-winged parrot, S. America

6069 Orange-winged parroquet, Brazils 
6070 Sapphire crowned parroquet, Psittacus galgulus, very fine and rare, $m$. and fem. $3-13-6$

6071 Spirit duck 6, 6

6072 Storm finch 6.6

6073 Lemon-winged parroquet, Brazils

6074 Olive birds, $m$. and fem. S. America $/ \$-6$

6075 Partridge variety $5-6$.

6076. Black gull $7-6$

6077 Large spotted cuckow, Africa 56

- 6378 Columba'Indica 5

6079 Petrel, King George's Sound 5

6080 Wood pigeon, $m$. fem. and young $/ 3$

6081 Black throated crow 4

6082 Crimson throated blackbird, S. America $1-0-0$

6083 A curious quail, from the $\mathrm{E}$. Indies

6054 A ditto kingfisher, S. Seas 4

6085 Long tailed fly-catcher, S. America \&

$6 \oplus 86$ A case containing male, female, and young swallows 7

6087 Large green parrot, Brazils 4

6088 Short eared owl, Strix brachyotos; and a bantam hen-two cases $/=10$ \%

6089 Blue throated redstart, m. and fem. /I

6090. Yellow shouldered thrus $x^{5}-6$

6091 Grasshopper lark 78

6092 Yellow headed parrot, Brazils $/ \sim / \sim 0$

6093 Green linnèt, $\mathrm{m}$. and fem. Surinam -

6094 Beautiful grey and green dove, S.'Seas $1-2=0$

6095 The climbing grakle, Gracula scandens, extremely rare

6097 Scarlet rumped oriole, m. and fem. S. America $y-2$

6098 Three specimens of the yellow finch, Af ica - i

6099 Beautiful specimens of the $\mathrm{m}$. and fem. Surinam chaffinch $/ \cdots$

6100 Lesser crowned pigeon, Columlia cristata, very rare $p \cdot 10$

6 iol Gorgonia flammea, Cape of Good'Hope

6102 Go:gonia, with adhesions, funnel shaped sponge, and another 3

6103 Millepora dama, stag's-horn coral, West Indies

6104 A large madrepore 6

6105 Corallina cylindrica, a curious gorgonia, anci another \&f

6106 Pennatulata phosphorea, an Isis, and another 4

6107 Gorgonia pretiosa, true red coral, a fine branch Groken 1-0-0

6108 A small ramose coral, herring bone coralline, and another $a-10+6$

6109 Madrepora crater, cup madrepore, East Indies 10

6110 Curious yellow gorgonia, and two more $2-6$

6111 Cinnamon madrepore, gorgonia, sponges, \&c. 3

6112 Elegant pink gorgonia, and another $l-6$

6113 Antipathes spiralis, a large branch 
6114 Warted gorgonia, and another $3-6$

6115 Tubipora musica, organ pipe coral, a large specimen $1-10-0$ 6116 Madrepora limax, slug like madrepora, New South Wales, very fine and large

6117 Singular millepore, warted gorgonia, and two more $/$

6118 Curious gorgonia, and two more 4

6119 Screen-like gorgonia, var. of G. Umbraculum, East Indies

6120 Dwarf stellated branched coral, formed on a large piece of black granite, Coast of Guinea

End of the Fifty-first Day's Sale. 


\section{FIFTY-SECOND DAY.}

\section{Friday, the Ath of July, 1806.}

6121 A shark's tooth instrument, a pair of idol's eyes, and two tattooing instruments

6122 A light and a dark coloured adze, and a necklace, S. Sea Island

6123 Parts of foreign dresses, of curious fabric, an ancient purse, and a feather fly-flap

6124 Cap, worked by a negress, and an American straw cap

6125 Napkin made of fine grass (found in Lillyshall Abbey, Shropshire), and pair of old English shoes, a purse, and two others

6126 Three various baskets, from the South Sea Islands

6127 Ornamental parts of dress, of the North American Indians, and a bracelet, Sandwich Islands

6128 Large and a small comb, King George's Sound; and a feather necklace

6129 A handsome Persian ox-tail fly-flap

6130 A variety of Canadian ornamental parts of dress

6131 A curiously carved tobacco stopper, mounted in silver

6132 Another ditto, representing a hound and a hare, and a handsomely carved walnut shell

6133 Small model in ivory, of a human cranium, a curious minute pistol, made of gold and coral, and a carving on a shell's operculum'

6134. Specimens of the window glass, vitrified by the great fire at Ratcliffe; and of corn and flour partially consumed by the fire at the Albion Mills; and another 
6135 A handsome set of tesbiks, or Mahometan devotional beads, and two others

6136 Two large quill feathers of the condor, and the great wing bone of ditto

6137 The Lord's Prayer, written in an extremely small compass, and three specimens of writing, by Sarah Smith, of Kilburn; born without hands or arms.

6138 A case, mounted with silver, containing a rariety of curious cutting in truments

6139 A small Chinese steatite box, with'a carved joss on the lid; and imitation of a snake

6140 Sledge, and dog-harness complete, presented to Sir Ashton Lever, by Captain King, and by him particularly mentioned in Vol. III. p. 202, of Capt. Cook's last voyage

6141 Handsomely carved ivory cane head, bracelet made of red Chinese oil beads, \&c.

6142 Two beautiful feather ornaments, Sandwich Islands

6143 Three various ornamented daggers, from ditto

6144 A beautiful scarlet and yellow feather-helmet, from ditto

6145 A fine academy chalk drawing, handsomely framed and glazed

6146 A large sleeping stool and a meat dish, from Otaheite

6147 An elegant small olive-green feather cloak, and a feather fly-flap, Sandwich lslands

6148 A handsome four-legged sleeping stool, and a basaltic adze, Otaheite

6149 Two curious boxes, a metallic funnel, and ten pieces of Chinese money

6150 Two clubs, and a bone patapatoo, New Zealand

6151 Finely worked spontoon of a New Zealand chief

6152 A beautifully carved club, Friendly Islands

6153 Another very curious ditto, of singular shape, from ditto

6154 War club, made of whale's bone, Nootka Sound; and largée basaltic adze, Otaheite

6155 A bezoar stone, and two porcelain mouth-pieces, for iurkish pipes

6156 Cap, Nootka Sound; a small meat dish, a bowl, a dagger, hemp beater, and shark's tooth instrument, S. Sea Islands

6157 A curious long carved war club, Friendly Isles

6158 An uncommonly large and perfect scarlet and yellow feather idol, witb pearly eyes, Sandwich Isles

6159 Malay creese, in a handsome sheath

6160 A Turkish lady's eyebrow pigment case, made of gold and silver

6161 A fine specimen of trcchilus cristatus, or crested humming bird, on the nest

6162 White and grey tody

6163 Whinchatterer, nun titmouse and another

6161 Hazle grous; m. and fem. Tetrao bonasia 


\section{Lesser Ani}

6166 Blue-headed parrot

6167 Scarlet-vented cockatoo

6168 Black and white finch, $m$. and fem. Africa

6169 Land rail, S. America

6170 Pompadour-fronted parroquet, S. Scas

6171 Black-winged linnet, America

6172 Green butcher bird, S. America

6173 White-fronterl parrot

6174 Motacilla provincialis, the Dartford warbler, $\mathrm{m}$, and ferr.

6175 Cinnamon-coloured tody, S. America, Loxia orix

6176 Cuckow, young

6177 Two most beautiful specimens of the Borneo parroquet

6178 Purplish-olive curlew, S. America

6179 Blue and brown headed kingfisher, m. and fem. S. Seas

6180 Bald-headed parrot

6181 Purple-fronted humming bird

6182 Waxbill

6183 Pink-breasted xanthornus, $\mathrm{m}$. and fem.

6184 Quail, and common pigeon, two cases

$6185 \Lambda$ fine specimen of certhia formosa

6186 Large black and white yellowhammer, America

6187 Ultramarine creeper, m. and fem. S. America

6188 Drumming partridge

6189 Small spotted water hen, S. America, $m$. and fem.

6190 Beautiful red and white var. of the goldfinch

6191 Brown-headed tody

6192 Yellow wagtail, m. and fem. and bulfinch

6193 Fo:ar specimens of the West Indian ground dove

6194 Black and white tern, N. America

6195 Small black heron

6196 Green spotted titmouse, S. America

6197 Spur-winged jacana, Parra jacana, fine and rare, S. Aney rica

6198 Small purple-rumped lory, East Indies

6199 Scull of a trunk turtle, which, when living, weighed upwards of sixteen hundred poumes

6200 Two ramose sponges, and another, a madrepore; and sun dry other zoophy tes

6201 Beautiful group of muricated coral

6202 Fasciculated madrepore, and two other fine corals

6203 Branching millepore, an elegant specimen

62:4 Madrepora anthophyllites, sponge, and another

6205 Madrepora fascicularis, and two other corals

6206 Spongia infundibuliformis, large

6207 Branched sponge, Gulph of Florida

6208 Madrepora porites, a fine specinen, West Yndies K. $k$ 
6209 Fine specimen of the yellow var. of the Venus fan gorgonia

6210 Spongia digitata, Florida ; and a gorgonia

6211 Ditto and another

6212 Millepora rubra, madrepora fascicularis Linn. and five other corals

6213 A glazed case, containing a large group of lepas tintinnabulum, affixed to a portion of timber from a ship's bottom

6214 A large muricated coral, West Indies

6215 Warted gorgonia, a fine specimen, naturally affixed to an arca

6216 Cat's tail sponge, and another singular zoophyte

6217 Millepora alcicornis, a large specimen

6218 Tubipora musica, singular sponge, prickly coral, and another

6219 A group of lepas tintinnabulum, singularly affixed to the summit of a zoophyte

6220 Blue coral, tubular sponge, \&c. various

6221 A variety of sponges, corals, \&c.

6222 Two specimens of the red coral, curious stellated mille. pore, reticulated sponge, \&c.

6223 An uncommonly fine branch of the Isis hippuris

6224 Muricated coral, an elegant specimen $\ldots$

6225 A variety of zoophytes

6226 Purple Venus fan, a scarce var. and two others

6227 May-blossom coral, Isis hippuris, red coral, \&xc.

6228 Three branches of gorgonia pretiosa, sponges, \&c.

6229 A fine branch of the red coral, singular gorgonia, \&c.

6230 Red coral, a large specimen, Sicily; blue coral, and may: blossom coral

6231 Red and yellow varieties of the Sea fan, and another gorgonia

6232 Madrepora fungites

6233 Section of an astroites, coral, and tubular sponge

6234 Muricated coral, and a tubular sponge.

6235 Stone, perforated by shells of the pholas genus

6236 An elegant specimen of the prickly coral, madrepora muricata, a sponge, and another

6237 Millepora alcicornis, stag’s horn coral, West Indies

6238 Gorgonia, with serpula, and other adhesions

6239 Warted gorgonia

6240 Madrepora limax, New South Wales, remarkably large and fine 


\section{FIFTY-THIRD DAY.}
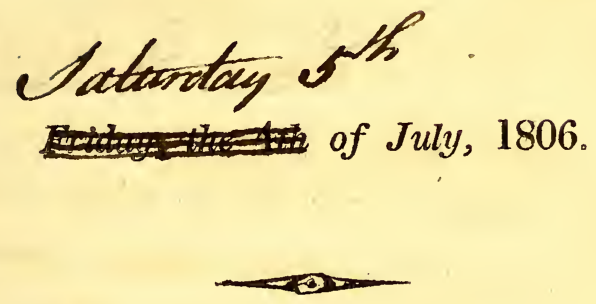

$6241 \mathbb{1}$ EAT äish and sleeping stool, Otaheite

6242 A very perfect basaltic adze, and two sleeping stools

6243 Handsome fly-flap, made of the Persian ox's tail

6244 A curious paddle, South Sea Islands

6245 Two long and one short club, from ditio

6246 A finely carved war club, from ditto

6247 A curious Chinese carving in ivory, and a tobacco stopper made of the timber, of the vessel Centurion, in which Lord Anson sailed round the world

6248 Curiously carved tobacco stopper, mounted with silver; and a Chinese padlock

$6249 \mathrm{Leg}$ and foot of the small African antelope, mounted with gold, as a tobacco stopper, the leg bone of the same animal made into a stopper, and mounted with silver

6250 Large pewter dish, rolled up by Topham, the strong man, and a pewter mug squeezed together by the same

6251 An elegant small dark coloured feather cloak, Sandwich Isles

6252 A scarlet and white feather helmet, and two daggers, Sandwich Isles

6253 An extremely elegant scarlet and yellow ditto

6254 An elegant feather fly-flap, and a small feather cloak, from ditto

$6255 \mathrm{~A}$ bowl, a hemp-beater, a comb, and a singular idol, Nootka Sound 
6256 A hansomely carved dancing rattle, made of bone, model of a canoe, with carved figures, and a small idol, from ditto

6257 An extremely curious war weapon, from ditto

6258 A remarkably curious model of a temple, made of wickerwork, covered with scarlet and yellow feathers, and having a small idol suspended in it-Sandwich Islands

6259 A large bone scoop, Nootka Sound; and two others from T'sukutkski

6260 An uncommonly large and magnificent scarlet and yellow feather cloak and helmet, being the identical articles, with which the celebrated Capt. Cook was decorated by the King of Owyhee

6261 An ancle ornament made of dog s teeth, Sandwich Islands

6262 A curious harpooning instrument, particularly described in former catalogue

6263 A knife case of singularly elegant pattern, Onalaska

6264 Cap, and a club, Nootka Sound

6265 A curious smail double idol; and a cocoa-nut cup, Otaheite

6266 Ornamented belt of North American Indians; a tortoiseshell bracelet, Sandwich Isles; and another

6267 A variety of ornaments, \&c. South Sea Islands

6268 Shell and feather necklaces, \&c. from ditto

6269 A syrinx, a fish-skin fite, and another, Otaheite

6270 Large silken hammock

6271 An extremely beautiful small Turkish shawl, interwoven with silver

6272 Shawl of very large size, from Fez, in Africa

6273 A pair of ornamented leathern stockings, Canada

6274 Parts of a 'Turkish lady's dress

6275 Variegated shawl of a ditto

6276 A Turkish lady's long shawl, interwoven with gold-an article of great beauty

6277 Two handsomely ornamented belts of 'North American Indians

6278 Gorget made of a polished shell, a carved cocoa nut cap, a fish-skin file, and a small syrinx

6279 Case to guard the eyes against snow, Hudson's Bay; and Chinese padlock

6280 A variety of vegetable remains, as burnt wheat, \&c.

6281 Various specimens' of 'paper money issued in America, and sundry others

6282 A large shell onyx, handsomely mounted

6283 Specimens of poetry in different languages, by a persorr confined many years in Bethlem Hospital

6284 Fringilla granatina in the highest state of beauty and preservation

6285 Quan, S. America 
6286 An exceedingly fine specimen of trochilus ornatus, very rare

6287 A curious plover executed in the feathers of the bird, according to Edwards's method, elegantly famed and glazed

$6288 \mathrm{~A}$ most capital, and it is presumed unique, specimen of the great ultramine maccaw, Psittacus hyacinthus, in the highest state of preservation

6289 Loxia orix

6290 Spur-winged jacana, Parra-jacana, in very high preserva. tion

6291 Chinese organ

6292 Drum of the Esquimaux Indians

6293 Pouch and two belts of North American Indians

6294 Various ornaments of ditto

6295 Knife, and elegantly ornamented knife case of ditto

6296 Pouch, two belts, and other ornaments of ditto

6297 A curious drum, from Easter Island, S. Sea

6298 An extremely elegant bead pouch made by North American Indians

6299 Pouch of ditto, chiefly formed of minute porcupine quills

63010 A variety of ornaments, \&c. of North American Indians

6301 Ancient English shield

6302 A ditto, handsomely ormamented

6303 A ditto made of iron

6304 A Chinese shield

6305 Ancient English tilting lance

6306 A very handsome and perfect Persian bow

6307 African war instrument, made of antelope's horns united

6308 A large and curious oriental musical instrument

6309 Ten various oriental and other musical instruments

6310 A pair of Chinese fans, and two others

6311 Two curious African musical instruments

6312 Moorish bridle, and sundry others

6313 Powder horn, with curious devices engraved on its surface by the North American Indians

6314 Chinese ivory beater, and another

6315 A curious spear, a runic almanac, and a North American war club

6316 Three various swords .

6317 Two moorish ditto

6318 Two swords

6319 Four curious daggers

6320 An elegant small French sword, and another

6321 Two curiotas hats from the Bahamas Islands

6322 A curious long Chinese gun, richly ornamented with silver

6323 Three curious oriental hats

6324 A Chinese dagger, and sundry others 
$63 \circ 5$ Fine Chinese ink, and sundry others

6326 Chinese gun, beautifully ornamented with silver, \&c.

6327 Pemarkably long spear

6328 Three various spears

6329 Two curious baboons

6330 Orange monkey, Simia sciurea

6331 Chinese bonnet monkey, and one of the orange monkey

6332 The great-toothed monkey of Pennant, very rare

6333 White-throated finch

6334 Large green and purple pigeon, S. Seas

6335 Carrier pigeon

6336 Loxia Ludoviciana, red-breasted grosbeak

6337 Larger black and white woodpecker, fem.

6338 Red-headed woodpecker

6339 Rough-throated manakin, m. and fem.

$63+0$ Black and ferruginons grosbeak, $m$. and fem.

6341 A curious buzzard hawk

$63+2$ Mountain goldfinch, Jamaica, $m$. and fem.

$63+3$ Certhia afra, young

6344 Dobchick

6345 Cinereous tody

6346 Small white-fronted manakin

6347 Red-crested manakin

6348 Perfectly white variety of the sparrow

6349 A curious charadrius

6350 A small green humming bird, on very curious nest

6351 Emerald-breasted humming bird

6352 Humming bird in its nest

6353 Purple-tailed humming bird

6354 Trochilus superciliosus, fem.

6355 Trochilus polytmus

6356 Certhia afra, var.

6357 Three curious humming birds, one on a nest

6358 Brown-tailed humming bird, rare

6359 Garnet-breasted humming bird

6360 Humming bird on its nest, curious

End of the Fifty-third Day's Sale. 


\section{FIFTY-FOURTH DAY.}

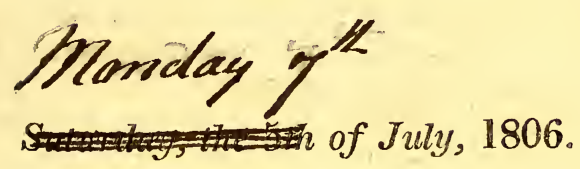

6361 A handsome pouch and ornamented girdle of North America Indians

6362 Ornamented leathern stockings, N. America

6363 Persian slippers

6364 A shark's tooth instrument, and shell necklace, Sandwich Isles; and sundry belts, \&c. of the North American Indians

6365 Bead pouch of North American Indians, the pattern remarkably elegant

6366. Highland purse, with silver mounting, a Chinese purse, and an African cap

6367 Canadian shoes, embossed slippers, and iron instrument for walking on ice

6368 Coat and shue of the Polish dwarf, and shoe of the Corsican fairy

6369 Ladies stilts, used during the century before last-vide Lassel's ar count of Venice

6370 Ladies undress boddice in Charles the Second's time, ancient gluves and hat

6371 Cocoa-nut bowl of a Turkish pipe, richly ornamented with silver

6372 Nootka Snund mantle, ornamented with rows of dried deer's hoofs

6373 Two curious spears, and a handle of ditto

6374 Tro curious daggers, and an ancient English brass-handled pistol 
6375 Orange-coloured silken petticoat and bordering, China

6376 Light blue Chinese robe

6377 Singular Chinese trimming, and a girdle

6378 Jacket, and silk drawers, China ; and a curious ancient flag

6379 A most superb dark purple Chinese robe, with a pair of side ornaments, beautifully worked in threads of gold

6380 Chinese ladies shoes, and North Arnerican shoes

6381 Very handsome Chinese chopstick, with an ornamented case

6382 A pair of bracelets, and curious Chinese boxes, and another

6383 A singular Chinese metallic ornament for the head, with three large pins for the hair

6384 A handsome pair of Turkish slippers, a turban, and tobacco pouch

6385 Bengal slippers, and Canadian shoes

6386 A Spanish rapier and a Persian scimetar

6387 Persian sabre of Damascus steel

6388 Curious long dagger, with a wooden sheath

6389 A handsome Highland sword

6390 A very capital Damascus blade sabre, having the handle inlaid with gold

6391 Long and handsome war club, South Sea Islands

6392 A curious ditto, New Caledonia

6393 Remarkably large adze, Friendly Islands

6394 Beautifully carved short war club, Friendly Islands

6395 Two small sleeping stools, and a small double dish, Otaheite

6896 Beautiful scarlet and yellow feather cloak, Sandwich Isles

6397 A singular war weapon, Friendly Islands; and a club, N. America

6398 Black, scarlet, and yellow feather helmet, a small feather cloak, and a feather ornament

6399 Paddle, New Zealand, and a long spear

6400 Model of a canoe, King George's Sound

6401 Long barbed spear formed of beautiful mahogany-like wood, Sandwich Isles

6402 A long spear of similar wood

6403 A curious fishing instrument, a cocoa nut cup, and another, Sandwich Islands

: 6404 A long instrument used by the natives of the Friendly Jslands in their athletic sports

6405 Large wooden bow! and dish, and a fan, Sandwich Isles

6406 Fish spear, Onuluska

6407 A very curious war instrument; Sandwich Isles

6408 Paddle, S. Sea Islands

6409 Long war club, ditto

6410 Curiously carved heavy war club, Friendly Islands 
6411 Small gourd provision case, a fan, a fish-hook, \&c. S. Sea Isles

6412 An extremely curious and elaborately carved war instrument made of stone, Nootka Sound

6413 Finely carved war club, Friendly Islands

6414 Curious wooden can and sundry others, Nootka Sound

6415 Two shark's teeth instruments, (one very curious) and an adze head

6416 Shell and bead necklace, small idols, worn as ornaments, and sundry others, Sardwich Islands

6417 A very curious war-club, New Caledonia

6418 Pouch very ingeniously made of fine grass, and sundry others, Prince William's Sound

6419 Gorget, bracelet, shark's tooth instrument, \&c. South Sea Islands

6420 Long and elegantly shaped war club, having its whole length beautifully carved

6421 Stone war weapon, Nootka Sound ; large wicker fan, and fish hook

6422 Elegant double feather necklace, and Sundry others, Sandwich Isles

6423 Two snall war weapons, and a basaltic adze, South Sea Islands .

6424 Double cup, gourd cup, and fish hook, Sandwich Isles

6425 A curiously ornamented quiver, with arrows, Prince, William's Sound

6426 A neatly shaped ava bowl, having two grotesque figures, whose arms serve as supporters. The eyes of the figures are formed of mother of pearl, and their mouths are well furnished with teeth. In the middle of each mouth is a hole communicating with the bowl, through which the liquor is drank or poured out. It was purchased from the King of Owyhee; and is without question one of the greatest curiosities brought from that Island

6427 Bone scoop, and fishing tackle, Nootka Sound

6428 Heath-like, and two other large specimens of calcareous spar

6429 Crystallized tin, and five other specimens

6430 A fine specimen of crystallized manganese; Triers

6431 Eight various spécimens of calcareous spar

6432 Crystallized zeolite, Feroe; Franckenburg copper, and two others

6433 Calcareous spar, curiously crystallized, and tinged by manganese, Germany

6434 A very fine specimen of crystallized boracite, in the matrix, Luneburg, and a specimen of Arragon spar 
6435 Crystallized blende, and five others

6436 Three curious calcareous incrustations

6437 Two very elegant specimens of iron ore, Germany

6438 Mass of crystailized topazes, Siberia ; chalcedony, a beautiful agate, and a quartz crystal

6439 A curious stalagmite

6440 A large specimen of Pisolithus 1 -

6441 Beautifully crystallized calcareous spar, and three others

6442 Two large specimens of crystallized blende, and a large mass of white quartz

6443 Polished specimen of bacon'spar, veined agate, and five others

6444 Green zeolite, in the matrix; pearl spar, on fluor; carbonate of barytes, on blend; and argentiferous galena, Hartz

6445

6446 Silver ore ; three varieties of argentiferous galena, Sweden; and another

6447 Silver ore, calamine, tro varieties of phosphate of lead, and two others

6448 Yellow copper ore, in black shorl, rare; thread-veined and blistered copper ore

6449 Crystallized marcasite, and eleven other specimens

6450 Five good varieties of native copper, and oxyd of ditto

6451 Four various small stalactites $2 \mathrm{f} 6$

6452. Amethystine quartz, and five others

6453 Thire elegant small specimens of crystallized calcareous spar "fo

6454 A curious sparry deposition, and a stalactite

6455 Two specimens of wood-like coral, and six others

6456 Large specimen of silvery selenite, Saxony; and two hand. some biendes

6457 Three variously crystallized calcareous spars, and another

6458 Fifteen various polished specimens of fluor, and a specimen of Scotch marble

6459 Two fine specimens of Florentine marble $/ \mathrm{s}$

6460) A remarkably fine and large slab of Cottam marble

6461 A capital collection of modern and ancient marbles, containing many of extreme beauty and rarity, the slabs are cut and polished, and one hundred and eighty-seven in number.-These specimens are respectively numbered and described in the former catalogue

6462 Twenty-four various specimens of fluor, cut and polished, and seventeen marbles, ditto 2 .

6463 Five large specimens of brocatelli and other fine marbles, and seven others

6464 Thirty-seven beautiful polished specimens of ancient and modern granites, porphyries, and serpentines 2 
6465 A fine specimen of crystalized realgar, on native arsenic, Saxony

6466 Two iron ores, Triers; pearl spar, and calamine

6467 Six small specimens, including plumbago, from Cumberland, \&c.

6468 Delicate white calcareous spar, purplish fluor, and tea others

6469 Ruby blende, crystallized tin, Swedish copper ore, and three others

6470 White oxyd of manganese, very rare, and green oxyd of nickel

6471 Curious sparry incrustation, formed on an aqueduct, another: ditto, and three vegetable incrustations

6472 Crystallized ruby silver, and three others

6473 Octohædral iron ore, Corsica; gold-coloured hæmatite, and two others

6474 Crystallized blue carbonate of copper, Siberia; and native and vitreous copper

6475 A fine specimen of solid grey cobalt, Hesse

6476 A very choice and large specimen of auriferous pyrites, or Piedra d'Inca

6477 A specimen of nutive zron, from Senegal $1=2-0$

6478 Red oxyd of lead, filling the cavities of a decomposed almond stone-recently discovered in Hesse 44

6479 Phosphate of lead, in large and fine crystals, Saxony

6480 A very capital and finely crystallized carbonate of uraniuma

End of the Fifty-fourth Day's Sale. 


\section{FIFTY-FIFTH DAY.}

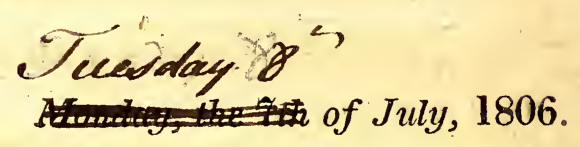

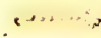

2

6481 AN ingeniously ornamented belt, and another, made by North American Indians

6482 Two richly ornamented African caps

6483 Two sleeping stools, and a double meat dish, Otaheite

6484 A large and handsome sleeping stool, from ditto

6485 Paddle, Nootka Sound

6486 Long war club, Friendly Isles

6487 Bow and arrows, Nootka Sound

6488 Barbed speai, made of beautiful mahogany-like wood, Sandwich Isles

6489 A very long spear, from ditto

6490 Ornamented pouch, and belt of the North American Indians

6491 Ditto, ditto, of different pattern

6492 A curiously ornamented leathern pouch, made by ditto

6493 Head-dress of North American chief, and two others

6494 Curious stone war-weapon, and fish hooks, Nootka Sound

6495 Wooden bowl and dish, and sundry fish-hooks, Sandwich Isles

6496 Three vegetable cups, a comb and fish-hook, South Sea Isles

6497 Long war-club, Friendly Isles

6498 Two stone war-weapons, Nootka Sound; and an instrument for throwing spears

6499 A very singular war-club, New Caledonia 
6500 Copper plate engraving of twenty-seven ancient alphabets, framed and glazed

6501 Copper-plate engraving of Queen Elizabeth's Funeral Pro. cession, copied from the original in the British Museum

6502 Curious cap, from Tshukutski Noss; and two pouches, Prince William's Sound

6503 Bracelet, from ditto; a large tattooing instrument, \&c.

6504 An elegantly formed war-club, Friendly lsles

6505 Richly carved ditto, from ditto

6506 Curious squirrel-skin girdle, Onalaski

6507 An extremely beautiful long barbed spear, formed of mahogany-like wood, Sandwich Isles

6508 Green and scarlet feather helmet, and two feather ornaments, from ditto -

6509 Long war-club, from ditto

6510 A handsome bone scoop, and fishing tackle, Nootka Sound

6511 Cloth-beater, and sundry others, Otaheite

6512 Large comb, from ditto; and feather necklace, Sandwich Isles

6513 A curious wooden eloth-beater, Otaheite; and an instrument to pound bread-fruit paste

6514 Elegant feather necklace and sundry others, Sandwich Isle*

0515 Basaltine adze-head, sinall dagger, \&c. from ditto

6516 Model of white bear, carved in bone, Nootka Sound; and bird's head mask

6517 Beef, which formed part of the ship's store of the vessel, in which Lord Anson circumnavigated the globe

6518 War-weapon, King George's Sound; hemp-beater, Otaheite; and two others, from New Holland

6519 A variety of ornaments and instruments, from the South Sea Islands and Nootka Sound

6520 Curiously ornamented garters, and bird decoys, Kams. chatka; and two lip ornaments, Prince William's Sound

6521 Handsomely ornamented boots, Kamschatka

6522 Foul weather frock, made of whale's intestines, Nootka Sound

6523 Curious bracelets, and a variety of other articles from the same place

6524 A variety of curious seed vessels, \&c.

6525 Various samples of fine tea

6526 A large piece of the legatto bark, and a portion of the treo

6527 Rose of Jericho

6528 A small lizard, and a snake, New Holland-two cases

6529. Cyclop kitten, and a mouse-twe cases

6530 A very fine specimen of lacerta Siren, partially dissected for the purpose of exhibiting the internal structure

6531 Three curious snakes, New. HoHand-three cases

6532 A fine specimen of Lemur.tardigradus 
6533 Two curious fishes, in a large bottle

6534 Jemur nongooz

6535 Woodchat and rice bud-two cases

6536 Black-hraded emberiza, and brown African linnet

6537 Two larg' "spiders in a bottle, and two curious nests fabricated by spiders

6538 A large and fine piece of camphor wood, richly impregnated by camphor

6539 Sample of African and American rice, \&c.

6540 Sundry curious seed vessels, and fragments of gums, \&cc.

6.541 Sundry others

6542 Skeleton of the Winter cherry under a bell glass

$65+3$ A fine specimen of the steeple fungus under a glass

6544 Several large fungusses, \&c. \&c.

6645 Specimens of cowhage on the pod, camphor wood, and sundry seed vessels

6546 Gum ignot, Gum Senegal, \&c.

6547 Large nut of African white tamarind, another large nut, and various others

6548 A fine and full-grown specimen, of India corn on the stem

6549 Crystallized manganeze. Ilefeld; and antimony, Tuscany

6550 ive various calcareous incrustations

6551 Red oxyd of lead filling the cavities of a decomposed mandelstein, recently discovtred in Hesse

6552 Three large specimens of calcareous spar

6553 Eleven polished specimens of fluor, and fifteen various polished marble, \&c.

6554 Ten polished fluors, and twenty-eight polished slabs of foreign marbles, \&c. \&c.

6555 Ninety-seven ancient and modern beautiful specimens of marble, \&c. cut and polished

6556 Seventeen beautiful polished specimens of ancient and mo-

dern granites, porphyries, and serpentines

6557 A handsome slab of Florentine marble, framed

6558 Crystallized tin, chalcedony, peacock coal, and eight other specimens

6559 Two finely crystallized calcareous spars

6560 Six varieties of ditto 7

6561 Two specimens, richly coloured by manganeze, Germany

6552 Wood-like coal, pitch coal, and six others

6563 Three beautiful cut and polished varieties of the great Le. verian sardonyx

6564 Emerald, and crystallized topaz

6565 Chrysolites, Brazilian topaz, Saxon ditto, and amethyst

6506 Three specimens of adamantine spar

6567 A variety of small mochos and agates

6568 A crystallized octohredral diamond 
6569 Lesser Bonana bird

6570 Sparrow variety

6571 Troupial oriole

6572 Picus pubescens

6573 Variety of the titlark

6574. Undulated olive noodpecker

6575 Black-breasted loxia

6576 Black-headed loxia, m. and fem.

6577 Golden-winged woodpecker

6578. Loxia sanguinirostris

6579 A curious merops, from the South Seas

6580 Certhia cærulia, var.

6581 Rice bird

6552 Black-billed guillemot

6583 Wren, Gibraltar; and canary bird, m. and fem. - two cases

6584 Least grebe

6585 Buff-breasted thrush, Brazils

6586 Pacific parrot var.

6587 Yellow-winged creeper, New Holland

6588 Oriolus Mexicanus

6589 Tanagra tatao, var.

6590 Alcedo sacra

6591 Squirrel monkey

6592 Tanagra tatao, var.

6593 Certhia cærulia, var.

6594 Small-belted kingfisher

6595 Pit wren

6596 Shoveler duck, m. and fem.

6597 Alcedo galbula

6598 Blue and black certhia, Brazils

6599 Green Shanks

6600 Mandarine duck, female

End of the Fifty-fifth Day's Sale. 


\section{FIFTY-SIXTH DAY.}
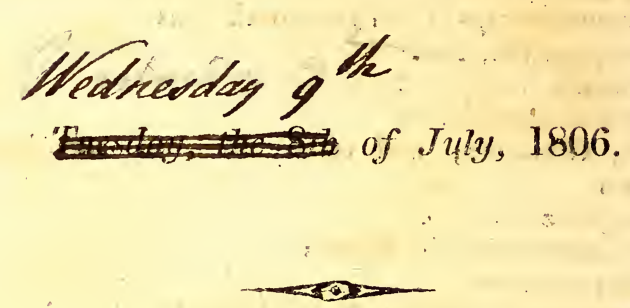

$6601 \rrbracket$ WO cocoa-nut bottles, New Zealand

6602 Mandarine's fan, and a scratcher

$6603 \mathrm{~A}$ pouch, and two others, made by the North American Indians

6604 An elegant bead pouch, and a pair of bracelets made by ditto

$6605 \mathrm{Knife}$, and elegantly ornamented knife case of ditto, and a small porcupine quill ornament

6606 Tortoiseshell bracelet, singular neck ornament

6607 Shell necklace, and another braçelet, South Sea Islandș

6608 Two spears

6609 Two swords

6610 Five various daggers, and a malay creese

6611 Brush made of spun glass, Chinese padlock, and two others

6612 Chinese scales, a scratcher, a padlock, \&c.

6613 Two curious swords

6614 Basaltic adze, Otaheite; and war club, N, America

6615 An elegant small French sword, and a remarkably large knife

6616 War club, Friendly Isles

6617 Three various weapons, \&c. from ditto

6618 Curious Chinese sword and scabbard, and another

6619 Singular war club, New Caledonia

6620 Carved war club, Friendly Isles.

6621 Ditto, Otaheite 
6622 An extremely beautiful bead pouch, made by the North American Indians

6623 Another, made of porcupine quills

6624 Head-dress of a North American chief; ornamented stick of ditto, and sundry others

6625 A very fine double cocoa-nut

6626 A variety of curious Chinese manuscripts

6627. Six volumes in the Chinese language

6628 Six others

6629 Seven others

6630 Seven ditto, having curious outline drawings

6631 Chinese Tragedy, with curious illustrative designs

6632 Curious sleeping-stool, Otaheite

6633 A Genton manuscript, a Chinese padlock, and another

6634 Curious Chinese chain carved out of solid wood, a Chinese almanac, and sundry others

6635 Snow-case for the eyes, and a curious box

6636 Impressions of monastic seals, and sundry cthers

6637 A curious and fine specimen of penmanship, by Matthew Buchinger, lorn without hands or feet

6638 Two curious long war-weapons, Sandwich Isles

6639 Long barbed spear, formed of beautiful mahogany-like wood

6640 Long spear, formed of similar wood, Sandwich Isles

6641 Sundry curious fish-hooks, and a fan, South Sea Isles, \&c.

6642 A singular and handsome carved patapatoo, New Zealand

$66+3$ A very beautiful and highly finished patapatoo, formed of dark green porphyry-like stone

6644 Curious war-weapon, Nootka Sound; model of a canoe; comb, \&c. Otaheite

6645 Basket, and fan, made of wicker-work, Sandwich Isles

6646 Elegant feather necklace, minute idols, and sundry other; from ditto

6647 Dagger, shark's tooth instrument, \&c. from ditto

6648 Long richly ornamented dagger, from ditto

6649 Adze head, made of basaltes, from ditto; and cap, Nootka Sound

6650 Bone patapatoo, from ditto; and sundry others

6651 Curious instrument from citio

6652 Feather necklate, comb, \&c. S. Sea Istands

6653 Dancing rattle, small adze, ixc. from ditto

6654 Curious dancing mask, Nontka Sound

6655 Beef, which formed part of the ship's stores of the vessel in which Lord Anson circumnavigated the globe

6656 Certificate of a person having seen the Holy Sepulchre, wheat fonnd under a Roman pavement at Colchester, and sundry others 
6657 Sundry imitations of fruit, \&zc.

6658 Part of an elephant's tusk inclosing a brass ball, a ditto inclosing an iron ball, and another

6659. Varinus iron nails, \&c. found in the stomach of an ox, iron hoop, found imbeddid in the solid body of an oak, and five other sundries

6660 A curious preparation of the cranium, \&c. of an infant

6661 Seven various coneretions, \&uc. from the bladders and stomachs of quadrupeds

6662 Seven ditto, and two spirit preparations

6663 Skeleton of a human fcetus

6664 Three remarkably large concretions, and sundry others

6665 Seven ditto, various

6666 Part of an Egyptian mummy, and sundry others

6667 Chicken with four legs, and another

6668 Eight various concretions

6669 Fourteen ditto

6670 Kitten with eight legs, and two others

6671 Six various foetusses

6672 Hare, cat, rats, wc. found starved

6673 I wo cats, and two rats, ditio

6674 Preparations of the human rengue and ar, and two others

6675 Three various spirit preparations

6676 liemarkable cuticle of the human hand, and a case, containing several cow balls

3677 A beautifully preserved and delicate female hand. presen2. - - ted to Sir Ashton Lever, as the Hand of Fair Rosanond

6678 Corneous excrescence, said to have proceeded from the human head, and a horny substance formed on the head of a fowl 2.5

6679. Scull and lust:s of the sen-cow

6680 Ten polished finors, and nine ditio specimens of marble

6681 Two handsome slabs of Florentine narble/3

6682 Seventy-five various polished specinens of ancient atd modern marble, $4 c \cdot 2,-50$

6683 Fonrteen beantiful polished specimens of ancient and modern porplyries, granites, and serpentines / $03-0$

6684 Nineteen vari us dito, including some marbles $/ \cdot 3 \cdot 0$

6685 A large slab of Cottarn marble

6686 Coal, red jaspar, volcanic glass, \&c. rrom New Holland

6687 Two large specimens of crystallized calcareous spar 8

6688 Large and fine ditio of heath-like spar $1 /=6$

6689 Carbonate of barytes, and three crystallized blendes $/$,

6690 Twelve small specimens, chiefly calcareous 10

6691 Three large specimens of calcareous spar 12

6692 Several curious small specimens of Franckenberg copper ore, resembling corn heads $/$ : 
6 6.3 Eight various calcareous incrustations

6694 Red oxyd of liad filling the cavities of a decomposed mandelstein, recently discovered in Hesse

6695 A very curious specimen of the same kind of stone, having in its cavitie's oxyd of lead and metallic lead, from the same piace 1 tho is $-6-1)$

6695 Sundry curious exotic seed vessels, \&c. $>b y=6$

6697 A fine specimen of camphor-wuod richly impregnated with camphor

698 Vegetable lamb, and sundry curious barks, \&c.

6099 A wariety of curious branches of exotic trees, \&c. 8

6700 A specimen of camphor-wood, similar to Lot 6697

6701 A beautiful red Isis, and a variety of other curious corals, \&c. 4

6702 A fine specimen of madrepora interstincta

67 3 A branched madrepore, and a millepore

6704 A very elegant specimen of mactrepura gyrosa

$6705 \mathrm{~A}$ beautiful and large specimen of scarlet Isis, having a curious mille pore, serpula, \&c. attarhed to it $/ 2$

6706 A large West indian conch, iemarkable for having pieces of coral, \&c. naturally attached to it

6707 Three large corals 6.6

6708 Madrepora gyrosa, madrepora carduns, two curious sponges, and one other 4

$6709 \mathrm{An}$ extrumely beautiful and curious madrepore $s-6$.

67.10 Six various specimens of coral, \&c. $4-1$

6711 Seven ditto

6712 A curious Alcyonium formed on an ald starstone, from the E Inilies, Alcyonium pulmonaria = "s

6713 A large and fine cup-shaped madrepore

6714 A large millepore 2

$6715 \Lambda$ variety of specimens of gorgonia., \&x.

6716 A large and beautiful specimen of sis bippuris, with millepora cærulea atlatched to it $/ 3$

6717 Sundry curious small specimen, of coral -6

6713 Madrépora Dædalea, a lerge and fine specimen

6719 Madrepora carduus, naturally attached to a fragment of rock, and another

6720 Ditto, naturally attached to a piece of earthenware; a gorgonia verucosa attached to a pinna, and three others

$670 *$ Six curious sponges, and two cutale tish bones

$6711^{*} \mathrm{~A}$ highly beautiful specimen of lace millepore, attached to

1 - 1- group of serpulæ; a ditto, affixed to a white anomia

$6712^{*} \mathrm{~A}$ handsome specimen of starstone coral

6713* Several elegant small specimens of coral 
$6714 * \mathrm{~A}$ capital specimen of the broad flat variety of madrepo:a muricata, with slender short branches, E. Indies 1. firts

$6715 *$ A most elegant scarlet gorgonia, naturally affixed to a stone. This specimen is of the most uncommon beauty and perfection

$6716 *$ Three varieties of the great Leverian sardonyx, cut and polished

-6717* Sundry small mochos, \&c cut and polished

6718*An oval polished specimen of the Leverian avanturine 6719* Topaz, cut and polished, and one in its crystallized state 6720 Emerald, chrysolite, amethyst, cat's eye, and two crystalli-, zed varieties of the Brazilian topaz

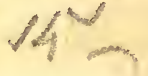

End of the Fifty-sixih Day's Sale. 


\section{FIFTY-SEVENTH DAY.}

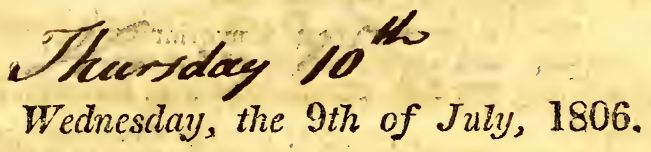

6721 I EATHER necklace, and sundry others, S. Sea Islands

6722 Curious dancing rattle, Nootka Sound; and sundry others

6723 Curious war weapon, from ditto; and cloth beater, Otaheite

6724 Two sleeping stools of different construction, from ditto

6725 Barbed spear of beautiful mahogany-like woou, Sandwich Isles

6726 Club, New Caledonia; and carved whalebone club, Nootka Sound

6727 Carved war club, Friendly Islands

6798 Two paddles; from ditto

6729 Small model of a canoe, Esquimaux; two small bags of pigment, used by way of ornament by the natives of Nootka Sound; feather necklace, and comb, Sandwich Isles, \&c.

6730 Bone patapatno, Nootka Sound; model of canoe, and fishing instrumeut, \&c.

6731- Basaltic adze head, bone rattle, and another, Nootka Sound

6732 Two sleeping stools of different construction, Otaheite

6733 Two war clubs, Friendly Islands

6734 Curious cap, Nootka Sound, formed of a quadruped's skim, and human hair

6735 Curious long war club, Friendly Islands. This club is in an unfinished state, and exhibits the notches and outlines intended for future carving

6736 War club, curiously carved with figures \&c. from ditto

6737 Curious war weapon, Nootka Sound; and cloth beater, Otaheite

6738 A double meat dish, and a small sleeping stool, from dito

6739 A long barbed spear, formed of beautiful malogany-like wood, Sandwich Isles 
6740 Three feather necklaces, and sundry others, S. Sea Islands

6741 Long war club of singular form, from ditto

6742 Ditto carved, from Friendly Islands

6743 Handsome polished dagger, an idol, small bowl, and two feather necklaces, Sandwich Isles

6744 Four various lip ornaments, Prince William's Sound

6745 Wooden can, and a pouch, Nootka Sound

6746 A curious long war club, ornamented with feathers,'Friendly Islands

6747 War-club, ornamented with the pearly part of a shell

6748 Two curious lip ornaments, \&c. Prince William's Sound; and an idol, Otaheite

6749 Long and finely carved war cketb, Friendly Islands

6750 A very singular and beautifully carved ditto, from ditto

6751 Horn scoop, Prince William's Sound; a pouch, and necklace

6752 Head ornament made of feathers and beads, from ditto; a handsomely carved scoop, and another

$6753 \mathrm{~A}$ small and very curious figure, exhioiting the peculiar dress (including the rose and lip ornaments) of an inhabitant of Prince William's Sound, together with two lip ornaments

6754 Squirrel skin hood, and a pair of gloves, Cook's River

6755 Skin of sea otter, Nootka Sound, being one collected by Capet. Cook on his last woyage

6756 Quiver for arrows, and boue braier to ditto, from $T$ shus kutskinos, on the N. E. part of Asia. This article is a work of great curiosity, being ornamented with porcupine quills, squirrel skin, ermine, \&c. is said to be the only specimen of the kind brought to Europe 9-6

6757 Three curious exotic plants, and a large seed yessel s

6758 Carved calabash, and three bark boxes

6759 Two tays of cuious seed ressels, $8 c .86 .56$

6759 Twu trays of curious seed vessels, \&c. \&c.

6760 Ditto,

$$
\text { ditto }
$$

6761. A large and fine specinen of camphor wood, richly impregnated with camphor of - 6

6762 Vegetable lamb, lagatto bark, a large seed vessel, \&c. 106

6763 Franckincense, clove, bark, nutmegs, 8c. 10

6764 Two curious bird's nests, \&c. $3-6$

6765 Eleven polished specimens of calcareous spar

6766 Fluor, sprinkled with marcasites, \&cc. crystallized blende, and two calcareous spars / 3 .

.6767 Four various blends, specimen of the Gibraltar rock, and another 4

6768 Two finely crystallized calcareous spars, and another

67.69 Six calcareous incrustations, including a bird's nest, and a small stalactite 2 -

6770 Schiller spar, Hartz; crystallized tin, and eight others $z$ 
6771 Group of denticular spar, and three others

6772 Four various stalactites, and an incrustation

6773 Three large specimens of calcareous spar

6774 Octohædral iron ore, and several other crystals, and two cards cont ining iron sand, from Ameriea

6775 Four curious incrustations

6776 Veined carnelian and eleven others $/ /-6$

6777 An extremely delicate specimen of light green eopper malachite, in small bubbles, from Siberia

6778 Argentiferous galena, from the Hartz, and varions others

6779 A large and capital specimen of decomposed mandelstein, having many of its cavities filled by red oxyd of lead, and metallic lead, necently discovered in Hesse $1-13-10$

6780 A fine specimen of rose-coloured calcareous spar, in primitive rhombs, very rare, Hesse / is

6781 Native copper in chaik, Siberia, very.rare; red oxyd of lead, mica in an hexagonal colamn, and various' other curious small specimens $/ /-6$

6782 Wood in an early stage of transformation into coal; and. coal retaining the ligneous structure, Hesse $/-7-\infty$

6783 Columnar coal and pitch coal, Hesse

6784 Sundry small ornamental mochos, \&c. cut and polished $/ 5$

6785 Ditto, ditto / / 40

67:86 Three cut and polisherl specimens of the Leverian sardonyx, one ditto of the Leverian avanturine, a chrysolite, a topaz, \&xe:

6787 Sundry small mochos, \&c. cut and polished $/ 2.0$

6788 Emerald, chrysolite, Leverian avanturine, topazes \&c. $1-14=0$

6789 Five brilliant varieties of selenite; Germany

6790 Crystallized aqua marine, two ditto topazes, and toarmaJine

6791 Sundry small polished mochos, \&c.

6792 Emerald, chrysolite, and three : methysts

6793 Two beautiful specimens of native gold, Hungary -

-6794 Two yellow and one purple crystalizec topaz, Brazil: a double-pointed crystal, inclosing titanium; and a Saxon topaz $1 /-6$

6795 Schiller spar, Hartz; and five others

6796 A chrysoprase seal, and a specimen of the Leverian sardo- $-7-3-$ ny $x$, having an opake white vein crossing it -

6797 A brown glass compesition, having a remarkable blue lustre, and a polished specimen of wax opal

6798 A fine cat's eye, and a chrysolite

6799 Sundry' sm polished mochos, \&c.

6800 Crystallised aqua marine, tourmaline, and topaz

6801 Ruby, cut and polished, Saxon opal, topaz and chrysolite

6802 Crystal of adamantine spar, and a large topaz

6803 Two amethysts, two topazes, and chrysolite 
6804 A small but fine oriental ruby, ditto crystallized, emerald, two amethysts, a turquoise, and a beautiful small moon stone $1 \cdot 12=0$

6805 A fine cut aqua marine $-1=1-6$

6806 Star stone : $\quad \mathrm{ta}$ a

6807 A very fine moonstone

68:18 A ditto sun stone, extremely rare

6809 Several fine varieties of the topaz, and three others

-6810 A very fine noble opal
6811 Five brilliant specinens of selenite, Hungary

6812 A beautiful specimen of foliaceots native gold, Hungary!

6813 Two beautiful specimens of ditto / / / $/ \mathrm{w}-3$

6814 A fine columnar crystal of mica, Moravia; native gold, arseniate of copper, nickel, \&c.

6815 A most capital and finely crystallized specimen of realgar, Hungary

6816 A fine slab of Spanish avanturine

6817 An extremely delicate specimen of flcs ferri -6

6818 Missel thrush and snipe-two cases 5

6819 White yariety of the swallow

6820 Young land rail, and wren, two cases

6821 Cardinal grosbeak

6822 Sinall grebe, and sandpiper

6823 Gull, N: America

6824 Ruby-crested finch

6825 Red-tail, $\mathrm{m}$. and $\mathrm{fem}$. and another, two cases

6826 Variegated blue tanager, under a bell glass

6827 Jackdaw, and an unfeathered toucan-two cases

6828 A fine specimen of the cormorant, witbout case

6829 Squirrel morkey, and another, two cases

6830 Bastard baltimore bird, and another, iwo cases

6831 Fire-eyed grebe, $\mathrm{m}$ : and fem.

6832 Swallow, m. and fem. and eggs with the nest, curiously constructed in the wing of an owl. The owl was suspended in a barn by a packthread, so loosely as ta be moved by the least blast of wind

6833 Yellow. crested cockatoo

6834 Curious brown thrush, S. Seas, m. and fem.

6835 A beautiful whitish variety of the lark

6836 Brown speckled emberiza, $m$. and fem.

6837 Nuthatch

6838 A curious yariety of the bulfinch, and a specimen of the common bulfinch-two cases

6839 A fine specimen of the Surinam butcher bird

6840 Yellow eared seal, extremely rare, S. Seas

- End of the Fifty-seventh Day's Sate. 


\section{$A \mathbb{P} \mathbb{E} \mathbb{N} \mathbb{I}$}

To

\section{THE SALE}

OF THE

LEVERIAN MUSEUM. 



\section{APPENDIẌ.}

\section{FIRST DAY.}

\section{Monday; the 14th of July; 1806.}

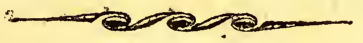

1 HocLoî̀ tube, for dischararging arrows, Ȧficas

2 Two singulär weapons, Nootka Sound; and an adze

3 War-club, Friendly Isles

4 Carved ditto, from ditto

5 A nother of very singular shape

6 Sundry feather and shell necklaces; \&c. Sandwich Isles; and Canadian ornaments

7 Nephritic-stone chissel, and part of a carved cocoa-nut

8 A large and fine specimen of jaspideous wood, from Swindor

9 Two handsome paddles, Friendly Isles

10 The iridiscent oyster, Guinea; and three others

11 Cardium unedo, the antique purpura, and four others

12 Mactra lutraria, a scarce buccinum, and four others

13 Two long war-clubs, Friendly Isles

14 Two short ditto

15 A short carved ditto, from ditto

16 Sundry feather and shell necklaces, Sandwich Isles; and cus rious Canadian ornaments

17 An ancient painting on lapis lazuli

18 A short paddle, and another, Friendly Isles

19 Feather and shell necklaces, and combs, S. Sea İslands

20 Small sleeping stool, Otaheite; one end being made to operate as a dish

21 A very handsome and curicus necklace, ornamented with shark's teeth, Sandwich Isles 
22 A variety of necklaces, \&c. S. Sea Isles

23 War-club, New Caledonia

24 Curiously carved ditto, Friendly Isles

25 An extremely beautiful carved war-club, from ditto

26 Sundry curious necklaces and combs, Otaheite

27 A scarce tun, the brunette cockle, and four others

28 The great volute, New S. Wales, and a large spider shell

29 Black club the asperated frog, and seven others

30 Mytilus rusticus, a large oriental pecten, and two others

31 The duck's bill patella, an orange gryphus, and four other shells

32 The Arabian spindle, a large lineated buccinum, New S. Wales; and a large magpie shell

33 Two bat volutes, a striated ear, and six others

34 Tellina fausta, a pig's snout buccinum, and four others

35 A scarce pectunculus, and a turbo, Vun Diemen's Land; an oval mya, Brazil; and three others

36 Cardium costatum, the red spondylus of Guinea, and two others

37 Fourteen polished stones, including red, white, and fleshcoloured fortification agates, pudding-stone, Herefordshire; oriental stones, \&c.

38 Singular spathose iron, Wales; resin tin and chalcedony, Cornwall; native vitriol, Anglesea; and five others

39 Zeolite in hexagonal plates, Stafia; green phosphate of lead, Scotland ; irnn, malachite, 8c.-six specimens

40 Tellurium, or graphic gold, Transylvania ; opal in the ma. trix, garnets in mica, Vesuvius; sandstone crystallized, Fontainbleau ; foliaceous iron ore, Tuscany ; and copper, Germany_six select small specimens

41 Six minerals, various

42 A fine polished mass of hæmatite iron, and a denticular spar, North Wales

43 White lead crystallized, galena in truncated tubes, elbe iror, cobalt, Scotland, \&c.- - eight specimens

44 Rose quartz, Hungary ; a fine arseniate of copper, Cornwall ; thread-veined galena in cauk, and three others

45 Eight minerals, including a calcareous spar in the hollow of 2 palatinate agate; white lead, Scotland; arseniate of copper, marcasites, \&c.

46 Barsolenite in large tabular crystals, Hartz; crystallized white lead, galena with fluors, \&zc.

47. Plumose zeolite in trap, from Sky; purple cubic fluor, in small cubes, Derbyshitre; a carbonate of lead, and a galena

48 Octohedral marcasites, Bath; crystallized blend, Durham; an argentiferous antimony, Schemnitz; and part of a hol: low ferruginous ball, lined with quartz, Gloucestershire 
49 Fasciculated asbestos, New York; sulphate of barytes, Hartx; an oriental onyx, and six others

50 Ribband jasper, Siberia; three correlians, Falkland Island; green jasperified fossil wood, with green crystallized quartz, Bohemia, rare; an oriental agate, a sardonyx, and two other silices

51 A beautiful specimen of the iridescent feldspar of labrador, polished

52 Carbonate of copper, Siberia; white actynolite, Tyrol ; serpentine stone, Scotland; crystallized galena, Freylerg; and five others

53 Pointed rock crystals, frosted with a curious calcareous spar, and coating denticular spar

54 Garnets in micaceous shistus, Scotland; and dark ditto in basalt, Etna; black oxyd of manganese crystallized, Aberdeenshire ; heath-like spar, Gloucestershire ; \&c.-eight specimens

55 Cubic fluor, formed on a fine group of denticular spar

56 Impression of a pine cone, exhibiting part of the stem and lateral leaves - a curious specimen, and seven other vegetable remains in iron and coal slate

57 Sharp impression of a fern in iron stone, Colebroke Dale; ditto in coal slate, of curions lubate leaves, \&a.- - six specimens

58 Wood with spar, jaspideous wood, wood perforated by toredines, recent and fossil; jet-like fossil wood intersected with barytes, rare, forming a series of fifteen woods, chiefly fossil

59 Eight fossil plants, exhibiting impressions of five distinct kinds of leaves

60 Multibate fern leaf in iron stone, and five other fair impressions of plants

61 Curious recent palate of a fish, bufonites similar to the fossil, and a very singular aggregation of bone-No. 25 former catalogne

62 Parts of fossil bufonites, palates, Stonsfield, rare; marl impressed on one side with a large portion of a fish, and on the other a similar impression of another, with vertebral bones remaining, Banks of the Euphrates; and other curious petrifactions

63 Coal slate impressed on one side with a large and singular ramose plant, ciliations of small leaves and several nuclei, and on the other with small branches apparently of the same plant-a highly interesting specimen

64 A vcry curious bark in coal slate, distinct impressions of leaves resembling the elm and rose, and three other vegetable remains 
65 A clear impression of a fish in Papenheim marl, and seven specimens of echini, spines, $\$ c$. chiefly chalk fossils

66 Singular striated leaves, two ferns, and a pine-head tossil

67 Three impressions of fossil plants

68 Five ditto, one a singular ramose plant, shewing six branches originating from the main stem with deeply lobate leaves, and four other petrifactions

69 Fossil plants, various, chiefly from Yorkshire, and two others go Fragments of five teeth of an alligator, with part of the jaw atiached, Bath; and another ditto singular tooth, Oxford; sharp impressions of two parts of fishes found by Mr. Douson on the banks of the Luphrates; and another

$70^{*}$ Cardium variegatum, the bason tellen, and seven others

71 A scarce tun, New S. Wales; two ears, and three others

72 The sulcated sun, New Zealand; and a scarce alatus

73. Mya pictorum, murex despectus, and four others

74 A scarce pecten, Van Diemen's Land; and an uncoated Iris ear

75 A carrier, a Medusa limpet, and four others

76 Four curious medals impressed on tortoiseshell, and a head of old Parr, in ivory

77 A pair of singular spurs, Burbary; a wooden shoe, France; and a Malay cresse sheath

78 A singnlarly shaped patapattoo, and a matted belt, New Zealand; and a matted sun shade for the face, Friendly Isles

79 A large Roman tile ornamented with the head of a woman, found in digging a gateway, in the mint, Southwark

80 A curious lusus naturæ, the bust of a philosopher, formed by the veins in a piece of walnut-tree wood

81 Virginian nightingale, and yellow hammer-two cases

82 White owl, Strix flammea, and young

83 Green woodpecker

84 Buff-breasted hawk, North America

85 American nuthatch, and cock goldfinch

86 Black-headed bunting, $m$. and fem. America

87 Brown water-rail, South Seas, and another rail.

88 Red-headed woodpecker

89 Spanish duck

go Brown cuckow, Cayenne, and red-headed woodpecker, without case

91 Blue-headed lory, water rail, and small snipe, ditto

92 Little woodpecker, picus minutus, scarce

93 Black-toed gull, rare

04 Glossy ibis, tantalus falcinellus, rare

95 Procellaria capensis, pintado petrel, Isle of Desolation

96 Stratulated granite, Scotland; fibrose green carbonate of copper, Moldova in the Bannat; a mammillated spar, and three others 
97 A large rhomboidal selenite, Oxfordshire; and a green veined serpentine stone, from Bamiffshire, Scotland

98 Heliotropiuın, from Arabia, a blue carbonate of copper, a tin ore, stalactitical spar, and four others

99 A rare Caledonic septarium, from Tuscany; crystallized iron ore, from Elbe; and a polished spar

100 A polished slab of labrador feldspar

101 Tubular coral in limestone, and two masses of encrini, Derbyshire; a large echınus galeatus, a cast in flint of another of the same species, and a specimen of silicious fossil wood

102 A gryphites oyster, part of a tortoise asterias, two cordated echini, a distaff, and other fossil shells, \&c.

103 The marbied uriental pecten, the Chinese spindle, and four others

104 A fine pheasant turbo, New S. Wales; a scarce triplex, a rare colus, and three others

105 A bishop's mitre, two alatæ, and three others

106 The basket clam, a stellated balanus, conus miles, and three others

107 A large and fine compass pecten

108 A large green and pearly snake shell, from China

109 The lineated buccinum, New S. Wales; the tuberculated alatus, and four others

110 A small nautilus Pompilius, the conic bronze limpet, a young bull's mouth helmet, and three others

111 Black hæmatite iron ore, in large stalactites, Triers; a group of selenites, Oxfordshire ; and denticular spar, Derbyshirc

112 Appatite, Schalackenswald, Bohemia, rare; red zeolite, Dunbarton, scarce; and grey silver ore, Saxony

113 An interesting group of crystallized phosphorescent blend, on white quartz, Capuic

114 Green oxyd of copper sprinkled with blue, on a ferruginous matrix. Bannat; yellow sulphate of barytes in long crys. tals, and an iridescent foliated iron ore, Elbe

115 Green emerald fluor, Cornwall

116 Native oxyd of bismuth, aggregated with pink arseniate of cohalt, and green oxyd of nickel, rare; grey silver, Saxony; iron ore, Wales; and sulphate of copper, Mona mine

117 Blue crystallized malachite, Moravia-a very fine specimen

118 Chromate of lead, Siberia, rare; deep-coloured amethystine quartz in agate, Bohemia, and another

119 Rich velvet iron ore, Glamorganshire-a very fine specimen

120 Capillary bismuth, an extremely fine specimen

$110 *$ Sulphate of strontian, Clifton; a beautifully crystallized iron; sulphate of copper, Mona; and a large crystal of amethystine quartz, Bohemia 
$111^{*}$ Fine spathose iron ore, South Wales, rare; arborescent native silver in the matrix, Hungary; and oxyd of copper with lead and calamine, Scotland

$112^{*}$ Native sulphur in the matrix, Spain ; yellow and white sulphate of barytes ; and foliaceous iron, Elbe

$113 *$ A very complete series of Continental marbles, serpentines, and other stones-cut and polished

114 Sulphate of barytes, of a brilliant topazine colour, crystallized in large prisms-a specimen of exquisite beauty

$115^{*} \mathrm{~A}$ capital group of rock crystals, intermixed with laminated purple cubic fluor, and marcasites containing tungstein

$116 *$ Purple fluor mixed with fragments of encrini, rare, from Derbyshire; ribband jasper, Siberia; cubic fluor frosted with brilliant crystals of quartz and spar, Durham; and a pyrites

$117 \times$ Two specimens of silicious fossil wood, a scarce red otiental jasper, an Arabian agate, and a box "formed of pudding stone

118 Two cones two patellæ, a New Zealand ear, and four other shells

119*Three corallines, the tape and two other millepores, ân Isis hippuris, a specimen of red coral, and two others

$120^{*}$ A scarce brown triplex, Tranquelar; an unicorn 'scoop, a black scoop, and nine other shells

End of the First Day of Appendix. 
APPENDIX:

\title{
SECOND DAY.
}

\author{
Wesnessory \\ Tuent the 15th of July, 1806.
}

121 ConicAL cap, Nootka Sound; and part of an African musical instrument, formed of snakes skin, \&c.

122 Sleeping stool, Otaheite

123 Feather and shell necklaces, Sandwich Isleg; and sundry ornaments of North American Indians.

124 A pig in armour, and a Guana lizard

125 Two long war-clubs, New Caledonia

126 A carved ditto, and another, Friendly Isles

127 A beautifully carved ditto, from ditto

128 A great variety of shells of different genera

129 The deep pecten of Providence Island, an uncoated trochus, and a turnep sheil

130 The duc cone, a lineated rhombus, an uncoated Iris snail, and various other shells

131 Two curious long war-clubs, Friendly Isles

132 Another of singular shape

133 A carved ditto

134 Feather and shell necklaces, combs, \&c. S. Sea Isles

135 Head of a ram, with three horns

136 War-club Friendly Isles

137 A long ditto, from ditto

138 A ditto, frotn New Caledonia

139 A partridge tun, a scarce murex, and four other shells

140 The brown star limpet, a devil murex, and ten others

141 The pyramid trochus, the yeliow knobbed fig, and two othere 
142 Long war-club, Friendly Isles

143 Another of similar shape, but finely carved

144 Short war-club, from ditto, curiously carved with a variety of forms and figures $2=-$

146 A piece of bark cloth, from Otaheite, and another from the

147 Ditto Friendly Islands

148 Sleeping stool, and salt dish, Otaheite

149 Beak of a pelican, part of the ribs of a seal, and the horn of a rhinoceros

150 Basaitic adze, Sandwich Islands

151 A fine mottled purple fluor, sprinkled with spathose iron

152 Stellated baroselenite, and lead, Wales, rare; iron ore, Germany; calcareous deposition on moss; black copper, Italy, \&c.

153 Two delicate varieties of purple fluor; sattin-like malachite, North Wales ; two marcasites, and another

154 Crystallized iron ore from a mountain in North Wales; gypsum, Severn; and tabular barytes

155 White lead in galena, Scotland; stalactitical iron ore in spar, Herefordshire; dark fluor", Durham; and three other minerals

156 Tin in large crystals, Cornwall; purple copper, and green arseniate of ditto, \&c. - six specimens $\varepsilon^{2}-6$, 1

157 Brilliant mundic, Ecton; denticular spar, and another $=3$

158 Rich sulphuret of copper, Snowdon; white gypsum, Sevc1.1 stellated baroselenite, and spar, both from Wales

159 Prehnite, Scotland; resin tin, fine; truncated galena, \&c. six specimens $\$$

160 Black manganese containing nigrillo silver, a delicate acicular spar, and a varietý of vitriolated lead

161 Nine small minerals, English and foreign-some rare

162 Tellurium, from Nagyag; two specimens of corundum, $E$. Indies; a jasperized iron ore, and a malachite carbonate - of copper

163 Eight curious ludii naturæ in flints, and an Egyptian pebble

164 Jasperified fossil wood, from Colserg; emery, from Turkey; porcelanite, Worcestershire, and three more

165 Dendrites in slate, from Florence ; serpentine stone, Tur-

55 key; a slab of dendritical bismuth, Saxony; a jasperified fossil wood, Colserg; and two gypsæ

166 A rock crystal, having curious internal appearances, a malachite copper ore, a large Scotch garnet, an Egyptian pebble, a barytes and an actynolite 
167 Octohedral green fluor, Devonshire; plated sulphate of barytes, Hartz; cubic and octohedral galena, Leicestershire; and a silicious iron ore os -

168 Green actynolite with quartz, Almaden in Spain; spar, in crystals of thirty sides each, Derbyshire; granulated iron ore, N.America; and a singular calcedony with quartz, spar, \&c. Palatinate

169 A scarce pecten, from Van Diemen's Land; a large parasol limpet, and a knobbed Arabian trochus

170 The stellated balanus, a. scarce white rhombus, and seven other shells 5

171 A large and fine spotted melon shell, from China

172 The conic bronze patella, an uncoated rugose sun, a lineated buccinum, and three others

173 The brown rayed satchel clam, a small tower of Babel, a scarce olive, and nine other shells

$174 \mathrm{~A}$ small spotted melon, an occidental argus porcelain, and a scarce winged shell

175 A Iris ear, a large tellina fausta, a rare purple gryphus and a scarce pecten, Van Diemen's Land.

176 The peppered, and another rare clam, a pheasant, and a waved emerald snail, Vin Diemen's Land, and two other shells

177 Fifteen fossils, plants, cone in cone corralloid, \&c.-various

178 Seven vegetable impressions; cast of a crab, Sheppy; and sundry other fossils

$178^{*}$ An iron nodule with two distinct impressions of fossil plants, a fern with elongated leaves, an impression of a rare bark with lozenge-form reticulations, \&c.-seven specimens

179 Four varieties of fossil plants; and impression of a tish, $E u=$ phrates $2=6$

180 Sundry fossils $a$

181 An uncommonly compleat impression of a fish, apparently of the clupea genus, with all tive fin rays visible, and skeleton, perfect-Papenheim

182 Very fair impression of the middle portion of a fish, from the Euphrates, and five other petrifactions

183 Impression of a fish, nearly compleat, from the former place, and a mass of turbinated shells

184 Vegetable impression in iron and coal slate

185 Ditto, various

186 A slab of gray slate, impressed on one side with reeds, and on the other, with a large sulcated bark-a capital specimen

187 A handsome group of white stellated coral 
188 Tubipora musica, isis hippuris, millepora muricata with the rudiments of red coral, madrepora gyrosa, \&c.-six elegant corals

189 Nautilus Pompilius

190 Turban echinus, violet spined ditto, lacunosus Penn, \&c.eleven specimens

191 Spondylus, spotted tun, small harp, and five other shells

192 A sole oyster, a clouded mitre, the lesser swamp club, and nine others

193 The loopard and panther needles, two screws, an uncoated ear, and a fan scollop

194 Lepas anatifera, the carved murex, the divided mussel of New Zealand, and eight more

195 A young leopard porcelain, Otaheite; a poached egg licium, ditto ; the tiger chersina, and a mya arenaria

196 A scarce triplex, Nootka Sound; the shower clam, and ten other shells

197 The white variety of the European cepa, the black limpet, and seven others

198 The undulated volute, an armed scoop, and a pheasant snail

199 The spider's web cone, a scarce trochus, and seven others

200 The rasp cockle, a scarce purpura, a bason tellen, and six others

201 A scarce orange buccinum, a rare mussel, one valve polished, and the great ear shell

202 The tawny, and two other rare species of bats, and a young opossum, from Louisiana

203 The red-faced parrokeet, the bird

204 The red barred toucan, from S. America, rare

205 The paradise tanager, and two other rare birds

206 The Jackamira, from Cayenne; and a chequered woodpecker, Louisiana

207 The manura superba, from New S. Wales

208 Tufted duck, male

209 Alauda magna, yellow-breasted lark, $\mathrm{m}$. and fem.

210 Great crested grebe, young

211 Lesser weasel, and anotber -3

212 Large brown American rat, and another 3

213 Shear-water petrel, Scotland

214 Thick-kneed plover

215 Red-breasted twite

216 A pair of pink-mouth alatx. and a large trochus

217 Cock-wing clamp, spotted melon, and another

218 Red and white spondylus, rare; nutmeg cowry, bat volute, and three other shells 
219 Furbelowed clamp; carinated murex, New Holland, and a snake

220 Long-spined spondylus, bat volute, nutmeg cowry, \&cc.twelve specimens

221 Fourteen limpets, various, some scarce

$222 \mathrm{~A}$ beautiful and perfect madrepora

222*The painted limpet, the Quaker helmet, and a many-ridged cardium, New S. Wales, a rare colus, and two other shells

223 A large Arabian trochus partly uncoated, and a sulcated sun shell

224 The spotted and another distaff, a black club, a bishop's mitre, the brown ark, and a mussel

225 Two scarce ears, two rare cones, and five other shells

226 The cinnabar scollop, two cardia, and three others

227 Cardium muricatum, rhombus despectus, a conic bronze limpet, and six others

228 Nine varieties of alavaster, from Tuscany; and two other gypsæ

- 229 Crystallized native sulphur, from Spain; native oxyde of manganese with crystailized quartz and schistose mica, Scotland; and a crystallized yellow copper ore, Stafford. shire

230 Dendritæ on laminated marl, Florence; a granatine, from Tortono, in Italy; and a polished fluor, Derbyshire

231 Crystallized carbonate and phosphate of lead; asbestos, from Bamffshire; a cockscomb pyrites, Derbyshire; and an Egyptian pebble

232 A pair of slabs from a beautiful fortification-like agate, and a silicious fossil wood

233 Antimoniated galena with spar, Leicestershire; steel-grained galena rich in silver, Halkin Mountain; ruby copper, Cornwall; mica in spar, Altenburgh; \&c.

234 Shorl in spar, Germany; iridescent galena in octohedral crystals, vitriolated lead in an iridescent matrix, green fluor with copper, \&c.

235 Clear yellow sulphate of barytes, in prisms; delicately crys. tallized white lead, Scotland; and foliated iron ore-all fine

236 Sulphuret of tin, containing according to some, native tin, Cornwall-very rare; elastic bitumen, rare; and ruby copper with green malachite

237 Salmon-coloured spar formed on pointed spar of a golden hue, very uncommon, North Wales; amber, Suffolk; and ruby copper, Cornwall

238 White lead in fasciculi, Scotland; black hæmatite iron, Germany; columnar spar, Somerset; and three more 
239 Native sulphur in the matrix, Spain ; native and ruby copper, Cornwall; serpentine with amianthus, North Wales; \&c. \& - 6

240 Galena in cubes, blend with pearl spar, and galena with cauk

241 A handsome polished slab of encrini marble, Derbyshire; and ditto of labrador

242 Fine dark green emerald fluor, Cornwall; oxyd of copper and phosphate of lead, Scotland; and amethystine quartz

243 Brilliant peacock foliated iron, Elbe

244 Jet-like fossil wood imbedded in grit-stone, and intersected

244* Topazine sulphate of barytes, in aggregated crystals, a fine specimen

$245^{*}$ Stellated baroselenite partially coated with oxyd of iron, rare? Wales; sulphate of strontian, Monmouthshire; blend on quartz, \&c.

216* Six small minerals, prehenite, Scotland; iron, Wales; tin in quartz, arseniate of copper, and green.phosphate of lead

with veins of galena : a singular and scarce mineral, and Scotch Hebraic granite

245 Lithanthrax from the coal mines of Hesse, extremely rare; and grey silver ore, Saxony

246 A very fine carbonate of copper, crystallized in stellated fasciculi of a fine green colour, Bannat

247 Reticulated millepores, and anomiz in limestone, Dudley; a mass of spiral fossil shells, from Austria : parts of encrini, Derbyshire; fossil plants in coal, Stourbridge; and a large echinus

248 Peritified fossil wood, Whitly; a fish's head in marl, $\mathrm{Pa-}$ penheim ; two reverse whellks, a nadrepore with cry'stallized quartz on it, \&c.

249 Various fossil shells, an echintis pileatus, some joints of encrini, teeth, and other parts of fishes, \&c.

250 Seven curious fossil plants, from Northumberland; \&c $\&$

251 A fossil fish with rhomboidal scaies in black slate, from $I s-$

* leben; and a skeleton of a fish in yellow laminated marl, Papentieim

252 Highly phosphorescent blue and green fuor, Aberdeenshire; rich cinnabar, Almaden; hornblend, New Casille; a porphyry, and two others

253 Crystals of feldspar, from Carlsbad, Bohemia; plumose silver ore on rock crystals, Freyberg; green actynolite, Scotland; and a gypsum, Deriyshire

254 Two of the Pietra di Coba, or poison suckers, E. Indiesvery rare; a rock crystal wit!, hair-like titarium inclosed, and another with curious internal appearances, Brasil 
255 A large and fine slab of the iridescent feldspar, rich in a va. riety of colours, from Labrador

256 The great ear, from Van Diemen's Land, and a Chinese window shell

257 A scarce terrestrial shell, from S. Carolina; a large rosarium, a triangular buccinum, and nine others

258 The aculeated cassidula, two alatæ, and three other shells

259 The Cape horn variety of the unicorn scoop, the sad scoop, a scarce variety of the spotted clam, and six other shells

260 The lesser oriental mother of pearl shell, one valve uncoated, and a large fresh water mussel

261 Two clubs, the scarlet pecten, from Guinea: and nine others 262 Cochlus singularis, and a scarce pectunculus, New S. Wales; a beautiful variety of the plough alatus, and a group of balani

End of the Second Day of Appendis. 


\section{THIRD DAY.}

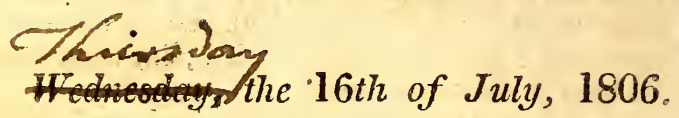

$261]$ HE duck's foot and another scollop, an oriental oyster, and three other shells

262 The lizard rhombus, from China

263 A polished silver-bronze limpet, a waggon road scoop with a number of serpulæa adhering, and four other shells

264 The purple fluted mussel, Straits of Magellan; the pallid rhombus, New Zealand; a mulberry trochus, and three other shells

265 The ridged trumpet, the tiger chersin, and an unccated trochus

266 A telescope and a Hercules's club, mytilus pictus, and three other shells

267 The ramose triplex, a scarce alatus, and two others

268 Cardium Elicum, a beaded fig, a bat volute, and three others

269 Calamine coating calcareous spar, both partially decompoed, Flintshire; red zeolite, Scotland: amethystine quartz, in a nodule; and green carbonate of copper, Montgonery. shire

270 Flesh-coloured gypsum, Severn; octohedral ruby copper, and another

271 Iron in stalactites, Monmouthshire; violet quartz, in agate; singular calcareous spar, formed in a nodule, \&c.-six specimens ?

272 Solid ore of nickel, green nickel, flesh-coloured gypsum, Monmouthshire; tessalated galena, and four others 
273 Beautiful pearl spar, Hartz; silky carbonate of copper, Bannat ; lava, Eitna ; and curious calcareous spar, Derbyshire

274 Native copper in spar, Siberia, rare; sulphate of strontian, Bristol ; and two others

275 Tin, Cornwall ; garnets in the matrix ; rock crystals sprinkled with pearl sjar; black shorl in quartz, Switzerland

276 Prehnite, Scotland; chalcedony in stalactites, copper, \&c. - six minerals

277 A slab of pudding-stone, polished, Herefordshire; ditto landscape marble, Cottam; a singular concentric marked ferruginous stone, Bohemia ; bloodstone, and a small septarium :-

278 A large slab of polished labrador

279 Grey native silver in calcareous spar, Hartz; white carbonaté of lead, Scotland; and garnets in a mieaceous matrix, Etna $2-6$

280 Curious dendritical marble, Germany; two serpentines, and three other polished stones.

281 Red stellated antimony, rare; green and purple oxyd of copper, Durham ; and pearl spar, Cumberland

282 A small slab of flexible sandstone, Brasil; green quartz in brown mica, New England; and prehnite.

283 Twenty-four sided purple fluor, Cornwall-rare; green

$2-3$ fluor on white quartz, ditto; and blend, Cumberland

284- Rich bubbled copper, Cornwall ; green phosplate of lead, Scotland ; and elastic bitumen in the matrix

285 Looking-glass copper ore, Germany, scarce; well-defined truncated cubic galena, Derbyshire ; brilliant octohedral galena, and bright purple blend on grey fluor, with bevelled edges

286. White quartz with marcasites, and ditto with pearl spar-two large specimens

287 A large crystallized specimen of a curious variety of yellow sulphate of barytes

288 Spar on stalactitical iron, North Wales; rich copper with cubic fluor, Cornwall; veined galena in spar, and two more

289 Black oxyd of manganese, beautifully crystallized, Aberdeen; violet quartz. \& c : 一 five specimens

290 Yellow calcareous spar very delicately crystallized, Hartz

291 Carbonate of barytes, Scotland-rure ; finely coloured topa zine sulphate of barytes; iron ore, Wales; dark green arseniate of copper, \&c. - eight small specimens

292 A large polished slab of fortification agate, Oberstein; ditto of labrador, and denticular spar

293 Harmastone, Scotland; green oxyd of copper, \&\&. 
294 Bright green fluor, Cornwall ; antimoniated galena with octoedral crystals, Leicestershire; and blue spotted carbonate of copper, Durham;-all fine

295 Six varieties of elastic bitumen, Derbyshire-rare

296 Green phosphate of lead, lead-hills, iridescent galena, briIliant calcareous crystals and another 3

297 Green shirl with mica, Tryol - a capital specimen

298 Stellated baroselenite, North Wales-rare; fluor sprinkled with pyrites, galena, \&c.-five specimens

299 Solid green malachite, Siberia-very fine

300 Nine minerals, various

301 Bones in spar, two varieties, Gibraltar, and other petrifactions

302 Vegetable impressions, various

303 Ditto

304 Singular regetable fossil barks

305 Echini, and various other petrifactions-some rare

306 Belemnitæ, vertebral joints of fossil alligator, \&e. 3

307 Sundry curious petrifactions 3

308 Beautiful vegetable impressions

309 Stems, fossillized barks, and other vegetable remains

310 Various fossils, several uncommon

311 Clear impression of a fish resembling the weaver Calliony. mus, found by Mr. Dawson on the banks of the Euphrates

312 A very fine vegetable impression of a ramose plant, with re. ticulated bark

313 Singular green shirl with hornstone, Sweden; green shirl in mica, Tyrol; amethystine quartz, and another

314 A choice specimen of green plumose copper, Bannat; and columnar crystals of yellow barytes

315 An uncommonly rich peacock iron with a bronzed bubbled surface, and cinnabar; and a fine specimen carbonate of barytes

316 Velvet iron, South Wales; sulphate of strontian, \&c. - five specime.1s

317 Tungstein, Bohemia-very rare

318 Singular gypsum in argil, Monmouthshire ; stellated baroselenite with lead, Wales-fine and rare; yellow sulphate of barytes, and another

319 Beautiful bubbled pearl spar with double pointed crystals of quartz, Hartz; cubic fluor coated with calamine, Flintshire ; silvery mica, Scotland ; \&c.-twelve specimens

$320 \mathrm{~A}$ fine piece of flos-ferri, Steurmark; topazine barytes, and three others

321 Green and purple cubic fluor; zeolite, Scotland; galena on chert, Aberiswith; \&zc.-six specimens

323 The marbled and gold-mouth snakes, an egg cockle, two grey thorny woodcocks; and four other shells 
324 The iridescent oyster corroded by boring mytili, from Anamaboo ; and a ramose triplex

325 A large and fine green and pearly snake shell, from China

326 The coronated and orange clouded needles, an American mytilus, and two other shells

327 Millepora foliacea on its native rock; madrepora tibicina, from Sicily; and a tubipora musica

328 Mya truncata, pecten marmoratus, a polished margaritifera, and three others

329 The long mussel, from Barbary; polished; and a young Arabian spindle shell

330 The serrated Venus's heart cockle, chiton olivaceus, a furlowed rhombus, the lesser French horn, and two other rare sheils

331 Cone in cone corralloid, Wales; septarium marble cut and polished, and three more

332 A delicate and pleasing group of rock-crystals intermixed with blend, Hungary ; green oxyd of copper, Scotland; and calcareous stone, containing silver, Germany

333 Fine grey stellated antimony; white gypsum, Severn; peacock copper, ruby copper, and another

$3 \hat{3} 4$ A polished slab of grey marble replete with sparry casts of shells of the ammonite genus

335 A beautiful specimen of cock-comb iron, North Wales; and another of Bristol celestine, or blue sulphate of strontian

336 Yellow phosphate of lead; slickenside, or looking-glass spar; peacock sulphuret of copper, Cornwall; and another

337 A large and fine specimen of dark green mica with shorl, and spar, Altenburg

338 Green and red serpentine with amianthus, North Wales; fluor, and vitriclated lead

339 Green copper, in hexagonal plates; Cornwall ; pink gypsum, Monmouthshire; sulphate of strontian, sattin spar, and two more

340 An elegant cabinet specimen of flos-ferri ; elegantly crystallized green oxyd of copper, Scotland; chalcedony, Cornwall, \&c.

341 Flesh-coloured gypsum, rare : fine crystallized oxyd of cobalt, two spathose irons, \&c. - six specimens

342 Dark cubic fluor, internally sprinkled with marcasites-a beautiful group

$342 *$ Velvet iron ore, rare; beautiful stellated green arseniate of copper, Cornwall; radiated baroselenite, rare, \&c.- - eight spacimens

343 Black iron ore, in feldspar, Germany; native copper, Siberia; white lead Scotland ; \&c.-eight specimens

$344 \mathrm{An}$ interesting series of asbestos, as in bright green serpen. tine, Wales; in dark serpentine, Scotland; cross-grained 
asbestos, America; fasciculated, Bohemia; white sattinlike, Corsica, \&xc.

345 Singular spotted stone, Aleppo; basalt, carbonate of barytes on blend, \&zc.-six specimens

346 Platina; rich grey silver ore, Germany; peacock copper, prehnite, native copper, \&c.-ten specimens

347 Plated grey iron with reticulated surf; ce, rare; figured granite, Scotland; arseniate of copper, fluor, with bevelied at the edges, \&z.-eight specimens

348 Witherite, Scotland; crystallized chromate of lead; fine ochre, Canarvonshine; and three others

349 Zeolite in basalt. Scotland; lead with calamine, singular blend, on octoedral galena ; gypsum, Wales; native cop. per, \&c.

350 Egyptian pebble exhibiting a lusus head, beautiful green marbled agate, antique ditto, and other polished stones

351 Stellated beroselenite, finely crystallized, Wales, rare; native cinnabar, Idria ; native copper, Cornwall, \&c.

352 Resin-coloured tin in large crystals, rare, Cornwall; trihedral blend, on cauk; sattin spar, and five others

353 Adamantine spar, East Indies, rare; elegant tabular barytes, Bohemia; garnets, bastard opal, and a variety of other small minerals

354 Elbe iron. crystallized-a specimen of uncommon beauty

355 Native gold in a group of crystallized quartz, Brasil; a capital specimen

356 An uncommonly fine specimen of topazine sulphate of barytes, crystallised in prisms, very rare in this perfection

357 Green phosphate of lead, beautifully crystallized, Scotland; emerald fluor, in while quartz, Cornwall; antimoniated lead ore, and blue oxyd of copper in sand-stone

358 A fine spccimen of Cook's comb iron, N. Wales; and amethystine quartz, Palatinate

359 Crystallised mundic, in truncated cubes; peacock lead ore, on white quartz, green fluor, on ditto

360 Three rare snails, and other small scarce shells, papal volute, harp, and a variety of other shells

361. Pinna ingens, Venus chioxe, and various other shells

362 Turban echinus, East Indies; rare purple spined ditto, two scarce placenta, and three others

$363 \mathrm{Zig-zag-lined} \mathrm{clamp,} \mathrm{scarce,} \mathrm{a} \mathrm{fine} \mathrm{orange-mouth} \mathrm{alatus,} \mathrm{and}$ a spider strombus

364 Sixteen species and varieties of the cypræa genus, some scarce

365 A fine oriental triplex, pied inulberry harp, bantled nerit, and two other shells

366 The hammer oyster; pulo condore 
367 Venus heart cockle, rare; a scarce spondylus, and two ringed snails

368 Chana hippopus, or bear's paw clamp, East Indies, a scarce tuberculated alatus, and a spotted cowry

369 An elegant stellated madrepore.

370 A group of balani, two senecti, and three other shells

371 A large moor rhombus, and an A:abian spindle shell

372 A pheasant snail, a South Sea snake, and four others

373 Section of a large spotted melon, and a young conch

374 A scarlet pecten, a lantern buccinum, and fourteen others

375 A large fan pecten, with adhesions of two species of serpula, a young zebra alatus, and two others

376 A vice admiral, and another rare cone, the pottle whelk, and twenty-two other shells

377 A scarce senectus, the cimnabar scollop, and a pyramid trochus

378 A dolphin, the furbelowed rhombus, the denticulated whelk, and three others

379 A group of serpula semi-muricata, with adhesions of other species of the same genus, and a large partridge tun shell

380 Eight various impressions of fossil plants in argillaceous iron ore, coal slate, \&c.

381 Bones of the head of a fish in marl, Sheepy Island; and two skeletons of fishes in yellow laminated marl, one with dendritæ, from Florence

382 A group of lepas tintinnabulum, a scarce variety of the antique purpura, and four other shells

383 A magpie, partly uncoated, a zigzag scollop, and a spider shell

384 Various species of diadem, and other echini, spines, \&rc.

385 A grimace, and a muricated buccinum, an egg cockle, and three others

386 The Chinese window shell, and a black hanmer margaritifera

387 Pennatula phosphorea, and various species of asteria, \&c.

388 The coronated melon, rare; the tiger chersin, and an iris ear shell

389 The giant indented oyster, from the Friendly Islands

390 The undulated volute, and a pheasant snail, with its operculum, Van Dieman's Land, and a beautiful polished bronze limpet

391 Two large specimens of cobalt in baryte

392 Compact zeolite, rose-coloured calcareo $^{\mathfrak{u}_{\mathrm{s}}}$ spar, and four others

393 Crystallized cobalt, looking-glass ditto, and steel-grained ditto

394 Adularia in basalt, grey copper ore, and four others

395 Four various specimens of cobalt, Hesse 
396 Sundry specimens of coal, exemplifying the ligneous stracture, and a singular crystal of gypsum

397 A capital specimen of brilliant crystallized grey cobalt with copper nickel

398 Native gold, Hungary; zuby silver, Hartz ; and seven other small minerals

399 Rose-like gypsum, Hesse; and cyanite, Tyrol

$400 \mathrm{~A}$ fine crystallized and fortification-like cobalt

401 Two specimens of crystallized quartz, Bristol ; and garnets" imbedded in mica, \&c. Spain

402 Steel-grained cobalt, looking glass ditto, and four others

403 A large specimen of calcareous spar, and four others

404 Pink and brown oxyd of cobalt, and brilliant arsenial pyrites

405 Schaumerde, Hesse; calamine, cobalt, and grey copper

406 Dendritical nickel, with green oxyd, and dendritical cobalt

407 Oxyd of nickel, ditto of cobalt, and grey copper

408 Crystallized cobalt, Saxony ; and oxyd of ditto, from Hesse

409 Crystalized uranite, ruby silver, and ten other small minerals 410 Black oxyd of cobalt

End of the Third Day of Appendix. 


\section{FOURTH DAY. \\ Tir.tom \\ Thurstefs, the 17 th of July, 1806.}

411 A Balanus with an oyster adhering, section of an alatus, and three other shells

412 Two uncoated iris snails, a yellow grimace, five othershe lls and a hermit lobster in its cell

413 Cardium costatum, the pied American scollop, a spondylus, and three others

\$14 The pigeon's egg bulla, the footman buccinum, and eighteen others

415 The Arabian spindle, and another, in a young stage of growth

416 A boat limpet, the flame clam, the undulated cone, and six others

417 An uncoated S. Sea snake, the purple-mouth alatus, a group of scarlet serpulæ, New Zealand; and three other shells,

412 Phosphorescent blue and green fluor, Aberdeenshire; sulphate of lead, Anylesea; cystallized native oxyd of tin, Cornuall; and a singular spar

419 Dendritæ on yellow laminated marl, Papenheim; ditto on flint, Norfolk ; iridescent feldspar, Labrador; and a red jasper, Saxony

4. Trey cobalt ore, Cornwall; galena in truncated octohedrons; Derbyshire; shorl in quartz, from Valencia in Spain; and three others

421 Tabulated sulphate of barytes, with crystallized quartz and pyrites, Hartz; schorlite, Saxony ; sulphuret of lead in deeply truncated cubes, with crystallized blend, Cumberland; and a yellow copper ore, with pyrites and quartz 
422 Grey silver ore with galena, Suxony; blue feldspar, Steurmark; a red feldspar, a septarium with pyritical septæ, and two others

423 Crystallized iron ore, from Elle; striated gypsum, Nottingham; cubic fluor with blend, Derlyshire; and a polished stalactical spar with undulated veins, same county

424 Crystallized Acantican with quartz, Arendahl in Norwvay, rare; needle-like sulphuret of antimony, Hungary; and stellated zeolites, frón Iceland

425 Part of a fossil fish, and a fossil lobster, Sheepy. Island; a belemnites, a gryphites oyster, a mass of shells in limestone, Austria; and another, with fragments of encrini, Derbyshire

426 Eight various impressions of fossil plants in argillaceous iron ore

427 Black and resin-coloured tin, Cornwall; calcareous spar, curious, Hartz ; cockscomb iron ore, Wales, \&c.

416*Amianthus, North Wales; green carbonate of copper, and hæmatite, Colebrooke Dale. 2

417 * Stellated lead and baroselenite, Wales-rare; cockscomb iron ore, ditto, \&c. $\cdots=2$

$418^{*}$ Singular stalactitical chalcedony, Cornwall; purple bubbled copper, ditto; and three other minerals 2

419*Vitriolated lead in clear white crystals, Anglesea ; native copper with maliachite; mica, and six other specimens

$420 *$ Pale rosy spar, crystallized on denticular spar of a golden hue, Wales ; tery curious magnêtical iron ore, America ; and three other minerals

421 *Yellow baroseleniter white calcareous spar with reddish. surface, Herefordshire ; fluor with rich metallic gloss, \&c.

$422 *$ Beautiful agate, Italian marble, ammonitæ, \&c.-five spe-; cimens

$423 *$ Ten minerals, rarioins; tin, galena, sulphate of barytes; \&c.

424*Delicately crystallized white lead, Scotland: stalactitical iron with spar, Wales; fluor, vitriolated lead, $8 \mathrm{c}_{i}-\operatorname{seven}$. specimens

425* Antimony in prisms, Dauphiny, fine 3 , 6

426 * Rich iron ore with a beautiful and extremely delicate plushlike surface, Wales, rare 3.2 .

$427 *$ Delicate heath-like spar, Glocestershire ; an onachine bastard opal; 'Hungary ; rich yellaw copper, blend, \&c.

428 Red crystallized chromate of lead, rare; solid calamine, Scotland; hæmatites iron ore, and two others 30

429 White lead ore beautifully crystallized, and galena in truncated cubes

430 Wavelite, Devonshire; radiated baroselenite, green arseniate of copper, sulphate of strontian, \&c-nine specimens 
431 Tepazire sulphate of barytes, pitch-like iron, pearl spar, i.... \& kc.- seven specimens

432 Barytes crystallized in tables, Germany; carbonate of baii... rytes, Scotland; native cinnabar on limestone; striated calamine, Wales; and four other minerals

433 Native cinnabar, Ilfeld; hacked pearl spar, Germany; amethystine fluor, and three others

434 Thirteen small minerals, containing compact basalt or touchstone; staurolite on amethystine quariz; whinstone, Coromandel; and elastic bitumen

435 A variety of small minerals

436 Thirteen interesting small minerals, phosphates of lead, malachites three varieties, manganese, tin, \&c.

437 Large group of cubic fluor in small crystals, partially coated with marcasites

438 Delicate plumose gypsum, Matlock

439 Large cube of purple fluor coated with rock crystals, two varieties of blend, copper, Scc.

440 Three Sweedish iron ores, and three others

441 Four varieties of sulphate of strontian

442 Sundry mochas, \&c. cut and polished; and two cut specimens of the Leverian sardonyx

443 Native oxyd of quicksilver, so rich as to yield 80 per cent. from Idria; topazine sulphate of barytes, Surry; and a mass of quartz pebbles cernented together by oxyde of iron, from Switxerland

444 Crystallised galena with a beautiful iridescent surface, Derbyshire; Hebraic granite, Scotland; crystallised mispickel with native oxyde of tin, \&c. Cornwall; and native oxyde of quicksilver, from Idria

445 A large slab of grey feldspar, beautifully variegated with onachine spots of the brightest blue colour, from Lalirador

446 White and grey actynolite, from Tyrol; and sulphuret of lead in large cubes, slightly truncated and aggregated with foliated quartz, tesselated pyrites, \&cc. from Saxony

447 White spar in cfystals of 24 sides each, with cubic fluors, having bevelled edges, blend, \&zc. Derbyshire; cinnabar with iron ore and crystallized quartz, Chili in S. America; rich iron ore, New York; and a galena

448 Stalactitical zeolite, extremely scarce, from Ferro; and a crystallived manganese, Alcrdeenshire

449 Cinnabar with iron ore, quartz, \&c. Chili; malachites carbonate of copper; crystallised galena, rich in silver, Freyberg; and pearl spar on quartz, Hungary

450 Crystallized iron ore, from Elbe; and a beautiful blue and green carbonate of copper, \&c. Siveria 
451 A finely crystallised Saxon topaz; tourmaline, from ' $C \in$ zis lon; a cat $s$ eye, some Bohemian garnets, two agates, and a specimen of red native alum

$452 \mathrm{~A}$ mass of fresh-water turbinated and bivalve shells in iron ore, Sussex; joints of encrini in limestone, Derbyshire; an alated oyster, Oxfordshire; and an ammonites

453 A fine fossil fish with rhomboidal scales, in black slate, from Isleven in Germany

454 Piece of the building of the termites of Guinea, wood perforated by termites, from the same country; some niduses of Vespæe, and other insects, \&c.

455 Curculio Imperialis, and sundry other insects

$443^{*}$ Rose coloured calcareons spar in primitive rhombs $444 \%$ A fine crystallised red arseniate of cobalt $\neq-6$.

$445 *$ Dendritical nickel, rare 6 ?

446 * Looking-glass cobalt, with crystallised cobalt

$447 \% \mathrm{~A}$ fine specimen of crystallized solid grey cobalt

$418 *$ Rose-coloured arseniate of cobalt, and barytes having a veit of gold crossing it -6

449* A capital specimen of ligit purple fluor, having its edges curiously tinged with deep purple

$450 *$ Crystallized zeolite, two cinnabars; and six other minerals.

451 * Nine various minerals, including some fine and rare

$452 * \mathrm{~A}$ very finely crystallised grey cobalt, Hesse $-10 \mathrm{cons}$

$453^{*}$ Remarkably large and fine stalactites, Eham, Derbyshire $454^{\times}$Twelve various impressions of fish, \&x. in coal slate 455*'Three deal boxes containing sundry minerals 5 ".

$456^{\circ}$ Two Chinese Buprestides, and various other Papiliones, Phalænæ, \&c.

$457 *$ Various insects of different genera

$458^{*}$ Ditto

456 A fine specimen of jaspideous wood richly sprinkled witts minute quartz crystals, Swindon, Wiltshire

457 A variety of volcanic productions, from Vesuvius, $8 \cdot 0.2 ?-6$.

$458 A$ beautiful small specimen of Brasilian native gold in the matrix

$\$ 59$ Native cinnabar; yellow blend, Scotland; blue and green malachite, Wales; and three other minerals

460 A large piece of the landscape Cottan marble

461 Fine spathose black iron ore and two others

462 Aluminous stone with copper and galena, crystallized alum yellow blend, native cinnabar, \&c. - eight specimens

463 Black blend on violet spar, dark amethystine quartz speckled with red, gypsum, and another

464 Beautiful calcareous spar, dark cubic fluor sprinkled with marcasites, denticular spar; and stalactitical iron ore, Germany

465 A group of singular spar with apatite, Hartz; and octoe- 
dral galena frosted with double-pointed denticular spar, Leicestershire

156 Apatite with marcasites, Hartz; green malachite, iron, \&c. eight specimens

167 Noble opal, semi-opal, crystal of beryl, Siberia ; topaz, cat's eye, grey silver, quicksilver in cinnabar, \&c. - sixteen interesting minerals

468 A very fine specimen of dendritical nickel, Hesse-rare.

469 Vitriolated lead, a fine specimen of the iridescent kind, and double pointed denticular spar. $2-2$

470 A capital mass of pearl spar with trihedral blend, in large crystals

471 Malachite on ferruginous ore, white lead and selenite in galena, \&c.-six

472 Seventeen interesting minerals, among which are titanium, iron in crystals, Bohemia ; yellow, red, and white arsenic, elegant tabular barytes, Cremnitz; tin, \&x.

473 Octoedral ruby copper, Cornwall; dark cubic fluor with marcasites, and crystallised phosphate of lead

174 Capillary silver in the matrix; and a finely crystallised white lead

475 Ten various European fishes, curiously preserved on paper

476 A scarce pecten, from Van Diemen's Land; the spotted and partridge tuns, a Medusa limpet, an oriental oyster, and an ear shell

177 A fine iris ear shell, from New Zealand, uncoated and po2.7. lished

478 A mince-pye star-fish, a twelve-rayed and three other asteria, and a sygnathus hippocampus, or little sea-horse

479 The crimson-mouth chersina, a rare terrestrial shell, from Guinea; and a vase murex

480 'The mottled hound's ear margaritifera, from China-very scarce; the pitch solen, and a striated Virginian mussel.

481 The granulated, a new species of trochus; a scarce patella, and a pheasant snail, from Van Diemen's Land; the creamcoloured pectunculus, and two other shells

482 A small specimen of the great indented oyster, from the Friendly Islands

483 The lesser antique lamp, a curious and extremely. scarce terrestrial shell, (allied to Helix ringens Linn.) from Brasi

484 A fine voluta fluctuata or undulated volute, from Van Diemen.'s Land

$\$ 84 *$ A large and fine haliotis suberba, or superb ear shell, the pearly inside of which is finely coloured, from the Gallapagos Isles, in the Pacific Ocean-very rare

485. Nillepora foraminosa, or lace coral; a delicate specimen of millepora tubipora, and a singular variety of gorgonia 
pretiosa, or red coral-all from Sicily; and a tubipora musica, from Aralia

$485^{*} \mathrm{~A}$ singular water-bucket, formed of a cornuted helmet of extraordinary size, from an island in the South Sed

4?6 The Jackamira, and another rare bird

487 The orange-faced parrókéer, Lousiana; and the green certhia, rare, from Sandwich Isles

488 The spur-winged water-hen, from $S$. America-very scarce

489 The ivory beaked or great crimson crested woodpecker, from

489\% The scarlet ibis, or curlew from $S$. America

490 A very fine specimen of that curious bird the Menura superba, from $N e w S$. Wales

491 Cornuted ostracion, or trunk-fish, and another curious fish.

492 Toad, lophius fisb, and another

493 Wagtail, $m$. and fem. and redwing

494 Spotted necked turtle-d

495 Motacilla stapazina, buff-wheatears, Africa-rare

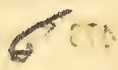

496 Shoveler duck 2 .

497 Summer titlarks, $m$. and fem. and another 3

498 Spotted fly-catcher, motacilla grisola

499 Weasel, and another

500 Cheshire grebe, female and young

501 Fifty specimens of sea-weeds disposed in six compartments, without frames-an interesting series

- 502 Eleven small shells chiefly of the voluta genus, some scarce

503 Madrepora fungites, a fine specimén

$50 \mathrm{r}$ Prince of Orange flag chersinæ, murices, an arca, \& $\mathrm{c}_{0}$ twelve

505 A pair of voluta cardinalis, ditto of the bat volute; and another, a scarce tuberculated alatus, and thres other shells

506 Devil's claw strombus shell

507 Seven impressions of curious fossil plants, in argillaceous iron ore and coal slate

$508 \mathrm{~A}$ long nodule of grey marlsplit in two and discovering the skeleton of a fossil fish imbedded therein, extremely curious and rare, from Greenland; and part of a fossil pentagonal asterias in chalk, from Kent

509 A beautiful red veined pebble, from the Palatinate; and a large and fine plate of oriental mocha stone

510 A variety of curious dried plants from New South Wales

511 Hammites, or roe-stone from Rutlandshire ; white actynolite, from Týrol; zeolite in trap, Isle of Sky; schorlite, Saxony; and two others:

512 Two beautiful oriental agates; and a scarce violet granite, from the East Indies 
513 Native quicksilver in glohules, on the surface of cinnabar, and native oxyd of quicksilver, from Idrin; and a specimen of stellated needle-like sulphuret of antimony with ba:oselenite, from Felsobania

514 Two very large and fine plates of oriental mocha stone

515 Three varieties of the Brasilian topaz, in their native form; a cat's eye, an oriental aqua marine, two Bohemian garnets, and a beautiful calcedony

516 A specimen of the iridescent feldspar of Labrador, rich in the most beautiful colours, and extremely vivid

$512 *$ Double horn of a rhinoceros

$513^{*}$ Remarkble long single horn of ditto

5:14* Pair of branched stag's horns, with singular brow-antlers

$515^{*}$ Horns of an antelope

$516 *$ Buffilo horns of uncommon magnttude

517 A Fine slab of flexible stone

518 A beautiful specimen of wood jasper

519 A fine Spanish avanturine

520 Three cut and polished specimens of the Leverian sardonyx

521 Nine beautiful varieties of arseniate of copper

522 Five crystallised tins, native arsenic, and three others

523 Crystallised uranite, iridescent blend, auriferous pyrites, and six others

524 Mispickel, lazulite, native gold, ruby silver, and four others

525 Crystallised tin and six others

526 Two specimens of native gold, calcedony, and oxyd of cobalt

527 Native gold, and three others

528 An extremely fine and perfect light-coloured impression of a fish in coal slate, Hesse

529 Hyalite, and eleven others

530 Lazulite, zeolite, and sundry others

53. Sundry minerals

532 A large and fine specimen of oxydated cobalt

533 Brilliant looking-glass cobalt, and black oxyd of cobalt.

534 Three various cobalts

535 Dendritical nickel and three cobalts

536 A beautiful specimen of rose-coloured and hrown oxyd of cobalt, Hesse

537 A lot of small minerals including uranite, \&zc. \&cc.

End of the Fourth Day of Appendix. 


\section{FETH DAY.}

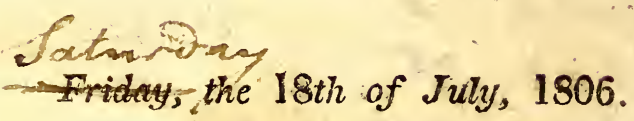

538 A Large German agate, jaspideous wood, and another

539. Aurum graphicum, native gold, and sundiy others

540 Sixteen specimens, including a series of cobalts, some very. fine

541 A variety of minerals $1-6$

542 A capital specimen of fortification cobalt, and pink oxyd of ditto 6 .

543 Looking-glass cobalt, and a fine crystallised ditto $/ 0$

544 Silvery selenite, and two fluors 4

545 Sundry minerals

546 Crystallised molybdate of lead and five others 2

547 Iron geodes, Nassau siegen, and two others

548 A beautiful purple fluor, and a yellow ditto

549 Two curious dendrites, and two others

550 A capital specimen of brilliant solid grey cobalt

$545^{*}$ Beautiful pale fluor, frosted with twenty-four sided calca reous spar, Derbyshire 3

$546 *$ Stellated antimony on white quartz, Felsobania singular tin, in shorl, rare, Cornwall; and brown spathose iron partly coated with smoky spar, Germany 2

$547 *$ Barytes in tabular crystals, purple fluor, and pearl spar coating denticular spar, Hungary 2.6

$548 *$ Rose quartz; grey copper, Curinthia ; and ruby copper $u$ al

549*Garnets in micaceous matrix, Mount Etna; mammillated iron ore with crystallised surface, Herefordshire; and plumbago, Cumberland $2 \%$ 
$550 *$ Large portion of an angulated asterias in chalk, having the outer margin, and three processes nearly perfect, rare, Kent ; and two scarce mammillated echini, in chalk 551 Fossil wood, coral, shells, and sundry other petrifactions / ? 552 Remarkably large and fine impression of a striated fossil bark, and a compressed reticulated stem, with part of the pith remaining 13

53 Petrifactions, various

554 Bones in spar, Gibraltar; petrified wood, variety of echini, and other fossils $1-6$

354*Remarkable vertebral bones in Papenheim marl; impres sion of a fish, ditto; mammillated echini; and part of an asterias in chalk, Kent-rare $5=6$

555 Delicate mammilllated and plumose green and blue mala. chite, Voigtland; amethystine quartz in agate, and black shorl

556 Occellated agate, Palatinate; a handsome group of rockcrystals frosted with pearl spar, and quartz with plumose copper

557 A choice specimen of crystallised iron ore, Elbe ; and cryse tallised sulphate of barytes of a fine topazine colour $2 \mathrm{WH}$

558 Plumose fasciculated white lead, and selenite, N. Wales, rare

559 Iron ore with a rich velvet-like surface, Wales-rare; red zeolite, Dunbarton, scarce; yellow calcareous spar, and green fluor 2

560 Seven minerals various

561 Hexagonal plated spar coating rock crystals, fine, Hartz 3 ?

562 Flesh-coloured double-pointed rock-crystals with mica, in 5 we!l-defined hexagonal plates; and purple fluor, Bohemia

563 Singular oriental onachine agate, E. Indies ; fortification agate, Palatinate; lapis sanguineus ; and two more polished

564 Twenty-seven various exotic fishes

555 The hare globe fish, and the mud fish, from Brasil, both rare

566 A variety of shells of different genera

567 Mytilus discors, and ditto in the byssus, from New Zealand; a. golden sun, the rayed trochus, and eight other shells

568 The rasp cockle, a spondylus, sundry other shells, and two shell spoons 8

569 The brown Venus's ear, the pigeon's egg bulla, a vice admiral, the cat's paw spondylus, and sixteen other shells $\%$

570 The wampum clam, (Venus mercenaria Linn) section of an A rabian spindle, and a pecten grandis

571 The Moor rhombus, a small Nereid's trumpet, and thirteen other sheils $3-6$

572 Mytili with fuci, from the Cape of Good Hope; the bidentated lamp snail, a rare cardium, and six others 
573 An oriental lepas, the unicorn scoop, an acaleated frog, - balanus tracheosus, rare; and eight others

574. A:fine melon shell $9-6$

575 Mytilus Cygneus, a group of tintinnabulum, balanus com5 munis on woud, mactra lutraria, and various other shells

576 The g!anulated trochulus, New. Zealand - trochus tuber, the sanded cone, and twelve others 7

577 A magpie, uncoated, a large limpet; and a leopard porcelain shell a sitary

578 Conus nebulosus and hepaticus, a stair case, the white Verius's ear, and eleven others' $a-b$

579. The filleted scoop, a bishop's initre, section of ditto, and six others $9-6$

580 A large duck's foot scollop, a spirler strombus, and another shell $\&=6$

581 An oriental mother of peal sheh, one valve polished, two pectens; section of an alatus, and four others 3

582 The Prince of Orange's flag chersina, the footman buccinum, and ten others $1 y-6$

583. A large Nautilus Pompilius, partially uncoated $/ 0-6$

584. A small spider strombus, the ruddy centated oyster, a painted clam, and six others $/ 0$

585 Cyanite, Alps; solid sulphate of barytes; and micaceous schistus, Scotland $5=8$

586 Frankenburg copper, shirl, and two others pe 4.

587 A group of calcareous spar in dumble pointed hexagonal crystals; and white lead crystallised, Scotland 2.

588 Stalactitical calcedony, Cornwall; silver-grained lead ore, galena with white lead, \&c. $=$

589 Tiwenty small minerals including staurolite on blead, manganese, Germany; tin, copper, lead, \&c,

590 Donax trunculus, two suns, a brown caterpiliur club, and eleven other shells

591 The puiple spondylus of Sicily, and the hollow-ridged cockle / 6

592 The long-beaked fig, a rayed mask, a purple gryphus, and six other shells

593 Two wrinkled clubs, twg-South Sea snakes, the thick clam, and ten others.

594 The Chinese window shell, a square pane formed gat of a larger one; a polished clam, and three others $\%$

595 The yellow seal's paw, the Holland flag chersina, a lepas anatifera, helix janthina, and eight others 7.7

596 An arca nox, a poached egg licium, and fort others

597 A French horn snail, an uncoated emerald suail, and seven $6-6$

598 Section of a needle, a polished bronze limpet, and four others 9

599 A large polished magpie, a group of balani, and a pecten 4

600 Three curious Chinese ornaments; a mother of pearl govget, Otaheite; a fish hook, Nezi Zealand, \&c. 5 -6 
601 The occidental music, section of ditto, a spotted distaff, mulberry trochus, and two needle shells

602 The cinnabar scollop, the cock's wing clam, an uncoated margaritifera, and a panther porcelain shell

603 Chama calyculata, the bleeding teeth nerita, section of the hair-streaked cuma, and nine others $6 \neq 0$

604 The long Barbary and striated Virginian mussel, one yalve of the first polished, and a scarce thorny woodcock

605 Madrepora cyathus on a scarce millepore, Sicily; the annulated madrepore, and red organ corals, and a piece of a ship's keel perforated by teredines

606 Venus Dione Linn. an uncoated trochus, section of a volute, a scarce bulb, and five other shells 1

607 The variegated spondylus, from China; and a fine zebra trochus

608 The brunette cockle, a harp, a striated fig, and six other shells

609 A many furbelowed clamp, a polished silver bronze limpet, and the yellow variety of the fan scollop $13-6$

610 The black hammer margaritifera, and a polished pectunculus

611 A scarce balanus, the sieve clam, a rare pecten, section of a cone, a brunette porcelain shell, and an oyster 3

612 A small spotted melon, a Chinese harp, a group of balani, and a leopard porcelain shell

613 The fluted green dentalium, the violet mouth hystrix, a scarce reversc lendix, chiton olivaceus, and two others

614 The umbilicated variety of Nautilus Pompilius, partly un. coated, a striated cone, and the camp olive shell $/ A$

615 Solen radiatus, the painted mussel, one valve polished, and a Venus's heart cockle

616 The singular sea snail, from New S. Whates; and a rare cardium, fiom the Friendly Isles

617 A scarce triplex, from Japan; a knobbed rhombus, China: and a spiked alatus

618 A very large Neptune's Trumpet shell, (Murex Tritonis, Linn.) elegantly marked, and of the richest colour-from Otaheite. Such fine exemplari of this species are extremely scarce

619 Dendritical native gold, Hungary; grey silver, ditto; black stellated manganese, and arseniate of copper

620 Two trays containing asbestos, amianthus, asphaltum, and various other minerals

621 Ditto, containing selenite, and various others o

622 A pleasing variety of small specimens, including Brasilian native gold; ditto, Hungary ; uranite, \&c. $15^{\circ}$

623 Septaria, Isle of Sheepy; and various others

624 Steatite, Cornwall ; and four singularly shaped stones

625 Three curiously formed scoria from furnaces 
626 Various minerals

627 Porcelain earth, Saxony ; red asbestos, asphaltum, and sundry others

628 Three various cobalts, and green oxyd of nickel

$6 \% 9$ Two trays, containing sundry specimens of apparently volcanic productions, from Devonshire

63 , Various small polished specimens of Java; steatite, Saxony; (terra miraculosa) and sundry others - in two trays

631 Dendritæ on sandstone, and a variety of orbicular pyritæe, \&c.

632 Double orbicular sparry formation, Finland; asphaltum, Trinidad, \&c. 4 -

633 A fine specimen of fortification cobalt

634 Salt, beautifully crystallized on the branch of atree

635 A handsome slab of Florentine marble 6

636 Steatite, Cornwali ; dendrites on sandstone, \& $\mathrm{rc}_{6} /$

637 Three remarkably shaped stones :

638 A variety of mineral bodies 2

63 Copper nickel with green oxyde, artd a cobalt

640 A fine double orbicular sparry formation, Finland; septaria, \&:c

64? Fibrous selenite, and sundry others $l$

642 Three various cobalts, and dendritical nickel /

643 Sir fossil echini, and three others

644 Asphaltum, Dead Sea; looking-glass cobalt, manganese, and sundry others

645 Large dendrites on sandstone, and various others

646 A mass of fossil wood, and another

647 Fossil shark's tooth, Malta; and six others

648 Fossil antenna of a lobster, and three others

649 Fossil bones of tortoise, Sheepy; and three parts of fossil crabs

650 Nine curious fossil weeds of a o $1-0$

651 A beautiful impression and the counterpart of a fossil fish, Verona

652 Three curious sponges, millepore, and three corals

653 Two fine branches of the purple Gorgonia setosa. The

654 A capital specimen of Venus' fan, or Gorgonia flabellum

655 Fair of horns 7

656 Sundey ditto $4=4$

657 Curious double horn of the rhinocergs 56

658 Antelope's horns, a large pair

659 Horns, a singular lusus

660 Sundry ditto 20 ,

661 Horns of the Arné, a noble pair

66\% Contorted borns $2=4$

663 A lucus cluster of three horns of a ram 2

664 Ram's horns of uncommon size?

655 Horns of a stag

666 Twisted horns, curious 
667 Fair of ditto of the American moose

668 Horns, various

696 Ditto

670 Large pair of horns

671 Ditto

672 Ditto

673 Ditto, sundry

674 Ramose horns

675 Ditto, curious

676 Very large horns of an antelope $3-6$

677 Stag's horns 10

678 Ditto 8

679 Ditto

680 Ditto

681 Ditto

682 Horns of the ammon

683 Horns, curious 40

684 Ditto

FINIS。

Printed by George Hayden, No. 4,

Brydges Street, Covent Garden. 



\section{catalogue}

\section{OF THE \\ LEVERIAN MUSEUM,}

INCLUDING

THE THPEE IAST DAYS SALE。

The present Publication, comprizing the Three Last Days' Sale of the Leverian Museum, has been completed and printed previously to those parts which would follow in connected order, for the purpose of making known to distant collectors, some of the leading rarities of this Museum. At the same time it is proper to remark, that care has been taken, not unduly to enrich the three last days' sale at the expence of the days preceding : the magnitude and richness of the Collection, afforded ample means of attaining this nbject.

It is imagined this portion of the Sale will take place about the middle of June, 1806.

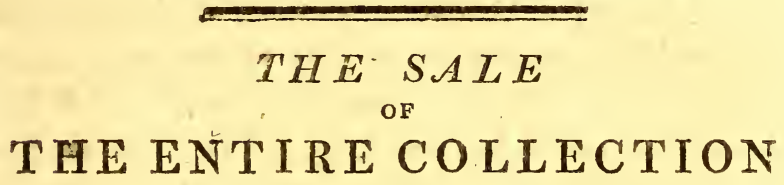

(By Messrs. KING and LOCHEE,)

WILL COMMENCE

On Monday, the 5th of May, 1806, at Twelve o'Clock, In the Building now occupied by

THE MUSEUM.

The two Parts of the Catalogue already published, (Price 1s. 6d.) to be had at the Museum; at Messrs. King and Lochêe's, (the Auctioneers) and at Hayden's Printing-Office, Brydges-Street, Covent-Garden.

Hayden, Printer, 4, Brydges Street, Covent Garden. 


\section{CONDITIONS OF SALE.}

1. THE highest Bidder will be declared the Buyer; but if any Dispute should arise, the Lot must be put up again.

II. No Advance less than Sixpence; above One Pound, One Shilling; above Five Pounds, Five Shil LINGS.

III. Every Purchaser is to pay down Five Shillings in the Pound, as Earnest, in Part of Payment, and to give in his Name and Place of Abode, if required.

IV. The Lots to be removed, at the Expence of the Purchasers, within one Day after the Sale; and. the Remainder of the Purchase-Money to be paid on or before the Delivery.

V. Upon Failure of complying with the above Conditions, the Money deposited in Part of Payment shall be forfeited. All Lots uncleared within the Time aforesaid, shall be re-sold, oy public or private Sale; and the Deficiency (if any) attending such Re-sale, shall be made good by the Defaulters at this Sale.

Gentlemen who cannot attend the Sale, may have their Commissions faithfully executed, by their humble Servants,

King and Lochée. 


\title{
LAST DAY BUT TWO
}

\author{
OF
}

THE SALE.

- 4- 6 1 Powner horn, America, curiously carved by the Indians

2 Remarkable stirrups, Barbary

- Y - 3 Flaming sword, and a Persian dagger

4 Moorish criest

5 Singular three-bladed weapon, supposed to be African

6 War club, Caledonia; ditto, Friendly Islands; and a patapattoo

7 Elegantly inlaid Persian gun

8 African bow and arrows

1,5

10 - 9 Large and handsome flax mantle, Nootka Sound

Lye 10 Remarkably handsome four-pronged spear, twelve feet in length, Friendly Islands

1-9-11 Curiously ornamented high conic cap, Nootka Sound. The pattern of this cap exhibits the processes of the whale fishery, and is particularly noticed in Cook's voyages

D. 8 - 12 A very large and capital Chinese gong

$-12613 \mathrm{~A}$ large and fine specimen of millepora alcicornis, with a star-stone and other curious adhesions

14 A specimen of the brain-stone madrepore of gigantic magnitude, weighing upwards of $2 \mathrm{cwt}$.

- -15 A large group of madrepora flexuosa

16 The broad flat variety, with slender short branches of madrepora muricata, East Indies, a fine specimen

17 Antipathes spiralis, large and fine specimen 

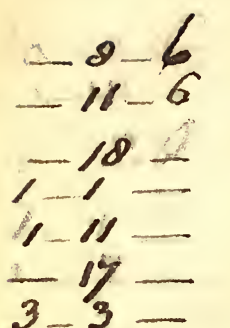

$3-3$

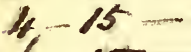

$26 \ldots 10$

$2-2$

$1=15$

$1-2$
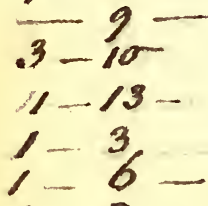

$1-2$

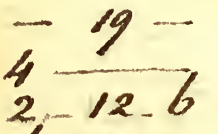

6.10

$\frac{1}{19}$

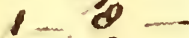

$1-\infty$

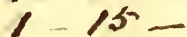

2.13

$25-3$

10

政

2

2
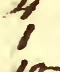

$10-10$

$1-3$
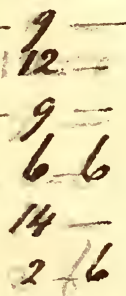

18 A remarkable variety of madrepora carduus, or thistle coral

19 Millepora cellulosa, lace coral arfixed by its natural base to an - anomia terebratula, a delicate and curious article

20 Madrepora verrucosa, warted coral, East Indies

21 Cuckoo, (three specimens) cuculus canorus and corvus frugilegus, nı. and fem.

22 White variety of cuckoo, cuculns canortus

23 Fasciated grosbeak, loxia fasciata, Gmel

24 Rough-billed pelican, Pelicanus trachyrinchos

25 Nicobar pigeon, Columla nicolarica

26 Golden eagle, Falco chrysuetos, Linn.

27 Cuculus Persa, Linn. tauraco bird

28 Virginian horned owl, Strix Virginiana

29 Snowy owl, Strix nyctea

30 Starling, $\mathrm{m}$. and fem. Sturnus vulgaris

31 Secretary vulture, Vultur Secretarius, one specimen without case

32 Sparrow hawk, m. and fem. and young, Fulco nisus, Linn.

33 Wild swan, Anus cygnus, ferus

34 Gambo duck, Surinam, Anas casarcn

35 Rain cuckoo, Jamaica, Cuculus vetula

36 Common quail, common cross-bill, Loxia curvirostra, m. and fem. and nagpie, Corvus pica

37 Albatross, Diomedea exulans

38 The king vulture, vultur papa, without case

39 Large head of sea cow, trichecus rosmarus

40 Hyrax capensis, very rare

41 Moschus Leverianus, sive delicatulus, very rare

12 Bat, Madagascar, Vespertilio Vampyrus

43 Siberian jerboa, Dipus Jaculas, Gmel. vare

44 Ursus Liascus, the glatton or wolverene

45 Leopard, felis leopardus

46 Tyger, felis tigris

47 Long-tailed Pangolin, Manis tetradactyla, very rare

48 Simia syluicola, dog-faced bajoon, very rare

49 Flying colngo, galcopithecus volans, extremely rare

50 Ursus Polaris, the great white Polar bear, and cub

51 Ovis Ammon, Musnom of Gesner, Corsica

52 Two specimens of cornu ammonis

53 The impression of a fish in incurated marle, from Florence, an uncommonly fine and well defined specimen

54 Two specimens of cormu ammonis, an impression from Colebrook dale, and a fussil madrepora

55 A gigantic specimen of the striated pecten, Bristol

56 Cast of an ammonite coated with spar; another, shewing part of the peayrl coat of the shell; and a third in pyrites

57 A large mass of teredines, singularly grouped, Gloucestershire 
$-4-658$ Two very curious impressions in laminated slate, from $\mathrm{Pa}$ penheim; one of them a shrimp, the other a crab

39 Impression of a large fossil in dark slate, shewing several joints of the vertebræ, and some of the ribs, Gloucestershire

1/ - 60 Head of the lily encrinus, Brunswick; part of another, Derbyshire; and large shark's tooth, Malta

$6-61 \mathrm{~A}$ fine specimen of asterias, in chalk, with part of the body and one of the rays nearly perfect

-10.6 62 A large and fine angulated turnip, Providence

17 - $63 . \Lambda$ fine and large specimen of the purple-ringed trochus, from Nootka Sound, very scarce

12664 The endive purpura of a large size, Manilla; the purplemouth alatus, Florida; and an armed scoop, Friendly Isles

3.3 - 65 The butter-fly wing, or Guinea admiral cone, conus Germanus, Linn. two inches and three quarters long, Guinea, very rare

-13 - 66 The hare alatus, rare; and two fine olives

3 - 67 Great swallow margaritifera, mytilus hirundo, var. Linn. China-rare

4an- 68 A single valve of the chama gigas, from Borneo, in length

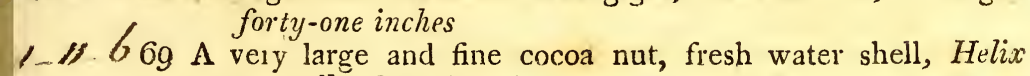
ampulla, from Dominique

is 70 A large undulated helmet, West Indies; and a large bull'smouth helmet

- 9 - 71 Two of the orange-mouth olive, South Sea; and a black music, from Guinea, all large and fine

2 - 73 A large conus aulicus, Amboyna, rare; and a very scarce rhombus, East Indies

1_ 74 The magician cone, another of the same genus, and the horned cassidula, (buccinum trames, Soland.) all very rare

_. furbelowed whelks, Nootka Sound, all rare and fine

1-2 - 76 A fine wrinkled distaff shell, from Tranquebar, very rare

3_3 - 3 77 A large and fine yellow chersina, and a beautiful reverse ditto, undulated with brown, both from Prince's Island, and rare

4.5 78 A very large beaded mitre, (voluta scabriuscula Linn.) from the Friendiy Islands, rare

2. 2 - 79 A large and fine carved variety of the black hounds' ear vulsella, Leuconia, very scarce

( -80 The white scorpion purpura (Murex Scorpio, var. Linn.)

- 80 The white scorpion purpura (Murex Scorpio, var. Linn.)
extremely scarce

81 The tiger cone, rare; a fine dolphin, and the false high Admiral cone 


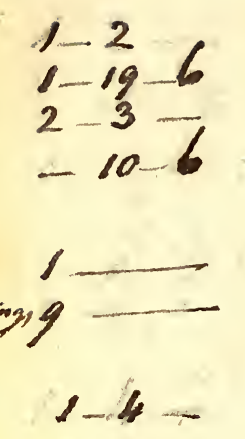

82 The great brown melon, (voluta pesso) Guinea fine

83 A large and fine devil's claw Strombus, Madagascar

84 A large and fine banded grey olive, Trançuebar; a fine camp olive, and a singular variety of the bat volute

85 A small spondylus hystrix, China; the tree oyster, West In. dies ; grey cockscomb oyster, Molucca Isles; and a scarce gryphus

86 Conus gracilis, the slender cone, Japan; very rare

87 A most beautiful variety of the painted nerita, having three rich pink bands on a dark clouded ground, taken from an ornament worn by a native of one of the Sandwich Islands-very rare

88 Conus latruncularius, the draught-board cone, (conus zonatus) Nicobar Isles-very scarce

$5-5$

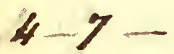

$33-12=$

25

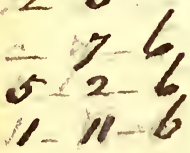

$29-$

20
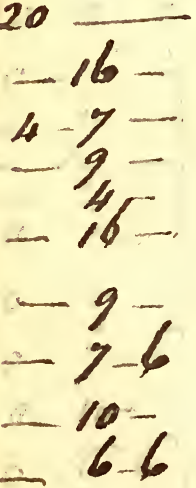

89 A very fine and complete Venus' comb, or double thornywoodcock, (murex tribulus Linn.) China-very scarce,

go A large and fine voluta nobilis, or noble volute, from China -very rare

91 Gigantic elephant's tusk, weighing 113 th

92 A very fine and compact mass of brilliant crystallized gray cobalt, Hesse

93 Black hæmatites, iron ore, Saxony

94 Native iron, Siberia, very rare

95 Spicular red copper ore, in quartz, Germany

96 A large and fine specimen of sattin-like green copper ore, formed of capillary filaments of a close texture, reflecting beautiful appearances, with a little ochre intermixed, from Tourtschininow, near Uralgeburg Siberia

97 An extraordinarily large and fine specimen of mountain crystal, Switzerland

98 Antimony, on tabular barytes, Transylvania

99 Native knitted foliaceous goid, Transylvania

100 A capital specimen of black stalactitical iron ore, from Triers

101 Very fine specimen of black hæmatites, Triers

102 An interesting specimen of gold, crystallized in minute octohedrais, on a quartzose matrix, intermixed with galena, Transylvania

103 Crystallized mica, in quartz, a fine specimen, Siberia

104 Part of a large crystal of clear selenite, Hungary; and large crystal of ditto, Oxfordshire

105 Beautiful specimen of delicate red and yellow clay, whence unknown

106 Glanzerde, or shining calcareous earth, from Rubitz in Saxony; together with a small medallion, the surface of which is rubbed over with the earth

107 Group of small crystallized selenite, and part of a large crystal of ditto, Oxfordshire 
6. 108 A large rhomboidal selenite, Oxfordshire; and specimen of asphaltum, from the Asphaitum Lake in Trinidad

2 - $\log A$ very large mass of cubic salt, crystallized round the surface of a basket, which was left in a Pond in salt Island, near Tortola, the specimen is 59 inches in circumference

5 - 110 Various specimens of asbestos, and amianthus, in a glass case

- 111 A very handsome Etites, or eagle stone

112 Dark coloured dendritæ, on laminated sandstone, Lancashire

113 Beautiful light-coloured dendritæ, on laminated sandstone, Lancashire

10 114 Keffekil, or meerschaum

- 7115 A fine specimen of mountain leather, Siberia

\$ 6116 Very large arrow-headed selenite, Monte Martre

4- 117 Clear white selenite of extraordinary size, Scotland

6- 118 Dendritical native gold, from Potosi, uncommonly rare

4. 119 A calcareous deposition of most striking beauty coating
the cavernous sides of an agregate stone, and tinged of a
delicate purple colour, from the cobalt mines of Hesse

4. 119 A calcareous deposition of most striking beauty coating
the cavernous sides of an agregate stone, and tinged of a
delicate purple colour, from the cobalt mines of Hesse

4. 119 A calcareous deposition of most striking beauty coating
the cavernous sides of an agregate stone, and tinged of a
delicate purple colour, from the cobalt mines of Hesse - extremely fine and rare

$15120 \mathrm{~A}$ most curiously formed and admirable group of the aquamaxine, (beryl of the ancients) in its native state, being

60 ire an hexagonal truncated columu, coated with ferruginous ore, from Nestchinsky in Siberia

\section{(1)} mous ore, from Nestchinsky in Siberia

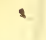




\title{
LAST DAY BUT ONE
}

0

\author{
THE SALE.
}

\begin{abstract}
$10-6$ a $\mathbb{M}$ EAT-DISH, Otaheitee
$10-2$ War-club, $N$ America

$1-15$, 3 War-club, Caledonia; ditto, Friendly Islands

7-6 4 Jarge sleeping-stool, Otaheitee

5 Beautifully carved war-club, Friendly Islands

6 Large painted Chinese fan

7 Singular Oriental musical instrument

$8 \mathrm{Jdol}$, New Zealand, curiously carved in beautiful green Nephritic stone, or Jade

$4-4=9$ A large and elegant vase of Persian ware

$4-14-6$

10 A very large dish of ditto

2. 3 .

11 A large and extremely curinus female head, sculptured in basaltic stone, from the celebrated cave of Elephanta, near Bombay

23 - 12 Remarkably large and handsome breast-plate, made of dog's

13. 613 Piped wirey-sponge, West Indies; and a branch of gorgonia

3. 14 Serpula filosa, Mediterrncan; netted coral, millepora reticu-

lata, ditto; and coralina officinalis

4.15 Bone of the gorgonia flabellum, completely coated with millepora alcicornis, or elk's horn coral, West Indies

2 - $15-16$ A curious specimen of the netted corai, Millcpora reticulata,

$6 \quad 17 \AA$ most delicate and perfect specimen of the lace millepore, affixed by its natural base to a fragment of coral, serpula, \&c.

$2 d-9-6$
\end{abstract}


3. 6 18. Gorgonia verrucosa, gorgonia flabellum, and a coral

- 19 A very complete and elegant specimen of madrepora gy= rosa

5. 20 Gorgonia verrucosa, Mediterranean, a large specimen

21 A very large specimen of the tubipora musica

//. 622 A large branch of madirepora muricata, Linn. prickly white cural, from the West Indies

6-23 Very curious variety of madrepora fungites, Linn. or seamushroom, remarkable for having twenty young ones of the same kiud formed on its under part, East Indies-such specimens are very rare

19- 24 A large fossil mya shell, Oxford

25 Fossil elephant's grinder, found near Warwick

26 Part of the fossil tusk of an elephant, ditto

1) $27 \mathrm{~A}$ large knobbed species of strombus, in the fossil state, France

28 Bone of a bird, in laminated calcareous stone

29 The section of a cornu ammonis, filled with spar, an elegant specimen

30 Pectens, three species, one obliquely striated and uncommon

31 A large fossil cornu ammonis

32 Two sections of a fossil nautilus, in limestone, polished

$11-6$

33 Three different species of pectens, and a flattened ostrea

34 Three specimens of fossil sisells, including part of a cham-

bered nautilus; and another, with many ridges compressed

212636 Two sections of a fossil nautilus having the chambers filled with spar

16 36 Four fossil shells, including a cockscomb oyster; valve of ostrea gryphites, with a curious impressed beak, part of a pinna, and an ostrea

$2 \ldots, 37$ The upper part of a large thigh-bone fossil

38 A specimen of cornu ammonis, Gloucestershire

39 Four fossil shells, including a murex, Italy; cast of the interior part of an echinus, Gloucestershire ; a cone, and another

2. 10. 40 A very large fossil elephant's grinder, found in England, (a printed description annexed)

1341 Peregrine falcon, falco peregrinus

16 42 Wryneck, tunx torquilla, $m$. fern. and young

2. I 43 Blossom-headed parrakeet, Psittacus rhodocephalus

212644 Poe bee-eater, Merops cincinatus, rare

2.3 45 Demoiselle crane, Ardea virgo

2-4 - 46 Pied hornbill, E. Indies, Buceros bicornis, very rare

/-g. 47 Red-headed grosbcak, Loxia regulus, extremely rare

2.2 49 Common hen and chickens, beautifully preserved

3-5 49 Cupreous cuckoo, Senegal, Cuculus cupreus, extremely rare

121250 Phasianus licalcaratus, peacock pheasant, China, a most beautiful specimen, very rare

1851 Quan, West Indies, Meleagris cristata 
$4-4$ - 52 Bird of Paradise, Paradisea apoda

2 13 53 Velvet-shouldered peacock Japan

110.54 Wattled stare, Sturnus carunculatus

$\begin{array}{ccc}16 & 55 \text { Pin-tailed duck, m. and fem. Anas } \\ 3.4 & 56 \text { Alpine vulture, vultur percnopterus }\end{array}$

// 57 Belted kings-fisher, Alcedo alcyon, m. and fem.

1 . 58 Black swan, Anas Plutonia

21 - 59 White jerfalcon, Falco Gyrfalco

$12 \ldots 60$ Flamingo, a singularly fine and high coloured specimen,

3. 15 Phcenecopterus ruler

3.1561 Chimera monstrosa

23 ti2 Short sun-fish, Tetrodon mola

1- II - 63 A large saw-fish, Squalus pristis

7. 64 Lacerta Crocodilus, 13 feet in length

65 Raja manatia, demon ray, a very large and fine specimen, West Indies

15 66 Pleuronectes ocellatus, South Seas

67 A large and fine specimen of Lacerta Chamaleon

68 Five-toed Pangolin, manis pentadactyla

$6 \quad 69$ Galliwasp, Jamaica near the Coast of Caba

$211-71$ Lion, felis leo, mas.

s 73 Rhinoceros, young, Rhinoceros Unicornis

74 Elephant, Elephas maximus

1. 1075 Head of buffalo

$2.10,76$ Head of Ethiopian boar, Sus Ethiopicus

414.677 Ursine sloth, Bradypus Ursinus, without case

, $y$ - 78 Antilope, Antilope albifrons

79 Sea otter, Nootka Sound, Mustela lutris, a most capital specimen

$3 \ldots 5-80 \mathrm{~A}$ highly interesting and perfect specimen of the Oran Otan, Simia Satyrus exiremely rare

// _- 31 A very large and fine Wentletrap, (Turbo scalaris Linn.) two inches and three quarters in length, Sumatra, very scarce

1-14 - 82 The reticulated grimace, China; rhombus via nontana, Tranquelar; and the orange long-beaked trumpet, $\mathrm{Am}$ loyna-all fine and rare

2 - $53 \wedge$ large and fine argonauta nodosa, or tuberculated paper sailor, Brasil, rare

84 'The mottled hound's ear margaritifera, Friendly Isles, very rare

3-5. 85 Rhombus porcatus, the ridged rhombus, whence unknown, extremely scarce

3. 3- 86 The Japanese crown melon, very scarce, Japan

$1-13$ - 87 The unicorn scoop, from Falkind Islands; and a singularly formed dolphin, seä-snail, both of extraordinary size 
3- 88 The huntsman cone, South Sea; the brocade cone, China; both of extraordinary size, and a spotted tun

- 19 89 The orange-mouth spider, Amboyna, very scarce; and a rare swallow margaritifera, Pulo Condore

90 The great high admiral cone, two inches and three quarters in length, Friendly Islands, fine and very rare

1- 9 - 91 The violet echinus from China, very rare

3 15. 92 Haliotis grandis, the great ear, of extraordinary size, beiug seven inches and a half long, from Van Diemen's Land

156.93 The great, or giant oyster, Friendly Isles

17. 694 The great Oriental mother-of-pearl shell of an extraordinary size, China

1-2. 95 Cardium Costatum, or bollow-ridged cockle, from Guinea, rare, a large and fine specimen

2. 6- 96 Large dish of Raphael's ware

97 Ancient English battle axe

3. 13. 698 Ancient English breast-plate and helmet

minated the tomb of Confucius. This master-piece of ingenuity was pronounced by Mr. Cox, (the proprietor of the celebrated Mechanical Museum) to be " one of the most extraordinary productions of art ever beheld," and he moreover added, " he could not undertake to make one like it for a less sum than ${ }_{t} 1500 . "$ It is scarcely necessary to add that every spectator of discernment will find the proportions of the various figures (though so extremely minute) of critical accuracy. The lody of the performance is formed of double-gilt silver, which is richly ornamented with Syrian garnets, rubies, and diamonds.

- 19 - 100 Beautiful brown dendritæ on laminated sand-stone, Lancashire

9 101 Variegated Asbestos, formed on a coarse rock stone

106102 Delicate dendritæ on yellow laminated marble, from Sulenhofen, near Papenheim

13103 A fine and large specimen of bubbled galena

$1-16104$ A fine specimen of pure plumbago or graphite, weighing twenty-four ounces

$\checkmark$ G105 Solid tin ore, Cornwall : and octohædral tin ore, with yellow crystals of quartz

/ / - 106 A capital specimen of black crystallized columnar tin, Cornwall

A /3, 107 A large and finely crystallized specimen of resin-coloured tin, Cornwall

22108 A superb specimen of looking-glass cobalt, having its surface nearly over-spread by red arseniate of cobalt, with botryoidal and crystallized white pharmacolite, Hesse

168 109 A slab of the ultramarine variety of iridescent Feldspar of matchless beauty and perfection 

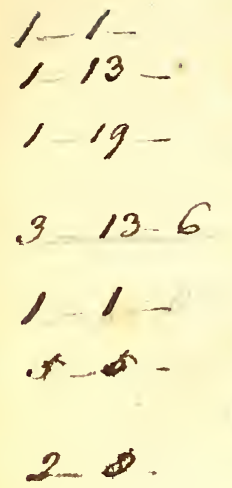

$0-9-0$ $4-15-$ 210

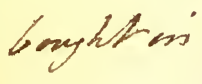

$23 /, 15,6$
110 Foliated native gold on quartz, Transylvania

111 A capital specimen of native foliated, and moss-like gold, Transylvania

112 Black hæmatites iron ore, from Triers, with ensiform crystallised manganese on the surface, an uncommonly fine specimen

113 A matchless specimen of brilliant gray crystalized cobalt, Hesse. The crystals are of most uncommon magnitude

114 Two crystals of aqua marine, one very perfectly formed and having the apex complete, Siberia

115 A cut specimen of topazine crystal, Brasil

$116 \mathrm{~A}$ most beautiful and capital specimen of stalactitical iron, the surface richly coloured, Germany

117 Crystals of topaz in a quartzose matrix, extremely well defined, Saxony

118 A single crystal of the Saxon topaz, very large and fine

119 Opal in the matrix

120 A capital, and for beauty and magnitude unique, specimen of the true Avanturine, weighing near 5lb. This curious article was found in the ruins of the triumphal arch of Julius Cæsar, in the valley of Suse in Piedmont, in 1788, by the Sieur Francis Ludwig, of Mayence. It takes a very high polish, and is much harder and infinitely more beautiful than the stone commonly known by the same name.*

* The artificial Avanturine has leen known for ages, specimens of it being frequently found among the antient ruins of Rome. Some eminent mineralogists have questioned the existence of such a beautiful stone as the natural Avanturine; but the following respectalle authorities put the matter beyond a doutt. They are translated from the originals and addressed to Mons. Ludwig of Mayence, from whom the specimen was purchased for two hundred guineas.

SIR,_ "The Quartz Avanturine that you have been so "s obliging as to let me see, merits, by its beauty, the utmost "6 attention of the amateurs. I have never seen one yet which " more resembles the artificial glass, known by the name of "Avanturine. I am, Sir,

Vienna, 12 th May, 1790. Your very obedient Servant, J. BORNE."

"I perfectly coincide with the sentiments of my " friend Mr. le Chevalier Borne, that it is a laminated ferrugi"s nous quartz, of the carnelion colour, abundantly impregnated with copper-coloured mica, which, by the intimate mixture 
"6 and the different position of the particles, appears to have pro-

"s duced the natural Avanturine.

Freylerg, 4th June, 1790.

De Charpentier."

"I have seen with the greatest pleasure the large, specimen of red-coloured quartz, mixed with mica, belonging to Mr. Ludwig, which throws great light on the true origin of " the Avanturine. It is an unique piece, both on account of " its size and beauty.

Cologne on the Rinine, 8th Aug. 1790. Baron de Hupsch."

"The under-signed attests never to hare seen a "s quartz mixed with mica, of such size and beauty. It is usually "c called Avanturine. Dr. Charles Henti Titius, Inspector of his $S . H$. the Elector of Saxony's Dresden, 9th July, 1790. Calinet of Natural History."

"As a zealous amateur of lithology, and possessor " of a sufficiently compleat collection, I think it incumbent "s upon me to declare that I never have seen an Avanturine of a "beauty so perfect, and size so uncommon, as that belonging to 66. Mr.'Ludwig, of Mayence. Dresden, 12 th July, 1790. JOSEPH FREDERICK, Baron of Racknitz."

"The under-signed acknowledges never to have "s seen so large and clear a quartz mixed with glimmer, which " so compleatly represents the composition known by the name " of Avanturine.

Vosmaer, Hague, 13 Sept. 1790. Director of the Calinet of Nat. Hist. of the Prince Stadtholder.

"In addition to the foregoing testimonies of the great judges in natural history, I must confess never to have of seen a production ir the mineral kingdom which has so much " excited my admiration, as this wonderful specimen, which I "s had the pleasure of seeing throngh my acquaintance with its "s proprietor, and which will be of great use, as adding to the "s discoveries in natural history. FRANCIS WILLIAM, Cologne, Aug. 5, 1790. Count of Otting, Baldern, E' Portern. Testor et Olstupea. F. WALLR AB, Professor at Cologne." 


\section{LAST DAY}

OF

THE S A L E.

- -9 $6 \times \mathbb{A A R G E}$ and handsome sleeping-stool, Otaheite

2 Curious club, New Caledonia; and a ditto, Friendly Islands

3 A remarkably handsome and beautifully worked war-club, Friendly Islands

4 Mask, made to resemble a bird's head, Nootka Sound

5 Curious wooden idol, S. Sea

6 I.arge feathered idol, Sandwich Islands

7 A large and perfect single canoe, Esquimaux

8 The identical superb feathered cloak and helmet, with which the celebrated Capt. Cook was decorated by the King of Owyhee, a short time previous to his assassination

9 Curious East Indian musical instrument

10 Large and curious sculptured head, from the cave of Elephanta, near Bombay

11 Very handsome Persian target

12 An uncommonly elegant specimen of cut paper, representing birds, insects, \&c.

.5 .15

13 A very fine and perfect dress of a chief mourner, Otaheite with the stick and clapper

14 Remarkably well-executed mask, in memory of a dead friend, Nootka Sound

15 Tyger cat, Felis pardalis, very rare

6 Long armed Gibbon, white variety, Simia longimana, very rare 
17 Coati mondi, young, two specimens, viverra nasita

is Bradypus tridactylus, three toed sloth, rare

19. Prehensile porcupine

20 Steinbock, Capra itjex, extremely rure

22 Hippopotamus, Hippopotanus amphilius

22 The Swedish elk, cervus alces, a capital and finely preserved specimen

23 Purple water-hen, Fulica porphyrio, S. America

24 Sparrow hawk, Falco nisus, Linn, and green parrot, S. America

13 - 25 Snow gulls, Hudson's Bay

26 Ultramarine thrush, Ampelis cotinga

3 - 27 Northern three-toed woodpecker, Picus triductylus, Linn.

28 An eminently fine and perfect specimen of the Argus pheasant, Sumatra, Phasianus Argus

29 Columba Nicolarica, Nicobar pigeon

30 Mandarine Duck, Anas galericulata, Linn.

31 Secretary vulture, Vultur secretarius, one specimen

32 Certhia cruentata, red spotted creeper

33 Red certhia, Sandwich Islands, Certhía vestiaria

34 A most capital and matchless specimen of the Vultur gryLo in phus Linn. being a full grown specimen of the male birc. in the highest preservation

34 The King vulture, Vultur papa

36 Silver pheasant $\mathrm{m}$. and fem. Phasianus nyctihemerus

37 'Tyger bittern, Ardea tigrina

38 Goatsucker, Caprimulgus crassirostris

39 Falco leucocephalus, the white-headed eagle

10 A very fine and well-preserved specimen of the female ostrich, a young ditto, and the egg, with the instruments used in catching these bircis

41 The male ostrich, a noble specimen

42 Part of a branch of Isis hippuris; dwarf variety of madrepora virginea, or stellated branched coral, from the West Indies; and another

43 Gorgonia pretiosa, the true red coral, on its native rock, from the coast of Sardinia ; a specimen of considerable magraitude, and singular perfection and beauty

44 One specimen of gorgonia pectinata, of Linnæus, the comblike gorgon, with a curicus asterias caput medusæ, intangled in its branches, from the East Indies

15 Part of the branch of a tree, pertorated by pholades, and hav ing its surface incrusted with groups of serpula filosa, Mediterranean

46 Isis hippuris, an extremely elegant and perfect specimen

17 Large and singular variety of madrepora labyrinthica, on sharp-ridged brain-stone, Martinique 
49 A group of serpula filosa, Mediterranean; and two specimens of lace coral

49 A large and beautiful specimen of the broad-ridged brainstone, madrepora sinuosa

50 A most superb tree of the red variety of Isis ochracea, or jointed red coral, East Indies, on its base are several curious adhesions

51 A large fossil nautilus, shewing much of the inner structure of its chambers, Sheppy Island

52 Bone of a bird in laminated calcareous stone, Oxfordshire

53 Fossil shoulder-blade-bone of some large unknown animal, Shotover Hill

54 A remarkably fair impression of a fish, in dark slate, Isleben

5.5 Section of a large cornu ammonis, the cells of which are filled with spar, an elegant specimen

56 A fossil nautilus of very large size, Sheppy Island

57 The bone of a bird partly incrusted in a slab of laminated. calcareous stone, Oxfordshire

58 A large and curious fossillized shell of the vulsella kind, retaining great part of the pearly coat of the shell, very fine, Maryland

$59 \mathrm{~A}$ fine and beautiful specimen of petrified wood, having one of its transverse sections polished, Colbourg, Saxony

60 A large fossil grinder of the mammoth, from the banks of the river Ohio, North America

61 The ridged orange striped helmet, very scurce; conus imperialis, and a groom cone

62 A small or dwarf strombus truncatus, or flat.spired stromb, South Sea

03 Conus magnus from Tranquelar ; the cancellated brocade cone, China; and a fine granulated turbo, from Nootka sound-all rare

64 The orange-strainer mitre, (voluta cribrum) the brown and orange banded mitre (voluta cingulata) and the hottentot mitre, (voluta caffra Linn.) - all from China and rare

65 The angulated tunnip, Florida, rare; and a fine tulip cuma, West Indies

66 A large and fine oliva incrassata, or thick-lipped olive, (voluta incrassata, Soland) from Brasil, extremely scarce

67 Nautilus Scrobiculatus, Soland. or umbilicated nautilus, New Guinea-extremely scarce

68 An exceeding fine spondylus aculeatus, or spiked hinged oyster, of a redish purple colour, Guinea-extremely scarce

69 A large and fine Midas-ear land-shell, voluta auris-Midæ, Malacca-very rare

zo A beautiful variety of the mammilated echinus, from China, very scarce

71 The long spired asterias, from the East Indies, extremely scarce 
g2 An exceeding fine alatus latissimus, or broad-winged strom: bus, Strombus latissimus, Linn. very rare, Amboyna

73 The hace-spined echinus cidaris, with its spines, from $S t$. Mauritius, vexy rare

74 A large and fine anomia sanguinẹa, or sanguineous lamp cockle, from New Zealand, extremely scarce, allowed to be the largest specimen known

75 A most beautifui tortoise-shell harp, buccinum testudo $S_{0}$ land. from Madagascar - the finest known

76 A very rare echinus of the clypeated kind, from the South Seas

77 The reverse variety of the high-spired turnip, from Madagascar, extremely scarce

78 Prince of Orange flag-music, (voluta arausiaca Linn.) from Amboyna, fine, and very rare

79 The morning dawn, or orange. cowry, cypræa Aurora, Friendly Islands, extremely scarce

80 The great orbicular echinus, from China, very rare

81 An clegant and unique pink variety of the imperial sun, drawn up with the anchor of a ship, from the depth of 60 futhoms, in Cook's straits, New 'Zealand

82 Papilio Ulysses, fine and rare, one specimen

83 Fulgora lanternaria, or great lantern carrier

84 Tettigonia australasiæ, Don. New Holland; cicada hœmatodes, both in the pupa and perfect state, another Tettigonia, and a blatta

85 Scarabæus Hercules, male and female, America-the latter very rare

86 A curious scarabæus, commonly supposed to be of the species goliathus, cetonia goliathus Fabr. whence unknown

87 Papilio Priamus, East Indies-very rare and in fine condition

88 A fine specimen of the phasma gigas, in its pupa state

89 Phasma dilatatum, a large and fine species. This specimen is presumed to be unique

$90 \mathrm{~A}$ most noble specimen of the fossil scull and horns of the - moose deer, from Ireland, the horns measure 13 feet from tip to tip

91 A specimen of mandelstein, or almond stone, the kernels consisting as it is supposed of native and oxydated lead

92 Magnificent specimen of calcareous spar in primitive rhombs, of a lovely rose colour, with louking-glass cobalt, Hesse, extremely rare and fine

93 An interesting specimen of mineralized wood, one part beins impregnated with silicious matter, and giving fire with steel, the other retaining its original combustible quality

94. A fine group of dodecahedral garnets, imbedded in a green 
micacous matrix, called by the Germans, schneidstein, from Mount Caucasus

95 A large oriental amethyst, polished, but uncut

96 A very fine columnar amethyst, from Siberia

97 A tine Brazilian topaz in its native crystallised shape, and a specimen of quartz, with prismatic colnurs

98 Cubical blue chalcedony, Hungary; and blistered copper, Cornwall

99 Iridescent iron ore, from Elbe, extremely fine

100 Chromate of lead, in large crystals

101 An uncommonly fine specimen of smoky rock crystal, exhibiting curious internal appearances, among which are many needle-like figures which have the form of complete and well defined crystals, supposed to be titanium

102 Native ramose copper, from Pokadeschky, near Uralgeburge, Siberia

103 Capillary native silver, from Potosi, extremely fine

$204 \alpha$ very large mass of prismatic Feldspath of Labradore, in which a combination of different tints of gold, crimson, blue, \&cc. variously blended in fine gradations, edged with a lively green, constitute one of the most beautiful and vivid assemblages that can be imagined. The colours pervade the whole specimen, which is judged to be the most capital of the kind ever brought from that country.

505 A snuff box made of lepidolite, handsomely mounted

100 Superb Ivory Cup, presumed to be one of the most exquisite works of the kind in Europe

Testimonial relative to the cup, given by Professor Thorkelin. "The ivory cup in the Museum, late Slr Ashton Lever's is an undoubted work of Magnus Berg, a Danish artist, who having been engaged in France, during the reign of Louis XIV. as Medailleur, returned home to Denmark, where he painted on the walls of Friedricksberg, the history of Christian $V$. and carved in ivory several cups, part of which still remain in the Royal Museum at Copenhagen; and others were made presents of to foreign princes, by his royal master. The life of this truly extraordinary genius, is inserted in the Danish magazine of historic knowledge, $174 \%$.

Magnus Berg died in the reign of Friedrick IV. who was succeeded by Christian VI. in the year 1730.

\section{G. T. THORKELIN."}

107 A qua marine, a very fine and perfect crystal

3080 p:1 in its matrix, a remarkably brilliant specimen

109 i magnificent Iave:, of the curious old Raphael's ware; the furm an elegant oval, with a'rccurved edge, and 
pointed bottom, which, as well as a raised zone or belt, which encircles the middle of the outside, is wrought in fluted or gadrooned work. Each side is ornamented with a laughing cornuted satyr's head. Two grotesque sphinxlike figures, half satyr, half dragon, with each a double tail, serve as supporters; their arms are extended to the edge, and their hind parts, with wings expanded, underneath, resting on an oval base, which has a hollow gadrooned edge. The whole is painted in the most lively colours, and glazed. On the inside, within a broad grotesque border, is represented a Roman naval engagement; the boarding of two ships by a number of soldiers in boats, sword and shield in hand ; sailors fixing their grappling hooks to facilitate the entrance of the assailants, who are opposed by soldiers on board the ships armed in like 'manner. The outside is enricher. with grotesque figures, supporting festoons of flowers, interspersed, among which are birds, military achievements, foliage, \&c. This capital and masterly performance bespeaks it the work of first rate genius, and renders it the deserved object of general admiration. It was originally in the Medicean Collection, and, at the time of the Duke of Tuscany's taking possession of that valuable repository, was, by mistake, put out, with other articles, for sale, and purchased by the late Admiral Broderick, for a considerable sum, on whose demise it came into the possession of the late Sir Ashton Lever.

110 A box formed of the Lumachelli marble, from Carinthia, the colours of which are uncommonly splendid

111 An exceding fine specimen of thread-like chalcedony, crystallised in the hollow of a piece of quartz, Germany

112 An elegant specimen of onachine agate, beautifully variegated with strata of Dove-colour, white, purple, \&c. from the Palatinate

113 Brilliant crystallized cobalt, Hesse

114 A most capital mass of rich oriental amber-coloured onachine chalcedony or Sardonyx, beautifully intersected by regular veins of pure opake white. The general structure is cavernous, and the surface mammillated or bubbled. This specimen which is csteemed to be wholly unrivalled, weighs nearly 224 pounds

\section{F I N I S.}










$$
378
$$


- 